\title{
INVESTIGATING THE EFFECT OF SEASONAL VARIATIONS, EXPRESSED BY MOISTURE AND TEMPERATURE CHANGES, ON SOIL SURFACE STABILITY USING PROXIMAL REMOTE SENSING
}





\title{
INVESTIGATING THE EFFECT OF SEASONAL VARIATIONS, EXPRESSED BY MOISTURE AND TEMPERATURE CHANGES, ON SOIL SURFACE STABILITY USING PROXIMAL REMOTE SENSING
}

\author{
DISSERTATION \\ to obtain \\ the degree of doctor at the University of Twente, \\ on the authority of the rector magnificus, \\ prof.dr. ir. A. Veldkamp, \\ on account of the decision of the Doctorate Board, \\ to be publicly defended \\ on Thursday the $27^{\text {th }}$ of May 2021 at 12:45 hours
}

by

Irena Ymeti

born on the $8^{\text {th }}$ of October 1979

in Skrapar, Albania 
This thesis has been approved by Prof. dr. F.D. van der Meer, supervisor

Dr. D.B.P. Shrestha, co-supervisor

ITC dissertation number 394

ITC, P.O. Box 217, 7500 AE Enschede, The Netherlands

ISBN: $978-90-365-5173-1$

DOI : $10.3990 / 1.9789036551731$

Printed by: CTRL-P, Enschede, Netherland

Cover design by: Irena Ymeti, J ob Duim (ITC)

Copyright @ 2021 Irena Ymeti, Enschede, The Netherlands. All rights reserved. No parts of this thesis may be reproduced, stored in a retrieval system or transmitted in any form or by any means without permission of the author.

\section{UNIVERSITY OF TWENTE.}

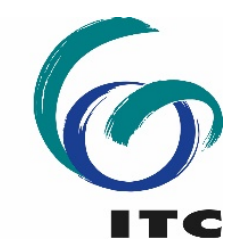


Graduation committee:

\section{Chairman/ Secretary}

Prof. dr. F.D. van der Meer

\section{Supervisor}

Prof. dr. F.D. van der Meer

\section{Co-supervisor}

Dr. D.B.P. Shrestha

\section{Committee Members:}

Prof. dr. D. van der Wal

Prof. dr. V.G. Jetten

University of Twente

Prof. dr. S.M. de Jong

University of Twente

University of Utrecht

Prof. dr. E. Garcia Melendez

University of Leon 
To my parents 


\section{Summary}

Soil is the outmost layer of earth that supports plant growth and many living creatures depending on it. Likewise, the soil is a natural body comprising of solids (minerals and organic matter), liquid, and gases that occurs on the land surface. Therefore, the soil is an essential resource that supports life on earth. It provides the only adequate environment for forest growth and crop production, securing human food supplies. Also, the soil is the medium that filters and stores the water and is a reservoir of carbon. Soil is the linkage between the atmosphere, hydrosphere, lithosphere and biosphere. However, the soil is subject to degradation as a result of natural and human factors. Indeed, extreme weather conditions such as prolonged droughts or extreme rainfall are often decisive for this phenomenon's stimulation. Moreover, the internal soil physical and chemical deterioration, steep slopes and the absence of vegetation cover affect soil degradation. Likewise, human intervention (e.g. deforestation, intensive cropping, overgrazing, forest fire, land-use change) can lead to soil degradation. We are constantly confronted with soil degradation, which involves the decline of the soil's physical, chemical and biological state. Furthermore, soil degradation weakens an ecosystem's capacity to function appropriately, affects the climate by changing the water and energy balances, and disrupts the carbon, nitrogen or sulphur cycles. Consequently, soil degradation may lead to increased runoff and soil erosion, pollution of natural waters, and greenhouse gases emission into the atmosphere.

Soil stability is defined as the aggregates' ability to maintain their bonds under stresses that might trigger their disintegration. Not only the soil properties such as soil particle distribution, mineralogy, organic matter content, cationexchange capacity, but also climate and land management practices affect soil stability. While we may understand the factors dominating soil stability, the spatial and temporal variations of these factors controlling the soil stability dynamics are still missing. Indeed, the soil stability changes through space and time are complicated because of the soil-climate-management practices interactions.

Since soil is not static, its moisture, temperature, amount of organic matter, cation exchange capacity (CEC), soluble salts and $\mathrm{pH}$ may fluctuate with seasons' change. The interactions between the soil minerals and organic compounds create mineral-organic associations, acting as binding and cementing agents in the soil. The inorganic constituents play a critical role in determining soil stability than the organic ones. However, there is limited knowledge of the soil mineralogical behaviour at varying temperatures and soil moisture contents occurring in a short period at the microscale. Therefore, it is necessary to capture the behaviour of soil properties for which the proximal imaging spectroscopy is an alternative since it can assess the spectral soil constituents responsible for soil stability. This technique allows acquiring quantitative soil data at the fine spatial, spectral and temporal resolutions. Moreover, it is rapid and measures several soil properties with one scan. The proximal sensing approach is also cost-effective and environmental friendly compared to conventional soil laboratory analyses.

Soil is a complicated matrix with high spatial and temporal variability. Soil stability is a result of complex interactions of the soil properties, climatic 
conditions and land management practices. Although these relations are recognised, it is not fully understood which soil properties or stresses are responsible for the soil stability alterations over a short period. Indeed, it is not easy to assess stability because the soil properties that control it change over space and time. It becomes complicated when the climate and management practices that affect the soil stability at the catchment scale are considered. However, this research is limited to investigating the soil organicmineral interactions at a micro-plot scale under laboratory conditions using imagine spectroscopy. The soil stability is affected by the capability of the aggregates to maintain their bonds under stress. Soil aggregation is a process by which aggregates of different sizes are joined and held together by different organic and inorganic materials. However, as a result of different stresses, the soil aggregates break down into finer particles. These micro-aggregates (20 $250 \mu \mathrm{m}$ ) affect the process of infiltration, crust development, surface runoff and interrill erosion. Therefore, it is essential to monitor and quantify the soil aggregates dynamics under the natural condition at the micro-plot scale.

The Visible Near-I nfrared (VNIR) imaging spectroscopy can assess the spectral soil constituents responsible for the organo-mineral interactions. These interaction mechanisms occurring naturally in the soil depend not only on the soil mineralogy and their reactive surface area, soil type and soil texture but also on the various moisture conditions (dry, field capacity and saturation (waterlogging)). However, there is limited knowledge of the soil mineralogical behaviour at different moisture contents occurring in a short period. Similarly, freeze-thaw cycles during winter months in the higher latitudes or the high mountain regions might encourage migration and alter the chemical constituents in the soil matrix exposed to different moisture conditions. As a result, the soil mineralogical changes occurring due to the freeze-thaw process triggering the soil mineral precipitation, dissolution and release might affect the soil aggregation. These alterations could be detected using the VNIR imaging spectroscopy approach. Therefore, the main research's objective is to investigate the seasonal effect on soil surface stability using proximal remote sensing.

The effect of soil surface mineralogy alterations due to moisture variations is one of this study's objectives. Soil samples were collected in the Netherlands, from (i) Limburg, where loess is the primary soil type and (ii) in Deventer, where sand is predominant. However, the Silty Loam soils are used to investigate the soil surface mineralogy alterations. The Silty Loam soils support a considerable variability of plant life because, in the silt particles, the organic matter content and soluble nutrients occur. Nevertheless, these soils are also susceptible to various environmental stresses. Therefore, the Silty Loam soil samples varying in organic matter content $(0 \%, 4.6 \%$ and $12.3 \%)$ and moisture conditions (dry, field capacity and saturation) are used. These soil samples are photographed using an imaging spectrometer camera for eight weeks under laboratory conditions at a micro-plot scale at 72 hours basis.

The Spectral Information Divergence (SID) was applied to detect and quantify (in percentage) the soil image area occupied by Mg-clinochlore, goethite, quartz coated $50 \%$ by goethite, hematite dimorphous with maghemite. The SID, an image classifier, is a probabilistic approach that uses the divergence measure to compare each pixel spectra with the reference spectra. If this divergence, which is related to a threshold, is small, then the pixel spectra are close to reference spectra. The results showed that the percentage of these 
minerals changed over time, depending on soil type and soil treatment. For the soils with organic matter, the mineralogical alterations were evident at field capacity state; for the soil without organic matter, these changes were noticeable at waterlogging-field capacity treatment. Using imaging spectroscopy data, the results showed that the Silty Loam soil mineralogy changes over time due to moisture variations.

Likewise, the effect of freeze-thaw cycles on the soil surface mineralogy at different moisture content was studied. The hypothesis is that the freeze-thaw process triggers soil mineral precipitation, dissolution and release. Silty Loam soil samples varying in the organic matter content $(0 \%, 4.6 \%$ and $12.3 \%)$ and moisture conditions (field capacity and saturation) are used. The soil samples exposed to freeze-thaw cycles are photographed using an imaging spectrometer camera for eight weeks in laboratory conditions at a micro-plot scale at 72 hours basis.

Using the SID approach, the soil image area occupied by Mg-clinochlore, goethite, quartz coated $50 \%$ by goethite, hematite dimorphous with maghemite was detected and quantified (percentage). The results showed that these minerals behaved differently under freeze-thaw cycles, depending on the soil type and soil condition. While the Mg-clinochlore, goethite and Qz-Gt behaviour depended on the presence of organic matter, the $\mathrm{Hm}$-Mh did not show such a dependence. The results suggest that the amount and the type of organic matter are vital in soil experiencing the freeze-thaw cycles. When the soil is exposed to the freeze-thaw cycles, the moisture conditions (field capacity or saturation) have a significant impact on mineral behaviour regardless of the soil type. The use of imaging spectroscopy data on the Silty Loam soil exhibited that the surface mineralogy changes over time due to freeze-thaw cycles, depending on the soil type and the moisture conditions.

It is vital to monitor the interaction between the soil surface and the surrounding environment at a high temporal resolution to understand these changes. Also, considering that data acquisition remains expensive and image analysis is often complicated and time-consuming, the possibility to monitor soil aggregate breakdown straightforwardly and cost-effectively was investigated. A digital camera mounted in a fixed setup enabled photographing the same location over time, acquiring time-series data. Next, the digital camera's capability to monitor soil aggregate breakdown was analysed in soils of different texture classes (Silty Loam, Loam and Sandy Loam) under natural conditions on a micro-plot scale daily. Three techniques that vary in image processing complexity and user interaction were tested to monitor aggregate breakdown. Considering that the soil surface roughness causes shadow cast, the blue/red band ratio is utilized to observe the soil aggregate changes. Dealing with images with high spatial resolution, image texture entropy that reflects soil aggregate breakdown is used. Also, the Huang thresholding technique, which allows estimation of the image area occupied by soil aggregates, is performed. The results show that all three techniques indicate soil aggregate breakdown over time. The shadow ratio shows a gradual change over time, with no details related to weather conditions. Both the entropy and the Huang thresholding technique show variations of soil aggregate breakdown responding to weather conditions. Using data obtained with a regular camera, the results show that freeze-thaw cycles cause soil aggregate breakdown. 



\section{Samenvatting}

Bodem is de buitenste laag van de aarde die de groei van planten ondersteunt en waarvan veel levende wezens afhankelijk zijn. Evenzo is de bodem een natuurlijk lichaam dat bestaat uit vaste stoffen (mineralen en organische stof), vloeistof en gassen die op het landoppervlak voorkomen. Daarom is de bodem een essentiële hulpbron die het leven op aarde ondersteunt. Het biedt de enige geschikte omgeving voor bosgroei en productie van gewassen, waardoor de menselijke voedselvoorziening veiliggesteld wordt. Ook is de grond het medium dat het water filtert en opslaat en is het een reservoir van koolstof. Bodem is de verbinding tussen de atmosfeer, de hydrosfeer, de lithosfeer en de biosfeer. De bodem is echter onderhevig aan degradatie als gevolg van natuurlijke en menselijke factoren. Extreme weersomstandigheden zoals langdurige droogte of extreme regenval zijn vaak bepalend voor de stimulering van dit fenomeen. Bovendien hebben ook de interne fysische en chemische achteruitgang van de bodem, steile hellingen en de afwezigheid van vegetatiedekking invloed op de bodemdegradatie. Evenzo kan menselijk ingrijpen (bijv. Ontbossing, intensieve teelt, overbegrazing, bosbrand, verandering in landgebruik) leiden tot aantasting van de bodem. We worden constant geconfronteerd met het probleem van bodemdegradatie, waarbij de fysische, chemische en biologische toestand van de bodem achteruitgaat. Bovendien verzwakt de bodemdegradatie het vermogen van een ecosysteem om goed te functioneren, beïnvloedt het klimaat door de water- en energiebalansen te veranderen en verstoort het de koolstof-, stikstof- of zwavelcycli. Bodemdegradatie kan dan ook leiden tot meer afvoer en bodemerosie, vervuiling van natuurlijk water en uitstoot van broeikasgassen in de atmosfeer.

Bodemstabiliteit wordt gedefinieerd als het vermogen van de aggregaten om hun banden te behouden onder spanningen die hun desintegratie zouden kunnen veroorzaken. Niet alleen de bodemeigenschappen zoals de verdeling van bodemdeeltjes, mineralogie, gehalte aan organische stof, kationen uitwisselingscapaciteit, maar ook klimaat- en landbeheerpraktijken beïnvloeden de bodemstabiliteit. Hoewel we misschien enig begrip hebben van de factoren die de bodemstabiliteit domineren, ontbreken de ruimtelijke en temporele variaties van deze factoren die de dynamiek van de bodemstabiliteit bepalen. De veranderingen in bodemstabiliteit door ruimte en tijd zijn gecompliceerd vanwege de wisselwerking tussen bodem en klimaatbeheer.

Aangezien de grond niet statisch is, kunnen het vocht, de temperatuur, de hoeveelheid organisch materiaal, de kationen uitwisselingscapaciteit (CEC), oplosbare zouten en $\mathrm{pH}$ fluctueren met de seizoenswisseling. De interacties tussen de bodemmineralen en organische verbindingen creëren mineraalorganische associaties, die fungeren als bind- en cementeermiddelen in de bodem. De anorganische bestanddelen spelen een cruciale rol bij het bepalen 
van de bodemstabiliteit en de organische structuren. Er is echter beperkte kennis van het mineralogisch gedrag van de bodem bij variërende temperaturen en bodemvochtgehaltes die in korte tijd op microschaal optreden. Daarom is het noodzakelijk om het gedrag van bodemeigenschappen vast te leggen waarvoor de proximale beeldspectroscopie een alternatief is, aangezien het in staat is om de spectrale bodembestanddelen te beoordelen die verantwoordelijk zijn voor de bodemstabiliteit. Deze techniek maakt het mogelijk om kwantitatieve bodemgegevens te verkrijgen met de fijne ruimtelijke, spectrale en temporele resoluties. Bovendien is het snel en meet het verschillende bodemeigenschappen met één scan. De benadering van proximale detectie is ook kosteneffectief en milieuvriendelijk in vergelijking met conventionele laboratoriumonderzoeken.

Bodem is een gecompliceerde matrix met een grote ruimtelijke en temporele variabiliteit. De bodemstabiliteit is het resultaat van complexe interacties van de bodemeigenschappen, klimatologische omstandigheden en landbeheerpraktijken. Hoewel deze relaties worden erkend, is het niet helemaal duidelijk welke van de bodemeigenschappen of spanningen verantwoordelijk zijn voor de veranderingen in de bodemstabiliteit in een korte periode. Het is inderdaad niet eenvoudig om de stabiliteit te beoordelen, omdat de bodemeigenschappen die deze regelen in de tijd en in de ruimte veranderen. Het wordt gecompliceerd wanneer rekening wordt gehouden met klimaat- en beheerpraktijken die de bodemstabiliteit op het stroomgebied beïnvloeden. Dit onderzoek beperkt zich echter tot het onderzoek van de organische-minerale interacties in de bodem op micro-plotschaal onder laboratoriumomstandigheden met behulp van beeldvormende spectroscopie. De stabiliteit van de bodem wordt beïnvloed door het vermogen van de aggregaten om hun banden onder spanning te houden. Bodemaggregatie is een proces waarbij aggregaten van verschillende groottes worden samengevoegd en bij elkaar gehouden door verschillende organische en anorganische materialen. Door verschillende spanningen breken de bodemaggregaten echter af tot fijnere deeltjes. Deze micro-aggregaten (20 $250 \mu \mathrm{m}$ ) beïnvloeden het proces van infiltratie, ontwikkeling van korst, afvloeiing van het oppervlak en erosie van de boorrand. Daarom is het essentieel om de dynamiek van de bodemaggregaten onder de natuurlijke omstandigheden op micro-plotschaal te volgen en te kwantificeren.

De Visible Near-I nfrared (VNIR) beeldvormende spectroscopie is in staat de spectrale bodembestanddelen te beoordelen die verantwoordelijk zijn voor de organo-minerale interacties. Deze interactiemechanismen die van nature in de bodem voorkomen, zijn niet alleen afhankelijk van de bodemmineralogie en hun reactief oppervlak, bodemtype en bodemtextuur, maar ook van de verschillende vochtcondities (droog, veldcapaciteit en verzadiging (wateroverlast). Er is echter beperkte kennis van het mineralogisch gedrag van de bodem bij verschillende vochtgehaltes die zich in korte tijd voordoen. Evenzo kunnen cycli van bevriezen en ontdooien tijdens de wintermaanden op de hogere breedtegraden of in de hoge berggebieden de migratie en verandering van de chemische bestanddelen in de bodemmatrix die aan verschillende vochtomstandigheden wordt blootgesteld, aanmoedigen. Dientengevolge kunnen de mineralogische veranderingen in de bodem die optreden als gevolg van het bevriezen-ontdooien proces dat de neerslag, het 
oplossen en het vrijkomen van de bodemmineralen triggert, de bodemaggregatie beïnvloeden. Deze veranderingen konden worden gedetecteerd met behulp van de VNIR-beeldvormingsspectroscopiebenadering. Daarom is het belangrijkste doel van dit onderzoek om het seizoensgebonden effect op de stabiliteit van het bodemoppervlak te onderzoeken met behulp van proximale teledetectie.

Het effect van mineralogieveranderingen van het bodemoppervlak als gevolg van vochtvariaties is het hoofddoel van deze studie. Bodemmonsters zijn verzameld in Nederland, uit (i) Limburg, waar löss de belangrijkste grondsoort is en (ii) in Deventer waar zand overheerst. De Silty Loam-bodems worden echter gebruikt om de mineralogieveranderingen van het bodemoppervlak te onderzoeken. De Silty Loam-bodems ondersteunen een aanzienlijke variabiliteit van het plantenleven omdat in de slibdeeltjes het organische stofgehalte en oplosbare voedingsstoffen voorkomen. Deze bodems zijn echter ook vatbaar voor verschillende omgevingsstress. Daarom worden de Silty Loam-bodemmonsters gebruikt die variëren in gehalte aan organische stof $(0 \%, 4,6 \%$ en $12,3 \%)$ en vochtomstandigheden (droog, veldcapaciteit en verzadiging). Deze grondmonsters worden gedurende acht weken gefotografeerd met behulp van een beeldvormende spectrometercamera onder laboratoriumomstandigheden op een micro-plotschaal na 72 uur.

De Spectral Information Divergence (SID) werd toegepast om het gebied van het bodembeeld dat wordt ingenomen door Mg-clinochlore, goethiet, kwarts dat voor $50 \%$ is bekleed met goethiet, hematiet dimorf met maghemiet te detecteren en te kwantificeren. De SID, een beeldclassificator, is een probabilistische benadering die de divergentiemaat gebruikt om pixelspectra te vergelijken met de referentiespectra. Als deze divergentie, die gerelateerd is aan een drempel, klein is, liggen de pixelspectra dicht bij de referentiespectra. Uit de resultaten bleek dat het percentage van deze mineralen in de loop van de tijd veranderde, afhankelijk van grondsoort en grondbehandeling. Voor de bodems met organisch materiaal waren de mineralogische veranderingen duidelijk bij veldcapaciteit, voor de bodem zonder organisch materiaal waren deze veranderingen merkbaar bij wateroverlast-veldcapaciteitsbehandeling. Met behulp van beeldvormende spectroscopiegegevens toonden de resultaten aan dat de Silty Loam bodemmineralogie in de tijd verandert als gevolg van vochtvariaties.

Evenzo werd het effect van vries-dooi-cycli op de mineralogie van het bodemoppervlak bij verschillende vochtgehaltes bestudeerd. De hypothese is dat het bevriezen-ontdooien proces minerale neerslag, oplossen en vrijkomen van de bodem veroorzaakt. Om deze hypothese te testen, variëren de Silty Loam-bodemmonsters die variëren in het gehalte aan organische stof $10 \%$, $4,6 \%$ en $12,3 \%$ ) en vochtomstandigheden (veldcapaciteit en verzadiging) worden gebruikt. De grondmonsters die worden blootgesteld aan cycli van bevriezen en ontdooien worden gedurende acht weken gefotografeerd met behulp van een beeldvormende spectrometercamera onder laboratoriumomstandigheden op een micro-plotschaal op 72 uur basis.

Met behulp van de SID-benadering werd het bodembeeldgebied bezet door Mg-clinochlore, goethiet, kwarts bedekt met 50\% goethiet, hematiet dimorf 
met maghemiet gedetecteerd en gekwantificeerd (percentage). De resultaten toonden aan dat deze mineralen zich anders gedroegen tijdens vries-dooi-cycli, afhankelijk van het bodemtype en de bodemgesteldheid. Hoewel het gedrag van Mg-clinochlore, goethiet en Qz-Gt afhankelijk was van de aanwezigheid van organisch materiaal, vertoonde de Hm-Mh niet zo'n afhankelijkheid. De resultaten suggereren dat niet alleen de hoeveelheid, maar ook het soort organische stof van vitaal belang is in de bodem die de vries-dooi-cycli doormaakt. Ook wanneer de grond wordt blootgesteld aan de cycli van bevriezen en ontdooien, hebben de vochtomstandigheden (veldcapaciteit of verzadiging) een aanzienlijke invloed op het mineraalgedrag, ongeacht het bodemtype. Het gebruik van afbeeldingsspectroscopiegegevens op de Silty Loam-bodem toonde aan dat de mineralogie van het oppervlak in de loop van de tijd verandert als gevolg van cycli van bevriezen en ontdooien, afhankelijk van het bodemtype en de vochtomstandigheden.

Het is van vitaal belang om de interactie tussen het bodemoppervlak en de omgeving met een hoge temporele resolutie te volgen om deze veranderingen te begrijpen. Aangezien data-acquisitie duur blijft en beeldanalyse vaak gecompliceerd en tijdrovend is, werd ook de mogelijkheid onderzocht om de afbraak van bodemaggregaten eenvoudig en kosteneffectief te volgen. Om dit doel te bereiken, werd een digitale camera in een vaste opstelling gebruikt om dezelfde locatie in de loop van de tijd te fotograferen en tijdreeksen te verzamelen. Vervolgens werd het vermogen van de digitale camera om de afbraak van bodemaggregaten te volgen, geanalyseerd in bodems van verschillende textuurklassen (Silty Loam, Loam en Sandy Loam) onder natuurlijke omstandigheden op een micro-plotschaal. Drie technieken die variëren in complexiteit van beeldverwerking en gebruikersinteractie werden getest op het vermogen om de totale afbraak te volgen. Aangezien de ruwheid van het grondoppervlak schaduw werpt, wordt de blauw / rode bandverhouding gebruikt om de veranderingen in het bodemaggregaat waar te nemen. Omgaan met afbeeldingen met een hoge ruimtelijke resolutie, wordt beeldtextuurentropie gebruikt die het proces van afbraak van bodemaggregaat weerspiegelt. Ook wordt de drempeltechniek Huang uitgevoerd, waarmee het beeldgebied dat wordt ingenomen door grondaggregaten kan worden geschat. De resultaten laten zien dat alle drie de technieken de afbraak van bodemaggregaat in de tijd aangeven. De schaduwverhouding vertoont een geleidelijke verandering in de tijd, zonder details over de weersomstandigheden. Zowel de entropie als de Huang drempeltechniek vertonen variaties in de afbraak van bodemaggregaat als reactie op weersomstandigheden. Met behulp van gegevens die zijn verkregen met een gewone camera, laten de resultaten zien dat vries-dooi-cycli de oorzaak zijn van afbraak van bodemaggregaat. 


\section{Acknowledgements}

I want to express my appreciation to my promoter Prof. Freek van der Meer, for the opportunity to apply for the Erasmus Mundus fellowship. Also, I thank him for supporting me twice to apply for the ITC Foundation fellowship too. Moreover, I thank him for his valuable feedback during the course of this research.

I want to express my gratitude to the Erasmus Mundus A2 SIGMA Ph.D. Programme and ITC Foundation Fellowship Programme for providing financial support to carry on with this Ph.D. research.

I want to thank Prof. Ismail Hoxha from the home institute, who helped me with administrative documents. I say thank you to Dr. Arta Dilo for letting me know about the Erasmus Mundus fellowship program.

I want to express my thanks to my daily supervisor Dr. Dhruba Pikha Shrestha not only for his constructed comments but also for finding the time and helping during a critical time. I thank my daily supervisor and ir. Bart Krol, for their help during the fieldwork campaign. I also thank André de Brouwer for arranging the location at the University of Twente for the outdoor experimental setup, Boudewijn de Smeth for his help with laboratory soil analysis in ITC, the colleagues at the Hogedruklab (University of Twente) for using their facilities to produce the soil sample without organic matter. I also would like to thank Prof. Victor J etten for his help during the first stage of this research. I want to say thank you to all the ITC support staff for their help and willingness to solve any student's problem.

I am glad for having around good friends during my Ph.D. time, Lucas de Oto and Desiree Grandke. Thank you guys not only for the great time we had together but also for always encouraging with my work.

Finally, I thank my family, starting with my parents for teaching me never to give up. They were always supportive and encouraging me to carry on with my work. I also thank my brothers and their wives for their positive attitude towards my work. I am so grateful for having two nephews and a niece. They are always sunlight on my rainy days. I love them very much. 


\section{Table of Contents}

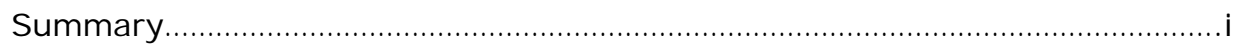

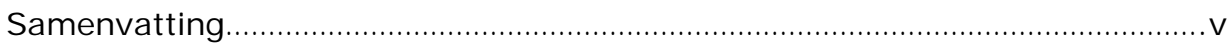

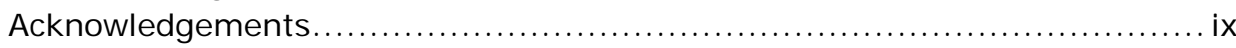

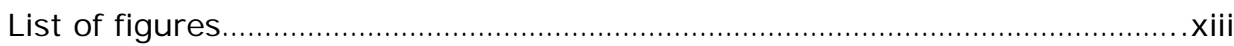

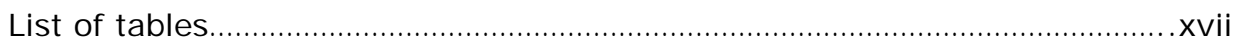

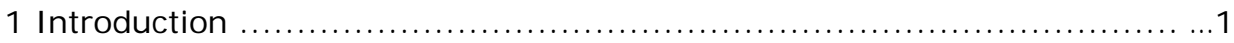

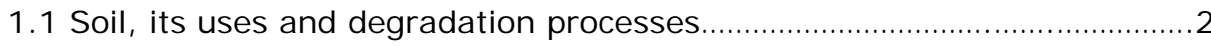

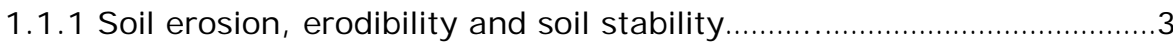

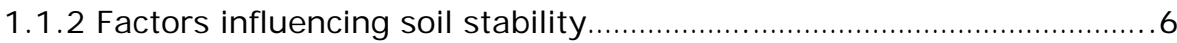

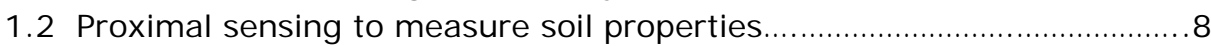

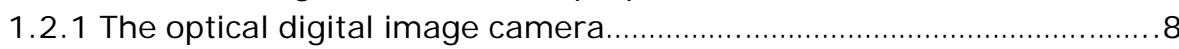

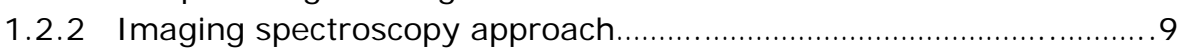

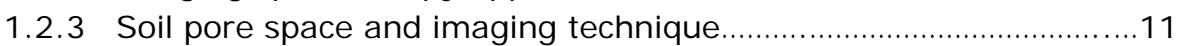

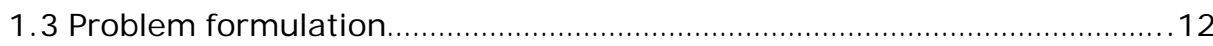

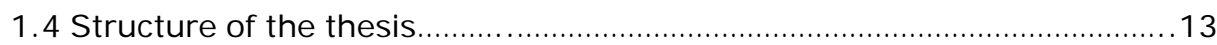

1.5 References.......................................................................... 14

2 Soil sampling, data preparation and lab analysis methods.......................21

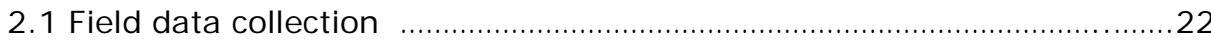

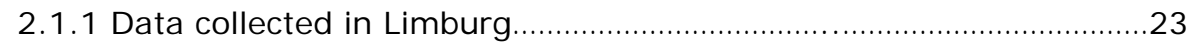

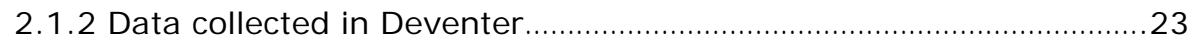

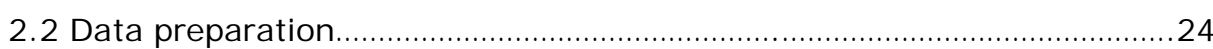

2.3 Soil sample properties derived in the laboratory...............................24

2.3.1 Soil particle size and organic matter determination......................24

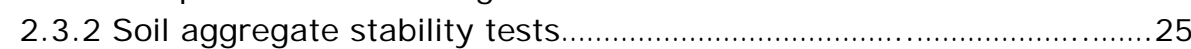

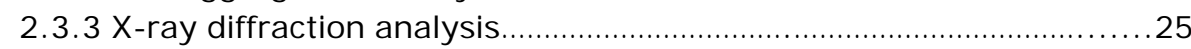

2.3.4 Soil spectra measurement with Analytical Spectral Device.............26

2.3.5Inductivity Coupled Plasma Optical Emission Spectrometry

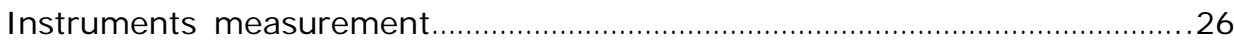

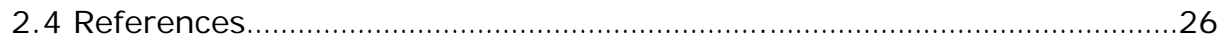

3 Monitoring soil surface mineralogy at different moisture conditions using

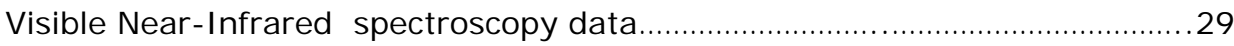

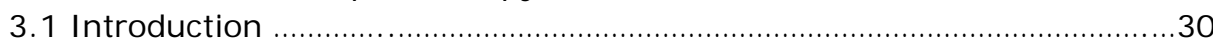

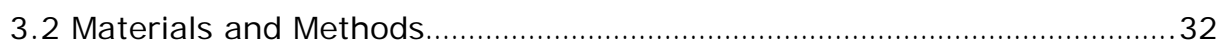

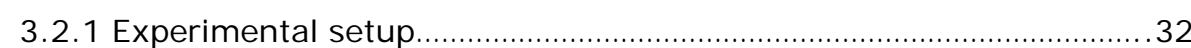

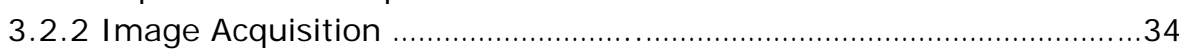

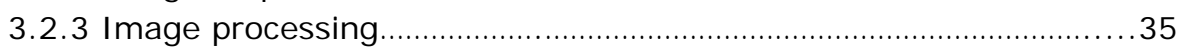

3.2.4 Spectral Information Divergence approach (SID) ........................... 36

3.2.5Inductivity Coupled Plasma Optical Emission Spectrometry

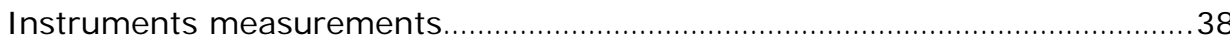

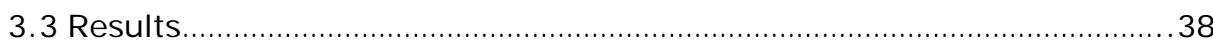

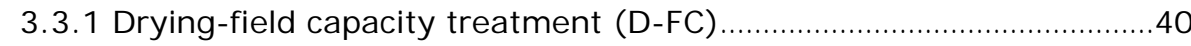




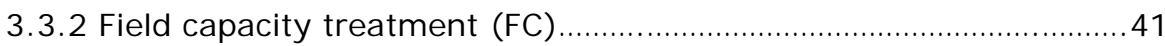

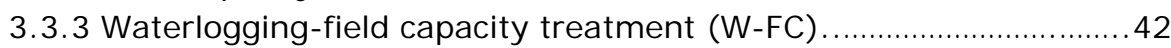

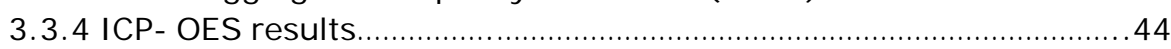

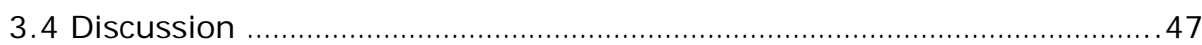

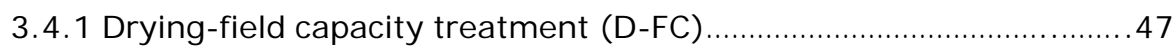

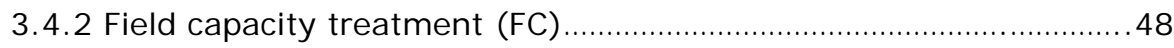

3.4.3 Waterlogging-field capacity treatment (W-FC) ........................49

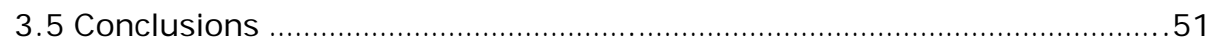

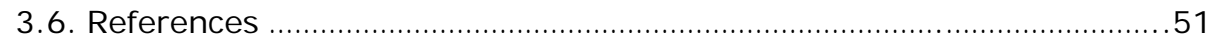

4 Monitoring the effect of freeze-thaw cycles on soil surface mineralogy using

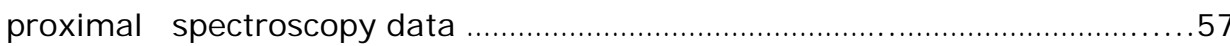

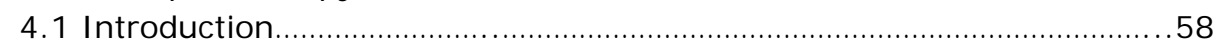

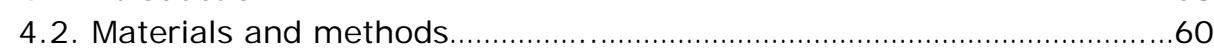

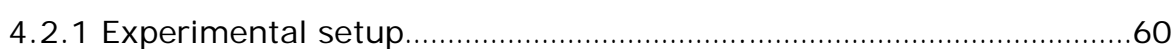

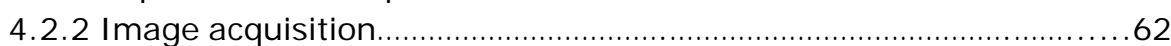

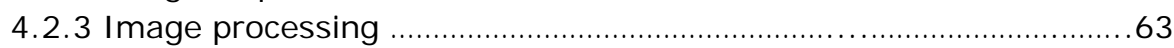

4.2.4 Spectral information divergence approach (SID) .......................64

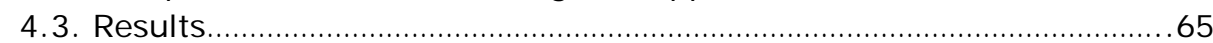

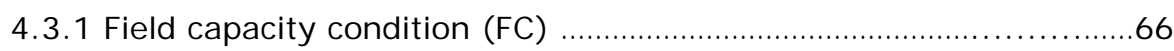

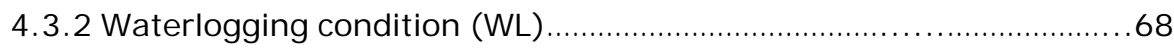

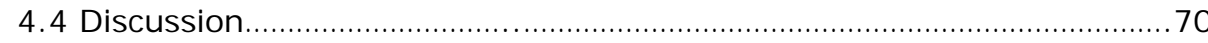

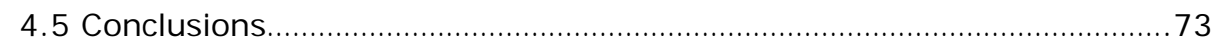

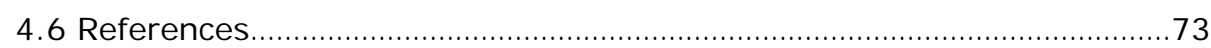

5 Using Color, Texture and Object-Based Image Analysis of Multi-Temporal Camera Data to Monitor Soil Aggregate Breakdown......................................81

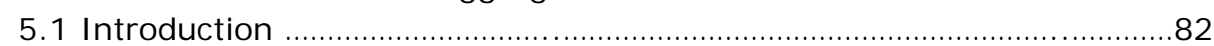

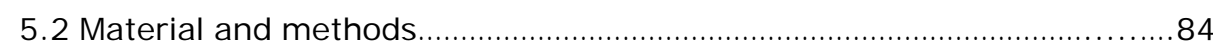

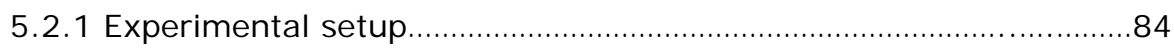

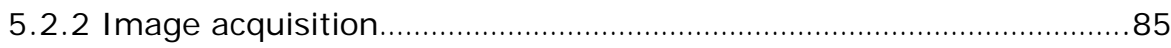

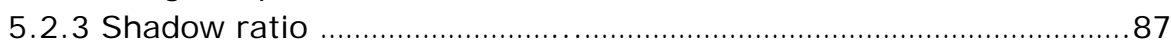

5.2.4 Grey Level Co-Occurrence Matrix: Entropy................................ 88

5.2.5 Object-Based I mage Analysis: Huang Thresholding ...................... 89

5.2.6 Weather Data Collection...................................................... 91

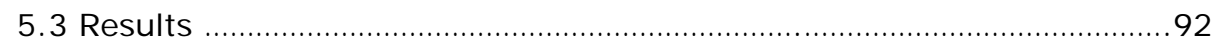

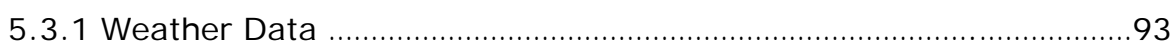

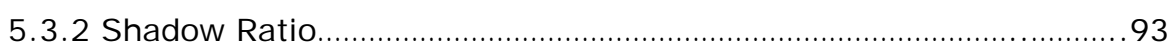

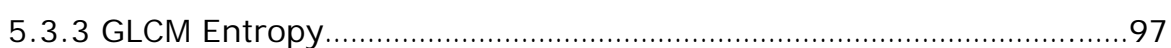

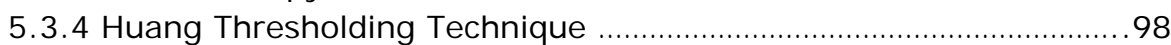

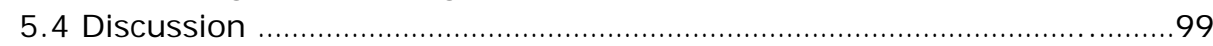

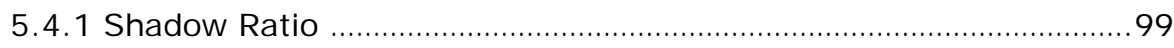

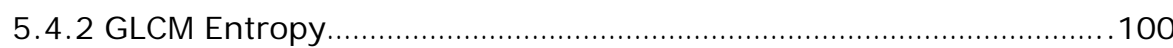

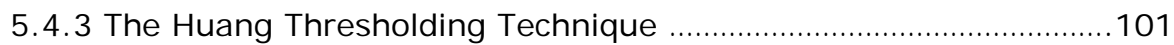

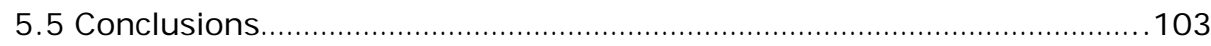

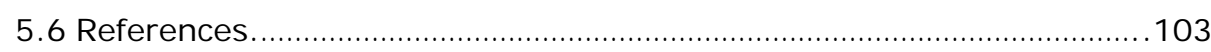




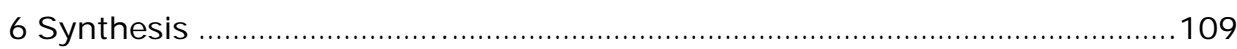

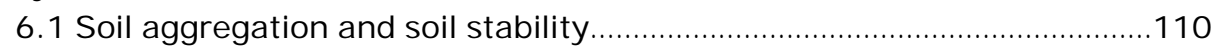

6.1.1 The influence of clay minerals in soil aggregation ...................110

6.1.2 The influence of the freeze-thaw process...............................111

6.1.3 The use of object-based image analysis to monitor aggregate

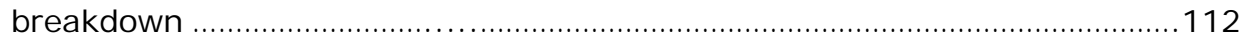

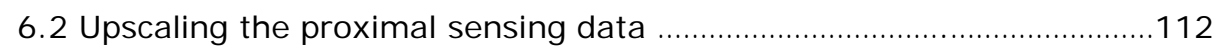

6.3 Influence of land cover and climate change .................................. 114

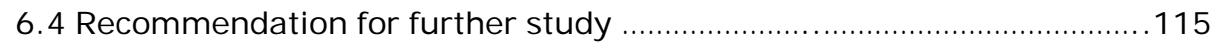

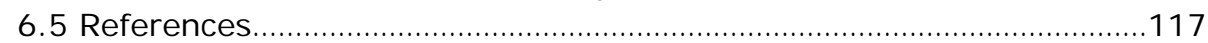

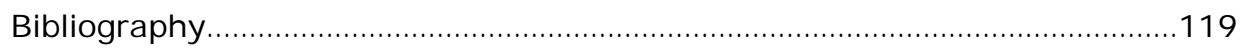

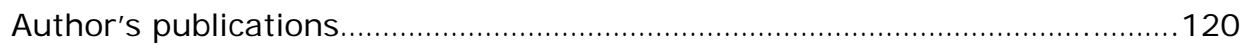




\section{List of figures}

Figure 1-1. Soil properties, together with climate and the land management

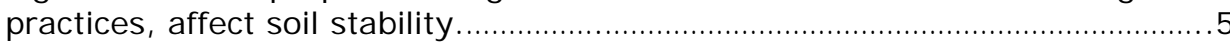
Figure 2-1. The soil samples collected in south Limburg and Overijssel provinces in the Netherlands. Silty Loam and Loam soil samples (Soil 1-Soil 4) were collected in the loess area, and the Sand yLoam sample (Soil 5) was collected in the sandy area in the east. The location of the soil samples is shown with a black dot. (schematic of the Netherlands maps are modified after

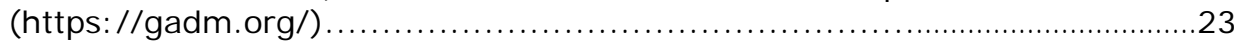
Figure 3-1. The experimental laboratory setup for image data collection. On the tripod in the center is the VNIR imaging spectrometer camera placed at an angle of $90^{\circ}$. Next to the sensor is a sliding table where the soil tray is placed for scanning. On the right and the left side of the sliding table, an external light source is integrated to illuminate the tray during image acquisition...............34 Figure 3-2. Example of an image selected for analysis. In order to avoid shadow, the VNIR image was selected from the upper (a) part of the tray. The image subset of $84 \times 73 \mathrm{~mm}^{2}$ with a pixel size of $2.4 \mathrm{~mm} /$ pixels (b) was

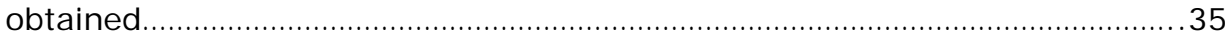
Figure 3-3. Flowchart of the image processing steps followed for each soil image before Spectral Information Divergence image classification was

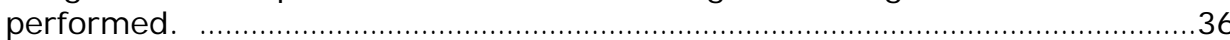
Figure 3-4. The original image (b) of Soil 1 at the beginning of the experiment is in the middle. Using Spectral Information Divergence (SID) classifier with a threshold value of 0.15 , hematite (cherry color) occurrence over the image was defined. The image classification results, on the left (a) and the right side (c), were obtained using ASD and USGS spectral data, respectively. The black arrows indicate the hematite in the original image and its classification results for both ASD and USGS spectral data used. ........................................... 38 Figure 3-5. Example of SID classification results at D-FC treatment at the start (week0), middle (week4) and the end of the experiment (week8) in dry condition (Soil 1- Soil 3). The colors represent the minerals identified in VNIR. All the soils show changes in their mineral distribution over time. The original images at the start of the experiment, together with the scale bar, are also

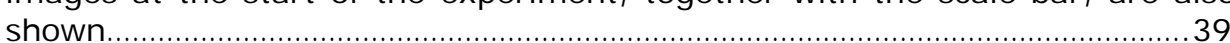
Figure 3-6. The average percentage of Mg-clinochlore (a), goethite $125 \mu \mathrm{m}$ (b), quartz coated $50 \%$ by goethite (c) and hematite dimorphous with maghemite (d) changes for all the soils at the D-FC treatment. The circle, square and plus symbols represent Soil 1, Soil 2, and Soil 3, respectively. The vertical axis characterizes the percentage of each mineral occurring in an image. The scale of the Yaxis varies from $0 \%$ to $100 \%$. In the horizontal axis, wk $1, \ldots$, wk8 stands for week $1, \ldots$, week 8 , when the soil sample was at the dry conditions. Since the soil samples were at the field capacity every three days, wk1fc, ..., wk8fc (week $1 \mathrm{fc}, \ldots$, week $8 \mathrm{fc}$ ) was used to represent it................. 40 Figure 3-7. The average percentage of Mg-clinochlore (a), goethite $125 \mu \mathrm{m}$ (b), quartz coated $50 \%$ by goethite (c) and hematite dimorphous with maghemite $(d)$ changes for all the soils at the FC treatment. The circle, square and plus symbols represent Soil 1 , Soil 2 and Soil 3, respectively. The vertical axis characterizes the percentage of each mineral occurring in an image. The scale of the $Y$-axis varies from $0 \%$ to $100 \%$. In the horizontal axis, wk $1, \ldots$, 
wk8 stands for week $1, \ldots$, week 8 . Since the experiment was performed every three days, wklfc,..., wk8fc (week $1 \mathrm{fc}, \ldots$, week $8 \mathrm{fc}$ ) was also used to represent the results. Here, the soil samples were at the field capacity all the

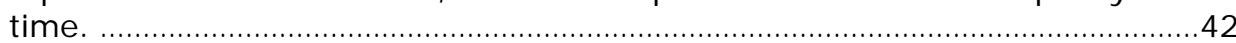
Figure 3-8. The average percentage of Mg-clinochlore (a), goethite $125 \mu \mathrm{m}$ (b), quartz coated $50 \%$ by goethite (c) and hematite dimorphous with maghemite (d) changes for all the soils at the W-FC treatment. The circle, square and plus symbols represent Soil 1, Soil 2, and Soil 3, respectively. The vertical axis characterizes the percentage of each mineral occurring in an image. The scale of the $Y$-axis varies from $0 \%$ to $100 \%$. In the horizontal axis, wklfc, ..., wk8fc stands for week $1 \mathrm{fc}, \ldots$, week $8 \mathrm{fc}$ when the soil samples were at the field capacity conditions. There was no data available at the waterlogging conditions.

Figure 3-9. The percentage of the minerals when the Soil samples were at the field capacity. An exception was the $\mathrm{Hm}$ - Mh at the D-FC treatment, where the Soil samples were at the dry conditions. The vertical axis characterizes the percentage of each mineral occurring in an image. The horizontal axis represents the $\mathrm{Mg}$-clinochlore, goethite $125 \mu \mathrm{m}$, quartz coated $50 \%$ with goethite (Qz-Gt) and hematite dimorphous with maghemite ( $\mathrm{Hm}-\mathrm{Mh}$ ) of Soil 1-Soil 3 (S1-S3) in the drying-field capacity (a), field capacity (b) and waterlogging- field capacity (c) treatments at the start and end of the experiment. The error bars represent the standard deviation of the minerals in triplicated Soil samples. Since the SID approach disregards the self-shadow areas created by various Soil aggregate sizes, these aggregate variations

influenced the standard deviation.

Figure 3-10. The concentration of cations determined using the Inductivity Coupled Plasma-Optical Emission Spectrometry Instruments (ICP-OES) technique at the drying- field capacity (a), field capacity (b), and waterloggingfield capacity (c) treatments for Soil 1-Soil 3. While the results were every week for the D-FC and the W-FC treatments, the results were at three days basis for the FC treatment. 47 Figure 4-1. Schematic design of the experimental laboratory setup for image data collection. On the tripod in the center is the VNIR imaging spectrometer camera placed at an angle of $90^{\circ}$. Next to the sensor is a sliding table where the soil tray is placed for scanning. On the right and the left side of the sliding table, an external light source is integrated to illuminate the tray during image acquisition.

Figure 4-2. Example of an image selected for analysis. In order to avoid shadow, the VNIR image was selected from the upper (a) part of the tray. The image subset of $72 \times 72 \mathrm{~mm}^{2}$ with a pixel size of $2.8 \mathrm{~mm} /$ pixels (b) was obtained. 63

Figure 4-3. Example of the SID classification results at the FC treatment at the start (week0), middle (week4) and the end of the experiment (week8) in the thawing condition (Soil 1- Soil 3). The colors represent the minerals identified in the VNIR. All the soils show changes in their mineral distribution over time. The original images, at the start of the experiment together with the scale bar, are also shown. .66 Figure 4-4. Average Mg-clinochlore, goethite $125 \mu \mathrm{m}$, quartz coated $50 \%$ by goethite and hematite dimorphous with maghemite changes for all the soils at the FC condition. The circle, square and plus symbols represent Soil 1, Soil 2 and Soil 3, respectively. The vertical axis characterizes the percentage of each 
mineral occurring in an image. The scale of the $Y$-axis varies from $0 \%$ to $100 \%$. In the horizontal axis, w1,.., w8 stands for week $1, \ldots$, week 8 , when the soil sample was at the freezing and thawing condition. Each mineral percentage is represented in two separate graphs (freezing and thawing) for easy visualization. However, the soil samples were at freezing for three days and the next three days at the thawing conditions making up one week.............68 Figure 4-5. Average Mg-clinochlore, goethite $125 \mu \mathrm{m}$, quartz coated $50 \%$ by goethite and hematite dimorphous with maghemite changes for all the soils at the WL condition. The circle, square and plus symbols represent Soil 1, Soil 2 and Soil 3, respectively. The vertical axis characterizes the percentage of each mineral occurring in an image. The scale of the $Y$-axis varies from $0 \%$ to $100 \%$. In the horizontal axis, w1,.., w8 stands for week $1, \ldots$, week 8 , when the soil sample was at the freezing and thawing condition. Each mineral percentage is represented in two separate graphs (freezing and thawing) for easy visualization. However, the soil samples were at freezing for three days and the next three days at the thawing conditions making up one week. ...........69 Figure 4-6. The percentage of the minerals when the soil samples were at the freezing treatment. The vertical axis characterizes the percentage of each mineral occurring in an image. The horizontal axis represents the $\mathrm{Mg}$ clinochlore, goethite $125 \mu \mathrm{m}$, quartz coated $50 \%$ with goethite (Qz-Gt) and hematite dimorphous with maghemite (Hm-Mh) of Soil 1 - Soil 3 (S1 - S3) in the field capacity (a) and waterlogging (b) condition at the start and end of the experiment. The error bars represent the standard deviation of the minerals in duplicated soil samples. Since the SID approach disregards the self-shadow areas created by various soil aggregate size, these aggregate variations influenced the standard deviation. ........................................ 70 Figure 5-1. Schematic design of the outdoor experimental setup. On the tripod are both the weather station (on the left) and the camera (in the centre) placed at an angle of $35^{\circ}$. Next to the tripod are the undisturbed soil trays photographed each day. From left to right, the Silty Loam with low OM content, Silty Loam with high OM content, Loam and Sandy Loam is placed. Figure 5-2. Example of an image selected for analysis: the soil trays photographed on 15 November 2014 (a); and one of the five $288 \times 288 \mathrm{~mm}$ image subset with a pixel size $1.8 \mathrm{~mm}$ (b). 86 Figure 5-3. Examples of images that are discarded: snow (a); fog (b); standing water (c); sunlight distribution (d); and frozen surface (e). The last image (f) is an example of an image accepted for further analysis.

Figure 5-4. On the left side are original images $(a, c)$ of Soil 1 . Using the Huang thresholding technique, soil aggregates (black colour) on the right side $(b, d)$ are defined. While images $(a, b)$ show the results at the beginning of the experiment (5 November), images $(c, d)$ show the results at the end of the experiment ( 10 February). The area of some aggregates calculated in $\mathrm{mm}^{2}$ is shown as an example. ...91 Figure 5-5. Original images for all soils at the beginning of the experiment ( 6 November 2014 images), after the first cycle of freeze-thaw followed by the most significant rain event (15 December 2014 images) and at the end of the experiment (10 February 2015 images). All soils experienced aggregate breakdown over time.

Figure 5-6. Weather data (a) together with shadow ratio (b); entropy (c); and area (d) results of Soil 1 are shown. Grey bars and grey line indicate daily 
rainfall and minimum air temperature, respectively. The grey dashed horizontal line indicates the temperature in ${ }^{\circ} \mathrm{C}$. The vertical black dashed lines show missing rainfall data interval from 15 to 23 November 2014. The error bars indicate the standard deviation of shadow ratio (b); and entropy (c). The standard error bars of area (d) represent the 95\% confidence interval of the true population mean for the sample size 49 .

. .94 Figure 5-7. Weather data (a) together with shadow ratio (b); entropy (c); and area (d) results of Soil 2 are shown. Grey bars and grey line indicate daily rainfall and minimum air temperature, respectively. The grey dashed horizontal line indicates the temperature in ${ }^{\circ} \mathrm{C}$. The vertical black dashed lines show missing rainfall data interval from 15 to 23 November 2014. The error bars indicate the standard deviation of shadow ratio (b); and entropy (c). The standard error bars of area (d) represent the 95\% confidence interval of the

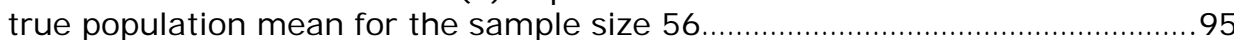
Figure 5-8. Weather data (a) together with shadow ratio (b); entropy (c); and area (d) results of Soil 3 are shown. Grey bars and grey line indicate daily rainfall and minimum air temperature, respectively. The grey dashed horizontal line indicates the temperature in ${ }^{\circ} \mathrm{C}$. The vertical black dashed lines show missing rainfall data interval from 15 to 23 November 2014. The error bars indicate the standard deviation of shadow ratio (b); and entropy (c). The standard error bars of area (d) represent the $95 \%$ confidence interval of the true population mean for the sample size $50 \ldots \ldots \ldots \ldots \ldots \ldots \ldots \ldots \ldots \ldots \ldots \ldots \ldots \ldots . \ldots 5$ Figure 5-9. Weather data (a) together with shadow ratio (b), entropy (c); and area (d) results of Soil 4 are shown. Grey bars and grey line indicate daily rainfall and minimum air temperature, respectively. The grey dashed horizontal line indicates the temperature in ${ }^{\circ} \mathrm{C}$. The vertical black dashed lines show missing rainfall data interval from 15 to 23 November 2014. The error bars indicate the standard deviation of shadow ratio (b); and entropy (c). The standard error bars of area $(d)$ represent the $95 \%$ confidence interval of the

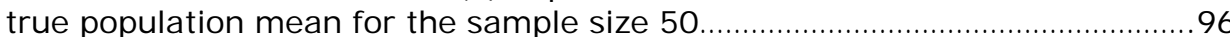
Figure 5-10. Weather data (a) together with shadow ratio (b), entropy (c); and area (d) results of Soil 5 are shown. Grey bars and grey line indicate daily rainfall and minimum air temperature, respectively. The grey dashed horizontal line indicates the temperature in ${ }^{\circ} \mathrm{C}$. The vertical black dashed lines show missing rainfall data interval from 15 to 23 November 2014. The error bars indicate the standard deviation of shadow ratio (b); and entropy (c). The standard error bars of area (d) represent the 95\% confidence interval of the true population mean for the sample size 54

Figure 5-11. Summary results of shadow ratio, entropy and area covered with aggregates obtained for all soils using: band ratio (blue/red) (a); GLCM entropy (b); and Huang thresholding (c) approaches. The grey and white bars indicate the start and the end of the experiment, respectively. Each dataset is relative to each tray and cannot be taken as an absolute value.

Figure $6-1$. Controls of the soil stability at a different spatial scale..............113 


\section{List of tables}

Table 1-1. Position of the absorption features for different soil properties in

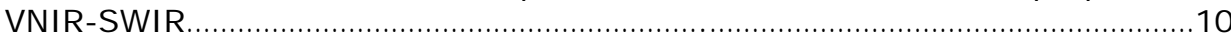

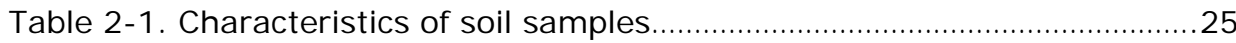

Table 3-1. The soils used in this study. Soils 2-3 (low and high OM) were collected from Limburg province in the Netherlands. Soil 1 (no OM and added hematite) was obtained from Soil 2.

Table 3-2. Specim imaging spectrometer camera characteristics of the Visible

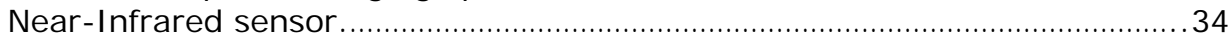
Table 4-1. The soils used in this study. Soils 2-3 (low and high organic matter $(\mathrm{OM}))$ were collected from Limburg province in The Netherlands. Soil 1 (no OM)

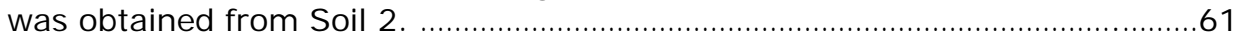
Table 5-1. The soils used in this study. Soils 1-4 (Silty Loam and Loam) were sampled in the Limburg province, the Netherlands, and Soil 5 (Sandy Loam) was sampled in the city of Deventer, the Netherlands. The agricultural crop cultivated on all the fields was maize. However, at the time of soil sampling, this crop was already harvested.. .84 

1 Introduction 


\subsection{Soil, its uses and degradation processes}

Soil is the outmost layer of earth that supports plant growth and many living creatures depending on it. According to the United States Department of Agriculture (USDA, 1999), the soil is a natural body comprised of solids (minerals and organic matter), liquid, and gases that occurs on the land surface, and is characterized by the ability to support rooted plants in a natural environment. Five major factors control soil formation, parent material, climate, organisms, relief and time. In mountainous areas, when the rock falls due to gravity, it can break down physically into smaller fragments. Other processes that contribute to physical weathering are freeze-thaw cycles, exfoliation, abrasion and plant growth. Plant roots may enter the cracks and help in physical weathering. Similarly, water may percolate into the cracks and during freezing the water expands, making the cracks wider and further disintegrate. Likewise, the exfoliation causes the rock to expand because of the changes in the temperature. Also, the expansion of the roots into the rock lead to the rock break down. Abrasion affects the rock surface in various ways by gravity, moving water and strong wind. Likewise, chemical weathering occurs when acidic rainwater or organic matter combined with suitable temperatures react with the rock minerals to form clay minerals and soluble salts. This chemical weathering is known as hydrolysis. Other significant chemical weathering are oxidation, carbonation, cation exchange and chelation. During oxidation, the rock breaks down by oxygen and water. Iron is the most typically oxidized mineral. Moreover, carbonation occurs when the limestone is weathered by rainwater containing dissolved carbon dioxide. In addition, the living organisms break down the rock as well. These weathering processes occur over a long time. However, the disintegrated rock is not soil until the soil comes into a dynamic equilibrium with its environment.

Soil is an essential resource that supports life on earth. It provides a suitable environment for forest growth and crop production, securing human food supplies. Also, the soil is the medium that filters and stores the water and is a reservoir of carbon (Montanarella et al., 2016). Soil is the linkage between the atmosphere, hydrosphere, lithosphere and biosphere providing ecosystem services such as (i) production of food and biomass, (ii) storage, filtering and transformation of compounds, (iii) habitats for living organisms, (iv) carbon pool, (v) source geological and raw materials, (vi) the cultural environment and archaeological heritage (Adhikari and Hartemink, 2016).

Soil degradation is the result of natural and human factors. Indeed, extreme weather conditions such as prolonged droughts or excessive rain intensity are often decisive for this phenomenon's stimulation. Moreover, the internal soil physical and chemical deterioration, steep slopes and vegetation cover absence affect soil degradation. Likewise, human intervention (e.g. deforestation, overcropping, overgrazing, forest fire, land-use change) has led to soil degradation. We are constantly confronted with soil degradation, which involves the decline of the soil's physical, chemical and biological state. There are various soil degradation processes such as the loss of topsoil due to water or wind, the soil fertility depletion due to leaching, salinity due to poor drainage or high salt content of the irrigation water, acidity due to over-application of acidifying fertilizer, pollution due to excessive use of pesticides or manuring, 
compaction due to the use of heavy machinery, sealing and crusting due to insufficient protection to the impact of the raindrop, waterlogging due to the human intervention on the drainage system (Oldeman et al., 1991). Consequently, soil degradation weakens an ecosystem's capacity to function appropriately, affects the climate by changing the water and energy balances, and disrupts the carbon, nitrogen or sulphur cycles (Lal, 2018). As a result, soil degradation may lead to excessive runoff and soil erosion, pollution of natural waters and greenhouse gases emission into the atmosphere.

Intergovernmental Technical Panel on Soil pointed out that $30 \%$ of the soils worldwide were degraded by compaction in 2015 (ITPS, 2015). Indeed, soil erosion and degradation processes are widespread but more severe in developing countries, depending on agricultural practices. According to the FAO report, the annual soil loss from arable lands is 75 billion tonnes globally (GSP, 2017). The soil loss is evident in arid and semi-arid lands, which occupy onethird of the continental surface of the Earth and in the tropics and sub-tropics area. Moreover, Borrelli et al., (2017) estimated the soil loss due to inter-rill and rill erosion of about 17 billion tonnes $\mathrm{yr}^{-1}$ on a global scale. In Europe, a third of productive soil is threatened by increasing population density and consequently by the intensification of agriculture (Oldeman et al., 1991). According to the European Commission, in the EU Member States context, over $10 \mathrm{t} \mathrm{ha}^{-1} \mathrm{yr}^{-1}$ are estimated to be at risk of severe erosion (European Commission, 2018).

\subsubsection{Soil erosion, erodibility and soil stability}

Soil erosion by water is primarily related to particle detachment and transport by rainfall and runoff (Fernández-Raga et al., 2017). Due to climate change, the amount and the frequency of high-intensity rainfall are expected to increase (Eekhout and de Vente, 2019; Ozturk et al., 2015). These rainfall variations, together with the changes in temperature, solar radiation, evapotranspiration rates, the ratio of rain to snow, will substantially impacts soil erosion rates (Praskievicz, 2016). The ability of rainfall to cause erosion is related to rainfall erosivity. When raindrops cause soil detachment, interrill erosion occurs. The soil loss during interrill erosion is related to soil erodibility. Soil erodibility is regarded as the soil susceptibility to particle detachment and transport by erosion agents. Variations in the soil erodibility are controlled by soil particle distribution, organic matter and moisture content, cation-exchange capacity and porosity at the microscale. However, there is limited knowledge of the soil mineralogical behaviour at varying temperatures and moisture contents occurring in a short period at the microscale. These soil properties determine the partition of water between the soil surface and subsurface. As a result, they control water's movement influencing runoff production (Koiter et al., 2017). This study is only focused on soil erodibility and its effects on soil stability.

Vegetation protects the soil against surface erosion in various ways. The interception by the plant breaks the erosive power of the rain. It also decreases the volume of water, reaching the soil surface. Likewise, the surface vegetation and the litter protect the surface from degradation and slow down the overland flow (Bagagiolo et al., 2018). Other factors affecting soil water erosion are the 
slope steepness and its length. The increased slope steepness increases the velocity and surface runoff volume (Bracken et al., 2015). Consequently, the loose soil particles move downslope. When the runoff reaches a flat valley, the flow velocity decreases. Therefore, the particles deposit to the soil surface.

Human activities have accelerated soil erosion through intensive overcropping, overgrazing and deforestation, among others (Rather et al., 2017; Wairiul, 2017). Constant cultivation of the land does not allow the soil to produce humus, which is needed for soil fertility. Overgrazing damage the vegetation on the soil surface. Therefore, the soil becomes exposed and prone to water erosion. Likewise, deforestation accelerates soil erosion (Bladon et al., 2019). Also, without the roots of the trees, the soil loses its structure.

In an agricultural area, soil erosion is affected by cultivation practices. Soil is less exposed to water erosion during the cropping season due to the crop canopy. However, fields may also be bare depending on the crop growing cycles. During the crop-free period, tillage is used for various of reasons such as seedbed preparation, incorporation of fertilizers and crop residues. Tillage increases infiltration when it loosens the surface crust or disrupts dense soil layers. Nevertheless, tillage practices can also make the soil vulnerable to water erosion (Adimassu et al., 2019; Cerdà and Rodrigo-Comino, 2020).

Soil erosion by water has significant on-side as well as off-side effects. The main on-side effects of water erosion are the loss of soil structure (compaction and crusting) and the soil loss fertility by removing the fertile part of the topsoil reducing productivity. Likewise, the soil washed away by runoff creates offside effects such as the mudflow, blockage of the drainage channel, causing floods. The soil sediments can reduce the capacity of reservoirs affecting irrigated agriculture and hydro-electricity generation.

Soil erosion models have been developed to estimate soil loss. The most distinguished division between the soil erosion models is empirical and physically based. The empirical model's output is only a lumped annual soil loss estimation (Alewell et al., 2019). On the contrary, the physically-based models consider both the spatial and temporal variability of the erosion processes (Cai et al., 2019; Fernández and Vega, 2018). One of the crucial inputs to erosion models is the soil properties (soil particle distribution, porosity, water retention capacity and surface roughness) and their spatial and temporal variations. Remote Sensing (RS) can play a significant role in acquiring relevant data such as Digital Elevation Models (DEM) or land use in order to improve their performance (Borrelli et al., 2018; Shrestha et al., 2014; Teng et al., 2016).

Soil stability is defined as the aggregates' ability to maintain their bonds under stresses that might trigger their disintegration (Cerda, 2000). There is still limited knowledge of the soil mineralogical behaviour at varying temperatures and moisture contents occurring in a short period at the microscale. The soil properties such as soil particle distribution, mineralogy, organic matter content, cation-exchange capacity, and climate and land management practices affect soil stability as it is shown in Figure 1-1. 


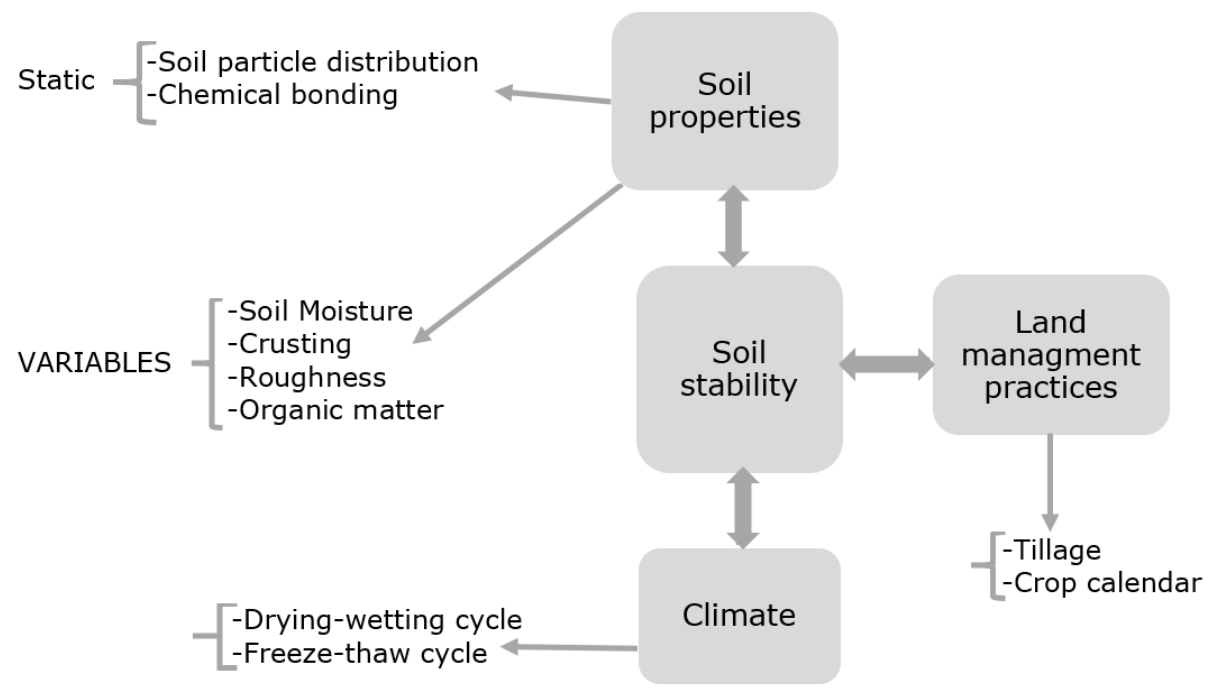

Figure 1-1. Soil properties, together with climate and the land management practices, affect soil stability.

The chemical bonding between particles might be occurred by iron oxide cement, silica, alumina, carbonates and organic compounds and water content. Soil organic matter, which is responsible for many soil properties such as fertility, water retention and soil structure stability, is a crucial factor causing cohesion. Likewise, clay content in the soil particle distribution influences soil stability (Buchmann and Schaumann, 2018; Xue et al., 2019). The amount and degree of dispersion and the clay mineralogy and its orientation should be considered.

Soil stability is at equilibrium when the soil moisture is at the water holding capacity, and the external factors (climate and management practices) are insignificant. However, repeated drying and wetting cycles can cause changes in soil chemical composition due to the migration of soil chemical elements (Bravo-Garza et al., 2009; Pires et al., 2011), affecting the soil stability. In general, the more moisture, the more intense the weathering and leaching processes such as the transport of soluble salts, Fe and Al oxides, clay minerals and carbonates. Denef et al., (2002) suggested that drying could contribute to the interaction between organic molecules and mineral surfaces, increasing cohesion upon drying after studying the effects of wetting and drying on aggregate formation in soils dominated by 2:1 clay minerals.

Soil surface crusting occurs due to changes in aggregate stability. Rainfall, as a driving force, could destroy the soil aggregates via two processes: (i) the direct impact of the raindrops may mechanically disintegrate the aggregates leading to the rearrangement of the soil aggregates (ii) physical-chemical dispersion of the clays, which then move into the soil with infiltrating water (Agassi et al., 1981). When the aggregates are reorganised with limited particle displacement, the structural crust is formed. After the rainstorm, the sedimentary crusts results mainly from the clay particle displacement (Cerdan et al., 2002). Both mechanisms help create a thin crust layer with a light colour, 
high bulk density and low porosity. Soil surface crusting reduces the soil's infiltration capacity and consequently enhances the surface runoff (Kuhn, 2007). Crusting also alters the soil characteristics such as the shear strength and soil roughness, influencing the sediment detachment and transport processes.

While we may understand of the factors dominating soil stability, the spatial and temporal variations of these factors controlling the soil stability dynamics are still missing. Indeed, the soil stability changes through space and time are complicated because of the soil-climate-management practices interactions.

\subsubsection{Factors influencing soil stability}

\section{Physical factors}

Aggregate stability is one of the most important indicators to determine the soil's physical behaviour (Deviren Saygın et al., 2012). Soil aggregation is the process by which aggregates of different sizes are joined and held together by the bonding of clay particle, polyvalent metal ( $\mathrm{Fe}, \mathrm{Al}, \mathrm{Ca}$ ) and organic matter (Churchman, 2018; Totsche et al., 2018). However, there is limited knowledge of the soil mineralogical behaviour at varying temperatures and moisture contents occurring in a short period at the microscale.

Due to the environmental stresses, the soil aggregates break down into finer particles. These micro-aggregates (20- $250 \mu \mathrm{m}$ diameter) affect infiltration, crust development, runoff and interrill erosion. Aggregates can be classified into different sizes ranging from micrometre to centimetre scale (Almajmaie et al., 2017; Asano and Wagai, 2014). The mechanisms that break down the soil aggregates are (i) slaking, i.e. breakdown caused by the compression of entrapped air during wetting, (ii) breakdown by differential swelling, (iii) breakdown by raindrop impact, (iv) physic-chemical dispersion due to osmotic stress (Le Bissonnais, 1996). Of course, all these processes contribute to the loss of soil structure.

Aggregate stability indices such as the mean weight diameter (MWD), geometric mean diameter (GMD), percentage of aggregates with a diameter > $2 \mathrm{~mm}(\mathrm{AGRI})$ and the stable aggregates index (SAI) are used to evaluate the state of soil aggregation (Wendling et al., 2005). Since these indices do not represent the changes of organo-mineral interactions at the micro-aggregate scale, the specific surface area (SSA) is used to describe these interactions (Kaiser and Guggenberger, 2003; Kögel-Knabner et al., 2008). Moreover, Rabot et al., (2018) pointed out that the soil processes depend on pores' morphological structure and solid, which cannot be addressed based on the mechanical stability of aggregates.

The methods used to measure the soil aggregate stability differ on the sample pretreatment aiming to homogenise the water content, the amount of energy applied for the dispersion, the type of sieving and its duration and different scales at which the stability can be determined (Almajmaie et al., 2017; Peng et al., 2015). Therefore, no standard method exists for the determination of soil aggregate stability. However, based on Le Bissonnais, (1996), an international standard (ISO 10930, 2012) is developed to access soil aggregate stability subject to water. 
An alternative solution to estimate the soil aggregate stability is by using predictive models. Indeed, the pedotransfer functions (PTFs) have been used to predict the soil properties such as hydraulic conductivity of soil, fertility status, iron content and cation exchange capacity (Annabi et al., 2017; Stoppe and Horn, 2018). Using linear regression and advanced machine learning techniques, the PTFs are applied to estimate the soil aggregate stability (Rivera and Bonilla, 2020). Since the PTFs require the use of at least one of the techniques such as diffuse infrared spectroscopy, X-ray fluorescence, inductively coupled plasma optical emissions spectroscopy, laser granulometry or soil mechanical resistance (Annabi et al., 2017; Erktan et al., 2016), there is no a universal model for predicting aggregate stability for a wide range of soil types and local conditions.

\section{Chemical components}

Soil aggregate stability is affected by internal factors such as organic matter, $\mathrm{Fe}$ and $\mathrm{Al}$ oxides, clay mineralogy, contents of $\mathrm{CaCO}_{3}$ and gypsum, the ionic strength and ion concentration (Stoppe and Horn, 2018). Of course, the external factors play an essential role in the soil aggregate stability too. It is demonstrated that soil organic matter is stabilized due to organo-mineral interactions (Angst et al., 2017). While the soil organic matter is the binding agent of the soil macro-aggregates, the mineralogy, cations and cementing agents (amorphous iron oxides) are related to the micro-aggregate stability (Bottinelli et al., 2017). Oxides promote aggregation and improve aggregate stability through (i) organic materials absorb on oxide surfaces and coprecipitation, (ii) electrostatic binding between the positively charged oxides and negatively charged clay minerals, (iii) coating of oxides on the surface of minerals forming bridges between primary and secondary particles (Chen and Sparks, 2015). Depending on the environmental conditions, especially the $\mathrm{pH}$, the oxide minerals carry different charges. Soil oxides have a high point of zero charges enabling the sorption of negatively charged organic matter and reaction with clay minerals under field conditions (Kaiser and Guggenberger, 2007).

Likewise, the clay particles act as binding agents forming organo-mineral interactions influencing the soil aggregation process (Buchmann and Schaumann, 2018; Regelink et al., 2015). One of the mechanisms contributing to soil structural stability is the cation bridging between the negatively charged clay surface and organic components via the polyvalent cations (Buchmann and Schaumann, 2017). Moreover, positively charged organic materials interact directly with the negatively charged clay surfaces.

The mechanisms controlling microaggregates' formation and stability are complicated because of different minerals and organic materials interactions (Totsche et al., 2018). Microaggregates' stability depends on environmental conditions, such as moisture, $\mathrm{pH}$, redox-potential and ionic strength. Therefore, chemical interactions like the electrostatic attraction or van der Waals forces are crucial for forming microaggregates (Lehtinen et al., 2014). Since these bindings depend on the mineral types and their surface area, the oxides contribute significantly to this process (Sollins et al., 2009). Likewise, the coating of clay particles around organic matter leads to the formation of stable micro-aggregates (Torres-Sallan et al., 2017). Regelink et al., (2015) found that Fe-hydroxides have a more robust ability to sorb the organic matter 
than the clay. However, studies on the micro-aggregate stability and the controlling factors such as varying temperatures and moisture contents occurring in a short period are still not fully understood.

\subsection{Proximal sensing to measure soil properties}

Environmental concerns must be identified, estimated and monitored efficiently. It is well known that ground-based methods are time-consuming and expensive. Likewise, achieving standardization is challenging, due to the different techniques used. Moreover, updating the environmental conditions with conventional methods over large areas is difficult. Remote Sensing (RS) is a fast, nondestructive, reproducible, cost-effective, and environmentalfriendly approach. Within a different spatial, temporal and spectral resolution, the RS provides continuous data. These data are suitable for the assessment and monitoring of environmental conditions, including soils.

Many studies have shown that soil retrieving information work well when using proximal sensing, but their accuracy drops when RS techniques are being used (Mulder et al., 2011). Proximal sensing measurements are discrete in space. While proximal sensing can be used as a primary data source, RS is used as secondary data to predict the soil properties. In this way, the high spectral resolution of the proximal sensed data can be combined with the RS data's spatial coverage. This study focuses on soil erodibility and monitoring soil stability's governing processes by proximal remote sensing techniques.

\subsubsection{The optical digital image camera}

The development of Charge-Coupled Device (CCD) and Complementary Metal Oxide Semiconductor (CMOS) digital cameras with high spatial resolution have made it possible to relate the colour to soil properties such as soil texture Aitkenhead et al., (2018), organic carbon Wu et al., (2017), iron oxide content Levin et al., (2005).

Digital cameras provide images on the visible portion of the spectrum. The red, green and blue (RGB) bands can be converted to colour indices or other colour space to determine various soil properties. Therefore, Gholizadeh et al., (2020) photographed the soil samples vertically using a 12-megapixel Nikon D3300 digital camera at a distance of $46 \mathrm{~cm}$. They aimed to measure the soil organic carbon (SOC) with tristimulus colour values and indices derived from the digital camera's images. This study emphasized that the CIELab colour space was a better predictor of the SOC than RGB bands.

Xu et al., (2019) acquired soil images with a Nikon D90 camera placed at a 1 $\mathrm{m}$ distance from the target to estimate the soil salinity content (SSC) and soil surface roughness (SSR). Next, using the red, green, blue and grey colour, the percentage of digital number (DN) occurring in each of these colour components were calculated. Since the SSC and SSR influence the DN value, their percentage (SSC and SSR) for each colour component can be estimated. Moreover, correlating the DN with SSC and SSR percentages using the partial least squares regression, a coefficient of determination 0.90 and 0.71 and a ratio of performance to the deviation of 3.11 and 1.87 were derived, 
respectively. This study showed that the digital image camera could estimate the soil salinity and surface roughness.

Viscarra Rossel et al., (2008) used a Kodak DC290 digital camera mounted on a tripod at $0.5 \mathrm{~m}$ to the Petri dish to acquire the soil images in the visible range (RGB bands). In this study, the transformation of the RGB colour space to other ones and a redness index were used to develop pedotransfer functions to predict the soil organic carbon and iron. They concluded that using a digital camera and an appropriate colour space model, accurate predictions of the soil iron and organic carbon can be obtained.

Digital image cameras are easy to operate, and the data obtain are used without complex processing. Therefore, they can be used to provide a fast and low-cost estimation of the soil properties. However, the digital cameras are limited to the visible portion of the spectrum, not allowing the soil properties's determination outside this region. Moreover, due to a coarse spectral resolution, the overlapping of different soil attributes might occur. Furthermore, the spatial image acquisition with these digital cameras should be increased.

\subsubsection{Imaging spectroscopy approach}

Generally, the soil reflectance across the entire spectrum decreases when the soil moisture increases. The same phenomenon is observed with organic matter content. As organic matter content increases, the soil spectral response decreases over the entire spectrum. Variations in the soil reflectance occur when there is a change in the light distribution. Soil roughness also affects the soil's optical properties because the light is held in the rough surfaces of coarse soil aggregates. Moreover, the soil aggregate size and shape also influence the reflectance properties. If the soil aggregate size expands in diameter, then a decrease in reflection will occur due to shadow effect.

On the other hand, a smooth surface (spherical soil aggregates) will yield higher reflectance values. Furthermore, the decreased pore size causes lower moisture content resulting in a higher albedo. Additionally, the effect of clay is different depending on its mineralogy and interaction with other minerals. Indeed, these variations affect the soil spectral response.

Soil properties such as texture, organic matter, iron content, moisture content and mineralogical composition can be determined spectrally under laboratory or field condition with imaging spectroscopy. Table 1-1 summarizes the absorption positions for different soil properties in the visible, near-infrared and short-wave infrared (VNIR-SWIR) portion of the electromagnetic spectrum (Stenberg, 2010). 
Introduction

Table 1-1. Position of the absorption features for different soil properties in VNIR-SWIR (Stenberg, 2010).

\begin{tabular}{|c|c|}
\hline Wavelength $(\mathrm{nm})$ & Material \\
\hline $\begin{array}{l}1660,1728,1754,2056,2264, \\
2306,2347 \\
930,420,480,660,1700 \\
620,880,510 \\
2200 \\
2290 \\
2230 \\
2268 \\
1395,1415,2778,2165,2207 \\
1400,1900,2200 \\
1400,1900,2200,2340,2445 \\
2335,2160,1990,1870,2500 \\
970,1200,1400,1780\end{array}$ & $\begin{array}{l}\text { Organic matter } \\
\text { Fe (goethite } \mathrm{FeOOH}) \\
\text { Hematite (Fe2O3) } \\
\text { Al-OH(kaolinite, montmorillonite, and } \\
\text { Illite) } \\
\text { Fe-OH } \\
\text { Mg-OH(illites and montmorillonites) } \\
\text { Gibbsite (AlOH) } 3 \\
\text { Kaolin } \\
\text { Smectite } \\
\text { Illite } \\
\text { Carbonates } \\
\text { Water }\end{array}$ \\
\hline
\end{tabular}

Imaging spectroscopy provides detailed information on the soil surface properties thanks to high spectral resolution. Indeed, to obtain quantitative soil information, high spectral resolution data are required (Viscarra-Rossel et al., 2006).

Reflectance changes are related to physical characteristics (e.g. particle size or high soil moisture content), whereas the absorption features depend on the examined matter's chemical composition (e.g. OH in clay lattice). Therefore, it can be used as an indicator of changes occurring during soil crust formation. Based on this assumption de Jong, (1992) showed that the albedo of crusted soil changes. It was indicated that crusted surfaces had a higher reflectance than non-crusted ones using a portable field spectrometer (Ben-Dor et al., 2003). The high albedo is caused by a decrease in pore size, a fine texture, a smooth surface with fewer shadow effects in the crusted surface (Eshel et al., 2004). Due to the aggregate destruction and crusting process, an increased absorption feature around $2200 \mathrm{~nm}$ (clay particle) was observed (Goldshleger et al., 2004).

Since soil is a complex matrix, one component's spectral features can be hidden or slightly shifted by another component (Ben-Dor et al., 2002). Laboratory soil spectroscopy, together with the regression prediction models, has been widely used to assess soil properties. Some of the soil properties predicted from the reflectance data are organic carbon, iron oxides, clay minerals and carbonates (Viscarra Rossel et al., 2016).

Several studies have revealed the efficacy of imaging spectroscopy to predict soil organic carbon (SOC) (Forkuor et al., 2017). SOC has diagnostic absorption features in VNIR and SWIR used to estimate its concentration in the soil. Recently, Guo et al., (2019) showed that using spectral information (400-2350 $\mathrm{nm}$ ) and partial least square regression model (PLSR), the SOC stock could be predicted efficiently.

The absorption features in the visible and near-infrared $(400-1000 \mathrm{~nm})$ region of the spectrum are representative of the iron oxides, such as hematite and 
goethite. The detection of these oxides in the VIS-NIR is possible even when they occur in small amounts in soil (Rossel et al., 2009).

In the SWIR region of the spectrum, the spectral features of the carbonates occur. To predict the carbonates, Khayamim et al., (2015) used two approaches: PLSR and continuum removal (CR). They demonstrated that the carbonates were better predicted with the PLSR model than the CR one. However, Gomez et al., (2008) pointed out that the prediction of calcium carbonate with the PLSR was a little more accurate than the CR. These results could be related to the type of carbonate mineral occurring in the soil having different band positions.

\subsubsection{Soil pore space and imaging technique}

Soil compaction is caused by natural and human activity. Due to raindrop impact, natural compaction occurs as a soil crust. However, the primary factor of soil compaction is the use of heavy machinery in the agricultural field. Compaction reduces the soil capacity to hold water because of increased soil bulk density and reduced porosity. As a result, the soil infiltration and drainage capacity decrease, resulting in runoff and erosion rates increase. Therefore, compaction may cause not only the loss of fertile topsoil in the hill slopes, but it may also cause flooding in the lowlands due to increased runoff. Although the conventional soil survey methods provide information on the soil structure volumetric deformation, there is no information about the porous system's morphology and geometric properties (Poehlitz et al., 2019; Rabot et al., 2018).

The aggregate stability indices provide limited information for the inner architecture of the soil aggregates. Therefore, the formation and stabilization of micro-aggregates require an understanding of the primary soil particles's pore arrangement.

X-ray computed tomography (X-ray CT), a non-destructive imaging technique, is used to evaluate the soil pore space (Schlüter and Vogel, 2016). Computed tomography enables 3D quantitative image analysis of the internal soil structure, detecting pore geometries' spatial distribution (Jarvis et al., 2017). Moreover, micro CT provides detailed images depending on the spatial resolution, the soil porosity, pore-volume, pore connectivity, pore tortuosity, number of soil pores, pore sphericity and pore micromorphology can be estimated (Borges et al., 2018).

One limitation of the X-ray CT is the trade-off between image resolution and sample size (Rabot et al., 2018). While the information on mesopores $(<10$ $\mu \mathrm{m}$ or $<50 \mu \mathrm{m}$ ) requires a small soil core (Schlüter and Vogel, 2016), large macropores samples (20 cm and image resolution of $100 \mu \mathrm{m}$ ) are necessary to represent the preferential flow (Paradelo et al., 2016). Another disadvantage of X-ray tomography is the effort to collect undisturbed samples at various soil depths. Also, analyzing large image datasets is time-consuming. Moreover, the segmentation step is sensitive to subjective errors (Schlüter et al., 2014). 


\subsection{Problem formulation}

Soil is a complex mixture of organic and inorganic constituents. Since the soil is not static, its moisture, temperature, amount of organic matter, cation exchange capacity (CEC), soluble salts and $\mathrm{pH}$ may fluctuate with the seasons. The interactions between the soil minerals and organic compounds create mineral-organic associations, acting as binding and cementing agents in the soil. The inorganic constituents play a critical role in determining soil stability than the organic ones (Barto et al., 2010). However, there is limited knowledge of the soil mineralogical behaviour at varying temperatures and moisture contents occurring in a short period at the microscale. Therefore, it is necessary to capture the behaviour of soil properties for which the proximal imaging spectroscopy could be an alternative since it can assess the spectral soil constituents responsible for soil stability.

Soil is a complicated matrix with high spatial and temporal variability. Soil stability is a result of complex interactions of the soil properties, climate and land management. Although these relations are recognised, it is not fully understood which soil properties or stresses are responsible for the soil stability alterations over a short period. Indeed, it is not easy to assess stability because the soil properties that control it change over space and time. It becomes complicated when the climate and management practices that affect the soil stability at the catchment scale are considered. The soil stability is affected by the capability of the aggregates to maintain their bonds under stress. Soil aggregation is a process by which aggregates of different sizes are joined and held together by different organic and inorganic materials. However, as a result of different stresses, the soil aggregates break down into finer particles. These micro-aggregates $(20-250 \mu \mathrm{m})$ affect the process of infiltration, crust development, runoff and interrill erosion. Therefore, it is essential to monitor and quantify the soil aggregates dynamics under natural condition.

The VNIR imaging spectroscopy can assess the spectral soil constituents responsible for the organo-mineral interactions. These interaction mechanisms occurring naturally in the soil depend not only on the soil mineralogy and their reactive surface area, soil type and soil texture but also on the moisture condition (drying, field capacity and waterlogging). However, there is limited knowledge of the soil mineralogical behaviour at different moisture content occurring in a short period. Moreover, freeze-thaw cycles might encourage migration and alteration of the chemical constituents in the soil matrix exposed to different moisture conditions. Therefore, the soil mineralogical changes occurring due to the freeze-thaw process triggering the soil mineral precipitation, dissolution and release might affect the soil stability.

\section{Research objectives and questions}

The research's main objective is to investigate the seasonal effect on the soil surface stability using proximal remote sensing. This leads to the following subobjectives and the related research questions:

Study of the effect of soil surface mineralogy alterations due to moisture variations. 
- Does the soil surface mineralogy change over time due to changes in soil moisture conditions?

- How do the minerals behave in the soil matrix with various organic matter contents at different moisture contents?

Study of the effect of freeze-thaw cycles on the soil surface mineralogy at different moisture content.

- What is the impact of the freeze-thaw process on soil mineralogy?

- How much does the percentage of the soil surface mineralogy change over time due to the freeze-thaw cycles?

Exploring the possibility to monitor the soil aggregates breakdown.

- Can the monitoring of soil aggregate breakdown identify periods of low soil stability?

- Which image analysis technique, e.g. pixel-based or object-based, is better in indicating the soil aggregate breakdown?

\subsection{Structure of the thesis}

This thesis consists of six chapters. Chapter one and chapter six are the introduction and synthesis, respectively. Chapter two presents the data used in this research. The remaining chapters address specific components fulfilling the research objectives, the methods used for that, and discussions of results obtained. Below the overall content per chapter is presented:

Chapter 1 gives an overview of the soil's importance as a natural resource, and it points out the problem of soil loss due to various stresses. Moreover, this chapter focuses on the physical and chemical factors affecting soil stability and how it is estimated. Furthermore, an outline of the proximal remote sensing approach dealing with various soil properties is also presented.

Chapter $\mathbf{2}$ describes of the field data collection, data preparation, and analysis in the laboratory.

Chapter 3 investigates the soil surface mineralogical alterations due to the moisture variations using the VNIR imaging spectroscopy approach under laboratory conditions. The silty loam soils varying in the organic matter content placed at the drying-field capacity, field capacity and waterlogging-field capacity treatments were scanned on a $72 \mathrm{~h}$ basis with an imaging spectroscopy camera for eight weeks. This experiment showed these minerals behaved differently, depending on the soil type and soil treatment. Using imaging spectroscopy data on the silty loam soil, we showed that the surface mineralogy changes over time due to varying moisture conditions.

Chapter 4 examines the effect of freeze-thaw cycles on the soil surface mineralogy at different moisture content using the VNIR imaging spectroscopy technique under laboratory conditions. Three silty loam soils varying in the organic matter content (no, low, and high) placed at field capacity and waterlogging treatments were exposed to freeze-thaw cycles. The soil samples were scanned with the imaging spectroscopy camera on a $72 \mathrm{~h}$ basis for eight 
weeks. This experiment showed that the surface mineralogy changes over time due to freeze-thaw cycles, depending on the soil type and the moisture conditions.

Chapter 5 deals with monitoring the soil aggregates breakdown under natural conditions using a regular RGB camera. Five different soil varying in texture classes (silty loam, sandy loam and loam) and organic matter content (agricultural soil and forest soil) were exposed to outside weather circumstances during the winter season, with exposure to rainfall and freezingthawing. I mages and weather data were collected daily for three months. Due to the kinetic energy of rainfall and freezing-thawing, the aggregates break down, and the surface smooths out. Using different indices derived from the images data, a decrease in aggregate size and loss of aggregates was visible in the image series.

Chapter $\mathbf{6}$ is focused on synthesis. The main findings of this thesis are highlighted. Moreover, upscaling the proximal sensing results to field condition or catchment scale are discussed. Furthermore, since this work is based on soil surface observations, the influence of land cover and climate change is considered. Finally, the recommendations for future research are given.

The core chapters of this thesis are based on peer-reviewed journal and proceeding papers. Since the experiments are performed on the same soil samples, there are some repetitions regarding soil samples' characteristics. Moreover, each of the scientific chapters is standalone, and there is no need to consult the other chapters for understanding. 


\subsection{References}

Adhikari, K., Hartemink, A.E., 2016. Linking soils to ecosystem services - A global review. Geoderma. 262, 101-111.

Adimassu, Z., Alemu, G.,Tamene, L., 2019. Effects of tillage and crop residue management on runoff, soil loss and crop yield in the Humid Highlands of Ethiopia. Agricultural Systems. 168, 11-18.

Agassi, M., Shainberg, I., Morin, J., 1981. Effect of Electrolyte Concentration and Soil Sodicity on Infiltration Rate and Crust Formation1. Soil Science Society of America Journal. 45(5), 848-851.

Aitkenhead, M., Cameron, C., Gaskin, G., Choisy, B., Coull, M., Black, H., 2018. Digital RGB photography and visible-range spectroscopy for soil composition analysis. Geoderma. 313, 265-275.

Alewell, C., Borrelli, P., Meusburger, K., Panagos, P., 2019. Using the USLE: Chances, challenges and limitations of soil erosion modelling. International Soil and Water Conservation Research. 7(3), 203-225.

Almajmaie, A., Hardie, M., Acuna, T., Birch, C., 2017. Evaluation of methods for determining soil aggregate stability. Soil and Tillage Research. 167, 39-45. Angst, G., Mueller, K.E., Kögel-Knabner, I., Freeman, K.H., Mueller, C.W., 2017. Aggregation controls the stability of lignin and lipids in clay-sized particulate and mineral associated organic matter. Biogeochemistry. 132(3), 307-324.

Annabi, M., Raclot, D., Bahri, H., Bailly, J.S., Gomez, C., Le Bissonnais, Y., 2017. Spatial variability of soil aggregate stability at the scale of an agricultural region in Tunisia. Catena. 153, 157-167.

Asano, M., Wagai, R., 2014. Evidence of aggregate hierarchy at micro- to submicron scales in an allophanic Andisol. Geoderma. 216, 62-74.

Bagagiolo, G., Biddoccu, M., Rabino, D., Cavallo, E., 2018. Effects of rows arrangement, soil management, and rainfall characteristics on water and soil losses in Italian sloping vineyards. Environmental Research. 166, 690-704.

Barto, E. K., Alt, F., Oelmann, Y., Wilcke, W., Rillig, M. C., 2010. Contributions of biotic and abiotic factors to soil aggregation across a land use gradient. Soil Biology and Biochemistry. 42(12), 2316-2324.

Ben-Dor, E., Goldlshleger, N., Benyamini, Y., Agassi, M., Blumberg, D.G., 2003. The Spectral Reflectance Properties of Soil Structural Crusts in the 1.2-

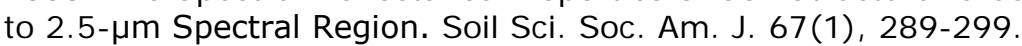

Ben-Dor, E., Patkin, K., Banin, A., Karnieli, A., 2002. Mapping of several soil properties using DAIS-7915 hyperspectral scanner data - a case study over clayey soils in Israel. International Journal of Remote Sensing. 23(6), 10431062.

Bladon, K.D., Bywater-Reyes, S., LeBoldus, J.M., Keriö, S., Segura, C., Ritóková, G., Shaw, D.C., 2019. Increased streamflow in catchments affected by a forest disease epidemic. Science of The Total Environment. 691, 112-123. Borges, J.A.R., Pires, L.F., Cassaro, F.A.M., Roque, W.L., Heck, R.J., Rosa, J. A., Wolf, F.G., 2018. X-ray microtomography analysis of representative elementary volume (REV) of soil morphological and geometrical properties. Soil \& Tillage Research. 182, 112-122.

Borrelli, P., Meusburger, K., Ballabio, C., Panagos, P., Alewell, C., 2018. Object-oriented soil erosion modelling: A possible paradigm shift from potential 
to actual risk assessments in agricultural environments. Land Degradation \& Development. 29(4), 1270-1281.

Borrelli, P., Robinson, D.A., Fleischer, L.R., Lugato, E., Ballabio, C., Alewell, C., Meusburger, K., Modugno, S., Schuett, B., Ferro, V., Bagarello, V., Van Oost, K., Montanarella, L., Panagos, P., 2017. An assessment of the global impact of 21 st century land use change on soil erosion. Nature Communications. 8.

Bottinelli, N., Angers, D.A., Hallaire, V., Michot, D., Le Guillou, C., Cluzeau, D., Heddadj, D., Menasseri-Aubry, S., 2017. Tillage and fertilization practices affect soil aggregate stability in a Humic Cambisol of Northwest France. Soil and Tillage Research. 170, 14-17.

Bracken, L.J., Turnbull, L., Wainwright, J., Bogaart, P., 2015. Sediment connectivity: a framework for understanding sediment transfer at multiple scales. Earth Surface Processes and Landforms. 40(2), 177-188.

Bravo-Garza, M.R., Bryan, R.B., Voroney, P., 2009. Influence of wetting and drying cycles and maize residue addition on the formation of water stable aggregates in Vertisols. Geoderma. 151(3), 150-156.

Buchmann, C., Schaumann, G.E., 2017. Effect of water entrapment by a hydrogel on the microstructural stability of artificial soils with various clay content. Plant and Soil. 414(1-2), 181-198.

Buchmann, C., Schaumann, G.E., 2018. The contribution of various organic matter fractions to soil-water interactions and structural stability of an agriculturally cultivated soil. J ournal of Plant Nutrition and Soil Science. 181(4), 586-599.

Cai, J.Y., Zhou, Z.H., Liu, J.J., Wang, H., Jia, Y. W., Xu, C.Y., 2019. A threeprocess-based distributed soil erosion model at catchment scale on the Loess Plateau of China. J ournal of Hydrology. 578, 12.

Cerda, A., 2000. Aggregate stability against water forces under different climates on agriculture land and scrubland in southern Bolivia. Soil \& Tillage Research. 57(3), 159-166.

Cerdà, A., Rodrigo-Comino, J ., 2020. Is the hillslope position relevant for runoff and soil loss activation under high rainfall conditions in vineyards? Ecohydrology \& Hydrobiology. 20(1), 59-72.

Cerdan, O., Souchère, V., Lecomte, V., Couturier, A., Le Bissonnais, Y., 2002. Incorporating soil surface crusting processes in an expert-based runoff model: Sealing and Transfer by Runoff and Erosion related to Agricultural Management. Catena. 46(2-3), 189-205.

Chen, C., Sparks, D.L., 2015. Multi-elemental scanning transmission X-ray microscopy-near edge X-ray absorption fine structure spectroscopy assessment of organo-mineral associations in soils from reduced environments. Environmental Chemistry. 12(1), 64-73.

Churchman, G.J., 2018. Game Changer in Soil Science. Functional role of clay minerals in soil. Journal of Plant Nutrition and Soil Science. 181(1), 99-103.

de Jong, S.M., 1992. The analysis of spectroscopical data to map soil types and soil crusts of Mediterranean eroded soils. Soil Technology. 5(3): 199-211.

Denef, K., Six, J., Merckx, R., Paustian, K., 2002. Short-term effects of biological and physical forces on aggregate formation in soils with different clay mineralogy. Plant and Soil. 246(2): 185-200.

Deviren Saygın, S., Cornelis, W.M., Erpul, G., Gabriels, D., 2012. Comparison of different aggregate stability approaches for loamy sand soils. Applied Soil Ecology. 54, 1-6. 
Eekhout, J.P.C., de Vente, J., 2019. Assessing the effectiveness of Sustainable Land Management for large-scale climate change adaptation. Science of The Total Environment. 654, 85-93.

Erktan, A., Legout, C., De Danieli, S., Daumergue, N., Cécillon, L., 2016. Comparison of infrared spectroscopy and laser granulometry as alternative methods to estimate soil aggregate stability in Mediterranean badlands. Geoderma. 271, 225-233.

Eshel, G., Levy, G.J., Singer, M.J., 2004. Spectral reflectance properties of crusted soils under solar illumination. Soil Science Society of America Journal. 68(6), 1982-1991.

European Commission, 2018. Sustainable development in the European Union -Monitoring report on progress towards the SDGs in an EU context - 2018 edition.

Fernández-Raga, M., Palencia, C., Keesstra, S., Jordán, A., Fraile, R., AnguloMartínez, M., Cerdà, A., 2017. Splash erosion: A review with unanswered questions. Earth-Science Reviews. 171, 463-477.

Fernández, C., Vega, J.A., 2018. Evaluation of the rusle and disturbed wepp erosion models for predicting soil loss in the first year after wildfire in NW Spain. Environmental Research. 165, 279-285.

Forkuor, G., Hounkpatin, O.K.L., Welp, G., Thiel, M., 2017. High Resolution Mapping of Soil Properties Using Remote Sensing Variables in South-Western Burkina Faso: A Comparison of Machine Learning and Multiple Linear Regression Models. PLOS ONE. 12(1), e0170478.

Gholizadeh, A., Saberioon, M., Viscarra Rossel, R.A., Boruvka, L., Klement, A., 2020. Spectroscopic measurements and imaging of soil colour for field scale estimation of soil organic carbon. Geoderma. 357, 113972.

Goldshleger, N., Ben-Dor, E., Benyamini, Y., Agassi, M., 2004. Soil reflectance as a tool for assessing physical crust arrangement of four typical soils in Israel. Soil Science. 169(10), 677-687.

Gomez, C., Lagacherie, P., Coulouma, G., 2008. Continuum removal versus PLSR method for clay and calcium carbonate content estimation from laboratory and airborne hyperspectral measurements. Geoderma. 148(2), 141-148.

GSP., 2017. Global Soil Partnership Endorses Guidelines on Sustainable Soil Management. Rome, Italy, FAO.

Guo, L., Zhang, H., Shi, T., Chen, Y., Jiang, Q., Linderman, M., 2019. Prediction of soil organic carbon stock by laboratory spectral data and airborne hyperspectral images. Geoderma. 337, 32-41.

ITPS., 2015. State of the World's Soil Resources. Rome, Italy, FAO.

Jarvis, N., Larsbo, M., Koestel, J., 2017. Connectivity and percolation of structural pore networks in a cultivated silt loam soil quantified by X-ray tomography. Geoderma. 287, 71-79.

Kaiser, K., Guggenberger, G., 2003. Mineral surfaces and soil organic matter. European J ournal of Soil Science. 54(2), 219-236.

Kaiser, K., Guggenberger, G., 2007. Distribution of hydrous aluminium and iron over density fractions depends on organic matter load and ultrasonic dispersion. Geoderma. 140(1-2), 140-146.

Khayamim, F., Wetterlind, J., Khademi, H., Robertson, A.H.J., Cano, A. F., Stenberg, B., 2015. Using visible and near infrared spectroscopy to estimate carbonates and gypsum in soils in arid and subhumid regions of Isfahan, Iran. J ournal of near Infrared Spectroscopy. 23(3), 155-165. 
Kögel-Knabner, I., Guggenberger, G., Kleber, M., Kandeler, E., Kalbitz, K., Scheu, S., Eusterhues, K., Leinweber, P., 2008. Organo-mineral associations in temperate soils: Integrating biology, mineralogy, and organic matter chemistry. J ournal of Plant Nutrition and Soil Science. 171(1), 61-82.

Koiter, A.J., Owens, P.N., Petticrew, E.L., Lobb, D.A., 2017. The role of soil surface properties on the particle size and carbon selectivity of interrill erosion in agricultural landscapes. Catena. 153, 194-206.

Kuhn, N.J., 2007. Erodibility of soil and organic matter: independence of organic matter resistance to interrill erosion. Earth Surface Processes and Landforms. 32(5), 794-802.

Lal, R., 2018. Saving global land resources by enhancing eco-efficiency of agroecosystems. Journal of Soil and Water Conservation. 73(4), 100A-106A.

Le Bissonnais, Y., 1996. Aggregate stability and assessment of soil crustability and erodibility: I. Theory and methodology Stabilité structurale et évaluation de la sensibilité des sols à la battance et à l'érosion: I: Théorie et méthologie. European J ournal of Soil Science. 47(4), 425-437.

Lehtinen, T., Lair, G.J., Mentler, A., Gisladottir, G., Ragnarsdottir, K.V., Blum, W.E.H., 2014. Soil Aggregate Stability in Different Soil Orders Quantified by Low Dispersive Ultrasonic Energy Levels. Soil Science Society of America Journal. 78(3), 713-723.

Levin, N., Ben-Dor, E., Singer, A., 2005. A digital camera as a tool to measure colour indices and related properties of sandy soils in semi-arid environments. International J ournal of Remote Sensing. 26(24), 5475-5492.

Montanarella, L., Pennock, D.J., McKenzie, N., Badraoui, M., Chude, V., Baptista, I., Mamo, T., Yemefack, M., Aulakh, M.S., Yagi, K., Hong, S.Y., Vijarnsorn, P., Zhang, G.L., Arrouays, D., Black, H., Krasilnikov, P., Sobocka, J., Alegre, J., Henriquez, C.R., Mendonca-Santos, M.d.L., Taboada, M., Espinosa-Victoria, D., AlShankiti, A., AlaviPanah, S.K., Elsheikh, E.A.E.M., Hempel, J., Arbestain, M.C., Nachtergaele, F., Vargas, R., 2016. World's soils are under threat. Soil. 2(1), 79-82.

Mulder, V.L., de Bruin, S., Schaepman, M.E., Mayr, T.R., 2011. The use of remote sensing in soil and terrain mapping - A review. Geoderma. 162(1-2), 1- 19.

Oldeman LR, H.R., Sombroeck, W.G., 1991. World Map of the Status of Human Induced Soil Degradation: An Explanatory Note. Wageningen, The Netherlands, ISRIC: 34.

Ozturk, T., Ceber, Z.P., Türkeş, M., Kurnaz, M.L., 2015. Projections of climate change in the Mediterranean Basin by using downscaled global climate model outputs. International J ournal of Climatology. 35(14), 4276-4292.

Paradelo, M., Katuwal, S., Moldrup, P., Norgaard, T., Herath, L., de Jonge, L. W., 2016. X-ray CT-Derived Soil Characteristics Explain Varying Air, Water, and Solute Transport Properties across a Loamy Field. Vadose Zone Journal. 15(4), vzj2015.2007.0104.

Peng, X., Yan, X., Zhou, H., Zhang, Y.Z., Sun, H., 2015. Assessing the contributions of sesquioxides and soil organic matter to aggregation in an Ultisol under long-term fertilization. Soil and Tillage Research. 146, 89-98.

Pires, L.F., Villanueva, F.C.A., Dias, N.M.P., Bacchi, O.O.S., Reichardt, K., 2011. Chemical migration during soil water retention curve evaluation. Anais da Academia Brasileira de Ciencias. 83(3), 1097-1107.

Poehlitz, J., Ruecknagel, J., Schlueter, S., Vogel, H.J., Christen, O., 2019. Computed tomography as an extension of classical methods in the analysis of 
soil compaction, exemplified on samples from two tillage treatments and at two moisture tensions. Geoderma. 346, 52-62.

Praskievicz, S., 2016. Modeling hillslope sediment yield using rainfall simulator field experiments and partial least squares regression: Cahaba River watershed, Alabama (USA). Environmental Earth Sciences. 75(19), 1324.

Rabot, E., Wiesmeier, M., Schlüter, S., Vogel, H.J., 2018. Soil structure as an indicator of soil functions: A review. Geoderma. 314, 122-137.

Rather, M.A., Kumar, J.S., Farooq, M., Rashid, H., 2017. Assessing the influence of watershed characteristics on soil erosion susceptibility of J helum basin in Kashmir Himalayas. Arabian J ournal of Geosciences. 10(3).

Regelink, I.C., Stoof, C.R., Rousseva, S., Weng, L., Lair, G.J., Kram, P., Nikolaidis, N.P., Kercheva, M., Banwart, S., Comans, R.N.J., 2015. Linkages between aggregate formation, porosity and soil chemical properties. Geoderma. 247-248, 24-37.

Rivera, J.I., Bonilla, C.A. 2020. Predicting soil aggregate stability using readily available soil properties and machine learning techniques. Catena. 187, 104408.

Rossel, R.A.V., Cattle, S.R., Ortega, A., Fouad, Y., 2009. In situ measurements of soil colour, mineral composition and clay content by vis-NIR spectroscopy. Geoderma. 150(3-4), 253-266.

Schlüter, S., Sheppard, A., Brown, K., Wildenschild, D., 2014. Image processing of multiphase images obtained via X-ray microtomography: A review. Water Resources Research. 50(4), 3615-3639.

Schlüter, S., Vogel, H.J ., 2016. Analysis of Soil Structure Turnover with Garnet Particles and X-Ray Microtomography. Plos One. 11(7), e0159948.

Shrestha, D.P., Suriyaprasit, M., Prachansri, S., 2014. Assessing soil erosion in inaccessible mountainous areas in the tropics: The use of land cover and topographic parameters in a case study in Thailand. Catena. 121, 40-52.

Sollins, P., Kramer, M.G., Swanston, C., Lajtha, K., Filley, T., Aufdenkampe, A.K., Wagai, R., Bowden, R.D., 2009. Sequential density fractionation across soils of contrasting mineralogy: evidence for both microbial- and mineralcontrolled soil organic matter stabilization. Biogeochemistry. 96(1-3), 209231.

Stenberg, B., 2010. Effects of soil sample pretreatments and standardised rewetting as interacted with sand classes on Vis-NIR predictions of clay and soil organic carbon. Geoderma. 158(1-2), 15-22.

Stoppe, N., Horn, R., 2018. Microstructural strength of tidal soils - a rheometric approach to develop pedotransfer functions. Journal of Hydrology and Hydromechanics. 66(1), 87-96.

Teng, H., Rossel, R.A.V., Shi, Z., Behrens, T., Chappell, A., Bui, E., 2016. Assimilating satellite imagery and visible-near infrared spectroscopy to model and map soil loss by water erosion in Australia. Environmental Modelling \& Software. 77, 156-167.

Torres-Sallan, G., Schulte, R.P.O., Lanigan, G.J., Byrne, K.A., Reidy, B., Simo, I., Six, J., Creamer, R.E., 2017. Clay illuviation provides a longterm sink for C sequestration in subsoils. Scientific Reports. 7.

Totsche, K.U., Amelung, W., Gerzabek, M.H., Guggenberger, G., Klumpp, E., Knief, C., Lehndorff, E., Mikutta, R., Peth, S., Prechtel, A., Ray, N.KögelKnabner, I., 2018. Microaggregates in soils. Journal of Plant Nutrition and Soil Science. 181(1), 104-136.

USDA., 1999. Soil Taxonomy: A Basic System of Soil Classification for Making 
and Interpreting Soil Surveys. S. Edition. USA, The United States Department of Agriculture.

Viscarra-Rossel, R.A., Walvoort, D.J.J., Mcbratney, A.B., Janik, L.J., \& Skjemstad, J.O., 2006. Visible, near infrared, mid infrared or combined diffuse reflectance spectroscopy for simultaneous assessment of various soil properties. Geoderma. 131, 59-75.

Viscarra Rossel, R.A., Behrens, T., Ben-Dor, E., Brown, D.J., Demattê, J.A. M., Shepherd, K.D., Shi, Z., Stenberg, B., Stevens, A., Adamchuk, V., Aïchi, H., Barthès, B.G., Bartholomeus, H.M., Bayer, A.D., Bernoux, M., Böttcher, K., Brodský, L., Du, C.W., Chappell, A., Fouad, Y., Genot, V., Gomez, C., Grunwald, S., Gubler, A., Guerrero, C., Hedley, C.B., Knadel, M., Morrás, H. J.M., Nocita, M., Ramirez-Lopez, L., Roudier, P., Campos, E.M.R., Sanborn, P., Sellitto, V.M., Sudduth, K.A., Rawlins, B.G., Walter, C., Winowiecki, L. A., Hong, S.Y., Ji, W., 2016. A global spectral library to characterize the world's soil. Earth-Science Reviews. 155, 198-230.

Viscarra Rossel, R.A., Fouad, Y., Walter, C., 2008. Using a digital camera to measure soil organic carbon and iron contents. Biosystems Engineering. 100(2), 149-159.

Wairiul, M., 2017. Land degradation and sustainable land management practices in Pacific Island Countries. Regional Environmental Change. 17(4), 1053-1064.

Wendling, B., J ucksch, I., Mendonca, E.D., Neves, J.C.L., 2005. Organic carbon and aggregate stability of a Red Latossol under different managements. Pesquisa Agropecuaria Brasileira. 40(5), 487-494.

Wu, C.W., Yang, Y., Xia, J.X., 2017. A simple digital imaging method for estimating black-soil organic matter under visible spectrum. Archives of Agronomy and Soil Science. 63(10), 1346-1354.

Xu, L., Zheng, C.L., Wang, Z.C., Nyongesah, M.J., 2019. A digital camera as an alternative tool for estimating soil salinity and soil surface roughness. Geoderma. 341, 68-75.

Xue, B., Huang, L., Huang, Y., Zhou, F., Li, F., Kubar, K.A., Li, X., Lu, J., Zhu, J. 2019. Roles of soil organic carbon and iron oxides on aggregate formation and stability in two paddy soils. Soil and Tillage Research. 187, 161-171. 
2 Soil sampling, data preparation and lab analysis methods 


\subsection{Field data collection}

To achieve research objectives and find answers to the research questions described in chapter 1 , soil samples were collected in the Netherlands for the application of proximal remote sensing techniques at laboratory conditions (Figure. 2-1). Samples were collected from 2 locations: (i) Limburg, where loess is the primary soil type and (ii) in Deventer, where sand is predominant. During the Pleistocene, the marine sediments adapted a continental character due to the regression (Vos and Knol, 2015). The Rhine, Meuse and Scheldt river systems left thick layers of coarse sediments (sand and gravel) while extending westwards (Ebbing et al., 2003). Simultaneously, the eolian sediments were deposited in the southern parts of the Netherlands (Veer, 2006). Moreover, the wind-blown deposits formed the loess in the southeast of Limburg and the sand in the south and east of the Netherlands during the last glacial period. Nevertheless, the soil formation started after the glacial period when the temperature rose and the vegetation was present. The division of the soil types in the Netherlands consists of marine clay, peatland, sandy area and the loess district.

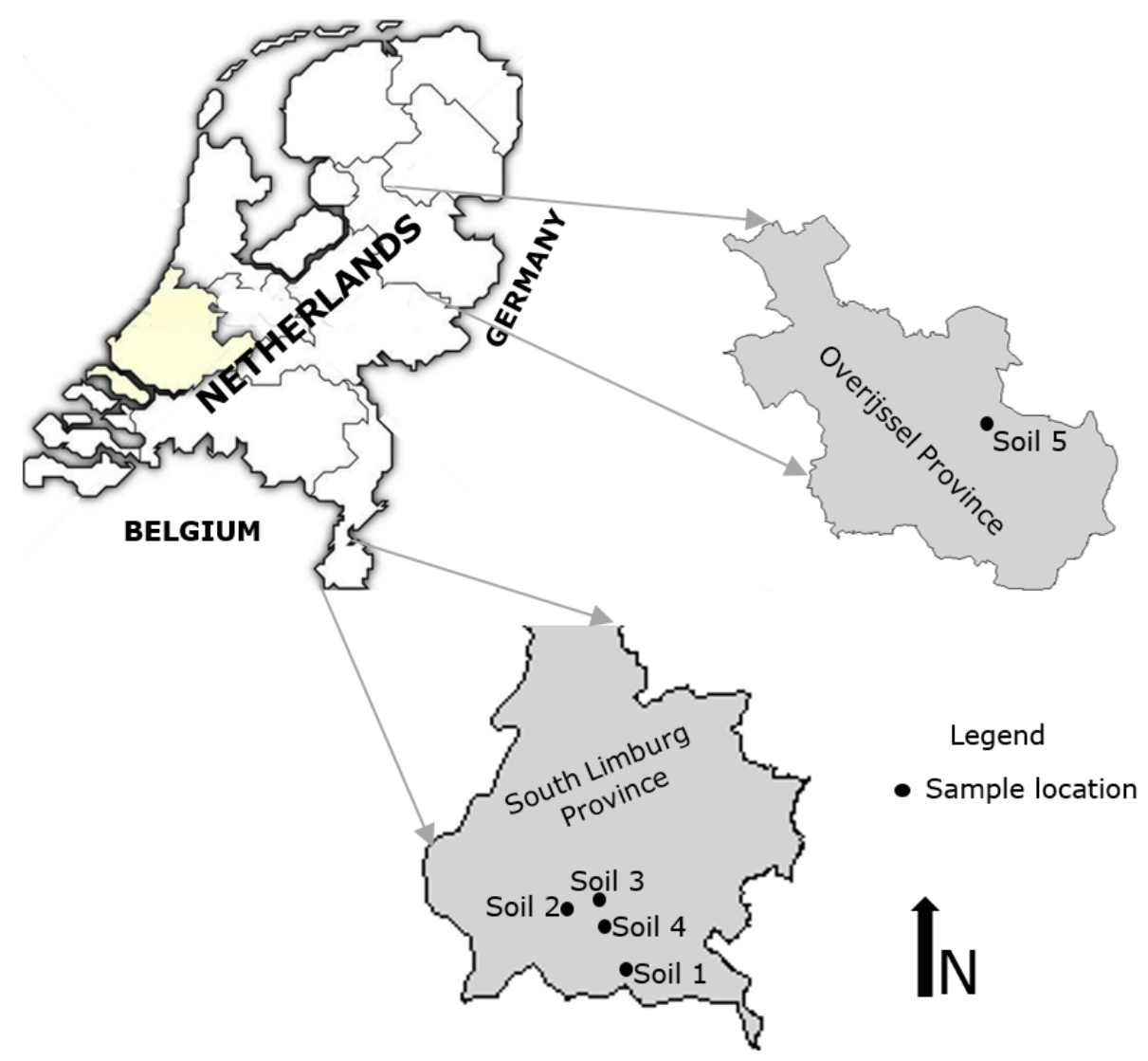


Figure 2-1. The soil samples collected in south Limburg and Overijssel provinces in the Netherlands. Silty Loam and Loam soil samples (Soil 1-Soil 4) were collected in the loess area, and the Sandy Loam sample (Soil 5) was collected in the sandy area in the east. The location of the soil samples is shown with a black dot. (schematic of the Netherlands maps are modified after (https://gadm.org/)

\subsubsection{Data collected in Limburg}

Loess soils are prone to slaking and very susceptible to water erosion due to their weak structure and low organic matter content. The intensive agriculture in the loess area has increased the magnitude and the frequency of soil erosion. The need to upscale the agricultural fields lead to a decrease in the grassland area. Moreover, due to agricultural practices, soil compaction takes place. Consequently, a decrease in water storage capacity and an increase in surface runoff occurs (Winteraeken and Spaan, 2010). Likewise, the use of artificial fertilizers affects the organic matter negatively, contributing to the degradation of soil structure. Furthermore, considering the climate change with wetter winter and summer with dry periods and intensive rain showers, soil erosion in the future might be even more problematic in the loess area (Ward et al., 2008).

Southern Limburg has a mild topography with elevation from $40 \mathrm{~m}$ to $320 \mathrm{~m}$ above sea level. The hills are covered with a loess (aeolian silt) layer. In their silt fraction, these loess soils contain more than $70 \%$ quartz, and they are rich in lime. Moreover, the loess soil profile consists of a till layer with low organic matter content and a subsurface horizon with a weak platy structure (Sevink and Verstraten, 1979). South Limburg has a temperate oceanic climate with an average annual precipitation of $750 \mathrm{~mm}$. Although the rainfall is recorded in all seasons, the high-intensity rainfall occurs during April-October. The land use in the south of Limburg is mostly agriculture with arable crops such as cereals, silage-maize, potatoes and sugar beets.

\subsubsection{Data collected in Deventer}

Besides the four soil samples collected in the southern Limburg, one sample was taken from the sandy area in Deventer, the east of the Netherlands. The characteristic of the sandy area is sandy plateaus crossed by sand and peat stream valleys. This overlap is a result of the peat excavation over the last centuries, which lead to flat areas with sandy soil (Ritzema and Stuyt, 2015). Therefore, the land use is diverse from peri-urban, rural with small agriculture, forest to areas with cultural value. In the east of the Netherlands, the sandy area is characterized by high infiltration and seepage. Usually, agriculture relies on rain. However, when a shortage of rain occurs, groundwater irrigation is applied. 


\subsection{Data preparation}

Field soil samples were transferred on the plastic sheets for air-drying while taking care of the soil labelling to avoid identification errors. Likewise, the soil samples were placed away from direct sunlight. Soil samples air-dried at room temperature conditions for four weeks.

To monitor aggregate breakdown under natural conditions, five plastic trays of $60 \times 40 \times 5.5 \mathrm{~cm}^{3}$ were filled manually with soil using a small shovel. Because of this procedure, soil aggregates of various sizes were randomly distributed. Holes in one side of the tray at the bottom were drilled to enable drainage. Also, pantyhose filters were used to avoid soil leaking out.

To investigate the soil mineralogical changes at different soil moisture conditions (drying-field capacity, field capacity, and waterlogging-field capacity treatments), twenty-seven plastic trays of $15 \times 9 \times 1 \mathrm{~cm}^{3}$ were filled manually with soil using a small shovel. As a result, the soil aggregates of various sizes occurred in the tray. The air-dried soils were weighted using a balance. The deionized water was added carefully at the trays' edge to place them at the field capacity. Moreover, holes at the bottom of the tray to enable drainage were drilled. Likewise, the pantyhose filters were used to avoid the soil leaking out. Another set of soil samples were placed at the waterlogging by saturating them with deionized water. Moreover, to eliminate any external influence on the soil samples, the trays were covered with a plastic lid.

Another experiment was performed to investigate the effect of freeze-thaw cycles on the soil surface mineralogy at the different moisture content (field capacity and waterlogging). Therefore, the soil sample preparation was the same as the previous experiment. Here, twelve plastic trays $\left(15 \times 9 \times 1 \mathrm{~cm}^{3}\right)$ filled with soil were used. While six trays were placed at the field capacity, the other six were put in waterlogging conditions. Afterwards, all the soil samples were placed in the freezer for three days. Next, they were left thawing for the coming three days.

Soil spectral measurements in the laboratory involve air-dried, grinding, and sieved samples and they, are point measurements. However, in our study, the spectral measurements are conducted in soils without any preparation mentioned above.

\subsection{Laboratory analysis of soil samples}

\subsubsection{Soil particle size and organic matter determination}

The soil particle size determination was carried out on fine earth $(<2 \mathrm{~mm}$ ) according to the ISRIC protocol (van Reeuwijk, 2002). First, the organic matter was oxidized with $\mathrm{H}_{2} \mathrm{O}_{2}$. Next, the sand was separated from the clay and silt with a $50 \mu \mathrm{m}$ sieve. The clay and silt fractions were determined with the pipette method based on sampling a 1-litre suspension with a $20 \mathrm{ml}$ pipette. The obtained clay, silt and sand fraction are calculated on a dry-ash-free basis. 
The organic matter was determined by heating the sample at $600{ }^{\circ} \mathrm{C}$ for more than $12 \mathrm{~h}$ and calculating the weight loss on the dry soil.

\subsubsection{Soil aggregate stability tests}

The soil aggregate stability was determined according to the normalized international method ISO 10932 (Le Bissonnais, 1996). This method uses disruptive tests corresponding to various wetting conditions and energies. While the fast wetting (FW) test is related to slaking, the mechanical breakdown (MB) by shaking after pre-wetting represents the process of raindrop impact on soil. The results of these tests are expressed as the mean weight diameter (MWD). Based on the MWD value, the soil aggregate stability classes, very unstable (VUS) $(<0.4 \mathrm{~mm})$, unstable (US) $(0.4-0.8 \mathrm{~mm})$, medium (M) $(0.8-1.3 \mathrm{~mm})$, stable (S) $(1.3-2 \mathrm{~mm})$ and very stable (VS) (> $2 \mathrm{~mm}$ ) were derived. Table 2-1 summarizes the soil characteristics used in this work. The agricultural crop cultivated on all the fields was maize. However, at the time of soil sampling, this crop was already harvested.

Table 2-1. Characteristics of soil samples

\begin{tabular}{|c|c|c|c|c|c|c|c|c|c|}
\hline \multirow[t]{2}{*}{ Soil ID } & \multicolumn{2}{|c|}{ Location (WGS 84) } & \multicolumn{3}{|c|}{$\begin{array}{c}\text { Soil Particle Size } \\
(\%)\end{array}$} & \multirow[t]{2}{*}{$\begin{array}{l}\text { Texture } \\
\text { Class }\end{array}$} & \multirow[t]{2}{*}{$\begin{array}{l}\mathrm{OM} \\
(\%)\end{array}$} & \multicolumn{2}{|c|}{$\begin{array}{l}\text { Aggregate } \\
\text { Stability }\end{array}$} \\
\hline & Lat & Long & Clay & Silt & Sand & & & FW & MB \\
\hline Soil 1 & $50.7758^{\circ}$ & $5.8824^{\circ}$ & 16 & 71 & 13 & Silty Loam & 4.6 & VUS & US \\
\hline Soil 2 & $50.7687^{\circ}$ & $5.9201^{\circ}$ & 23 & 52 & 25 & Silty Loam & 12.3 & US & M \\
\hline Soil 3 & $50.7727^{\circ}$ & $5.9213^{\circ}$ & 22 & 54 & 24 & Silty Loam & 12.5 & US & $M$ \\
\hline Soil 4 & $50.8694^{\circ}$ & $5.7884^{\circ}$ & 17 & 44 & 39 & Loam & 5.6 & US & US \\
\hline Soil 5 & $52.2810^{\circ}$ & $6.1813^{\circ}$ & 14 & 11 & 75 & Sandy Loam & 5.3 & US & US \\
\hline
\end{tabular}

\subsubsection{X-ray diffraction analysis}

The X-ray diffraction analysis was carried out using the clay fraction derived from the pipette method. X-ray analysis identified a range of minerals such as goethite, hematite, maghemite, Mg-clinochlore, ferroan clinochlore, kaolinite and muscovite. These minerals are typical of Luvisols developed on a loess deposit (Veer, 2006). The parent material of these loess soils consists of silty eolian sediments, which determine their mineralogical composition. Exposure of these sediments to the physical and chemical weathering formed secondary minerals such as goethite, hematite, or hematite polymorph with maghemite (Stiboka, 1965). Likewise, quartz and chlorites occur in the fine silt fraction of these loamy sediments (Breeuwsma, 1987). 
Soil sampling, data preparation and lab analysis methods

\subsubsection{Soil spectra measurement with Analytical Spectral Device (ASD)}

The Analytical Spectral Device (ASD Boulder, USA) spectroradiometer acquiring data in the $350 \mathrm{~nm}$ to $2500 \mathrm{~nm}$ spectral range with a spectral interval of $1.4 \mathrm{~nm}$ in VNIR (350-1000 nm) was used to measure the spectra of the soil samples. These measurements were performed under controlled dark conditions, using a 512-channel silicon photodiode array. After the white reference optimization, an average spectrum of the soil samples was obtained.

\subsubsection{Inductivity Coupled Plasma-Optical Emission Spectrometry Instruments (ICP-OES) measurements}

The Inductivity Coupled Plasma-Optical Emission Spectrometry Instruments (ICP-OES) technique measures the concentration of chemical elements in a solution applying a linear approach (element concentration vs light intensity) (PerkinElmer, 2018). The excess water was collected to investigate the soil samples' losses of soluble elements placed at different moisture conditions (see chapter 3). Using the ICP-OES technique, the $\mathrm{Mg}, \mathrm{Al}, \mathrm{Ca}, \mathrm{K}$, and $\mathrm{Na}$ concentration was determined for each soil sample.

\subsection{References}

Breeuwsma., 1987. De mineralogische samenstelling van zand- en kleigronden. Bodemkunde van Nederland, deel 1: Algemene bodemkunde. Stichting voor Bodemkartering (Stiboka). Malmberg, Den Bosch, The Netherlands.

Ebbing, J.H.J., Weerts, H.J.T., Westerhoff, W.E., 2003. Towards an integrated land-sea stratigraphy of the Netherlands. Quaternary Science Reviews. 22(1517), 1579-1587.

Le Bissonnais, Y., 1996. Aggregate stability and assessment of soil crustability and erodibility: I. Theory and methodology Stabilité structurale et évaluation de la sensibilité des sols à la battance et à l'érosion: I: Théorie et méthologie. European J ournal of Soil Science. 47(4), 425-437.

PerkinElmer, I., 2018. Sensitivity, Background, Noise, and Calibration in Atomic Spectroscopy: Effects on Accuracy and Detection Limits. 1-11.

Ritzema, H.P., Stuyt, L.C.P.M., 2015. Land drainage strategies to cope with climate change in the Netherlands. Acta Agriculturae Scandinavica, Section B - Soil \& Plant Science. 65(sup1), 80-92.

Sevink, J., Verstraten, J.M., 1979. Clay soils on limestone in South Limburg, The Netherlands, 1. Setting and general characteristics. Geoderma. 21(4), 251-267.

Stiboka., 1965. De Bodem van Nederland: Toelichting bij de Bodemkaart van Nederland, schaal 1:200000. Wageningen, The Netherlands, Centre for Agricultural Publishing and Documentation: (Stichting Bodem Kartering). 
van Reeuwijk, L.P., 2002. Procedures for soil analysis. Technical Paper No. 9. t. edition. Droevendaalsesteeg 3, 6708 PB Wageningen, The Netherlands, ISRIC, Wageningen.

Veer, G.v.d., 2006. Geochemical soil survey of the Netherlands. PhD, Utrecht University

Vos, P.C., Knol, E., 2015. Holocene landscape reconstruction of the Wadden Sea area between Marsdiep and Weser. Netherlands J ournal of GeosciencesGeologie En Mijnbouw. 94(2).

Ward, P.J., Renssen, H., Aerts, J.C.J.H., van Balen, R.T., Vandenberghe, J., 2008. Strong increases in flood frequency and discharge of the River Meuse over the late Holocene: impacts of long-term anthropogenic land use change and climate variability. Hydrology and Earth System Sciences. 12(1), 159-175. Winteraeken, H.J., Spaan, W.P., 2010. A new approach to soil erosion and runoff in south Limburg-THE Netherlands. Land Degradation \& Development. 21(4), 346-352. 
Soil sampling, data preparation and lab analysis methods 


\section{Monitoring soil surface mineralogy at different moisture conditions using Visible Near-Infrared spectroscopy data*}

\footnotetext{
*This chapter is based on: Ymeti, I.; Shrestha, D.P.; van der Meer, F. Monitoring Soil Surface Mineralogy at Different Moisture Conditions Using Visible Near-I nfrared Spectroscopy Data. Remote Sensing. 2019, 11, 2526
} 
Monitoring soil surface mineralogy at different moisture conditions using Visible Near$\underline{\text { Infrared spectroscopy data }}$

\begin{abstract}
Soil minerals determine essential soil properties such as cation exchange capacity, texture, structure, and their capacity to form bonds with organic matter. Any alteration of these organo-mineral interactions to climate change needs to be identified. Visible Near-Infrared imaging spectroscopy is capable of assessing spectral soil constituents that are responsible for organomineral interactions. In this study, it is hypothesized that alterations of soil mineralogy occur due to moisture variations. For eight weeks, under laboratory conditions, imaging spectroscopy data were collected on a 72 hours basis for three Silty Loam soils varying in organic matter (without, low and high) placed at drying-field capacity, field capacity and waterlogging-field capacity treatments. Using Spectral Information Divergence image classifier, the image area occupied by Mg-clinochlore, goethite, quartz coated $50 \%$ by goethite, hematite dimorphous with maghemite was detected and quantified (percentage). The results showed that these minerals behaved differently, depending on the soil type and soil treatment. While for the soils with organic matter, the mineralogical alterations were evident at field capacity state, for the one with no organic matter, these changes were insignificant. Using imaging spectroscopy data, it is shown that the Silty Loam soil mineralogy changes over time due to moisture conditions.
\end{abstract}

\title{
3.1 Introduction
}

Soil minerals vary extensively in their composition, crystallinity and charge characteristics. Therefore, they determine essential soil properties such as cation exchange capacity (CEC), texture, structure, and their capacity to form bonds with organic matter (OM). The mobilization and precipitation of cations such as $\mathrm{Si}^{4+}, \mathrm{Fe}^{3+}, \mathrm{Al}^{3+}, \mathrm{Mg}^{2+}$ and $\mathrm{Ca}^{2+}$ can promote the disaggregation and breakdown of soil aggregates as well as the formation of new ones. Soils containing polyvalent cations such as $\mathrm{Ca}^{2+}, \mathrm{Al}^{3+}$ and $\mathrm{Fe}^{3+}$ are resistant to slaking (Chan and Heenan, 1999; Breuer and Schwertmann, 1999). Indeed, the interactions between the mineral particles and OM in soil depend on the concentration of these cations (Kaiser et al., 2012). I ron hydroxides such as goethite, hematite, or maghemite can interact with both clay minerals and organic compounds to form clay-mineral-organic associations, acting as binding and cementing agents in soil (Kogel-Knabner et al., 2008; Martins et al., 2013). Moreover, the amorphous iron oxides, are more effective than crystalline Fe oxides in stabilizing soil, due to their large and reactive surface area (Duiker et al., 2003).

The other divalent cation, $\mathrm{Mg}^{2+}$, has an excellent hydration radius, which enables the soil to absorb more water (Zhang and Norton, 2002). As a result, the van der Waals forces that hold the soil particles together weaken, affecting the soil structure. Recently, in their review, Totsche et al., (2018) pointed out that few studies have considered the effect of the mineral composition on the formation and turnover of micro-aggregates. Using a linear regression model for analyzing biotic and abiotic contributions to soil stability, Barto et al., (2010) found that the abiotic factors played a more critical role in determining soil stability than did biotic factors. Moreover, recent studies have shown that iron hydroxides and clay particles are the dominant mechanisms for soil formation at the microscale $(<250 \mu \mathrm{m}$ ) (Falsone et al., 2016; Regelink et al., 
2015). The interactions of organo-mineral hydroxide, organo-phyllosilicate clay mineral and phyllosilicate-hydroxide mineral occurring in soil vary with mineral structure, soil solution ionic strength, and $\mathrm{pH}$ (Qafoku, 2015). Any alteration of these organo-mineral interactions to climate change needs to be identified (Kleber et al., 2015).

Imaging spectroscopy operating in visible, near-infrared and shortwave infrared (VNIR-SWIR) regions of the electromagnetic spectrum can assess several soil properties such as OM, iron, clay, calcium carbonate (Gomez et al., 2015; Richter et al., 2009; Xie et al., 2012). To quantify the mineralogical abundances of complex soil mixtures at wavelength region, 2100-2400 nm, Mulder et al., (2013) combined absorption features parametrized by exponential Gaussian optimization with the regression tree approach. They have shown that SWIR spectra (2100-2400 nm) may be used for quantifying the mineral abundance of complex soil mixtures. Another study used proximal remote sensing in the VNIR-SWIR and mid-infrared (MIR) region to estimate weathering indices (Mohanty et al., 2016). These indices express the molar ratios of immobile to mobile mineral oxides present in the soil. Using partial least squared regression (PLSR) approach for spectral calibration and prediction, they reported that the best weathering index predictions were derived when VNIR-SWIR and MIR were combined, and significant spectral features selected for analysis. Also, knowing that many spectrally active soil constituents are responsible for soil aggregation, Sarathjith et al., (2014) combined the PLSR approach with Diffuse Reflectance Spectroscopy to estimate soil aggregate characteristics such as the Geometric Mean Diameter which is a quantitative descriptor of soil structure. Their results showed that the geometric mean diameter and the median aggregate size parameters provided good predictions with the ratio of performance deviation (RPD) values ranging from 1,99 to 2,28 .

VNIR imaging spectroscopy is capable of assessing spectral soil constituents, that are responsible for organo-mineral interactions. These interaction mechanisms occurring naturally in soil depend not only on soil mineralogy and their reactive surface area, soil type and soil texture but also on climate change. However, there is limited knowledge of soil mineralogical behaviour at different moisture content occurring in a short period. Therefore, in this study, is hypothesized that alterations of soil mineralogy occur due to moisture variations. To test this hypothesis, Silty Loam soil samples varying in organic matter (no, low and high), under drying-field capacity, field capacity and waterlogging state were scanned in laboratory conditions at a micro-plot scale at 72 hours basis using an imaging spectrometer camera for eight weeks.

\subsection{Materials and Methods}

\subsubsection{Experimental setup}

Silty Loam soils with various OM contents and added hematite were exposed to different soil moisture conditions to study their mineralogical changes over time. A laboratory experiment consisting of an imaging spectrometer camera, a light source and a sliding table integrated into a fixed setup was designed. Also, on the sliding table, a tray filled with soil was placed. Two soil samples, 
Monitoring soil surface mineralogy at different moisture conditions using Visible NearInfrared spectroscopy data

Silty Loam with low and high OM content (Soil 2 and Soil 3), were collected from topsoil $(20 \mathrm{~cm})$ of two different agricultural fields in Limburg, the Netherlands. The agricultural crop cultivated in both fields was maize. However, at the time of soil sampling, this crop was already harvested. These soil samples were collected at the end of September 2014. The Silty Loam soils were chosen because they have low aggregate stability (Ymeti et al., 2017). The other soil sample was obtained by destroying the OM of Soil 2 by heating it at $550{ }^{\circ} \mathrm{C}$ for at least $12 \mathrm{~h}$. The new soil sample without OM was mixed manually with hematite $0.5 \%$ concentration obtaining Soil 1 . Besides the loss of $\mathrm{OM}$ at $550{ }^{\circ} \mathrm{C}$, clay mineral kaolinite decomposes above this temperature leading to amorphous alumino-silicate material (Zavala et al., 2010). Likewise, soil mineral goethite transforms to hematite or maghemite at the temperature ranging from $250{ }^{\circ} \mathrm{C}$ to $420{ }^{\circ} \mathrm{C}$ (Hanesch et al., 2006; Liu et al., 2013). However, these mineralogical alterations of Soil 1 were out the scope of this study. Each of these soil samples was triplicated. Table 3-1 summarized the soil characteristics used in this study.

Table 3-1. The soils used in this study. Soils 2-3 (low and high OM) were collected from Limburg province in the Netherlands. Soil 1 (no OM and added hematite) was obtained from Soil 2.

\begin{tabular}{cllllcc}
\hline Soil ID & \multicolumn{2}{l}{ Soil particle size (\%) } & Texture class & $\mathrm{OM}(\%)$ & $\mathrm{Fe}_{2} \mathrm{O}_{3}(\%)$ \\
& Clay & Silt & Sand & & \\
\hline Soil 1 & 16 & 71 & $13^{1}$ & Silty Loam & 0 & 0.5 \\
Soil 2 & 16 & 71 & 13 & Silty Loam & $4.6^{2}$ & $\mathrm{Na}^{4}$ \\
Soil 3 & 23 & 52 & 25 & Silty Loam & $12.3^{3}$ & $\mathrm{Na}$ \\
\hline
\end{tabular}

${ }^{1}$ The determination of soil particle size was only performed before the soil sample was placed at $550{ }^{\circ} \mathrm{C}$.

${ }^{2}$ The OM was determined by heating the sample at $550{ }^{\circ} \mathrm{C}$ for more than $12 \mathrm{~h}$ and calculating the weight loss on the dry soil.

${ }^{3}$ The high OM content in Soil 3 is probably coming from sewage sludge manure mixed with plant residues application by the farmer some days before soil sample was taken.

${ }^{4}$ Not applicable

Soil samples were air-dried at room conditions for four weeks. Since the goal was to investigate soil mineralogical weathering at different soil moisture conditions, twenty-seven plastic trays of $15 \times 9 \times 1 \mathrm{~cm}^{3}$ were filled manually with soil using a small shovel. Because of this procedure, soil aggregates of various sizes were randomly placed. In this study, three soil treatments; drying-field capacity (D-FC), field capacity (FC) and waterlogging-field capacity (W-FC), were considered as separate setups. Therefore, each soil treatment had its own set of soil samples triplicated (Soil 1 - Soil 3). Deionized water was added carefully at the edge of the trays to place the air-dried soil samples at field capacity and waterlogging conditions. The amount of water required for this procedure was different, depending on the soil type.

At D-FC soil treatment, nine soil samples experienced repeated cycles of drying and field capacity. First, the soil samples were placed in an oven at $40{ }^{\circ} \mathrm{C}$ for $72 \mathrm{~h}$. Next, they were taken out to set them at FC using $200 \mathrm{ml}$ and $240 \mathrm{ml}$ of deionized water for Soil 1-2 and Soil 3, respectively. Afterwards, the soil samples were lifted to allow the excess water to leak out. In this way, the soil 
samples at FC were obtained. After staying at field capacity for $72 \mathrm{~h}$, the soil samples were placed again in the oven at $40{ }^{\circ} \mathrm{C}$. This exchange between drying and field capacity state was repeated until the end of the experiment.

Twenty $\mathrm{ml}$ of deionized water was added to keep nine soil samples at FC. Later, the soil samples were carefully lifted to enable the leaking of excess water. They were considered at FC when the leaking process had stopped. This procedure was repeated every 72 hours for the entire period that the experiment ran.

At W-FC treatment, nine soil samples went to repeated cycles of waterlogging and field capacity state. First, the soil samples were placed at waterlogging by saturating them with $370 \mathrm{ml}, 310 \mathrm{ml}$ and $410 \mathrm{ml}$ of deionized water for Soil 1, Soil 2 and Soil 3, respectively. They stayed in this condition for $72 \mathrm{~h}$. After 72 hours, the soil samples were carefully lifted to allow the water to leak out until FC was reached. Then, the soil samples remained at FC for $72 \mathrm{~h}$. Next, they were placed again at the waterlogging state. This cycle was repeated for the entire period that the experiment ran.

Drainage was enabled by $5 \mathrm{~mm}$ diameters holes drilled at the bottom of the tray. Likewise, pantyhose filters were used to avoid soil leaking out. The excess water was collected to determine the loss of soluble cations of each soil sample (see section 3.2.5).

Moreover, to eliminate any external influence on soil samples, they were covered with a plastic lid. At D-FC and FC treatments, the soil samples were scanned every $72 \mathrm{~h}$. While for FC treatment, the soil samples were always scanned at field capacity, at D-FC soil samples were scanned either at drying or field capacity state. At W-FC treatment, the soil samples were scanned at field capacity every 144 hours. The images at waterlogging conditions were discarded for further analysis because the water causes dispersion, making the data not comparable to others with no standing water. Twenty-seven soil samples filled with soil with different OM content and the one with added hematite were scanned by the VNIR imaging spectrometer camera, as shown in Figure 3-1. We collected images for eight weeks. The decision of eight weeks experiment was related to the laboratory facilities. 
Monitoring soil surface mineralogy at different moisture conditions using Visible NearInfrared spectroscopy data

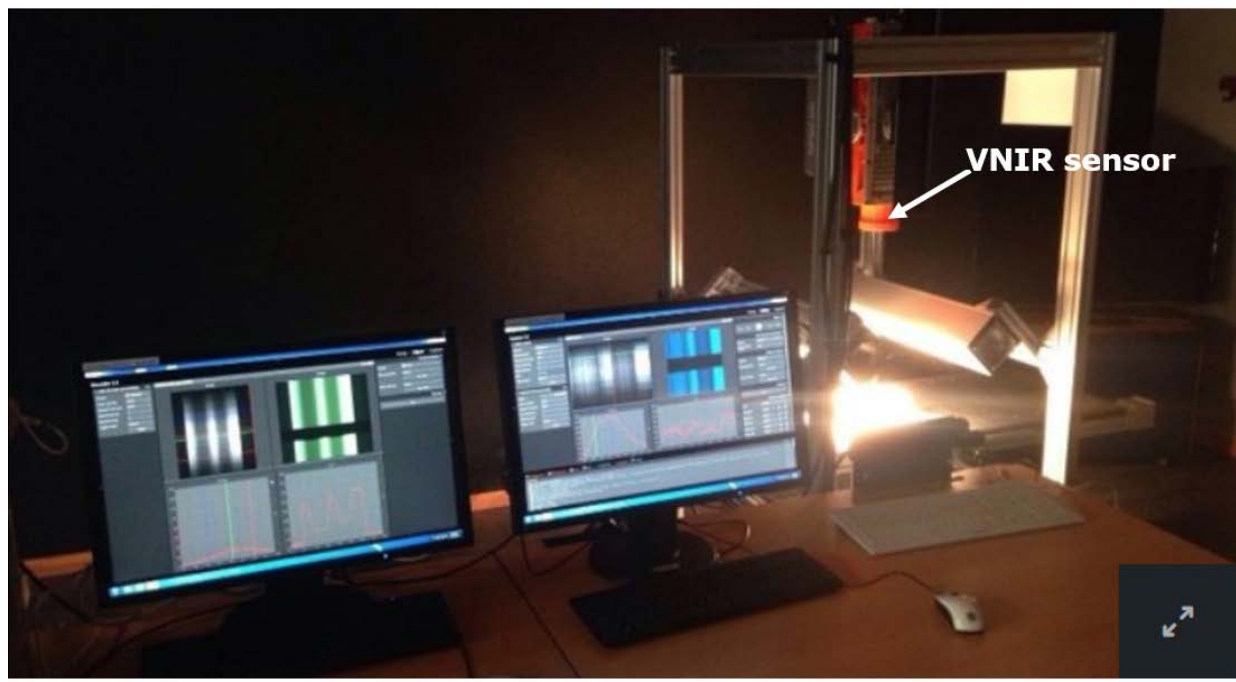

Figure 3-1. The experimental laboratory setup for image data collection. On the tripod in the centre is the VNIR imaging spectrometer camera placed at an angle of $90^{\circ}$. Next to the sensor is a sliding table where the soil tray is placed for scanning. On the right and the left side of the sliding table, an external light source is integrated to illuminate the tray during image acquisition.

\subsubsection{Image Acquisition}

A Specim imaging spectrometer camera was used to investigate mineralogical changes on the soil surface under controlled laboratory conditions. This camera works as a push broom scanner and provides contiguous spectral information for each pixel (Specim). Table 3-2 summarizes the Specim camera characteristics.

Table 3-2. Specim imaging spectrometer camera characteristics of the Visible Near-Infrared sensor.

\begin{tabular}{ll}
\hline Characteristics & Specification \\
\hline Spectral range & $391-1008 \mathrm{~nm}$ \\
Spectral resolution FWHM & $0.75-0.82 \mathrm{~nm}$ \\
Spatial pixels & 1024 \\
Spectral bands & 784 \\
Detector & CMOS (Complementary metal-oxide- \\
& semiconductor sensors) \\
Radiometric resolution & 12 bit \\
Frame rate & $10 \mathrm{fps}$ \\
Spectral binning & 1.2 \\
Output data format & Binary BIL data with separate ASCII \\
& format header, Envi compatible \\
Instrument calibration & Sectral calibration. Normalization \\
& using internal referencing \\
\hline
\end{tabular}


The images were selected, avoiding the shadow and the edge, as shown in Figure 3-2. The image of $204 \times 177$ pixels of VNIR corresponds to an $84 \times 73$ $\mathrm{mm}^{2}$ area with a spatial resolution of $2.4 \mathrm{~mm} /$ pixels.

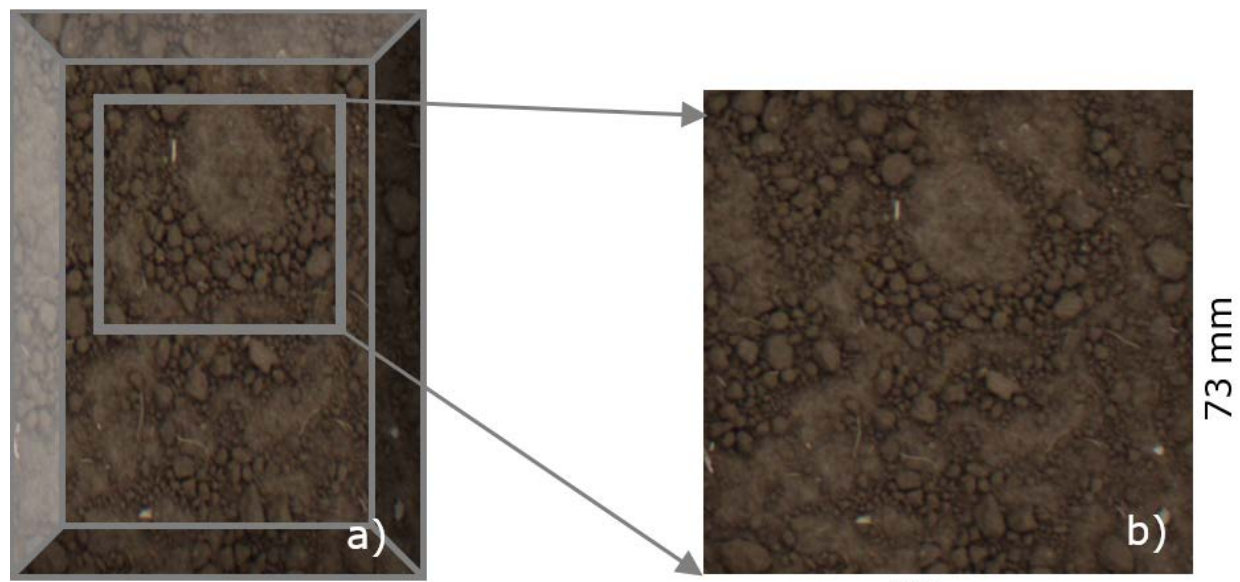

$84 \mathrm{~mm}$

Figure 3-2. Example of an image selected for analysis. In order to avoid shadow, the VNIR image was selected from the upper (a) part of the tray. The image subset of $84 \times 73 \mathrm{~mm}^{2}$ with a pixel size of $2.4 \mathrm{~mm} /$ pixels (b) was obtained.

\subsubsection{I mage processing}

Although spectroscopy data provide useful information for the identification of various materials with similar spectral properties, they suffer from highly correlated and noisy spectral bands (Nguyen and Lee, 2006; Mariotto et al., 2013). Therefore, it is necessary to perform image processing before further data analysis. The noisy bands ranging from $391 \mathrm{~nm}$ to $420 \mathrm{~nm}$ and $951 \mathrm{~nm}$ to $1008 \mathrm{~nm}$ of the VNIR sensor were discarded due to a low signal to noise ratio (Butz et al., 2015). Although the images were spectrally resized, their dimensionality was high ( 676 bands). The processing of the enormous amount of the hyperspectral data might be problematic, leading to high computational cost. To decrease the amount of redundant and correlated spectral bands without losing useful information, spectral binning by averaging every four adjacent bands, i.e., binning was set to four was used (see section 3.2.4). As a result, the spectral dimensionality reduced from 676 to 169 (bands).

Various soil properties affect soil's spectral reflectance, such as soil particle distribution, OM, soil moisture, iron oxide, soil minerals and soil roughness. Therefore, Gaussian stretching, which is similar to histogram equalization, was performed. The idea was to achieve a stretched brightness value distribution, which resembles a normal distribution where tails were clipped to \pm 2 standard deviations. Image-processing tools based on multivariate techniques, such as principal component analysis (PCA), are often applied to reduce the noise. PCA involves a linear decomposition of the original dataset into a new coordinate system based on eigenvectors and principal components (PC) (Richards, 
Monitoring soil surface mineralogy at different moisture conditions using Visible Near$\underline{\text { Infrared spectroscopy data }}$

1993). There can be as many PCs as the number of spectral bands in the original image. However, the first two PCs contain the highest spectral and spatial data variability (J elenek et al., 2016). The rest of the PCs obtain mostly noise (useless information). Implementing forward PC rotation, the first two PCs that contained $99 \%$ of data variability were selected (ENVI, 2015). However, the PC images do not allow identification and quantification of soil mineralogical changes. Therefore, the transformation of the PC images back into their original data space was completed. Figure 3-3 shows the flowchart of the image processing.

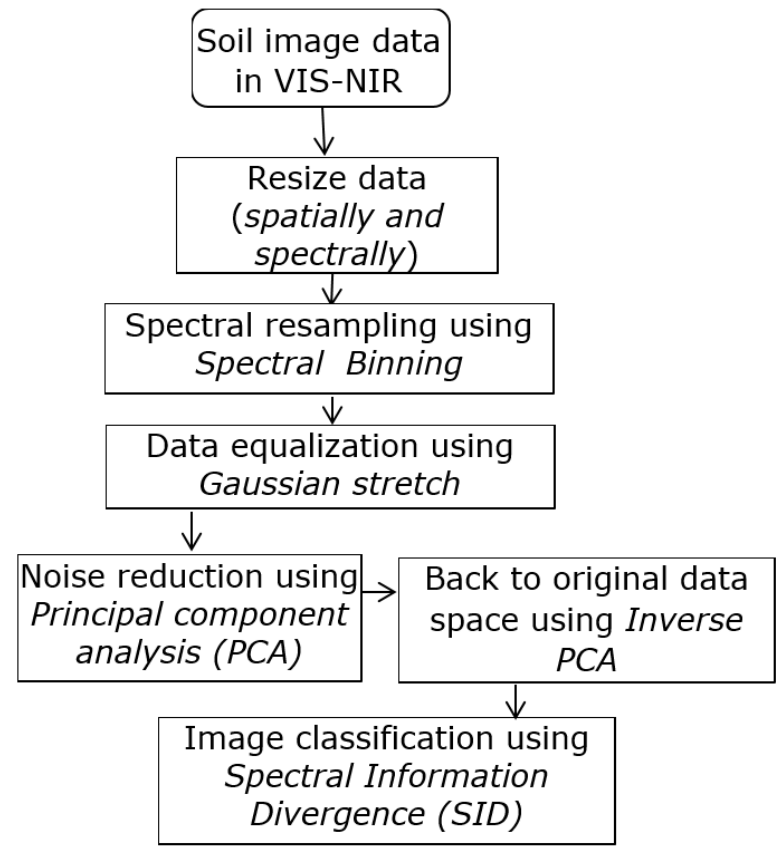

Figure 3-3. Flowchart of the image processing steps followed for each soil image before Spectral Information Divergence image classification was performed.

\subsubsection{Spectral Information Divergence approach (SID)}

The key to imaging spectroscopy classification is the assessment of the spectral similarity of various objects. An image pixel is usually a mixture of different materials with various abundance fractions. Therefore, the high spectral resolution of the sensor (hundreds of spectral bands) does allow resolving these mixtures better than low spectral resolution. Consequently, the spectral information provided by this pixel is essential for material discrimination, detection, identification and classification (Xu et al., 2015; Zhao et al., 2017). The goal was identifying and quantifying the soil mineralogy under D-FC, FC and W-FC treatments. Therefore, the Spectral Information Divergence (SID) spectral similarity approach was used. SID stochastic classifier provides more 
accurate results compared to empirical methods (Qin et al., 2009; van der Meer, 2006). SID uses a divergence measure to match pixels spectra to reference spectra. The more pixels are similar, the smaller the divergence. Pixels are not classified when the divergence measure is greater than the specified maximum divergence threshold. SID measures the spectral variability of a single mixed pixel where each pixel is considered as a random variable and uses its spectral histogram to define a probability distribution (Chang, $2000)$. Considering two spectral vectors, spectral reference $r=\left(r_{1}, r_{2} \ldots r_{N}\right)$ and an unknown spectral image $u=\left(u_{1}, u_{2} \ldots u_{N}\right)$ the SID is calculated based on relative entropy.

Thus, $\operatorname{SID}(r, u)=D(r \| u)+D(u \| r)$

where $\mathrm{D}(\mathrm{r} \| \mathrm{u})=-\sum_{i=1}^{N} p i \log \left(\frac{p i}{q i}\right), \mathrm{D}(\mathrm{u} \| \mathrm{r})=-\sum_{i=1}^{N} q i \log \left(\frac{q i}{p i}\right)$

and pi $=\mathrm{ri} / \sum_{i=1}^{N} r i, \mathrm{qi}=\mathrm{ui} / \sum_{i=1}^{N} u i$

$\mathrm{N}$ is the number of bands; the symbol \| represents both the relative entropy of $u$ with respect to $r$ and the relative entropy of $r$ with respect to $u$.

The spectral reference for the SID classifier was selected from the USGS digital spectral library (USGS, 2017) based on X-ray diffraction analysis of the soil samples, more precisely on the clay fraction of these soils. The clay fraction was determined with the pipette method. X-ray analysis identified a range of minerals such as goethite, hematite, maghemite, Mg-clinochlore, ferroan clinochlore, kaolinite and muscovite. Likewise, the Analytical Spectral Device (ASD Boulder, USA) spectroradiometer acquiring data in the $350 \mathrm{~nm}$ to 2500 $\mathrm{nm}$ spectral range with a spectral interval of $1.4 \mathrm{~nm}$ in VNIR (350-1000 282 $\mathrm{nm}$ ) was used for spectral measurements of Soil 2 . These measurements were performed under a controlled dark condition, using a 512-channel silicon photodiode array. After the white reference optimization, an average spectrum of Soil 2 was obtained. Besides the input spectral information, the SID approach requires a maximum divergence threshold. The image of Soil 1 acquired at the beginning of the experiment was used to determine this threshold (see Table 3-1). This soil image was chosen because its area covered by hematite was known. By trial and error, the maximum divergence threshold value of 0.15 identified the hematite over the image, as shown in Figure 3-4. It was assumed that this threshold $(0.15)$ could identify the other minerals existing in any soil image. Therefore, the SID classification was performed on all the soil samples using this threshold. Together with the threshold trials, various spectral binning for spectral resampling were used when performing the SID classification.

Since each SID class had isolated unclassified pixels, a majority postclassification image analysis using a window $3 \times 3$ pixels was carried out. Next, the percentage of each mineral in each image was calculated based on the pixel count in the image. Here, the number of 36108 pixels corresponded to $100 \%$ of the image in VNIR. Therefore, based on the number of pixels that each mineral occupied in the image, its percentage could be determined. It is essential to point out that the percentage of these minerals was derived from surface measurements, and the soil depth was not considered. 
Monitoring soil surface mineralogy at different moisture conditions using Visible Near$\underline{\text { Infrared spectroscopy data }}$

Both ASD and USGS spectral information were used independently as input to the SID classifier to detect the hematite in Soil 1 (Figure 3-4). The percentage of hematite over the soil image was $36 \%$ and $37 \%$ for ASD and USGS spectral data, respectively. Since this difference was 1\%, the USGS spectral library data could be used instead of measured data to monitor soil mineralogical changes in VNIR.
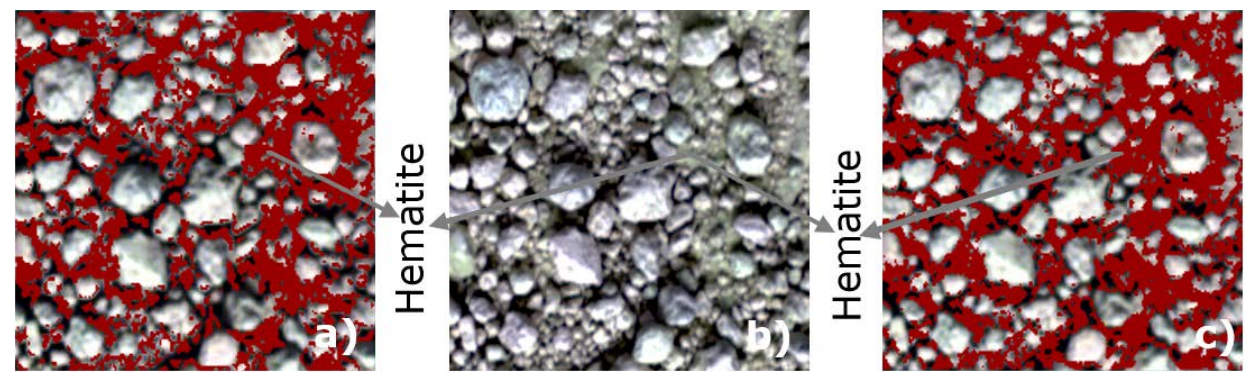

Figure 3-4. The original image (b) of Soil 1 at the beginning of the experiment is in the middle. Using Spectral Information Divergence (SID) classifier with a threshold value of 0.15 , hematite (cherry colour) occurrence over the image was defined. The image classification results, on the left (a) and the right side (c), were obtained using ASD and USGS spectral data, respectively. The black arrows indicate the hematite in the original image and its classification results for both ASD and USGS spectral data used.

\subsubsection{Inductivity Coupled Plasma-Optical Emission Spectrometry Instruments (ICP-OES) measurements}

ICP-OES technique measures the concentration of chemical elements in a solution applying a linear approach (element concentration vs light intensity) (PerkinElmer, 2018). The excess water was collected of each soil sample in tubes of $15 \mathrm{ml}$ to investigate the losses of soluble elements. Likewise, the samples were acidified with nitric acid to keep the elements in the solution. While the samples were measured every week in D-FC and W-FC treatments, these measurements performed every three days in FC treatment. Using the ICP-OES technique, the concentration of $\mathrm{Mg}, \mathrm{Al}, \mathrm{Ca}, \mathrm{K}$, and $\mathrm{Na}$ was determined.

\subsection{Results}

Applying the USGS spectral library, the minerals identified in the VNIR using the SID classifier belong to the phyllosilicate group more specifically to chlorite, iron oxide and hydroxide. Mg-clinochlore, goethite with average grain size 125 $\mu \mathrm{m}$, quartz coated $50 \%$ by goethite (Qz-Gt) and averaged hematite dimorphous with maghemite ( $\mathrm{Hm}-\mathrm{Mh}$ ) with varies grain size interval (150-250, 60-104, 30-45, 10-20 $\mu \mathrm{m}$ ) were used to investigate mineral variation over time. Furthermore, the ferroan clinochlore observed at the dry condition was 
not considered for further analyses. The image processing and analyses were carried out for each soil sample determining the percentage of minerals. Next, we summarized the mineral percentages by averaging triplicates of each soil type (Soil 1- Soil 3) placed in each soil treatment (D-FC, FC and W-FC). Figure 3-5 shows the results at D-FC soil treatment at the start (week0), middle (week4), and the end of the experiment (week8) in the dry condition. One of the soil properties that affect soil's spectral reflectance is indeed the OM. However, it is essential to specify the species of OM occurring in the soil because their composition determines the spectral region that they are active. The OM of Soil 3 comes from sewage sludge manure. The main components in sewage sludge are lignin and cellulose, which have absorption features in the SWIR. Therefore, in VNIR, the sewage sludge manure does not affect the spectral reflectance of the minerals. All the soils showed changes in their minerals distribution over time.
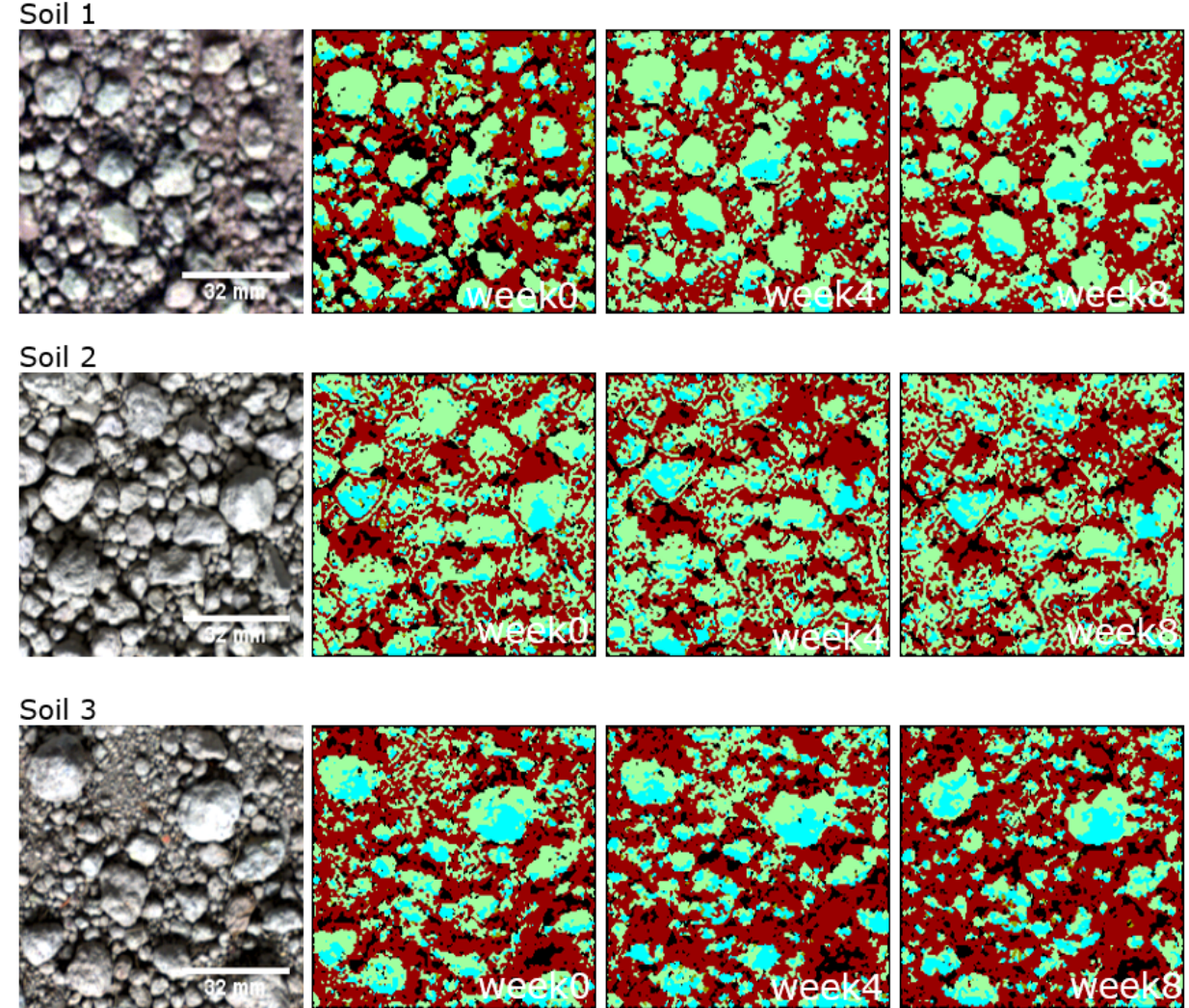

Legend: Mg-clinochlore, Ferroan clinochlore 104-150 $\mu \mathrm{m}$, $\square$ Hematite dimorphous with maghemite ( $\mathrm{Hm}-\mathrm{Mh})$, 口unclassified

Figure 3-5. Example of SID classification results at D-FC treatment at the start (week0), middle (week4) and the end of the experiment (week8) in dry condition (Soil 1- Soil 3). The colours represent the minerals identified in VNIR. All the soils show changes in their mineral distribution over time. The original images at the start of the experiment, together with the scale bar, are also shown. 
Monitoring soil surface mineralogy at different moisture conditions using Visible Near$\underline{\text { Infrared spectroscopy data }}$

\subsubsection{Drying-field capacity treatment (D-FC)}

Mg-clinochlore could be considered stable over time regardless of the soil conditions (wet or dry) or the presence of OM (Figure 3-6a). However, in wet conditions, the percentage of Mg-clinochlore of Soil 2 and Soil 3 was significantly higher compared to Soil 1.

Goethite $125 \mu \mathrm{m}$ was not detected for Soil 3 (high OM) at D-FC soil treatment (Figure 3-6b). In wet conditions, the percentage of goethite of Soil 1 was significantly higher compared to Soil 2. Although the percentage of goethite fluctuated with a small magnitude over time, it tended to increase and decrease for Soil 1 and Soil 2, respectively, at the end of the experiment.

Qz-Gt of Soil 1 was observed only in the wet condition after the first week, and its percentage increased in the second half of the experiment (Figure 3-6c). Likewise, at the wet state, the Qz-Gt of Soil 2 and Soil 3 increased with two percent at the end compared to the start of the experiment.

The $\mathrm{Hm}-\mathrm{Mh}$ was stable at the wet condition for all the soils. While at dry condition, the $\mathrm{Hm}-\mathrm{Mh}$ of Soil 1 increased significantly after week six, this mineral fluctuated over time for Soil 2 and Soil 3 (Figure 3-6d). The magnitude of these fluctuations was higher for Soil 2 compared to Soil 3.
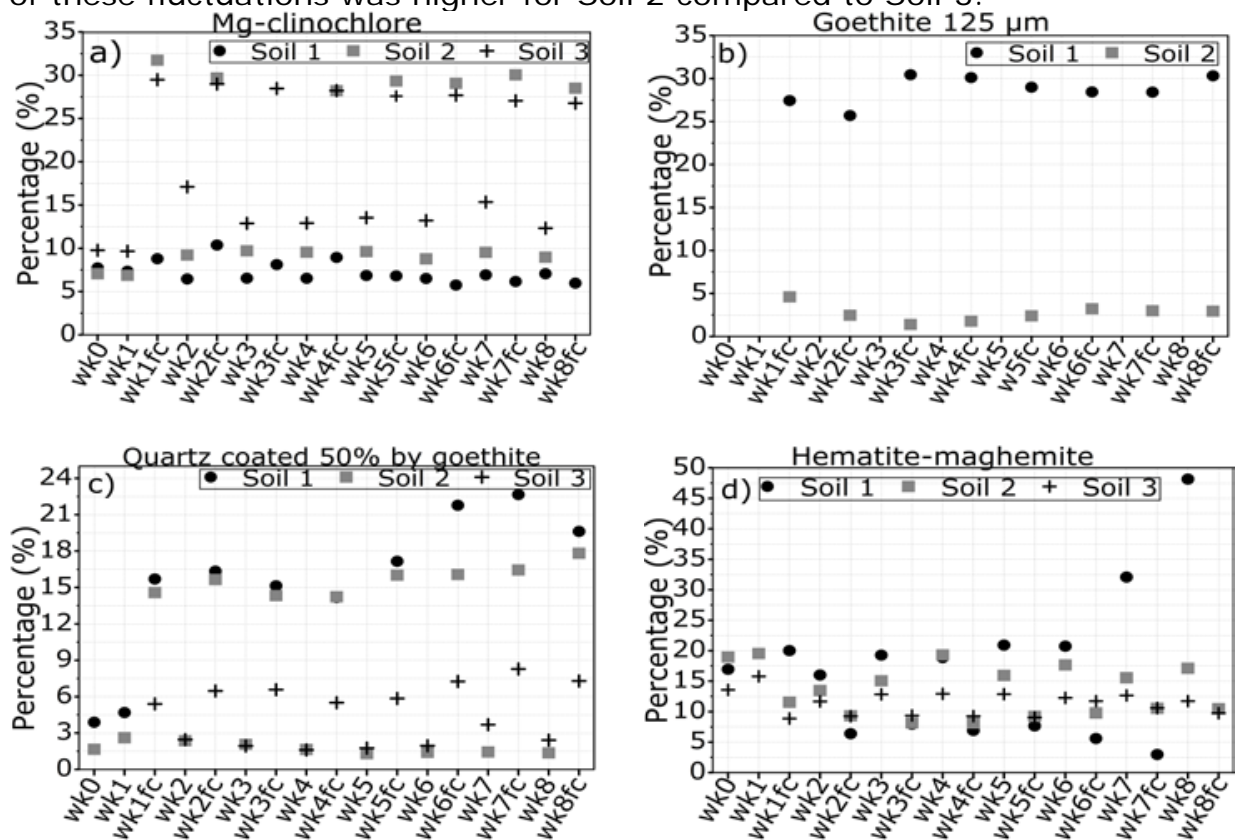

Figure 3-6. The average percentage of Mg-clinochlore (a), goethite $125 \mu \mathrm{m}$ (b), quartz coated $50 \%$ by goethite (c) and hematite dimorphous with maghemite (d) changes for all the soils at the D-FC treatment. The circle, square and plus symbols represent Soil 1, Soil 2, and Soil 3, respectively. The vertical axis characterizes the percentage of each mineral occurring in an image. The scale of the $Y$ axis varies from $0 \%$ to $100 \%$. In the horizontal axis, wk $1, \ldots$, wk8 stands for week $1, \ldots$, week 8 , when the soil sample was at the dry conditions. Since the soil samples were at the field capacity every three days, wk $1 \mathrm{fc}, \ldots$, wk8fc (week $1 \mathrm{fc}, \ldots$, week $8 \mathrm{fc}$ ) was used to represent it. 


\subsubsection{Field capacity treatment (FC)}

Mg-clinochlore of Soil 1 increased until week four, and after week six, it settled for the rest of the experiment (Figure 3-7a). On the other hand, the Mgclinochlore of Soil 2 and Soil 3 decreased continuously after week two until the end of the experiment.

The goethite of Soil 1 decreased for the first half of the experiment. Although this mineral fluctuated in the second half, its percentage was lower compared to the start of the experiment. The goethite of Soil 2 and Soil 3 increased in the second half of the experiment. However, the goethite of Soil 3 settled in the last two weeks of the experiment (Figure 3-7b).

The Qz-Gt of Soil 1 was stable for the entire time that the experiment ran. For Soil 2 and Soil 3, this mineral increased after week three (Figure 3-7c). While the Qz-Gt of Soil 2 stabilized after week six, this mineral settled in the last week of the experiment for Soil 3.

The first FC treatment led to the $\mathrm{Hm}$-Mh decrease for all the soils (Figure 37d). However, this decrease in $\mathrm{Hm}-\mathrm{Mh}$ percentage was higher for Soil 2 compared to Soil 1 and Soil 3. After the first week, the Hm-Mh of Soil 3 and Soil 1 (except some variations) were stable for the rest of the experiment. Although the $\mathrm{Hm}-\mathrm{Mh}$ of Soil 2 fluctuated over time, its percentage was similar in the first week and the end of the experiment.
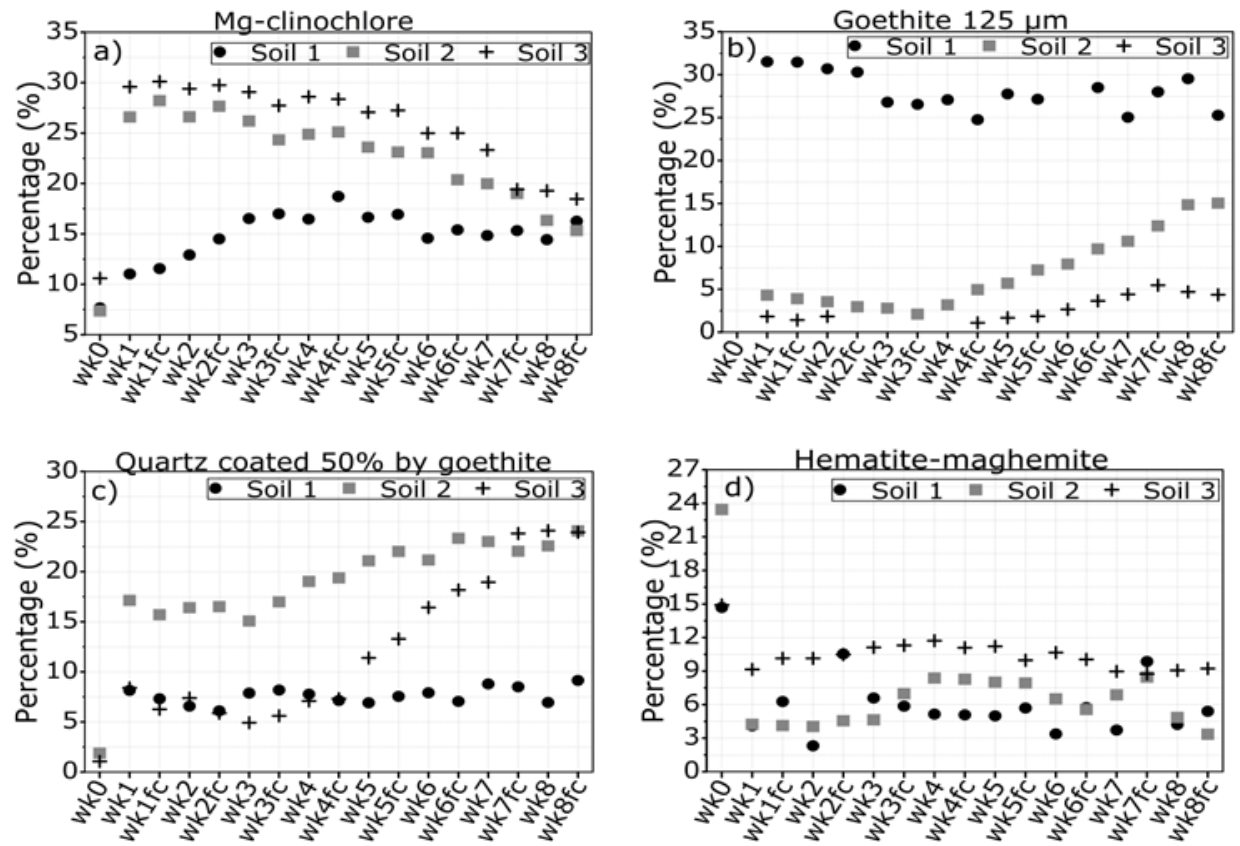

Figure 3-7. The average percentage of Mg-clinochlore (a), goethite $125 \mu \mathrm{m}$ (b), quartz coated $50 \%$ by goethite (c) and hematite dimorphous with maghemite $(d)$ changes for all the soils at the FC treatment. The circle, square and plus symbols represent Soil 1, Soil 2 and Soil 3, respectively. The vertical 
Monitoring soil surface mineralogy at different moisture conditions using Visible Near$\underline{\text { Infrared spectroscopy data }}$

axis characterizes the percentage of each mineral occurring in an image. The scale of the $Y$-axis varies from $0 \%$ to $100 \%$. In the horizontal axis, wk $1, \ldots$. wk8 stands for week $1, \ldots$, week 8 . Since the experiment was performed every three days, wk1fc,..., wk8fc (week $1 \mathrm{fc}, \ldots$, week $8 \mathrm{fc}$ ) was also used to represent the results. Here, the soil samples were at the field capacity all the time.

\subsubsection{Waterlogging-field capacity treatment (W-FC)}

Mg-clinochlore increased for all the soils after the first W-FC treatment (Figure 3-8a). Moreover, the Mg-clinochlore of Soil 1 increased until week three. After that, this mineral stabilized for Soil 1 for the rest of the experiment. On the other hand, Mg-clinochlore of Soil 2 and Soil 3 decreased continuously after week five until the end of the experiment. However, this decrease was more noticeable for Soil 2 compared to Soil 3.

The goethite $125 \mu \mathrm{m}$ of Soil 1 increased continuously until the end of the experiment. After the decrease of the first week, the goethite of Soil 2 stayed stable for the rest of the experiment. This stability was also observed for the goethite of Soil 3 (Figure 3-8b).

The Qz-Gt of Soil 1 decreased continuously for the entire period that the experiment ran. Although with the small magnitude, the Qz-Gt of Soil 2 tended to increase over time. Differently, the Qz-Gt of Soil 3 stayed more or less stable for the entire period of the experiment (Figure 3-8c).

Figure 3-8d shows that the $\mathrm{Hm}$-Mh dropped considerably after the first waterlogging treatment for all the soils. However, this decrease of $\mathrm{Hm}-\mathrm{Mh}$ was more notable for Soil 1 compared to Soil 2 and Soil 3. Later, the Hm-Mh remained stable for the rest of the experiment for all the soils.
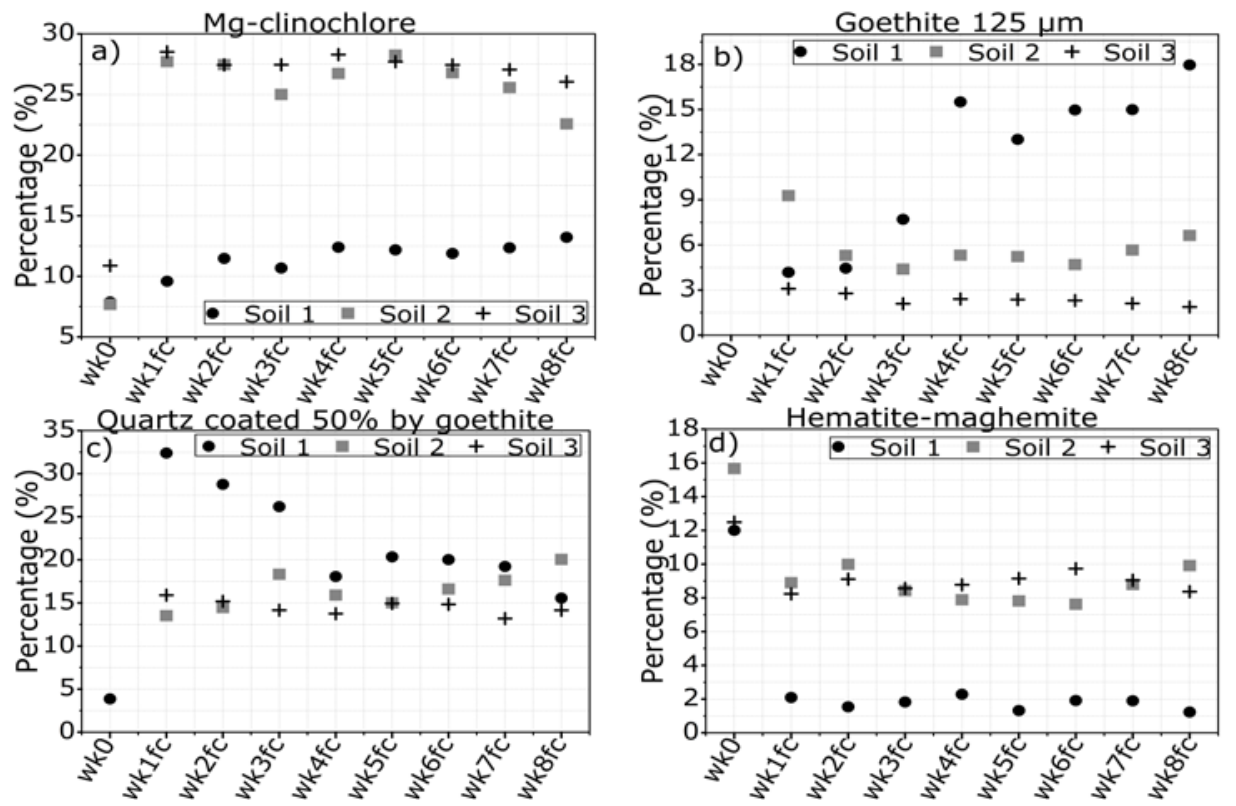
Figure 3-8. The average percentage of Mg-clinochlore (a), goethite $125 \mu \mathrm{m}$ (b), quartz coated $50 \%$ by goethite (c) and hematite dimorphous with maghemite (d) changes for all the soils at the W-FC treatment. The circle, square and plus symbols represent Soil 1, Soil 2, and Soil 3, respectively. The vertical axis characterizes the percentage of each mineral occurring in an image. The scale of the $\mathrm{Y}$-axis varies from $0 \%$ to $100 \%$. In the horizontal axis, wk $1 \mathrm{fc}, \ldots$, wk8fc stands for week $1 \mathrm{fc}, \ldots$, week $8 \mathrm{fc}$ when the soil samples were at the field capacity conditions. There was no data available at the waterlogging conditions.

Figure 3-9 summarized the percentage of the minerals at the start and the end of the experiment when the soil samples were at field capacity. An exception was $\mathrm{Hm}-\mathrm{Mh}$ at $\mathrm{D}-\mathrm{FC}$ treatment, where the soil samples were at the dry condition.

At D-FC treatment, Mg-clinochlore and Qz-Gt decreased and increased for all the soils at the end of the experiment, respectively. An increase of goethite and $\mathrm{Hm}-\mathrm{Mh}$ of Soil 1 occurred at the end of the experiment. On contrarily, these minerals (goethite and $\mathrm{Hm}-\mathrm{Mh}$ ) decreased for Soil 2 and Soil 3 at the end of the experiment at D-FC treatment, as is shown in Figure 3-9a.

At FC treatment, Mg-clinochlore increased and decreased for Soil 1 and Soil 2, Soil 3 at the end of the experiment, respectively. Oppositely, the goethite decreased and increased for Soil 1 and Soil 2, Soil 3 at the end of the experiment, respectively. An increase of Qz-Gt for all the soils occurred at the end of the experiment. The $\mathrm{Hm}-\mathrm{Mh}$ increased, decreased and stayed stable for Soil 1, Soil 2 and Soil 3 at the end of the experiment (Figure 3-9b).

At W-FC treatment, Mg-clinochlore and goethite declined at the end of the experiment for Soil 2 and Soil 3 (Figure 3-9c). On the contrary, these minerals (Mg-clinochlore and goethite) increased for Soil 1 at the end of the experiment. The other mineral, Qz-Gt, decreased for Soil 1 and Soil 3 and increased for Soil 2 at the end of the experiment. $\mathrm{Hm}-\mathrm{Mh}$ of Soil 1 and Soil 3 stayed stable, whereas it increased for Soil 2 at the end of the experiment.
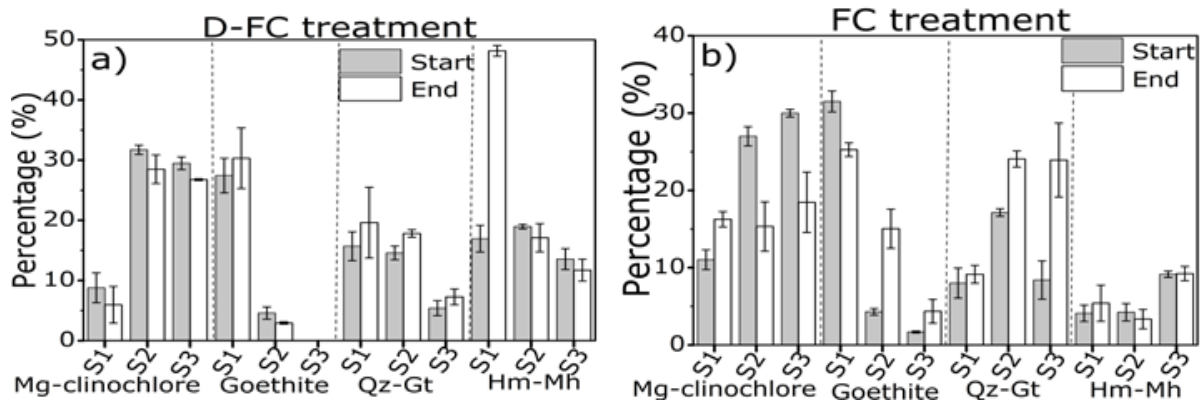
Monitoring soil surface mineralogy at different moisture conditions using Visible NearInfrared spectroscopy data

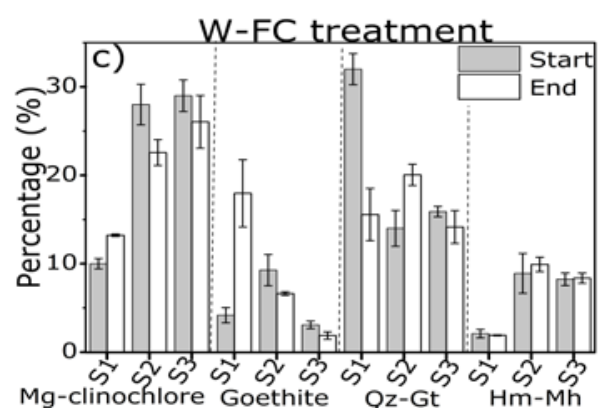

Figure 3-9. The percentage of the minerals when the Soil samples were at the field capacity. An exception was the $\mathrm{Hm}$ - Mh at the D-FC treatment, where the Soil samples were at the dry conditions. The vertical axis characterizes the percentage of each mineral occurring in an image. The horizontal axis represents the Mg-clinochlore, goethite $125 \mu \mathrm{m}$, quartz coated $50 \%$ with goethite (Qz-Gt) and hematite dimorphous with maghemite ( $\mathrm{Hm}-\mathrm{Mh}$ ) of Soil 1-Soil 3 (S1-S3) in the drying-field capacity (a), field capacity (b) and waterlogging- field capacity (c) treatments at the start and end of the experiment. The error bars represent the standard deviation of the minerals in triplicated Soil samples. Since the SID approach disregards the self-shadow areas created by various Soil aggregate sizes, these aggregate variations influenced the standard deviation.

\subsubsection{ICP- OES results}

CEC refers to the ability of negatively charged soil particles to attract and retain cations such as $\mathrm{Ca}^{2+}, \mathrm{Mg}^{2+}, \mathrm{K}^{+}, \mathrm{Na}^{+}, \mathrm{Al}^{3+}$ by electrostatic forces.

At D-FC treatment, the loss of $\mathrm{Ca}, \mathrm{Mg}, \mathrm{K}, \mathrm{Na}, \mathrm{Al}$ of Soil 1 increased at week two (Figure 3-10a). After that, it decreased continuously over time. However, this decrease was higher for $\mathrm{Ca}$, followed by $\mathrm{K}, \mathrm{Mg}, \mathrm{Na}$ and $\mathrm{Al}$. Regardless of the amount of OM, the concentration of cations of Soil 2 and Soil 3 was low and stayed stable over time. Magnesium was not detected for Soil 2 and Soil 3 in D-FC treatment.

At FC treatment, the concentration of all the elements fluctuated over time for Soil 1. However, the loss of $\mathrm{K}, \mathrm{Na}$ and $\mathrm{Al}$ decreased; it increased for $\mathrm{Mg}$ and did not change for $\mathrm{Ca}$ at the end compared to the start of the experiment. Except for $\mathrm{Mg}$, which was not detected, the concentration of other elements of Soil 2 and Soil 3 fluctuated with a small magnitude over time (Figure 3-10b). Figure 3-10c shows that the loss of $\mathrm{Ca}, \mathrm{Mg}, \mathrm{K}$ and $\mathrm{Na}$ of Soil 1 decreased over time at W-FC treatment. While this decrease was fast until week three, it slowed down for the rest of the experiment. The other element, Al, decreased at week two to stay stable until week six to drop again until the end of the investigation. The concentration of $\mathrm{Ca}, \mathrm{Mg}, \mathrm{K}$ and $\mathrm{Na}$ of Soil 2 and Soil 3 did not change over time at W-FC treatment. 

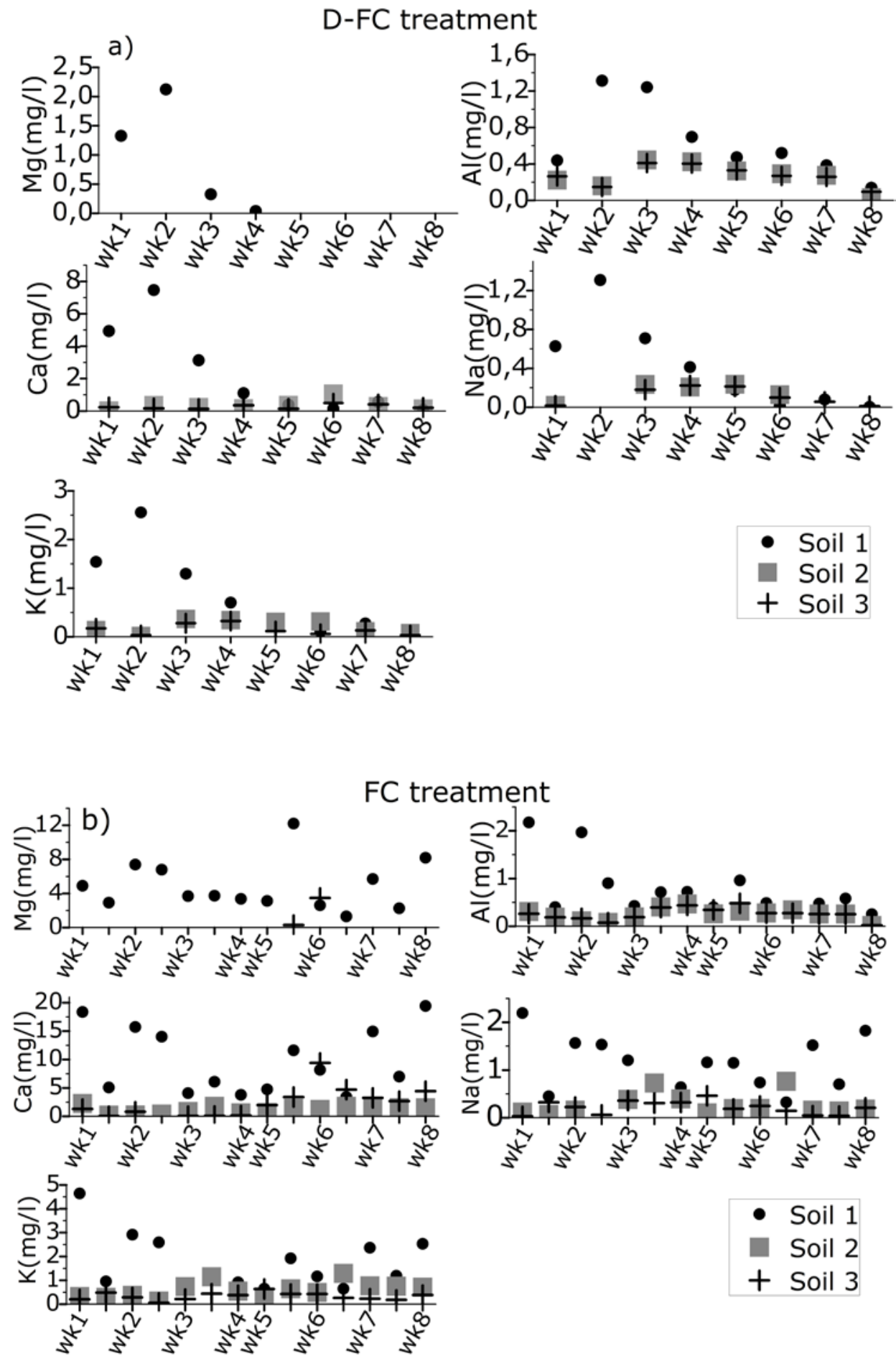
Monitoring soil surface mineralogy at different moisture conditions using Visible Near$\underline{\text { Infrared spectroscopy data }}$

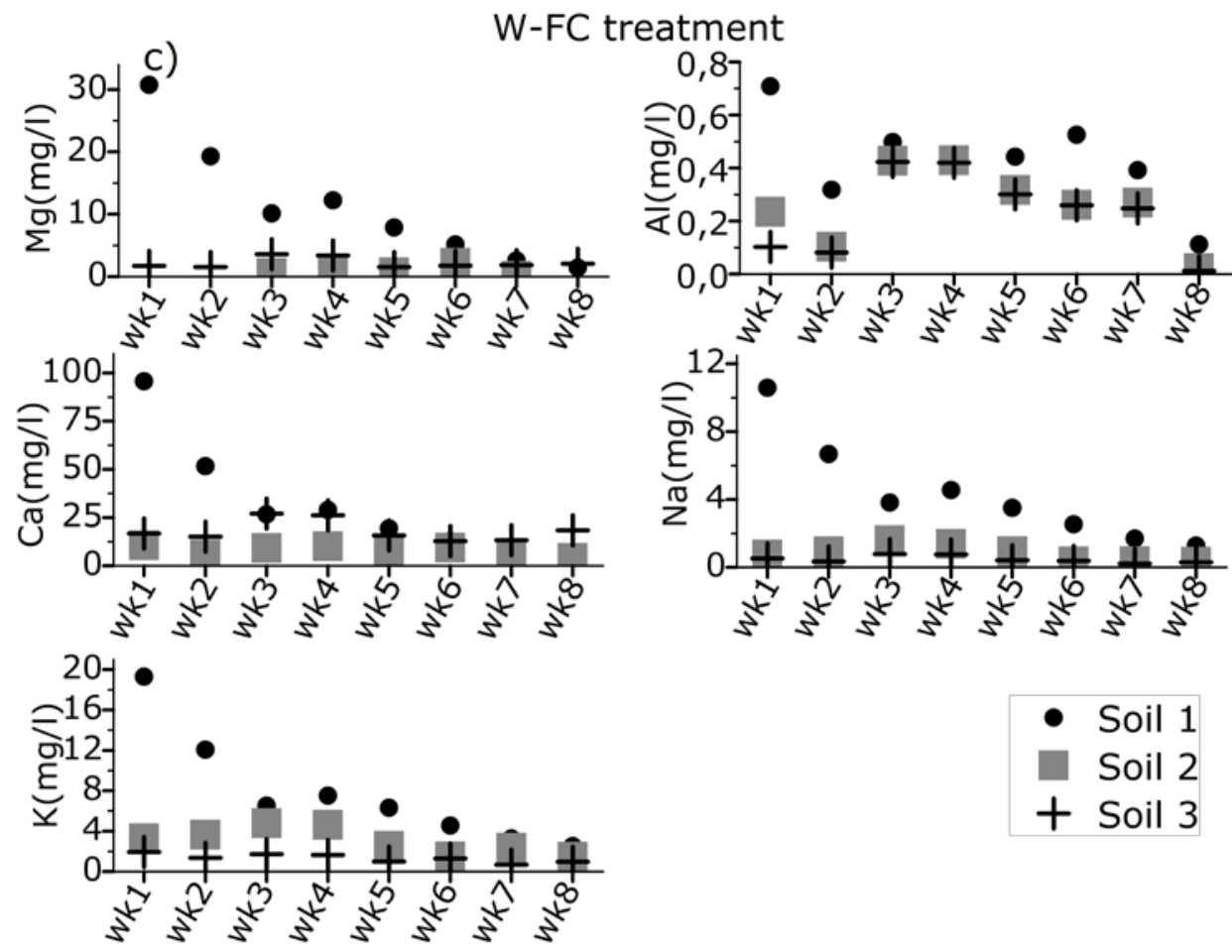

Figure 3-10. The concentration of cations determined using the Inductivity Coupled Plasma-Optical Emission Spectrometry Instruments (ICP-OES) technique at the drying- field capacity (a), field capacity (b), and waterloggingfield capacity (c) treatments for Soil 1-Soil 3. While the results were every week for the D-FC and the W-FC treatments, the results were at three days basis for the FC treatment.

\subsection{Discussion}

\subsubsection{Drying-field capacity treatment (D-FC)}

Repeated drying and field capacity cycles can cause changes in soil chemical composition due to the migration of soil chemical elements such as $\mathrm{Ca}, \mathrm{Fe}, \mathrm{Mg}$, Al, K, Na or Si (Bravo-Garza et al., 2009; Pires et al., 2011). Moreover, the ICP-OES results indicated that the loss of soluble elements was noticeable for Soil 1. On the contrary, the presence of OM (Soil 2 and Soil 3) diminishes the loss of cations from the soil matrix. The image analysis showed that Mgclinochlore of Soil 1 stayed stable over time regardless of the soil conditions (dry or field capacity). The Mg-clinochlore of Soil 2 and 3 fluctuated with a small magnitude, considering this mineral relatively stable. This stability of Mgclinochlore at D-FC treatment could be related to the increase of the cohesion 
between organic molecules and mineral surfaces in dry conditions (Denef et al., 2002).

The goethite is active at the wet condition, whereas the hematite prevails in the dry soil condition. Indeed, the SID classifier detected the goethite only at field capacity condition. This mineral was stable over time. Goethite adheres to quartz surfaces by covalent Fe-Si-O bonds (Scheidegger et al., 1993) occurring as quartz coated $50 \%$ by goethite in this experiment. The presence of OM makes goethite negatively charged, allowing it to precipitate over time. Moreover, the fulvic and humic acids increase the weathering of quartz, especially when the soil is at neutral pH (Welch and Ullman, 1993; Wogelius and Walther, 1991). However, the results showed that Qz-Gt stayed stable over time for soils with OM. These results could be explained with the presence of $\mathrm{Al}$ and Fe oxides stabilizing the soil upon drying, as well as the short period (eight weeks) that the experiment ran. Due to the absence of OM, the goethite is positively charged. Therefore, it could be immobilized due to attractive electrostatic interactions with the negatively charged soil matrix minerals, such as quartz (Bosch et al., 2010). However, the results showed an increase in the Qz-Gt of Soil 1 in the second half of the experiment. These results might be related to changes in the Soil 1 mineralogy, such as recrystallization of Fe and Al oxyhydroxides, when exposed to high-temperature (Arcenegui et al., 2008; Guerrero et al., 2001).

Like the other minerals, the $\mathrm{Hm}$-Mh of soils with OM was relatively stable for the duration of our experiment. Indeed, the Fe oxides have a large specific surface area playing a significant role in forming organo-mineral associations within soils (Cismasu et al., 2016; Regelink et al., 2013). Also, Regelink et al., (2015) showed that the interactions between amorphous iron oxides and OM were significant to soil stability. The $\mathrm{Hm}-\mathrm{Mm}$ of Soil 1 increased at the end of the experiment. This increase could be related to both the hematite and maghemite. The added hematite in Soil 1 did not have enough time to integrate into the soil matrix leading to leaching and attachment of the small grain size to bigger ones. Moreover, the maghemite is poorly crystallized, leading to its mobility and precipitation in porous media (Taylor and Schwertmann, 1974; Tratnyek and Johnson, 2006).

\subsubsection{Field capacity treatment (FC)}

Soil moisture controls mainly the chemical weathering and mineral transformations (Egli et al., 2014). When the soil was at field capacity conditions, the Mg-clinochlore of Soil 2 and 3 (low and high OM) decreased over time. Indeed, the instability of the chlorite minerals in the soil is known (Righi et al., 1993). This instability could be related to the large molecule of magnesium, which does not stick tightly to soil particles. As a result, it could easily leach from the soil at neutral pH (McCauley et al., 2017). Moreover, generally, OM can stabilize the soil by increasing the inter-particle cohesion within soil aggregates (Zaher et al., 2005). However, manure (present in soils) does not increase soil cohesion (Paré et al., 1999). Therefore, the leakage of $\mathrm{Mg}$ and its weak inter-particle cohesion leads to a decrease of $\mathrm{Mg}$-clinochlore. 
Monitoring soil surface mineralogy at different moisture conditions using Visible Near$\underline{\text { Infrared spectroscopy data }}$

Both the goethite and Qz-Gt of Soil 2 and 3 increased at the end of the experiment. The soil at wet conditions is not fully oxic, which may lead to reducing conditions. Under such conditions, the accumulation of crystalline Fe hydroxide phases such as goethite might occur (Hansel et al., 2003; Pedersen et al., 2005).

The associations of goethite with OM is weak because the coverage of goethite by OM prevents the action of attractive forces, and therefore, increasing the electrostatic repulsive forces between colloids (Dultz et al., 2018). The precipitation of goethite and the weathering of quartz simulated by fulvic and humic acids could lead to the accumulation of Qz-Gt over time.

Regardless of soil type, the $\mathrm{Hm}-\mathrm{Mh}$ was relatively stable over time. Both crystalline or amorphous Fe species (hematite or maghemite) might interact with soil inorganic and organic components due to van der Waals attraction (Colombo and Torrent, 1991). These results could be related to the hematite suppression at the field capacity conditions.

Mg-clinochlore, goethite and Qz-Gt of Soil 1 were stable. One explanation is that Soil 1 went through the high temperature, declining the exchangeable cations, and making this soil in an unchanging condition (Sunil and Deepa, 2016).

In the soil environment, where oxygen is sufficient, the attachment of aerobic microorganisms on the mineral surface is a known process (J ones and Bennett, 2014). As a result, the attached microorganisms dissolve the minerals based on their nutritional needs causing mineral dissolution and element mobilization such as Fe, Mg, Al and Si (Ahmed and Holmstrom, 2015). Therefore, the changes in the percentage of minerals in the FC state could be related to the mineral weathering by the microorganisms.

\subsubsection{Waterlogging-field capacity treatment (W-FC)}

The experiment showed that the first waterlogging-field capacity treatment had a significant effect on soil mineralogy, regardless of soil type. However, for the rest of the experiment, the minerals were stable, especially for the soils with OM.

Mg-clinochlore was stable over time. The minerals dissolved in waterlogged soils, and consequently, elements such as $\mathrm{Mg}$ can be released into the solution at low redox potential (waterlogging state) (Lesovaya et al., 2012; Raous et al., 2010). The ISP-OES results also showed the loss of $\mathrm{Ca}, \mathrm{Mg}, \mathrm{K}$ and $\mathrm{Na}$ of Soil 1. However, the image analysis suggested that $\mathrm{Mg}$-clinochlore of Soil 1 stayed stable. These results indicate the importance of considering the changes in the minerals together with other soil components and not per se because they depend on the interactions with the other soil components.

OM interactions with the soil minerals by cationic bridges are considered weak. Moreover, the OM adsorbed on mineral surfaces does not cover the whole particle surface, but it forms patches (Remusat et al., 2012; Rumpel et al., 2015). Even the newly adsorbed OM binds to existing patches and not to free mineral surfaces (Vogel et al., 2014). Therefore, the Mg and OM might not be capable of creating new bridges under W-FC treatment, causing the stability of Mg-clinochlore for Soil 2 and Soil 3. 
Although the goethite can precipitate from solution at normal environmental $\mathrm{pH}$, the presence of Al prevents this process (Bazilevskaya et al., 2012). Likewise, it was proved by Thompson et al., (2006) that nanocrystalline goethite transformed into microcrystalline hematite and goethite as a result of soil redox fluctuations. Soil anaerobic conditions could cause the dissolution of maghemite (Grimley and Arruda, 2007; Thompson et al., 2011). Also, Al destroys vacancy ordering in maghemite (Wolska and Schwertmann, 1989). However, in the waterlogging condition, the nanoparticles could remain in the suspension, or they might aggregate and precipitate from the solution. During aggregation, dissolved ions stay within aggregates due to the inter-particle pore space leading to aggregate settling. Moreover, at neutral $\mathrm{pH}$, the unstable particles dissolve and re-precipitate on the surface of other growing particles (Tamrat et al., 2018). Therefore, the stability of goethite, Qz-Gt and Hm-Mh could be related to the re-precipitation process. Moreover, in oxic conditions, the Fe precipitates as goethite and hematite from silicate minerals. Because of the $\mathrm{Si}$ and $\mathrm{Al}$ or $\mathrm{OM}$, the $\mathrm{Fe}^{3+}$ and $\mathrm{Fe}^{2+}$ oxyhydroxides have a low, reducing ability over time (Hansel et al., 2011; Pasakarnis et al., 2015).

The increase of goethite and the decrease Qz-Gt of Soil 1 could be related to added hematite manually. The high clay content increases soil cohesion and decreases permeability for the dissolved and colloidal compounds making the leaching process less pronounced. Therefore, high clay content has a positive influence on soil stability. Soil 3 with $23 \%$ kaolinite showed fewer variations over time than Soil 2, which had $16 \%$ kaolinite at W-FC treatment. Of course, clay content and clay mineralogy have a significant effect on soil organominerals interactions. Therefore, in soils dominated by $1: 1$ clay, the aggregation occurs due to the binding capacity of the minerals themselves. Instead, clay forms bridges with polyvalent metal and OM in soils with a 2:1 layer structure (Six et al., 2000). The effect of kaolinite was not investigated because this clay mineral is detected in the SWIR region of the electromagnetic spectrum.

The SID classifier is a probabilistic approach that uses the divergence measure to compare each pixel spectra with the reference spectra. If this divergence, which is related to a threshold, is small, then the pixel spectra are close to reference spectra. Hence, the pixels that have the divergence greater than the specified threshold are not classified. The threshold value used in this study was 0,15, but it could vary for different mineral types. A threshold that discriminates well for one mineral might be either too sensitive or not sensitive enough for another mineral due to the similar/dissimilar nature of their probability distributions. Besides unclassified pixels, misclassification due to a false positive or false negative errors could occur as well. Therefore, the threshold used in the SID classifier should be specific for each mineral. At the start of the experiment, in D-FC treatment, the percentage of unclassified pixels was $14 \%, 13 \%$ and $14 \%$ for Soil 1 , Soil 2 and Soil 3 , respectively. When the soil was in wet condition, the percentage of unclassified pixels was $29 \%$, $25 \%$ and $24 \%$ for Soil 1, Soil 2 and Soil 3, respectively.

One explanation might be related to minerals behaviour such as the ferroan clinochlore, which was observed only in dry conditions (data not shown). Likewise, hematite prevails in the dry condition, and the goethite overcomes in the wet soil condition. Furthermore, soil aggregates lead to self-shadowing of the soil surface resulting in a low reflectance value. The SID classifier characterizes each mineral type by using its corresponding spectral signature, 
Monitoring soil surface mineralogy at different moisture conditions using Visible NearInfrared spectroscopy data

neglecting the spectral information associated with the shadow. Since the shadow area depends on the soil aggregates size and their occurrence in the image, the percentage of unclassified pixels varies for each soil sample. However, Chang, (2000) pointed out that the SID classier is insensitive to illumination effects and brightness shifts. Although the dimensionality of the images was reduced based on added hematite (section 3.2.4), a large number of available spectral bands (169) and the small training samples (8) could have affected the classification accuracy referred to as the Hughes phenomenon (Hughes, 1968).

One of the main drawbacks of the RS classification approach is the validation of the results with ground truth data. Unfortunately, the ground truth information is not available all of the time. In this study, the spectral data from the ASD device together with USGS spectral library data were used to define and quantify the percentage of added hematite manually distribution over the soil image. Since the difference between the ASD and USGS was 1\%, the USGS spectral library data could be used instead of measured data. The occurrence of other minerals in the soil was unknown; therefore, it was assumed that the USGS spectral library could be used to capture the distribution of these minerals occurring in the soil.

Soil organo-mineral associations occur over a range of bonding mechanisms such as cation and anion exchange, water and cation bridging, ligand, hydrogen and van der Waals and hydrophobic interaction (Qafoku, 2015). While some of these organo-mineral bonds are assumed to be susceptible to disruption, others are considered stable, therefore, affecting soil stability in different ways. Hence, it is crucial to know their behaviour at the high spatial and temporal resolution as well at the vertical soil horizons. RS can play a significant role in acquiring relevant data. However, at this stage, it is difficult to capture in detail the soil organic-mineral interactions, which occur at the nanoscale, to field-scale observations. Likewise, the soil organo-mineral bonds at the subsurface level with RS needs attention. At this point, potential users can be the scientific community dealing with soil stability and environmental concern.

\subsection{Conclusions}

In this study, the SID image classifier derived from the VNIR spectroscopy data was used to monitor the soil mineralogical alterations under laboratory conditions. Three Silty Loam soils varying in OM content (no, low and high) were chosen. Trays with aggregates were exposed to D-FC, FC and W-FC treatments. These treatments were performed because there is limited knowledge of soil mineralogical behaviour at different moisture conditions occurring in a short period. The ICP-OES measurements were carried out to quantify the losses of soluble elements by percolation for each soil sample.

The assumption was that using the VNIR spectroscopy data changes in soil mineralogy due to moisture variation could be detected and quantified over time. Using the SID approach, the image area occupied by Mg-clinochlore, goethite, quartz coated $50 \%$ by goethite, hematite dimorphous with maghemite was determined. The results showed that these minerals behaved 
differently, depending on the soil type and soil treatment. While for the soils with $\mathrm{OM}$, the mineralogical alterations were evident at field capacity state, for the one with no OM, these changes were insignificant. However, regardless of the soil type, these minerals were stable at D-FC and W-FC treatments. Using imaging spectroscopy data, it is shown that the Silty Loam soil mineralogy changes over time, depending on soil type and moisture conditions. Changes in mineral composition might cause changes in the soil aggregate stability. Therefore, it will be interesting to investigate the effect of these mineralogical changes on soil aggregate stability.

\subsection{References}

Ahmed, E., Holmstrom, S.J.M., 2015. Microbe-mineral interactions: The impact of surface attachment on mineral weathering and element selectivity by microorganisms. Chemical Geology. 403, 13-23.

Arcenegui, V., Guerrero, C., Mataix-Solera, J ., Mataix-Beneyto, J., Zornoza, R., Morales, J., Mayoral, A.M., 2008. The presence of ash as an interference factor in the estimation of the maximum temperature reached in burned soils using near-infrared spectroscopy (NIR). Catena. 74(3), 177-184.

Barto, E. K., Alt, F., Oelmann, Y., Wilcke, W., Rillig, M.C., 2010. Contributions of biotic and abiotic factors to soil aggregation across a land use gradient. Soil Biology and Biochemistry. 42(12), 2316-2324.

Bazilevskaya, E., Archibald, D.D., Martinez, C.E., 2012. Rate constants and mechanisms for the crystallization of Al nano-goethite under environmentally relevant conditions. Geochimica Et Cosmochimica Acta. 88, 167-182.

Bosch, J., Fritzsche, A., Totsche, K.U., Meckenstock, R.U., 2010. Nanosized Ferrihydrite Colloids Facilitate Microbial Iron Reduction under Flow Conditions. Geomicrobiology Journal. 27(2), 123-129.

Bravo-Garza, M.R., Bryan, R.B., Voroney, P., 2009. Influence of wetting and drying cycles and maize residue addition on the formation of water stable aggregates in Vertisols. Geoderma. 151(3), 150-156.

Breuer, J., Schwertmann, U., 1999. Changes to hardsetting properties of soil by addition of metal hydroxides. European J ournal of Soil Science. 50(4), 657664.

Butz, C., Grosjean, M., Fischer, D., Wunderle, S., Tylmann, W., Rein, B., 2015. Hyperspectral imaging spectroscopy: a promising method for the biogeochemical analysis of lake sediments. Journal of Applied Remote Sensing. 9.

Chan, K.Y., Heenan, D.P., 1999. Lime-induced loss of soil organic carbon and effect on aggregate stability. Soil Science Society of America Journal. 63(6), 1841-1844.

Chang, C.I., 2000. An information-theoretic approach to spectral variability, similarity, and discrimination for hyperspectral image analysis. leee Transactions on Information Theory. 46(5), 1927-1932.

Cismasu, A.C., Williams, K.H., Nico, P.S., 2016. Iron and Carbon Dynamics during Aging and Reductive Transformation of Biogenic Ferrihydrite. Environmental Science \& Technology. 50(1), 25-35. 
Monitoring soil surface mineralogy at different moisture conditions using Visible Near$\underline{\text { Infrared spectroscopy data }}$

Colombo, C., Torrent, J., 1991. Relationships between aggregation and ironoxides terra rossa soils from southern Italy. Catena. 18(1), 51-59.

Denef, K., Six, J., Merckx, R., Paustian, K., 2002. Short-term effects of biological and physical forces on aggregate formation in soils with different clay mineralogy. Plant and Soil. 246(2), 185-200.

Duiker, S.W., Rhoton, F.E., Torrent, J., Smeck, N.E., Lal, R., 2003. Iron (hydr)oxide crystallinity effects on soil aggregation. Soil Science Society of America J ournal. 67(2), 606-611.

Dultz, S., Steinke, H., Mikutta, R., Woche, S. K., Guggenberger, G., 2018. Impact of organic matter types on surface charge and aggregation of goethite. Colloids and Surfaces a-Physicochemical and Engineering Aspects. 554, 156168.

Egli, M., Dahms, D., Norton, K., 2014. Soil formation rates on silicate parent material in alpine environments: Different approaches-different results? Geoderma. 213, 320-333.

ENVI., 2015. Exelis Visual Information Solutions. from http://www.harrisgeospatial.com/.

Falsone, G., Celi, L., Stanchi, S., Bonifacio, E., 2016. Relative importance of mineralogy and organic matter characteristics on macroaggregate and colloid dynamics in Mg-silicate dominated soils. Land Degradation \& Development. 27(7), 1700-1708.

Gomez, C., Oltra-Carrió, R., Bacha, S., Lagacherie, P., Briottet, X., 2015. Evaluating the sensitivity of clay content prediction to atmospheric effects and degradation of image spatial resolution using Hyperspectral VNIR/SWIR imagery. Remote Sensing of Environment. 164, 1-15.

Grimley, D.A., Arruda, N.K., 2007. Observations of magnetite dissolution in poorly drained soils. Soil Science. 172(12), 968-982.

Guerrero, C., Mataix-Solera, J., Navarro-Pedreno, J., Garcia-Orenes, F., Gomez, I., 2001. Different patterns of aggregate stability in burned and restored soils. Arid Land Research and Management. 15(2), 163-171.

Hanesch, M., Stanjek, H., Petersen, N., 2006. Thermomagnetic measurements of soil iron minerals: the role of organic carbon. Geophysical Journal International. 165(1), 53-61.

Hansel, C.M., Benner, S.G., Neiss, J., Dohnalkova, A., Kukkadapu, R. K., Fendorf, S., 2003. Secondary mineralization pathways induced by dissimilatory iron reduction of ferrihydrite under advective flow. Geochimica Et Cosmochimica Acta. 67(16), 2977-2992.

Hansel, C.M., Learman, D.R., Lentini, C.J., Ekstrom, E.B., 2011. Effect of adsorbed and substituted $\mathrm{Al}$ on $\mathrm{Fe}(\mathrm{II})$-induced mineralization pathways of ferrihydrite. Geochimica Et Cosmochimica Acta. 75(16), 4653-4666.

Hughes, G.F., 1968. On mean accuracy of statistical pattern recognizers. leee Transactions on Information Theory. 14(1), 55-+.

Jelenek, J., Kopackova, V., Koucka, L., Misurec, J., 2016. Testing a Modified PCA-Based Sharpening Approach for Image Fusion. Remote Sensing. 8(10), 25.

J ones, A.A., Bennett, P.C., 2014. Mineral Microniches Control the Diversity of Subsurface Microbial Populations. Geomicrobiology Journal. 31(3), 246-261.

Kaiser, M., Ellerbrock, R.H., Wulf, M., Dultz, S., Hierath, C., Sommer, M., 2012. The influence of mineral characteristics on organic matter content, composition, and stability of topsoils under long-term arable and forest land use. Journal of Geophysical Research-Biogeosciences. 117. 
Kleber, M., Eusterhues, K., Keiluweit, M., Mikutta, C., Mikutta, R., Nico, P.S., 2015. Mineral-Organic Associations: Formation, Properties, and Relevance in Soil Environments. Advances in Agronomy, Vol 130. D. L. Sparks. San Diego, Elsevier Academic Press Inc. 130, 1-140.

Kogel-Knabner, I., Guggenberger, G., Kleber, M., Kandeler, E., Kalbitz, K., Scheu, S., Eusterhues, K., Leinweber, P., 2008. Organo-mineral associations in temperate soils: Integrating biology, mineralogy, and organic matter chemistry. Journal of Plant Nutrition and Soil Science-Zeitschrift Fur Pflanzenernahrung Und Bodenkunde. 171(1), 61-82.

Lesovaya, S.N., Goryachkin, S. V., Polekhovskii, Y.S., 2012. Soil formation and weathering on ultramafic rocks in the mountainous tundra of the Rai-Iz massif, Polar Urals. Eurasian Soil Science. 45(1), 33-44.

Liu, H.B., Chen, T.H., Zou, X.H., Qing, C.S., Frost, R.L., 2013. Thermal treatment of natural goethite: Thermal transformation and physical properties. Thermochimica Acta. 568, 115-121.

Mariotto, I., Thenkabail, P.S., Huete, A., Slonecker, E.T., Platonov, A., 2013. Hyperspectral versus multispectral crop-productivity modeling and type discrimination for the HysplRI mission. Remote Sensing of Environment. 139(Supplement C), 291-305.

Martins, M.R., Angers, D.A., Corá, J.E., 2013. Non-labile plant C contributes to long-lasting macroaggregation of an Oxisol. Soil Biology and Biochemistry. 58(Supplement C), 153-158.

McCauley, A., Jones, C., Olson-Rutz, K., 2017. Soil pH and Organic Matter. Nutrient management module No. 8. M.S. University. Extension Communications Coordinator, 135 Culbertson Hall, Montana State University, Bozeman MT 59717: 16.

Mohanty, B., Gupta, A., Das, B.S., 2016. Estimation of weathering indices using spectral reflectance over visible to mid-infrared region. Geoderma. 266(Supplement C), 111-119.

Mulder, V.L., Plötze, M., de Bruin, S., Schaepman, M.E., Mavris, C., Kokaly, R. F., Egli, M., 2013. Quantifying mineral abundances of complex mixtures by coupling spectral deconvolution of SWIR spectra $(2.1-2.4 \mu \mathrm{m})$ and regression tree analysis. Geoderma. 207-208(Supplement C), 279-290.

Nguyen, H.T., Lee, B.W., 2006. Assessment of rice leaf growth and nitrogen status by hyperspectral canopy reflectance and partial least square regression. European J ournal of Agronomy. 24(4), 349-356.

Paré, T., Dinel, H., Moulin, A.P., Townley-Smith, L., 1999. Organic matter quality and structural stability of a Black Chernozemic soil under different manure and tillage practices. Geoderma. 91(3), 311-326.

Pasakarnis, T., McCormick, M.L., Parkin, G.F., Thompson, A., Scherer, M.M., 2015. Fe-aq(II)-Fe-oxide(III) oxide electron transfer and Fe exchange: effect of organic carbon. Environmental Chemistry. 12(1), 52-63.

Pedersen, H.D., Postma, D., Jakobsen, R., Larsen, O., 2005. Fast transformation of iron oxyhydroxides by the catalytic action of aqueous Fe( II). Geochimica Et Cosmochimica Acta. 69(16), 3967-3977.

PerkinElmer, I., 2018. Sensitivity, Background, Noise, and Calibration in Atomic Spectroscopy: Effects on Accuracy and Detection Limits. 1-11.

Pires, L.F., Villanueva, F.C.A., Dias, N.M.P., Bacchi, O.O.S., Reichardt, K., 2011. Chemical migration during soil water retention curve evaluation. Anais da Academia Brasileira de Ciencias. 83(3), 1097-1107. 
Monitoring soil surface mineralogy at different moisture conditions using Visible Near$\underline{\text { Infrared spectroscopy data }}$

Qafoku, N.P., 2015. Climate-Change Effects on Soils: Accelerated Weathering, Soil Carbon, and Elemental Cycling. Advances in Agronomy, Vol 131. D.L. Sparks. San Diego, Elsevier Academic Press Inc. 131, 111-172.

Qin, J., Burks, T.F., Ritenour, M.A., Bonn, W.G., 2009. Detection of citrus canker using hyperspectral reflectance imaging with spectral information divergence. Journal of Food Engineering. 93(2), 183-191.

Raous, S., Becquer, T., Garnier, J., Martins, E.D., Echevarria, G., Sterckeman, T., 2010. Mobility of metals in nickel mine spoil materials. Applied Geochemistry. 25(11), 1746-1755.

Regelink, I.C., Stoof, C.R., Rousseva, S., Weng, L., Lair, G.J., Kram, P., Nikolaidis, N.P., Kercheva, M., Banwart, S., Comans, R.N.J., 2015. Linkages between aggregate formation, porosity and soil chemical properties. Geoderma. 247-248(Supplement C), 24-37.

Regelink, I.C., Weng, L., Koopmans, G.F., Van Riemsdijk, W.H., 2013. Asymmetric flow field-flow fractionation as a new approach to analyse iron(hydr)oxide nanoparticles in soil extracts. Geoderma. 202, 134- 141.

Remusat, L., Hatton, P.J., Nico, P.S., Zeller, B., Kleber, M., Derrien, D., 2012. NanoSIMS Study of Organic Matter Associated with Soil Aggregates: Advantages, Limitations, and Combination with STXM. Environmental Science \& Technology. 46(7), 3943-3949.

Richards, J., 1993. Remote Sensing Digital Image Analysis, An Introduction Springer-Verlag.

Richter, N., Jarmer, T., Chabrillat, S., Oyonarte, C., Hostert, P., Kaufmann, H., 2009. Free Iron Oxide Determination in Mediterranean Soils using Diffuse Reflectance Spectroscopy. Soil Science Society of America J ournal. 73(1), $72-$ 81.

Righi, D., Petit, S., Bouchet, A., 1993. Characterization of hydroxy-interlayered vermiculite and illite- smectite interstratified minerals from the weathering of chlorite in a cryorthod. Clays and Clay Minerals. 41(4), 484-495.

Rumpel, C., Baumann, K., Remusat, L., Dignac, M.F., Barre, P., Deldicque, D., Glasser, G., Lieberwirth, I., Chabbi, A., 2015. Nanoscale evidence of contrasted processes for root-derived organic matter stabilization by mineral interactions depending on soil depth. Soil Biology \& Biochemistry. 85, 82-88.

Sarathjith, M.C., Das, B.S., Vasava, H.B., Mohanty, B., Sahadevan, A.S., Wani, S.P., Sahrawat, K.L., 2014. Diffuse Reflectance Spectroscopic Approach for the Characterization of Soil Aggregate Size Distribution. Soil Science Society of America J ournal. 78(2), 369-376.

Scheidegger, A., Borkovec, M., Sticher, H., 1993. Coating of silica sand with goethite: preparation and analytical identification. Geoderma. 58(1), 43-65.

Six, J., Elliott, E. T., Paustian, K., 2000. Soil structure and soil organic matter: II. A normalized stability index and the effect of mineralogy. Soil Science Society of America J ournal. 64(3), 1042-1049.

Specim., Spectral I maging Ltd. from www. specim. fi.

Sunil, B.M., Deepa, A.V., 2016. Influence of Drying Temperature on Three Soils Physical Properties. Geotechnical and Geological Engineering. 34(3), 777-788. Tamrat, W.Z., Rose, J., Grauby, O., Doelsch, E., Levard, C., Chaurand, P., Basile-Doelsch, I., 2018. Composition and molecular scale structure of nanophases formed by precipitation of biotite weathering products. Geochimica Et Cosmochimica Acta. 229, 53-64. 
Taylor, R.M., Schwertmann, U., 1974. Maghemite in soils and its origin .1. Properties and observations on soil maghemites. Clay Minerals. 10(4), 289298.

Thompson, A., Chadwick, O.A., Rancourt, D.G., Chorover, J., 2006. Iron-oxide crystallinity increases during soil redox oscillations. Geochimica Et Cosmochimica Acta. 70(7), 1710-1727.

Thompson, A., Rancourt, D.G., Chadwick, O. A., Chorover, J., 2011. Iron solidphase differentiation along a redox gradient in basaltic soils. Geochimica Et Cosmochimica Acta. 75(1), 119-133.

Totsche, K. U., Amelung, W., Gerzabek, M. H., Guggenberger, G., Klumpp, E., Knief, C., Lehndorff, E., Mikutta, R., Peth, S., Prechtel, A., Ray, N., KogelKnabner, I., 2018. Microaggregates in soils. Journal of Plant Nutrition and Soil Science. 181(1), 104-136.

Tratnyek, P. G., Johnson, R.L., 2006. Nanotechnologies for environmental cleanup. Nano Today. 1(2), 44-48.

USGS., 2017. Digital Spectral Library. Retrieved (accessed 4 September 2017), from https://crustal.usgs.gov.

van der Meer, F., 2006. The effectiveness of spectral similarity measures for the analysis of hyperspectral imagery. International J ournal of Applied Earth Observation and Geoinformation. 8(1), 3-17.

Vogel, C., Mueller, C.W., Höschen, C., Buegger, F., Heister, K., Schulz, S., Schloter, M., Kögel-Knabner, I., 2014. Submicron structures provide preferential spots for carbon and nitrogen sequestration in soils. Nature Communications. 5, 2947.

Welch, S. A., Ullman, W.J., 1993. The effect of organic-acids on plagioclase dissolution rates and stoichiometry. Geochimica Et Cosmochimica Acta. 57(12), 2725-2736.

Wogelius, R.A., Walther, J.V., 1991. Olivine dissolution at 25-degrees-Ceffects of $\mathrm{Ph}, \mathrm{CO} 2$, and organic-acids. Geochimica Et Cosmochimica Acta. 55(4), 943-954.

Wolska, E., Schwertmann, U., 1989. The vacancy ordering and distribution of aluminium ions in Gamma-(FE, AL)203. Solid State Ionics. 32-3, 214-218.

Xie, X.L., Pan, X.Z., Sun, B., 2012. Visible and Near-Infrared Diffuse Reflectance Spectroscopy for Prediction of Soil Properties near a Copper Smelter. Pedosphere. 22(3), 351-366.

Xu, M.M., Zhang, L.P., Du, B., 2015. An Image-Based Endmember Bundle Extraction Algorithm Using Both Spatial and Spectral Information. I eee J ournal of Selected Topics in Applied Earth Observations and Remote Sensing. 8(6), 2607-2617.

Ymeti, I., van der Werff, H., Shrestha, D.P., Jetten, V.G., Lievens, C., van der Meer, F., 2017. Using Color, Texture and Object-Based Image Analysis of MultiTemporal Camera Data to Monitor Soil Aggregate Breakdown. Sensors. 17(6). Zaher, H., Caron, J., Ouaki, B., 2005. Modeling aggregate internal pressure evolution following immersion to quantify mechanisms of structural stability. Soil Science Society of America J ournal. 69(1), 1-12.

Zavala, L.M., Granged, A.J.P., Jordán, A., Bárcenas-Moreno, G., 2010. Effect of burning temperature on water repellency and aggregate stability in forest soils under laboratory conditions. Geoderma. 158(3), 366-374.

Zhang, X.C., Norton, L.D., 2002. Effect of exchangeable Mg on saturated hydraulic conductivity, disaggregation and clay dispersion of disturbed soils. Journal of Hydrology. 260(1), 194-205. 
Monitoring soil surface mineralogy at different moisture conditions using Visible NearInfrared spectroscopy data

Zhao, H.Q., Zhao, X.S., Cen, Y., Yang, H., 2017. Research on the Impact of Absorption Feature Extraction on Spectral Difference Between Similar Minerals. Spectroscopy and Spectral Analysis. 37(3), 869-874. 
4 Monitoring the effect of freeze-thaw cycles on soil surface mineralogy using proximal spectroscopy data 
Monitoring the effect of freeze-thaw cycles on soil surface mineralogy using proximal spectroscopy data

\begin{abstract}
Alterations in soil stability are related to the organic and inorganic binding agents. However, the mechanisms triggering the soil stability alteration under freeze-thaw are not fully understood. The freeze-thaw process damages the soil particle binding by reducing the content of mineral components in the soil. Therefore, understanding the soil mineralogical behaviour to freeze-thaw cycles over a short period is essential. The soil mineralogical changes occurring due to the freeze-thaw process can be detected using the Visible Near-I nfrared imaging spectroscopy. It is hypothesized that the freeze-thaw process affects the soil surface mineralogy when the soil is exposed to different moisture conditions. For eight weeks, under laboratory conditions, imaging spectroscopy data were collected on a $72 \mathrm{~h}$ basis for three Silty Loam soils varying in the organic matter (no, low and high) and moisture conditions (field capacity and waterlogging) exposed to freeze-thaw cycles. Using the Spectral Information Divergence image classifier, the image area occupied by the Mg-clinochlore, goethite, quartz coated $50 \%$ by goethite, hematite dimorphous with maghemite was detected and quantified (percentage). The results showed that these minerals behaved differently under freeze-thaw cycles, depending on the soil type and soil condition. While the $\mathrm{Mg}$-clinochlore, goethite and quartz coated $50 \%$ by goethite behaviour depended on the presence of organic matter, the hematite dimorphous with maghemite showed not such a dependence. Likewise, the type of organic matter is vital in soil experiencing freeze-thaw cycles. Moreover, the field capacity and waterlogging conditions significantly impact mineral behaviour under freeze-thaw cycles regardless of the soil type. Using imaging spectroscopy data on the Silty Loam soil, it is showed that the surface mineralogy changes over time due to freeze-thaw cycles, depending on the soil type and the moisture conditions.
\end{abstract}

\title{
4.1 Introduction
}

The freeze-thaw process damages soil particle binding by reducing mineral components' content in the soil (Dagesse, 2013; Jabro et al., 2014). The effect of freeze-thaw cycles on the soil stability depends on many factors such as the soil texture, organic matter (OM) content, clay minerals, initial aggregate size, water content at the freezing time, number of freeze-thaw cycles and freezing temperature (Bajracharya et al., 1998; Li and Fan, 2014; Oztas and Fayetorbay, 2003).

The ice formation rejects the organic and inorganic solutes from ice crystals, causing these solutes' concentration in the freezing front (Kuo et al., 2011; Takenaka et al., 1996). The movement of dissolved salts and elements towards the freezing front occur due to hydrostatic gradient (Shafique et al., 2016). Due to solutes concentration during freezing, the precipitation of secondary minerals in the soil might occur (Blackwell et al., 2010). Therefore, the soil water content and the freezing temperature control the rate at which the soils' physical and chemical properties change (Torrance et al., 2008; Wang and Wu, 2013). The prolonged temperatures below $0{ }^{\circ} \mathrm{C}$ under saturation conditions lead to a decrease in cation exchange capacity (CEC) following an increase of 
the cations leaching in the soil ( $\mathrm{Li}$ et al., 2016). As a result, the cations adsorbed on soil lowered as the number of freeze-thaw cycles increased because the divalent cations binding weakened (Dang et al., 2012). Likewise, it has been shown that due to the freeze-thaw cycles, the soil OM content and $\mathrm{pH}$ value are lower compared to the unfrozen soil (Herndon et al., 2015; Lee et al., 2012; Pokrovsky et al., 2018). Consequently, the increased number of freeze-thaw cycles accelerates the decrease in these soil properties. The low soil $\mathrm{pH}$ increases $\mathrm{H}^{+}$ion, which competes with polyvalent minerals for the binding side, decreasing the soil surface negative charges (Kim, 2014).

Moreover, the increase of $\mathrm{H}^{+}$stimulates the redox reactions reducing the free iron oxide content in a soil environment. This reduction of free iron oxide has a negative impact on the adsorption of cations in soils. Likewise, the degradation of the OM and the release of dissolved organic acids, as a result of freeze-thaw cycles, decrease the soils' adsorption capacity (Freppaz et al., 2007). The decrease of the dissolved Fe, Al, Si, Mg, Ca due to freeze-thaw cycles suggest precipitation of $\mathrm{Fe}, \mathrm{Al}$ hydroxide, and amorphous aluminosilicates (Emerson et al., 2015; Kim and Choi, 2018; Mohanty et al., 2014). However, Song et al., (2017) pointed out that due to the ice crystals, the soil aggregates break, increasing their specific surface area and adsorption capacity.

Soil texture plays a significant role in the freeze-thaw process since in soils with high clay content, the freezing is faster than the thawing process. On the other hand, in soils with high sand content, there is no distinction in time between freezing and thawing (Stahli and Stadler, 1997). Moreover, the soils with high silt content are more susceptible to freezing because the silty soils stimulate the ice lenses' formation.

Both active and passive microwave sensors can provide information on the freeze-thaw state on the soil surface. Due to the freeze-thaw process, the soil surface dielectric alterations can be detected using passive microwave sensors. Long wavelengths such as L-band are widely used for soil freeze-thaw monitoring because of their high sensitivity to liquid water change and penetration depth into the soil (Rautiainen et al., 2016; Rowlandson et al., 2018; Roy et al., 2015). Since the passive microwave sensors capture the changes in soil water state and the thermal infrared sensors retrieve the land surface temperature, the fusion of these data is used to identify the freezethaw on the ground (Kou et al., 2017; Zhao et al., 2017).

The X-ray tomography (XRT) technique has been used to investigate the effect of freeze-thaw on soil structural changes (Starkloff et al., 2017; Torrance et al., 2008). Naegeli et al., (2015) used imaging spectroscopy data to distinguish different materials present on a glacier surface. Using the Spectral Angular Mapper (SAM) algorithm, their results showed that both in-situ and airborne imaging spectrometer data allow identifying the distribution, composition and impact of light-absorbing impurities on glacier surfaces. Another study classified snow and bare ice classes from Hyperion data using the Support Vector Machines (SVM) algorithm providing user's accuracies of 90 and $70 \%$, respectively (Di Mauro et al., 2017).

Due to the freeze-thaw, the soil coarse and fine particles' fragmentation and aggregation occur, respectively. Therefore, the freeze-thaw process alters the initial soil structure (Zhang et al., 2016). Many studies have reported that the freeze-thaw cycles break down the aggregates leading to decreased aggregate stability (Li et al., 2019; Song et al., 2017). Alterations in soil stability are 
Monitoring the effect of freeze-thaw cycles on soil surface mineralogy using proximal spectroscopy data

related to the organic and inorganic binding agents. Indeed, it was found that freeze-thaw cycles cause soil organic carbon loss affecting soil stability (Tang et al., 2016). However, Li et al., (2019) pointed out that the mechanisms triggering the soil stability alteration under freeze-thaw are not fully understood. Soil is composed of the variability of minerals having their behaviour under freeze-thaw cycles. Therefore, understanding the soil mineralogical reactions to freeze-thaw cycles over a short period is essential. Using the Visible Near-I nfrared (VNIR) imaging spectroscopy approach, the soil mineralogical changes occurring due to the freeze-thaw process can be detected. Repeated freeze-thaw cycles might encourage migration and alter the soil matrix's chemical constituents exposed to different moisture conditions. Therefore, this study aimed to investigate the effect of freeze-thaw cycles on the soil surface mineralogy at different moisture content. What is the impact of the freeze-thaw process on soil mineralogy when the soil is at the field capacity and waterlogging conditions? Moreover, how much does the percentage of the soil surface mineralogy changes over time due to the freezethaw cycles? It is hypothesized that the freeze-thaw process triggers soil mineral precipitation, dissolution and release. Silty Loam soil samples varying in the organic matter (no, low and high) and moisture conditions (field capacity and waterlogging) exposed to freeze-thaw cycles were scanned in laboratory conditions at a micro-plot scale at 72 hours basis using an imaging spectrometer camera for eight weeks.

\subsection{Materials and methods}

\subsubsection{Experimental setup}

A laboratory experiment consisting of an imaging spectrometer camera, a light source and a sliding table integrated into a fixed setup was designed to investigate the effect of freeze-thaw cycles on the soil surface mineralogy at various $\mathrm{OM}$ and moisture content. Also, on the sliding table, a tray filled with soil was placed. Silty Loam soils dominated by silt particles are one of the subdivisions of the loam soils. The Silty Loam soils support a considerable variability of plant life because the OM content and soluble nutrients occur in the silt particles. However, these soils are also susceptible to various environmental stresses. Therefore, these soil types need special attention. Two soil samples, Silty Loam with a low and high amount of OM content (Soil 2 and Soil 3), were collected from topsoil $(20 \mathrm{~cm})$ of agricultural fields in Limburg, the Netherlands. The agricultural crop cultivated in both fields was maize. However, at the time of soil sampling, this crop was already harvested. These soil samples were collected at the end of September 2014.

The Silty Loam soils were chosen because it was found that freeze-thaw cycles cause the soil aggregate breakdown (Ymeti et al., 2017). The other soil sample was obtained by destroying the OM of Soil 2 by heating it at $550{ }^{\circ} \mathrm{C}$ for at least $12 \mathrm{~h}$. The new soil sample with no OM was identified as Soil 1. Besides the loss of $\mathrm{OM}$ at $550{ }^{\circ} \mathrm{C}$, the clay mineral kaolinite decomposes above this temperature leading to the amorphous alumino-silicate material (Zavala et al., 2010). Likewise, the soil mineral goethite transforms to hematite or maghemite at a 
temperature ranging from $250{ }^{\circ} \mathrm{C}$ to $420^{\circ} \mathrm{C}$ (Hanesch et al., 2006; Liu et al., 2013). However, these mineralogical alterations of Soil 1 were out of the scope of this study. Each of these soil samples was duplicated. Table 4-1 summarized the soil characteristics used in this study.

Table 4-1. The soils used in this study. Soils 2-3 (low and high organic matter $(\mathrm{OM})$ ) were collected from Limburg province in The Netherlands. Soil 1 (no OM) was obtained from Soil 2.

\begin{tabular}{lccccc}
\hline Soil ID & \multicolumn{2}{c}{ Soil particle size (\%) } & Texture class & OM (\%) \\
& Clay & Silt & Sand & & \\
\hline Soil 1 & 16 & 71 & $13^{1}$ & Silty Loam & $0^{2}$ \\
Soil 2 & 16 & 71 & 13 & Silty Loam & 4.6 \\
Soil 3 & 23 & 52 & 25 & Silty Loam & $12.3^{3}$ \\
\hline
\end{tabular}

1The determination of the soil particle size was only performed before the soil sample was placed at $550{ }^{\circ} \mathrm{C}$. ${ }^{2}$ The OM was determined by heating the sample at $550{ }^{\circ} \mathrm{C}$ for more than $12 \mathrm{~h}$ and calculating the weight loss on the dry soil. ${ }^{3}$ The high OM content in Soil 3 is probably coming from sewage sludge manure mixed with plant residues application by the farmer some days before soil sample was taken.

During the freezing process, the ice formation leads to solute accumulation at the freezing front. As a result, the supersaturated solution promotes the precipitation of secondary minerals in the soil. The soil at the waterlogging state generates ice with strong expanding forces. These forces are expected to break inter-particle bonds in the soil. However, in the soil at field capacity, the ice crystals grow in the soil pores (Ferrick and Gatto, 2005). It is expected that the freeze-thaw process triggers more mineral precipitation and release in soils at the waterlogging compared to field capacity condition. Therefore, in this study, two separate experimental setups were carried out. In the first experiment, the soil samples kept at the field capacity (FC) were exposed to the freeze-thaw cycles. The second experiment had the soil samples at the waterlogging (WL) condition placed at the freeze-thaw cycles.

Each experimental setup had its own set of soil samples duplicated (Soil 1-Soil 3). Twelve plastic trays of $15 \times 9 \times 1 \mathrm{~cm}^{3}$ were filled manually with soil using a small shovel. As a result, the soil aggregates of various sizes occurred in the tray. The air-dried soils were weighted using a balance. Deionized water at the edge of the trays was added to place them at the field capacity. The amount of water required for this procedure was different, depending on the soil type. Two hundred $\mathrm{ml}$ and $300 \mathrm{ml}$ of deionized water were added to set the Soil 1 and Soil 2-3 to the FC conditions, respectively. Afterwards, the six soil samples were lifted to allow the excess water to leak out. They were considered at the FC when the leaking process had stopped. Next, the soil samples were placed in the freezer at $-20{ }^{\circ} \mathrm{C}$ for $72 \mathrm{~h}$. Then, they were taken out and left thawing for the next $72 \mathrm{~h}$ at room temperature $\left(+20^{\circ} \mathrm{C}\right)$. After $72 \mathrm{~h}$ at room temperature, the FC soil samples were placed again in the freezer at $-20{ }^{\circ} \mathrm{C}$ for the next $72 \mathrm{~h}$. This exchange between the freeze and thaw conditions was repeated until the end of the experiment.

The other six soil samples were placed at the waterlogging conditions by saturating them with $410 \mathrm{ml}$ and $560 \mathrm{ml}$ deionized water for Soil 1 and Soil 23 , respectively. Next, they were carefully placed in the freezer $\left(-20^{\circ} \mathrm{C}\right)$ for 72 
Monitoring the effect of freeze-thaw cycles on soil surface mineralogy using proximal spectroscopy data

h. Later, the soil samples were left thawing at room temperature $\left(+20^{\circ} \mathrm{C}\right)$ for the next $72 \mathrm{~h}$. Afterwards, they were placed again in the freezer for $72 \mathrm{~h}$ making sure that they were in the waterlogging conditions. This procedure was repeated for eight weeks that the experiment ran.

Drainage was enabled by $5 \mathrm{~mm}$ diameters holes drilled at the bottom of the tray to place the soil samples at the FC state. Likewise, the pantyhose filters were used to avoid the soil leaking out. Moreover, to eliminate any external influence on the soil samples, they were covered with a plastic lid. Furthermore, the freezer's space limitation forced us to place the soil samples on top of each other.

Twelve soil samples with various OM content (no, low and high) at the FC and WL treatments were scanned by the VNIR imaging spectrometer camera every $72 \mathrm{~h}$, as shown in Figure 4-1. Images were collected for eight weeks. The decision of eight weeks experiment was related to the laboratory facilities.

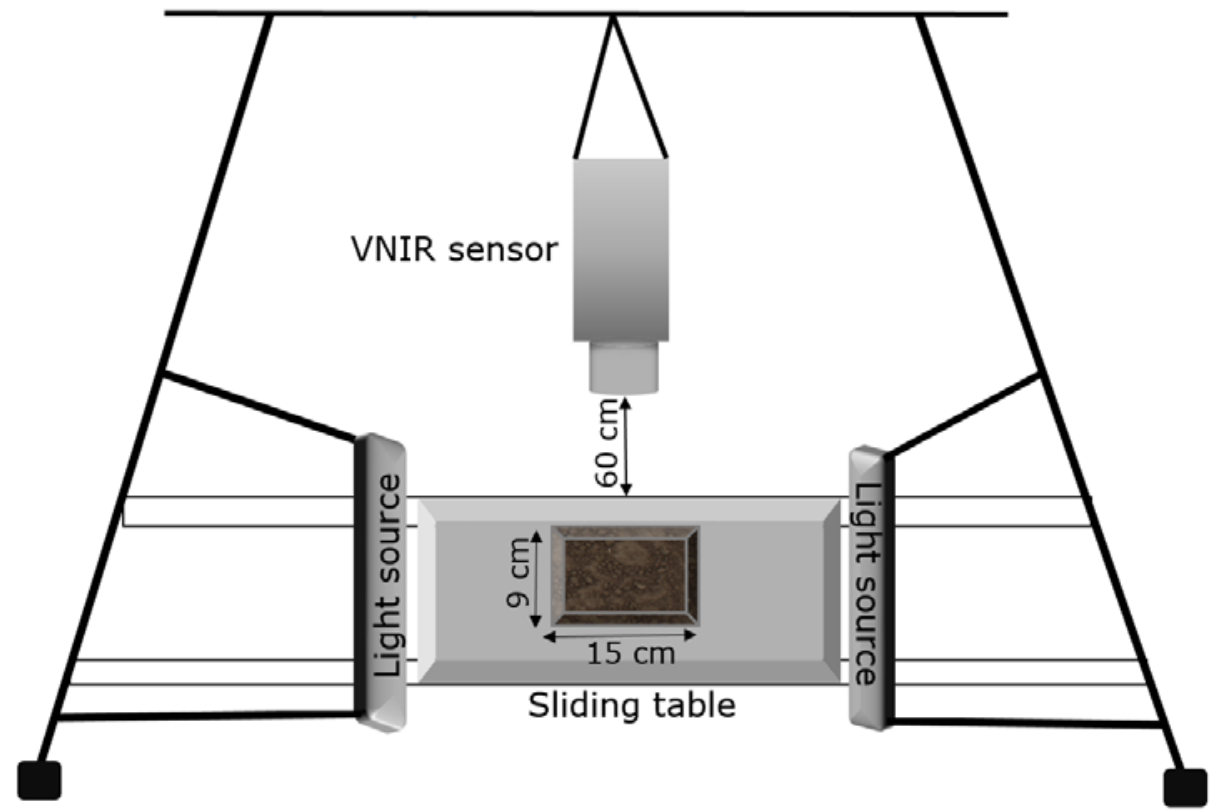

Figure 4-1. Schematic design of the experimental laboratory setup for image data collection. On the tripod in the centre is the VNIR imaging spectrometer camera placed at an angle of $90^{\circ}$. Next to the sensor is a sliding table where the soil tray is placed for scanning. On the right and the left side of the sliding table, an external light source is integrated to illuminate the tray during image acquisition.

\subsubsection{Image acquisition}

A Specim imaging spectrometer camera was used to investigate mineralogical changes on the soil surface due to freeze-thaw cycles under controlled 
laboratory conditions. This camera works as a push broom scanner and provides contiguous spectral information for each pixel (see https://www.specim.fi/ for detailed information).

The camera was placed at an angle of $90^{\circ}$, making a perpendicular capture of the tray at a distance of approximately $60 \mathrm{~cm}$ between the soil tray and the sensor. Also, the tray was illuminated by a lighting source, integrated into the Specim setup system. All the other light sources were switched off to minimize any influence of the external light. The Specim spectrometer camera operating in VNIR acquires data in the $391 \mathrm{~nm}$ to $1000 \mathrm{~nm}$ spectral range providing 784 spectral bands with a spectral resolution ranging from $0.75 \mathrm{~nm}$ to $0.82 \mathrm{~nm}$ and the spatial pixels of 1024 . The raw data were converted to absolute reflectance using the reflectance factors of the manufacturer's calibration panel.

The images were selected, avoiding the shadow and the edge, as shown in Figure 4-2. The image of $200 \times 200$ pixels of VNIR corresponds to a $72 \times 72$ $\mathrm{mm}^{2}$ area with a spatial resolution of $2.8 \mathrm{~mm} /$ pixels.

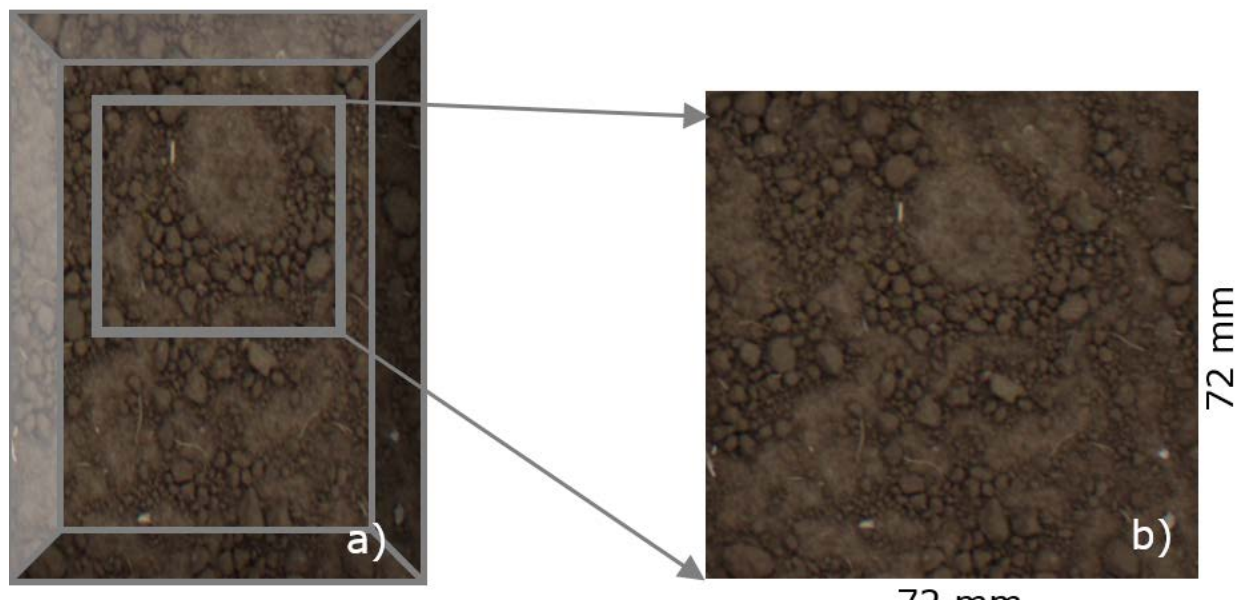

$72 \mathrm{~mm}$

Figure 4-2. Example of an image selected for analysis. In order to avoid shadow, the VNIR image was selected from the upper (a) part of the tray. The image subset of $72 \times 72 \mathrm{~mm}^{2}$ with a pixel size of $2.8 \mathrm{~mm} /$ pixels (b) was obtained.

\subsubsection{Image processing}

Although the spectroscopy data provide useful information for identifing various materials with similar spectral properties, they suffer from highly correlated and noisy spectral bands (Nguyen and Lee, 2006; Van der Meer and Jia, 2012; Mariotto et al., 2013). Therefore it was considered necessary to perform image processing before further data analysis. The noisy bands ranging from $391 \mathrm{~nm}$ to $420 \mathrm{~nm}$ and $951 \mathrm{~nm}$ to $1008 \mathrm{~nm}$ of the VNIR sensor were discarded due to a low signal to noise ratio (Butz et al., 2015). Although the images were spectrally resized, their dimensionality was high ( 676 bands). The processing of the enormous amount of hyperspectral data might be problematic, leading to high computational cost. The spectral binning was used 
Monitoring the effect of freeze-thaw cycles on soil surface mineralogy using proximal spectroscopy data

by averaging every four adjacent bands, i.e., binning was set to four to decrease redundant and correlated spectral bands (Ymeti et al., 2019). As a result, the spectral dimensionality reduced from 676 to 169 (bands).

Gaussian stretch was performed to normalize the images. The idea was to achieve a stretched brightness value distribution which resembles a normal distribution where tails were clipped to \pm 2 standard deviations. The image normalization allows the investigation of soil mineralogical changes over time. The image-processing tools based on multivariate techniques, such as the principal component analysis (PCA), are applied for extracting useful information. The PCA involves a linear decomposition of the original dataset into a new coordinate system based on the eigenvectors and principal components (PC) (Richards, 1993). There can be as many PCs as the number of spectral bands in the original image. However, the first two PCs contain the highest spectral and spatial data variability (J elenek et al., 2016).

The rest of the PCs obtain mostly noise (useless information). Implementing the forward PC rotation, the first two PCs that contained 99\% of the data variability were selected (ENVI, 2015). However, the PC images do not allow identification and quantification of the soil mineralogical changes. Therefore, the transformation of the PC images back into their original data space was completed.

\subsubsection{Spectral information divergence approach (SID)}

The key to imaging spectroscopy classification is the assessment of the spectral similarity of various objects. An image pixel is usually a mixture of different materials with various abundance fractions. Therefore, the sensor's high spectral resolution (hundreds of spectral bands) does allow resolving these mixtures better than the low spectral resolution. Consequently, this pixel's spectral information is essential for material discrimination, detection, identification, and classification (Xu et al., 2015; Zhao et al., 2017). The goal was to identify and quantify the soil surface mineralogy alterations due to freeze-thaw cycles at the field capacity and waterlogging conditions. Therefore, the Spectral Information Divergence (SID) spectral similarity approach was used. The SID stochastic classifier provides more accurate results than empirical methods (Qin et al., 2009; van der Meer, 2006). The SID uses a divergence measure to match pixels spectra to reference spectra. The more pixels are similar, the smaller the divergence. Pixels are not classified when the divergence measure is greater than the specified maximum divergence threshold. The SID measures a single mixed pixel's spectral variability where each pixel is considered a random variable and uses its spectral histogram to define a probability distribution (Chang, 2000). Considering two spectral vectors, spectral reference $r=(r 1, r 2 \ldots r N)$ and an unknown spectral image $u$ $=(u 1, u 2 \ldots . u N)$ the SID is calculated based on relative entropy.

Thus, $\operatorname{SID}(r, u)=D(r \| u)+D(u \| r)$

where $\mathrm{D}(\mathrm{r} \| \mathrm{u})=-\sum_{i=1}^{N} p i \log \left(\frac{p i}{q i}\right), \mathrm{D}(\mathrm{u} \| \mathrm{r})=-\sum_{i=1}^{N} q i \log (q i / p i)$

and $\mathrm{p}_{\mathrm{i}}=\mathrm{ri} / \sum_{i=1}^{N} \mathrm{ri}, \mathrm{qi}=\mathrm{ui} / \sum_{i=1}^{N} u i$ 
$\mathrm{N}$ is the number of bands, the symbol $\|$ represents both the relative entropy of $u$ with respect to $r$ and the relative entropy of $r$ with respect to $u$.

The SID spectral information was obtained from the United States Geological Survey (USGS) spectral library (USGS, 2017). This spectral information corresponds to minerals identified by X-ray diffraction analysis on the clay fraction. The clay fraction in the soil sample was determined in the laboratory using the pipette method. The X-ray analysis identified a range of minerals such as goethite, hematite, maghemite, Mg-clinochlore, ferroan clinochlore, kaolinite, and muscovite. These minerals are typical of Luvisols developed on a loess deposit (Veer, 2006). However, in the VNIR, the Mg-clinochlore, goethite $125 \mu \mathrm{m}$ grain size, quartz coated $50 \%$ by goethite (Qz-Gt), and hematite dimorphous with maghemite $(\mathrm{Hm}-\mathrm{Mh})$ were identified. The $\mathrm{Hm}-\mathrm{Mh}$ occurred in various grain size intervals (150-250, 60-104, 30-45, 10-20 um). Besides the spectral information, the SID approach requires a maximum divergence threshold. An image with known hematite distribution was used to determine this threshold. By testing various threshold and spectral binning, a threshold value of 0.15 and a spectral binning of four identified the hematite distribution over the image (Ymeti et al., 2019). It is assumed that these parameters (threshold and spectral binning) could identify the minerals existing in any soil image, so the SID classification was performed for all the soil samples using these parameters.

Since each of the SID class had isolated unclassified pixels, a majority postclassification image analysis using a window $3 \times 3$ pixels was carried out. The SID classifier matches pixels to the reference spectra using the divergence threshold. Therefore, the pixel could either have a specific mineral or is unclassified. The percentage of each mineral in each image was calculated based on the pixel count in the image. Here, the number of 40000 pixels corresponded to $100 \%$ of the image in VNIR. Therefore, based on the number of pixels that each mineral occupied in the image, its percentage could be determined. Although the $\mathrm{Hm}$ - Mh percentage was calculated for each grain size interval, its average was used in the results section. Moreover, we summarized the mineral percentages by averaging each soil type's duplicates (Soil 1-Soil 3) placed in each soil at the FC and WL conditions. It is essential to point out that the percentage of these minerals was derived from surface measurements, and the soil depth was not considered.

\subsection{Results}

Applying the USGS spectral library, the minerals identified in the VNIR using the SID classifier belong to the phyllosilicate group, more specifically to chlorite, iron oxide and hydroxide. Figure 4-3 shows the results of the FC soil treatment at the start (week0), middle (week4) and the end of the experiment (week8) in the thawing condition. All the soils showed changes in their minerals distribution over time. 

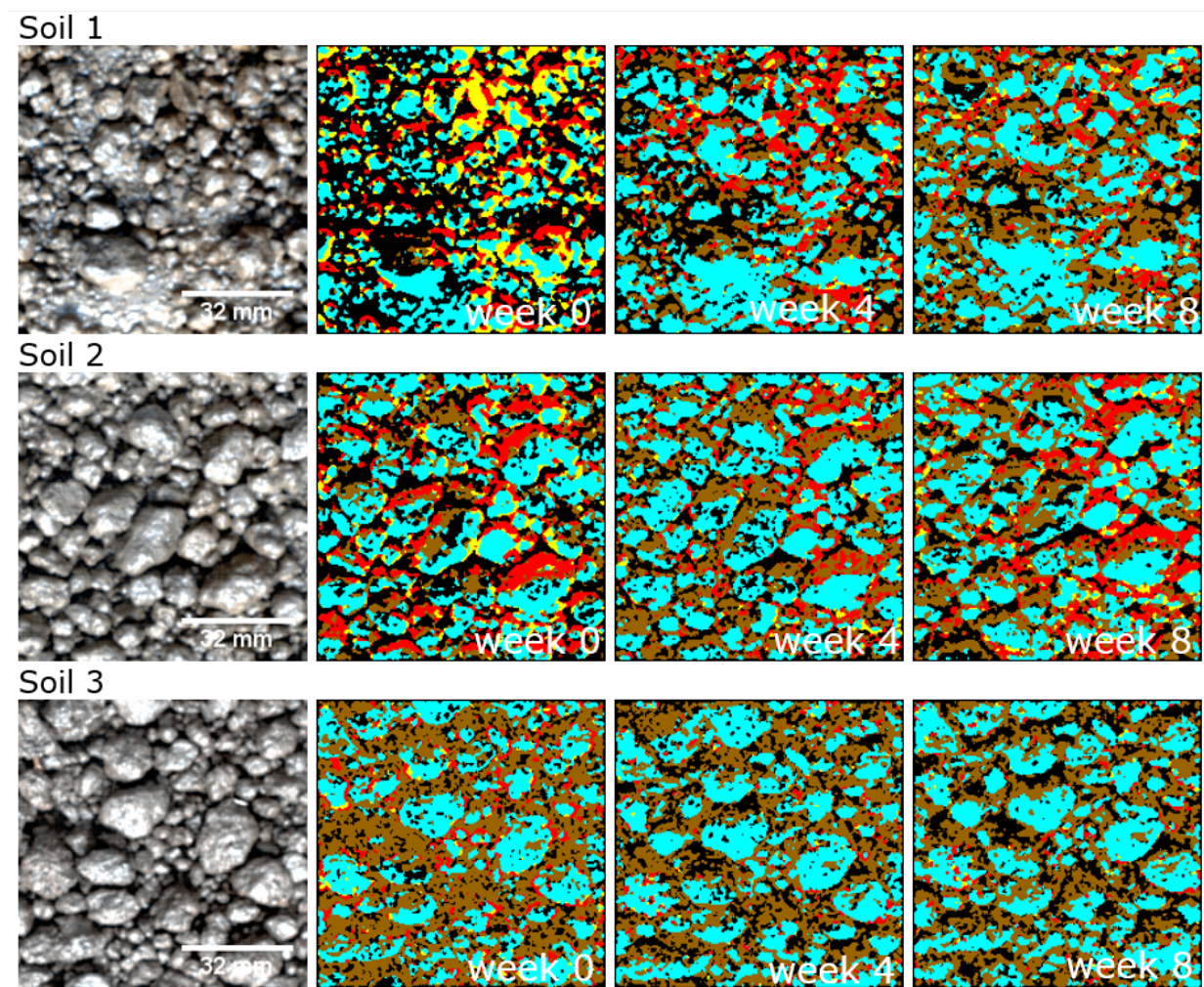

Legend:Mg-clinochlore Goethite $125 \mu \mathrm{m}$ Quartz coated $50 \%$ by goethite(Qz-

$\mathrm{Gt})$ Hematite dimorphous with maghemite ( $\mathrm{Hm}-\mathrm{Mh}) \square$ unclassified

Figure 4-3. Example of the SID classification results at the FC treatment at the start (week0), middle (week4) and the end of the experiment (week8) in the thawing condition (Soil 1- Soil 3). The colours represent the minerals identified in the VNIR. All the soils show changes in their mineral distribution over time. The original images, at the start of the experiment together with the scale bar, are also shown.

\subsubsection{Field capacity condition (FC)}

The result of treatment freezing and thawing after field capacity is shown in Figure 4-4. The result shows that Mg-clinochlore seems to be stable over time in the thawing conditions regardless of OM's presence (Figure 4-4b). However, in the freezing conditions, the percentage of Mg-clinochlore fluctuated over time for all the soils (Soil 1, Soil 2 and Soil 3) (Figure 4-4a).

The goethite $125 \mu \mathrm{m}$ was not detected for Soil 3 (high OM) in the thawing conditions (Figure 4-4d). Moreover, in this condition, the percentage of goethite of Soil 1 and Soil 2, which was $2 \%$, remained stable over time. Oppositely, in the freezing condition, the goethite fluctuated in time for all the soils. However, it stayed unchanged and decreased for Soil 1 and Soil 2-3, 
respectively, in the end, compared to the start of the experiment (Figure 44c).

The Qz-Gt was stable in the thawing condition for Soil 2 and 3. However, the percentage of Qz-Gt of Soil 1 decreased at the end of the experiment (Figure 4-4f). The Qz-Gt increased in the first half of the experiment in the freezing conditions for all the soils. In the second half of the experiment, this mineral seems to stabilize. The stability of the Qz-Gt of Soil 1 was noticeable compared to Soil 2 and Soil 3 (Figure 4-4e).

The behaviour of $\mathrm{Hm}$-Mh for all the soils was similar regardless of the freezing or thawing conditions. For Soil 1 and Soil 2, the Hm-Mh fluctuations were more significant in the freezing compared to thawing conditions. The Hm-Mh of Soil 3 was stable in the thawing conditions. This stability was also observed after week three in the freezing conditions (Figure 4-4g, h).
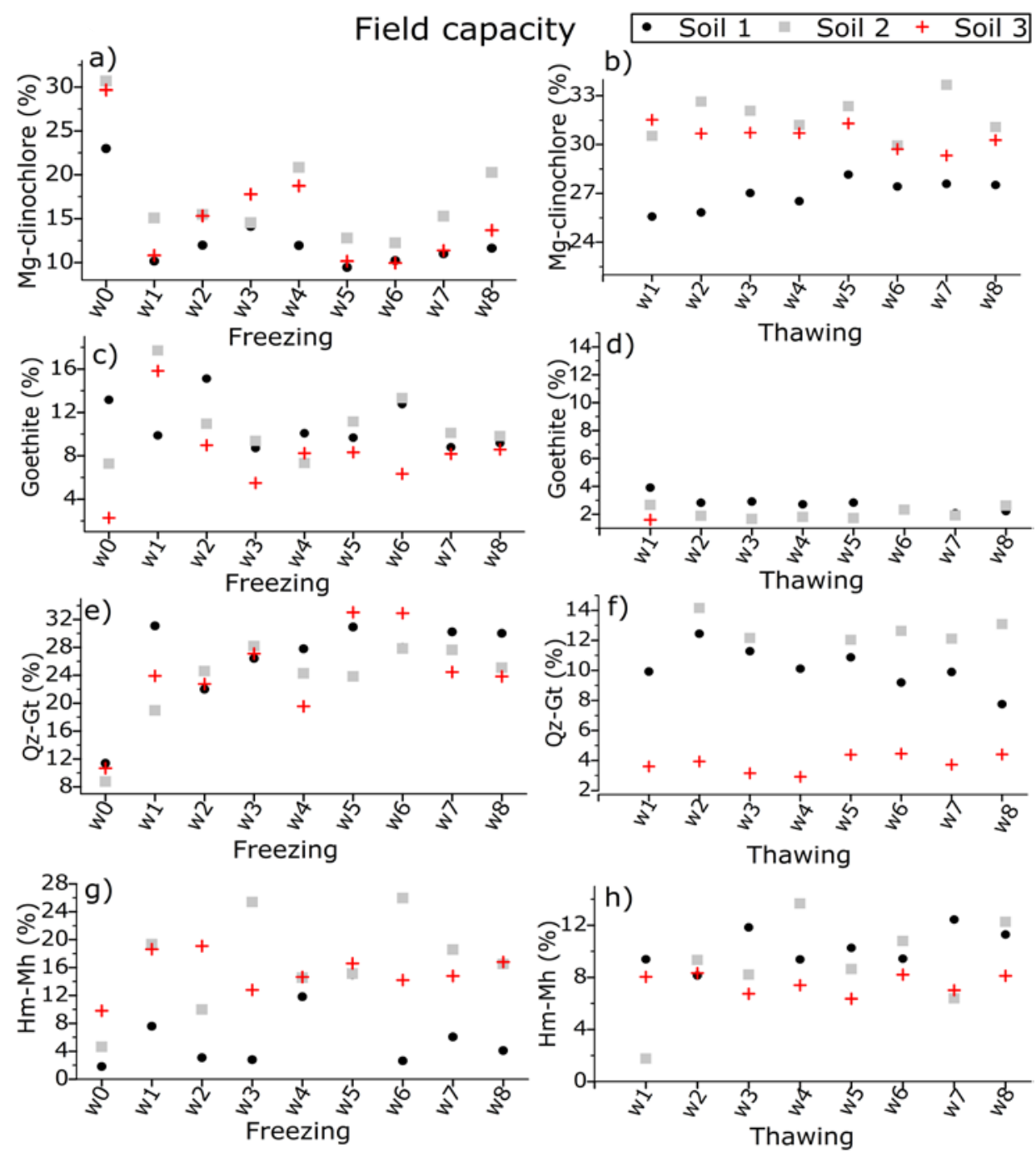
Monitoring the effect of freeze-thaw cycles on soil surface mineralogy using proximal spectroscopy data

Figure 4-4. Average Mg-clinochlore, goethite $125 \mu \mathrm{m}$, quartz coated $50 \%$ by goethite and hematite dimorphous with maghemite changes for all the soils at the FC condition. The circle, square and plus symbols represent Soil 1, Soil 2 and Soil 3, respectively. The vertical axis characterizes the percentage of each mineral occurring in an image. The scale of the $Y$-axis varies from $0 \%$ to $100 \%$. In the horizontal axis, w1,.., w8 stands for week $1, \ldots$, week 8 , when the soil sample was at the freezing and thawing condition. Each mineral percentage is represented in two separate graphs (freezing and thawing) for easy visualization. However, the soil samples were at freezing for three days and the next three days at the thawing conditions making up one week.

\subsubsection{Waterlogging condition (WL)}

The results of the treatment of freezing and thawing after waterlogging are shown in Figure 4-5. The Mg-clinochlore of Soil 1 decreased until week three, and it stabilized for the rest of the experiment regardless of the soil conditions (freeze or thaw). However, this decrease is more noticeable in the thawing compared to freezing conditions. The Mg-clinochlore of Soil 2 fluctuated over time. However, these fluctuations were more evident in the freezing compared to the thawing condition. The Mg-clinochlore of Soil 3 decreased continuously and fluctuated in the thawing and freezing conditions, respectively (Figure 4$5 a, b)$.

The goethite $125 \mu \mathrm{m}$ of Soil 1 fluctuated in the first half of the experiment, and it stabilized afterwards in freezing condition (Figure 4-5c). The goethite of Soil 2 had the same behaviour during freezing and thawing. In the second half of the experiment, it stabilized. The goethite of Soil 3 was relatively stable during freezing and decreased at the thawing conditions (Figure 4-5c, d).

Figure 4-5e, f show that the Qz-Gt of Soil 1 increased and stabilized in the first half and second half of the experiment, respectively, regardless of the soil conditions (freeze or thaw). However, the percentage of Qz-Gt was higher in the freezing compared to the thawing condition. The Qz-Gt of Soil 2 decreased in the freezing conditions. This mineral stayed stable in the thawing conditions. The Qz-Gt of Soil 3 fluctuated with a small magnitude in the freezing conditions. However, in the thawing condition, this mineral tended to decrease at the end of the experiment. Hm-Mh's percentage fluctuated in time for all the soils in the freezing condition (Figure 4-5g). The $\mathrm{Hm}-\mathrm{Mh}$ of Soil 1 and Soil 2 increased and decreased at the end of the experiment in the thawing condition, respectively. The percentage of $\mathrm{Hm}-\mathrm{Mh}$ of Soil 3 decreased and increased during the first half of the experiment in the thawing conditions. Later, it stabilized for the rest of the experiment (Figure 4-5h). 

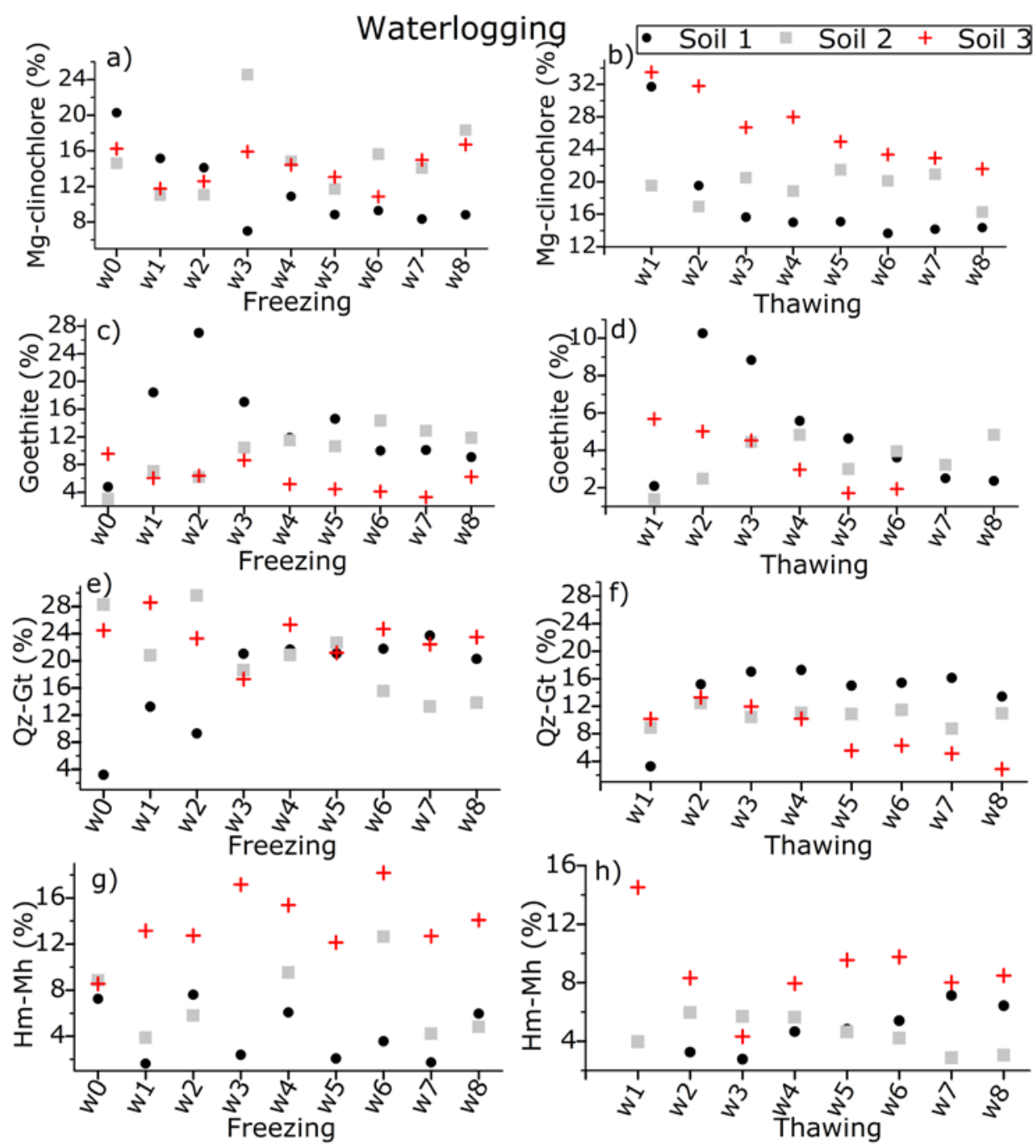

Figure 4-5. Average Mg-clinochlore, goethite $125 \mu \mathrm{m}$, quartz coated $50 \%$ by goethite and hematite dimorphous with maghemite changes for all the soils at the WL condition. The circle, square and plus symbols represent Soil 1, Soil 2 and Soil 3, respectively. The vertical axis characterizes the percentage of each mineral occurring in an image. The scale of the $Y$-axis varies from $0 \%$ to $100 \%$. In the horizontal axis, w1,.., w8 stands for week $1, \ldots$, week 8 , when the soil sample was at the freezing and thawing condition. Each mineral percentage is represented in two separate graphs (freezing and thawing) for easy visualization. However, the soil samples were at freezing for three days and the next three days at the thawing conditions making up one week. 
Monitoring the effect of freeze-thaw cycles on soil surface mineralogy using proximal spectroscopy data

Figure 4-6 summarized minerals' percentage at the start and the end of the experiment when the soils were frozen. At the FC condition, the Mg-clinochlore increased $1.5 \%, 5.2 \%$ and $2.9 \%$ for Soil 1 , Soil 2 and Soil 3 at the end of the experiment, respectively. Soil 2' goethite decreased by $7.9 \%$ at the end of the experiment. However, this mineral might be considered stable for Soil 1 and Soil 3. Qz-Gt percentage decreased for Soil 1 and increased for Soil 2-3 with a small magnitude at the end of the experiment. The $\mathrm{Hm}-\mathrm{Mh}$ percentage decreased at the end of the experiment for all the soils (Figure 4-6a). At the WL condition, the Mg-clinochlore decreased and increased for Soil 1 and Soil 2-3 at the end of the experiment, respectively (Figure 4-6b). A decrease in the goethite of Soil 1 occurred at the end of the experiment, too. On the contrary, this mineral increased and remained stable for Soil 2 and Soil 3. The other mineral, Qz-Gt, increased for Soil 1 and decreased for Soil 2 and 3 at the end of the experiment. The $\mathrm{Hm}-\mathrm{Mh}$ increased at the end of the experiment for all the soils. However, this increase was higher for Soil 1 compared to Soil 2 and 3.
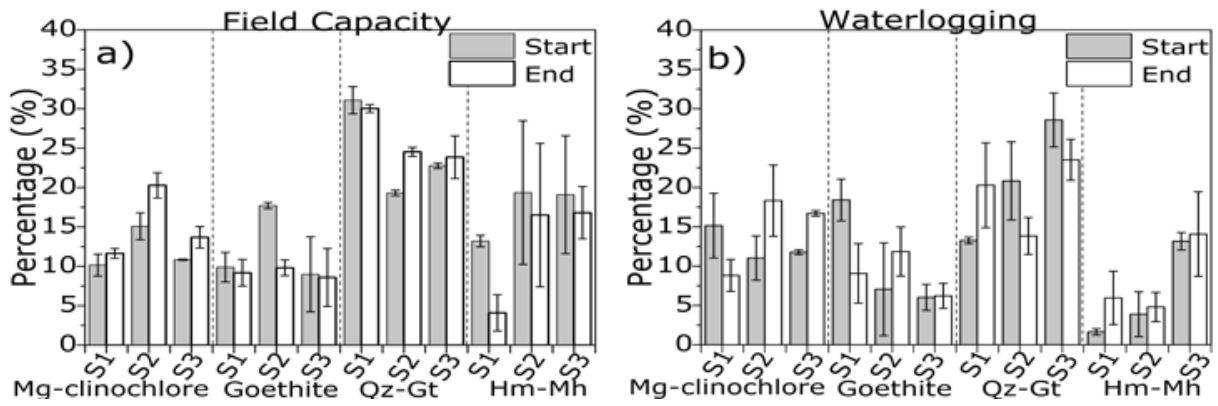

Figure 4-6. The percentage of the minerals when the soil samples were at the freezing treatment. The vertical axis characterizes the percentage of each mineral occurring in an image. The horizontal axis represents the $\mathrm{Mg}$ clinochlore, goethite $125 \mu \mathrm{m}$, quartz coated 50\% with goethite (Qz-Gt) and hematite dimorphous with maghemite (Hm-Mh) of Soil 1 - Soil 3 (S1 - S3) in the field capacity (a) and waterlogging (b) condition at the start and end of the experiment. The error bars represent the standard deviation of the minerals in duplicated soil samples. Since the SID approach disregards the self-shadow areas created by various soil aggregate size, these aggregate variations influenced the standard deviation.

\subsection{Discussion}

The results showed that repeated freeze-thaw cycles affected $\mathrm{Mg}$-clinochlore behaviour depending on the soil type and moisture condition. A significant amount of unfrozen water has been found in the soil matrix at $-20{ }^{\circ} \mathrm{C}$ (Rivkina et al., 2000). This unfrozen water and the Mg cations could move toward the top of the soil, increasing the Mg concentration due to increased potential osmotic gradients (Mohamed et al., 1996). This phenomenon could explain the increase of $\mathrm{Mg}$-clinochlore for Soil 1 and Soil 2 at the FC treatment at the end 
of the experiment. Likewise, it has been shown that the exchangeable $\mathrm{K}, \mathrm{Ca}$, $\mathrm{Mg}$ either decrease in concentration or are unaffected by freeze-thaw cycles (Hinman, 1970). Here, a decrease of Soil 1(no OM) Mg-clinochlore at the WL treatment was observed. The manure present in Soil 3 does not increase the soil cohesion (Paré et al., 1999). Therefore, Mg's leakage and its weak interparticle cohesion lead to a decrease in the Mg-clinochlore at FC treatment. The opposite was observed for the Mg-clinochlore of Soil 2 with low OM. These results suggest that the amount and type of $\mathrm{OM}$ are essential in the soil organic-mineral interactions experiencing the freeze-thaw cycles.

The freezing process causes the solutes' concentration in the freezing front (Kuo et al., 2011; Takenaka et al., 1996). Due to this phenomenon, the concentrated protons could protonate the iron oxide surface, releasing more $\mathrm{Fe}^{3+}$ ions into the freezing front. Another mechanism that encourages dissolved iron release upon freezing is the concentrated organic ligands, which serve as the iron-chelating agents. Indeed, the dissolution rate of goethite and maghemite enhanced due to organic acid. Moreover, it has been shown that the dissolution rate of these iron oxides in ice depends on their surface area (Jeong et al., 2012). Since the goethite has a higher surface area than maghemite and hematite, the former shows a higher concentration of dissolved iron (Kim et al., 2019). Goethite interactions with the mineral surfaces, organic materials and microbial organisms are known (Heckman et al., 2013; Kaiser and Kalbitz, 2012). The chemical composition of the OM determines its sorption capacity to goethite. Therefore, the goethite of Soil 2 and 3 behaved differently under freeze-thaw cycles. Regardless of the soil moisture conditions (FC or WL), the goethite of Soil 3 was not affected by repeated freeze-thaw cycles. This stability of goethite could be related to the origin of OM of Soil 3, which is sewage sludge (hydrophilic) that sorb to goethite. It has been shown that the application of the sewage sludge to soils subjected to freeze-thaw cycles has increased the aggregate stability through binding mechanisms (Angin et al., 2013; Sahin et al., 2008).

The percentage of goethite of Soil 2 with hydrophobic OM depended on the moisture conditions. Repeated freeze-thaw cycles decreased and increased the goethite at FC and WL treatment. In the waterlogging soil conditions, the freeze-thaw process increases soil microbial activity and accelerates the decomposition of organic material and, therefore, reduces the goethite (Chai et al., 2014; Haei et al., 2012). On the other hand, the adsorption of hydrophobic OM to goethite could become stronger over time at the FC treatment. Likewise, the absence of the OM of Soil 1 could explain the decrease in the goethite percentage at the WL treatment. Indeed, Kim et al., (2010) observed that the iron oxide (goethite, hematite and maghemite) dissolution in ice occurred even in the absence of organic complexing ligands.

Regardless of OM's presence, the Hm-Mh decreased and increased at the FC and WL treatments, respectively. The freeze-thaw cycles decrease and increase the exchangeable Fe under unsaturated and saturated soil conditions, respectively (Roy Chowdhury et al., 2015). Several studies have shown that the OM content is a critical factor in defining soil resilience to the freeze-thaw process (Arthur et al., 2012; Gregory et al., 2009). However, this process (freeze-thaw) could reduce the OM content due to soil organic carbon's mineralisation (Yu et al., 2011). Likewise, laboratory experiments with soils placed at $-15{ }^{\circ} \mathrm{C}$ have shown increased leakage and changes in the quality of dissolved organic carbon (DOC) due to microbial activity (Campbell et al., 
Monitoring the effect of freeze-thaw cycles on soil surface mineralogy using proximal spectroscopy data

2014; Fuss et al., 2016; Haei et al., 2012). Indeed, microbial respiration has been detected at $-40^{\circ} \mathrm{C}$ (Panikov et al., 2006). While the hydrophobic OM (Soil 2 ) could be quickly easily released from hematite in the reduction reaction (Adhikari and Yang, 2015), the hydrophilic compounds (Soil 3) might be affected by $\mathrm{pH}$ (Nam et al., 2014). Therefore under acidic conditions, the Fe might be more hydrolyzed due to freeze-thaw cycles, leading to OM structure alterations affecting the bonding strength.

Many studies have shown that quartz is susceptible to weathering, and its dissolution depends on the concentration of organic ligands, $\mathrm{pH}$, particle size and temperature. The dissolution of quartz increases with increasing temperature (thawing), but it stops when the soil is in the frozen state (Sokolova, 2013). Moreover, the organic molecules react with quartz intensifying the dissolution of the latter. Therefore, the Qz-Gt of Soil 2 and Soil 3 accumulated over time at the FC treatment (Karlsson and Persson, 2010; Sundman et al., 2014). On the other hand, repeated freeze-thaw cycles may trigger the precipitation of quartz for Soil 1 due to the absence of OM (Dietzel, 2005). Moreover, in the saturated soil condition, the disruption of the quartz grains occurred due to repeated freeze-thaw cycles (Schwamborn et al., 2012). As a result, the increase of Qz-Gt of Soil 1 over time could be related to the disruption of quartz at the WL treatment. The decrease of Qz-Gt of Soil 2 and Soil 3 at the WL treatment could be related to the quartz concentration to subsurface due to the cryoturbation process (Hugelius et al., 2010; Struyf et al., 2010).

Freeze-thaw cycles decrease the bonding strength between particles, increase the pore sizes due to the ice formation inside the clay, altering the structure and the properties of the clay (Darbari et al., 2017; Li et al., 2018). Therefore, clay minerals' behaviour depends on the type and the content of clay minerals (e.g., kaolinite), their degree of saturation, the frequency and the magnitude of the freeze-thaw process (Cui et al., 2014; Svensson and Hansen, 2010). Since the clay minerals significantly affect the soil organo-minerals interactions, it is crucial to investigate their behaviour at the freeze-thaw cycles. In this study, the kaolinite effect was not investigated because this clay mineral is detected in the SWIR region of the electromagnetic spectrum.

It is essential to point out that the freeze-thaw process affects the soil more in the vertical direction (depth) than in the horizontal one (surface). Besides the most substantial soil structure variations in the vertical direction, the temperature and pressure gradients also operate in this direction.

Although the ice surface reflectance is affected by the grain size and shape, surface roughness, water and anisotropy presence, these effects (grain size and shape) become important at wavelengths greater than $1000 \mathrm{~nm}$.

The presence of organic and inorganic materials causes a reduction of the spectral reflectance of ice in the visible spectrum. Due to non-ice materials, ice has a low reflectance value of 0.3 and 0.2 in the visible and infrared spectrum, respectively (Di Mauro et al., 2017). In contrast, ice and water absorb light in the infrared range at around $1030 \mathrm{~nm}$ (Dumont et al., 2017). Therefore, it is assumed that the freezing conditions do not affect the determination of the percentage of the minerals in the image.

The SID classifier uses the divergence measure to compare each pixel spectra with the reference spectra. This divergence is directly related to the threshold. 
When the pixel spectra are close to the reference spectra, then the threshold is small. On the contrary, the pixels that have the divergence greater than the specified threshold are not classified. Therefore, to avoid misclassification due to false positive or false negative errors, the threshold should be specific for each mineral occurring in the image. Although the soil aggregates lead to selfshadowing, the SID classifier neglects the spectral information associated with the shadow because it identifies each mineral based on its corresponding spectral signature. Indeed, Chang, (2000) specified that the SID classier is insensitive to the illumination effects and the brightness shifts. Another point to consider is a large number of available spectral bands (169) and the small training samples (8) could have affected the classification accuracy known as the Hughes phenomenon.

\subsection{Conclusions}

In this study, the VNIR spectroscopy data were used to monitor the soil surface mineralogical alterations due to freeze-thaw cycles under laboratory conditions. Three Silty Loam soils varying in the OM content (no, low and high) were chosen. The trays with aggregates were exposed to FC and WL treatments. These treatments were performed because there is limited knowledge of the soil mineralogical behaviour resulting from the freeze-thaw process at different moisture conditions occurring in a short period. The assumption was that using the VNIR spectroscopy data, changes in the soil surface mineralogy due to freeze-thaw cycles at various moisture conditions could be detected and quantified over time. Using the SID approach, the image area occupied by the Mg-clinochlore, goethite, quartz coated $50 \%$ by goethite, hematite dimorphous with maghemite was determined. The results showed that these minerals behaved differently under freeze-thaw cycles, depending on the soil type and soil condition. While the Mg-clinochlore, goethite and QzGt behaviour relies on OM's presence, the $\mathrm{Hm}-\mathrm{Mh}$ showed not such a dependence. Likewise, the results suggest that the amount and the type of OM are vital in soil experiencing the freeze-thaw cycles. Also, when the soil is exposed to the freeze-thaw cycles, the moisture conditions (FC or WL) significantly impact mineral behaviour regardless of the soil type. Using imaging spectroscopy data on the Silty Loam soil, it is showed that the surface mineralogy changes over time due to freeze-thaw cycles, depending on the soil type and the moisture conditions. The freeze-thaw process alters the soil mineralogical composition, which might affect the soil aggregate stability. I ron hydroxides can interact with both the clay minerals and organic compounds to form clay-mineral-organic associations, acting as binding and cementing agents in the soil. The interactions between the mineral particles and the OM in soil depend on the concentration of the cations. However, the freeze-thaw process causes the cations' release and precipitation promoting the disaggregation and breakdown of the soil aggregates. 
Monitoring the effect of freeze-thaw cycles on soil surface mineralogy using proximal spectroscopy data

\subsection{References}

Adhikari, D., Yang, Y., 2015. Selective stabilization of aliphatic organic carbon by iron oxide. Scientific Reports. 5(1), 11214.

Angin, I., Aksakal, E.L., Oztas, T., Hanay, A., 2013. Effects of municipal solid waste compost (MSWC) application on certain physical properties of soils subjected to freeze-thaw. Soil and Tillage Research. 130, 58-61.

Arthur, E., Schjonning, P., Moldrup, P., de Jonge, L.W., 2012. Soil resistance and resilience to mechanical stresses for three differently managed sandy loam soils. Geoderma. 173, 50-60.

Bajracharya, R.M., Lal, R., Hall, G.F., 1998. Temporal variation in properties of an uncropped, ploughed Miamian soil in relation to seasonal erodibility. Hydrological Processes. 12(7), 1021-1030.

Blackwell, M.S.A., Brookes, P.C., de la Fuente-Martinez, N., Gordon, H., Murray, P.J., Snars, K.E., Williams, J.K., Bol, R., Haygarth, P.M., 2010. Chapter 1 - Phosphorus Solubilization and Potential Transfer to Surface Waters from the Soil Microbial Biomass Following Drying-Rewetting and Freezing-Thawing. Advances in Agronomy. D. L. Sparks, Academic Press. 106, 1-35.

Butz, C., Grosjean, M., Fischer, D., Wunderle, S., Tylmann, W., Rein, B. 2015. Hyperspectral imaging spectroscopy: a promising method for the biogeochemical analysis of lake sediments. J ournal of Applied Remote Sensing. 9.

Campbell, J.L., Reinmann, A.B., Templer, P.H., 2014. Soil Freezing Effects on Sources of Nitrogen and Carbon Leached During Snowmelt. Soil Science Society of America J ournal. 78(1), 297-308.

Chai, Y.J., Zeng, X.B.E.S. Z., Bai, L.Y., Su, S.M., Huang, T., 2014. Effects of freeze-thaw on aggregate stability and the organic carbon and nitrogen enrichment ratios in aggregate fractions. Soil Use and Management. 30(4), 507-516.

Chang, C.I., 2000. An information-theoretic approach to spectral variability, similarity, and discrimination for hyperspectral image analysis. leee Transactions on Information Theory. 46(5), 1927-1932.

Cui, Z.D., He, P.P., Yang, W.H., 2014. Mechanical properties of a silty clay subjected to freezing-thawing. Cold Regions Science and Technology. 98, 2634.

Dagesse, D.F., 2013. Freezing cycle effects on water stability of soil aggregates. Canadian J ournal of Soil Science. 93(4), 473-483.

Dang, X., Zhang, Y., Yu, N., Zhang, Y., 2012. Cadmium adsorption-desorption of brown soil with freeze-thaw cycles in northeast China. International J ournal of Environment and Pollution. 49(1-2), 89-99.

Darbari, Z., Jaradat, K.A., Abdelaziz, S.L., 2017. Heating-freezing effects on the pore size distribution of a kaolinite clay. Environmental Earth Sciences. 76(20), 713.

Di Mauro, B., Baccolo, G., Garzonio, R., Giardino, C., Massabo, D., Piazzalunga, A., Rossini, M., Colombo, R., 2017. I mpact of impurities and cryoconite on the optical properties of the Morteratsch Glacier (Swiss Alps). Cryosphere. 11(6), 2393-2409. 
Dietzel, M., 2005. Impact of cyclic freezing on precipitation of silica in Me$\mathrm{SiO} 2-\mathrm{H} 2 \mathrm{O}$ systems and geochemical implications for cryosoils and -sediments. Chemical Geology. 216(1), 79-88.

Dumont, M., Arnaud, L., Picard, G., Libois, Q., Lejeune, Y., Nabat, P., Voisin, D., Morin, S., 2017. In situ continuous visible and near-infrared spectroscopy of an alpine snowpack. Cryosphere 11(3), 1091-1110.

Emerson, D., Scott, J. J., Benes, J., Bowden, W.B., 2015. Microbial Iron Oxidation in the Arctic Tundra and Its I mplications for Biogeochemical Cycling. Applied and Environmental Microbiology. 81(23), 8066-8075.

ENVI., 2015. Exelis Visual Information Solutions. from http://www. harrisgeospatial.com/.

Ferrick, M.G., Gatto, L.W., 2005. Quantifying the effect of a freeze-thaw cycle on soil erosion: laboratory experiments. Earth Surface Processes and Landforms. 30(10), 1305-1326.

Freppaz, M., Williams, B. L., Edwards, A. C., Scalenghe, R., Zanini, E., 2007. Labile nitrogen, carbon, and phosphorus pools and nitrogen mineralization and immobilization rates at low temperatures in seasonally snow-covered soils. Biology and Fertility of Soils. 43(5), 519-529.

Fuss, C.B., Driscoll, C.T., Groffman, P.M., Campbell, J.L., Christenson, L.M., Fahey, T.J., Fisk, M.C., Mitchell, M.J., Templer, P.H., Durán, J., Morse, J.L. 2016. Nitrate and dissolved organic carbon mobilization in response to soil freezing variability. Biogeochemistry. 131(1), 35-47.

Gregory, A.S., Watts, C.W., Griffiths, B.S., Hallett, P.D., Kuan, H.L., Whitmore, A.P., 2009. The effect of long-term soil management on the physical and biological resilience of a range of arable and grassland soils in England. Geoderma. 153(1-2), 172-185.

Haei, M., Öquist, M. G., Ilstedt, U., Laudon, H., 2012. The influence of soil frost on the quality of dissolved organic carbon in a boreal forest soil: combining field and laboratory experiments. Biogeochemistry. 107(1), 95-106.

Hanesch, M., Stanjek, H., Petersen, N., 2006. Thermomagnetic measurements of soil iron minerals: the role of organic carbon. Geophysical Journal International. 165(1), 53-61.

Heckman, K., Welty-Bernard, A., Vazquez-Ortega, A., Schwartz, E., Chorover, J., Rasmussen, C., 2013. The influence of goethite and gibbsite on soluble nutrient dynamics and microbial community composition. Biogeochemistry. 112(1), 179-195.

Herndon, E.M., Yang, Z., Bargar, J., Janot, N., Regier, T.Z., Graham, D.E., Wullschleger, S.D., Gu, B., Liang, L., 2015. Geochemical drivers of organic matter decomposition in arctic tundra soils. Biogeochemistry. 126(3), 397414.

Hinman, W.C., 1970. Effects of freezing and thawing on some chemicalproperties of 3 soils. Canadian J ournal of Soil Science. 50(2), 179-\&. Hugelius, G., Kuhry, P., Tarnocai, C., Virtanen, T., 2010. Soil Organic Carbon Pools in a Periglacial Landscape: a Case Study from the Central Canadian Arctic. Permafrost and Periglacial Processes. 21(1), 16-29.

Jabro, J.D., Iversen, W.M., Evans, R.G., Allen, B.L., Stevens, W.B., 2014. Repeated Freeze-Thaw Cycle Effects on Soil Compaction in a Clay Loam in Northeastern Montana. Soil Science Society of America Journal. 78(3), 737744. 
Monitoring the effect of freeze-thaw cycles on soil surface mineralogy using proximal spectroscopy data

Jelenek, J., Kopackova, V., Koucka, L., Misurec, J., 2016. Testing a Modified PCA-Based Sharpening Approach for Image Fusion. Remote Sensing. 8(10), 25.

Jeong, D., Kim, K., Choi, W., 2012. Accelerated dissolution of iron oxides in ice. Atmospheric Chemistry and Physics. 12(22), 11125-11133.

Kaiser, K., Kalbitz, K., 2012. Cycling downwards - dissolved organic matter in soils. Soil Biology \& Biochemistry. 52, 29-32.

Karlsson, T., Persson, P., 2010. Coordination chemistry and hydrolysis of $\mathrm{Fe}(\mathrm{III})$ in a peat humic acid studied by X-ray absorption spectroscopy. Geochimica et Cosmochimica Acta. 74(1), 30-40.

Kim, E.A., Choi, J.H., 2018. Changes in the mineral element compositions of soil colloidal matter caused by a controlled freeze-thaw event. Geoderma. 318, 160- 166.

Kim, K., Choi, W., Hoffmann, M.R., Yoon, H.I., Park, B.K., 2010. Photoreductive Dissolution of I ron Oxides Trapped in Ice and Its Environmental Implications. Environmental Science \& Technology. 44(11), 4142-4148.

Kim, K., Menacherry, S.P.M., Kim, J., Chung, H.Y., Jeong, D., Saiz-Lopez, A., Choi, W., 2019. Simultaneous and Synergic Production of Bioavailable Iron and Reactive Iodine Species in Ice. Environmental Science \& Technology. 53(13), 7355-7362.

Kim, M.J., 2014. A study on the adsorption characteristics of cadmium and zinc onto acidic and alkaline soils. Environmental Earth Sciences. 72(10), 39813990.

Kou, X., Jiang, L., Yan, S., Zhao, T., Lu, H., Cui, H., 2017. Detection of land surface freeze-thaw status on the Tibetan Plateau using passive microwave and thermal infrared remote sensing data. Remote Sensing of Environment. 199, 291-301.

Kuo, M.H., Moussa, S.G., McNeill, V.F., 2011. Modeling interfacial liquid layers on environmental ices. Atmospheric Chemistry and Physics. 11(18), 99719982.

Lee, H., Schuur, E.A.G., Inglett, K.S., Lavoie, M., Chanton, J.P., 2012. The rate of permafrost carbon release under aerobic and anaerobic conditions and its potential effects on climate. Global Change Biology. 18(2), 515-527.

Li, G.Y., Fan, H.M., (2014). Effect of Freeze-Thaw on Water Stability of Aggregates in a Black Soil of Northeast China. Pedosphere. 24(2), 285-290.

Li, G., Wang, F., Ma, W., Fortier, R., Mu, Y., Mao, Y., Hou, X. 2018. Variations in strength and deformation of compacted loess exposed to wetting-drying and freeze-thaw cycles. Cold Regions Science and Technology. 151, 159-167.

Li, L., Ma, J., Xu, M., Li, X., Tao, J., Wang, G., Yu, J., Guo, P., 2016. The Adsorption and Desorption of $\mathrm{Pb} 2+$ and $\mathrm{Cd} 2+$ in Freeze-Thaw Treated Soils. Bulletin of Environmental Contamination and Toxicology. 96(1), 107-112.

Li, Z., Geng, Z., Li, P., Xiao, L., Liu, Y., 2019. Soil organic matter and glomalinrelated soil protein contents do not explain soil aggregate stability after freezethaw cycles at contrasting soil moisture contents. Archives of Agronomy and Soil Science.

Liu, H.B., Chen, T.H., Zou, X.H., Qing, C.S., Frost, R.L., 2013. Thermal treatment of natural goethite: Thermal transformation and physical properties. Thermochimica Acta. 568, 115-121.

Mariotto, I., Thenkabail, P.S., Huete, A., Slonecker, E.T., Platonov, A., 2013. Hyperspectral versus multispectral crop-productivity modeling and type 
discrimination for the HysplRI mission. Remote Sensing of Environment. 139(Supplement C), 291-305.

Mohamed, A.M.O., Shooshpasha, I., Yong, R.N., 1996. Boundary layer transport of metal ions in frozen soil. International Journal for Numerical and Analytical Methods in Geomechanics. 20(10), 693-713.

Mohanty, S.K., Saiers, J.E., Ryan, J.N., 2014. Colloid-Facilitated Mobilization of Metals by Freeze-Thaw Cycles. Environmental Science \& Technology. 48(2), 977-984.

Naegeli, K., Damm, A., Huss, M., Schaepman, M., Hoelzle, M., 2015. Imaging spectroscopy to assess the composition of ice surface materials and their impact on glacier mass balance. Remote Sensing of Environment. 168, 388402.

Nam, S.W., Choi, D.J., Kim, S.K., Her, N., Zoh, K.D., 2014. Adsorption characteristics of selected hydrophilic and hydrophobic micropollutants in water using activated carbon. Journal of Hazardous Materials. 270, 144-152.

Nguyen, H.T., Lee, B.W., 2006. Assessment of rice leaf growth and nitrogen status by hyperspectral canopy reflectance and partial least square regression. European J ournal of Agronomy. 24(4), 349-356.

Oztas, T., Fayetorbay, F., 2003. Effect of freezing and thawing processes on soil aggregate stability. Catena. 52(1), 1-8.

Panikov, N.S., Flanagan, P.W., Oechel, W.C., Mastepanov, M.A., Christensen, T.R., 2006. Microbial activity in soils frozen to below $-39^{\circ} \mathrm{C}$. Soil Biology and Biochemistry. 38(4), 785-794

Paré, T., Dinel, H., Moulin, A.P., Townley-Smith, L., 1999. Organic matter quality and structural stability of a Black Chernozemic soil under different manure and tillage practices. Geoderma. 91(3), 311-326.

Pokrovsky, O.S., Karlsson, J., Giesler, R., 2018. Freeze-thaw cycles of Arctic thaw ponds remove colloidal metals and generate low-molecular-weight organic matter. Biogeochemistry. 137(3), 321-336.

Qin, J., Burks, T.F., Ritenour, M.A., Bonn, W.G., 2009. Detection of citrus canker using hyperspectral reflectance imaging with spectral information divergence. Journal of Food Engineering. 93(2), 183-191.

Rautiainen, K., Parkkinen, T., Lemmetyinen, J., Schwank, M., Wiesmann, A., Ikonen, J., Derksen, C., Davydov, S., Davydova, A., Boike, J., Langer, M., Drusch, M., Pulliainen, J., 2016. SMOS prototype algorithm for detecting autumn soil freezing. Remote Sensing of Environment. 180, 346-360.

Richards, J., 1993. Remote Sensing Digital Image Analysis, An Introduction. Springer-Verlag.

Rivkina, E.M., Friedmann, E.I., McKay, C.P., Gilichinsky, D.A., 2000. Metabolic activity of permafrost bacteria below the freezing point. Applied and Environmental Microbiology. 66(8), 3230-3233.

Rowlandson, T.L., Berg, A.A., Roy, A., Kim, E., Pardo Lara, R., Powers, J., Lewis, K., Houser, P., McDonald, K., Toose, P., Wu, A., De Marco, E., Derksen, C., Entin, J., Colliander, A., Xu, X., Mavrovic, A., 2018. Capturing agricultural soil freeze/thaw state through remote sensing and ground observations: A soil freeze/thaw validation campaign. Remote Sensing of Environment. 211, 5970.

Roy, A., Royer, A., Derksen, C., Brucker, L., Langlois, A., Mialon, A.Kerr, Y.H. 2015. Evaluation of Spaceborne L-Band Radiometer Measurements for Terrestrial Freeze/Thaw Retrievals in Canada. I eee J ournal of Selected Topics in Applied Earth Observations and Remote Sensing. 8(9), 4442-4459. 
Monitoring the effect of freeze-thaw cycles on soil surface mineralogy using proximal spectroscopy data

Roy Chowdhury, T., Herndon, E.M., Phelps, T.J., Elias, D.A., Gu, B., Liang, L., Wullschleger, S.D., Graham, D.E., 2015. Stoichiometry and temperature sensitivity of methanogenesis and $\mathrm{CO} 2$ production from saturated polygonal tundra in Barrow, Alaska. Global Change Biology. 21(2), 722-737.

Sahin, U., Angin, I., Kiziloglu, F.M., 2008. Effect of freezing and thawing processes on some physical properties of saline-sodic soils mixed with sewage sludge or fly ash. Soil and Tillage Research. 99(2), 254-260.

Schwamborn, G., Schirrmeister, L., Frütsch, F., Diekmann, B. 2012. Quartz weathering in freeze-thaw cycles: experiment and application to the el'gygytgyn crater lake record for tracing siberian permafrost history. Geografiska Annaler: Series A, Physical Geography. 94(4), 481-499.

Shafique, U., Anwar, J., Munawar, M.A., Zaman, W.U., Rehman, R., Dar, A., Salman, M., Saleem, M., Shahid, N., Akram, M., Naseer, A., Jamil, N., 2016. Chemistry of ice: Migration of ions and gases by directional freezing of water. Arabian Journal of Chemistry. 9, S47-S53.

Sokolova, T.A., 2013. The destruction of quartz, amorphous silica minerals, and feldspars in model experiments and in soils: Possible mechanisms, rates, and diagnostics (the analysis of literature). Eurasian Soil Science. 46(1), 91105.

Song, Y., Zou, Y., Wang, G., Yu, X., 2017. Stimulation of nitrogen turnover due to nutrients release from aggregates affected by freeze-thaw in wetland soils. Physics and Chemistry of the Earth, Parts A/B/C. 97, 3-11.

Stahli, M., Stadler, D., 1997. Measurement of water and solute dynamics in freezing soil columns with time domain reflectometry. Journal of Hydrology. 195(1-4), 352-369.

Starkloff, T., Larsbo, M., Stolte, J., Hessel, R., Ritsema, C., 2017. Quantifying the impact of a succession of freezing-thawing cycles on the pore network of a silty clay loam and a loamy sand topsoil using X-ray tomography. Catena. 156, 365-374.

Struyf, E., Morth, C.M., Humborg, C., Conley, D.J., 2010. An enormous amorphous silica stock in boreal wetlands. Journal of Geophysical ResearchBiogeosciences. 115.

Sundman, A., Karlsson, T., Laudon, H., Persson, P., 2014. XAS study of iron speciation in soils and waters from a boreal catchment. Chemical Geology. 364, 93-102.

Svensson, P.D., Hansen, S., 2010. Freezing and thawing of montmorillonite A time-resolved synchrotron X-ray diffraction study. Applied Clay Science. 49(3), 127-134.

Takenaka, N., Ueda, A., Daimon, T., Bandow, H., Dohmaru, T., Maeda, Y., 1996. Acceleration Mechanism of Chemical Reaction by Freezing: The Reaction of Nitrous Acid with Dissolved Oxygen. The Journal of Physical Chemistry. 100(32), 13874-13884.

Tang, J., Liang, S., Li, Z., Zhang, H., Lou, Y., Wang, J., 2016. Effect of freezethaw cycles on carbon stocks of saline-alkali paddy soil. Archives of Agronomy and Soil Science. 62(12), 1640-1653.

Torrance, J.K., Elliot, T., Martin, R., Heck, R.J., 2008. X-ray computed tomography of frozen soil. Cold Regions Science and Technology. 53(1), 7582.

USGS., 2017. Digital Spectral Library. Retrieved (accessed 4 September 2017), from https://crustal.usgs.gov. 
van der Meer, F., 2006. The effectiveness of spectral similarity measures for the analysis of hyperspectral imagery. International Journal of Applied Earth Observation and Geoinformation. 8(1), 3-17.

Van der Meer, F., J ia, X., 2012. Collinearity and orthogonality of endmembers in linear spectral unmixing. International J ournal of Applied Earth Observation and Geoinformation. 18, 491-503.

Veer, G.v.d., 2006. Geochemical soil survey of the Netherlands. PhD thesis. Utrecht University. The Netherlands.

Wang, J.F., Wu, Q.B., 2013. Impact of experimental warming on soil temperature and moisture of the shallow active layer of wet meadows on the Qinghai-Tibet Plateau. Cold Regions Science and Technology. 90-91, 1-8.

Xu, M.M., Zhang, L.P., Du, B., 2015. An Image-Based Endmember Bundle Extraction Algorithm Using Both Spatial and Spectral I nformation. I eee J ournal of Selected Topics in Applied Earth Observations and Remote Sensing. 8(6), 2607-2617.

Ymeti, I., Pikha Shrestha, D., van der Meer, F., 2019. Monitoring Soil Surface Mineralogy at Different Moisture Conditions Using Visible Near-Infrared Spectroscopy Data. Remote Sensing. 11(21), 2526.

Ymeti, I., van der Werff, H., Shrestha, D. P., J etten, V. G., Lievens, C., van der Meer, F., 2017. Using Color, Texture and Object-Based I mage Analysis of MultiTemporal Camera Data to Monitor Soil Aggregate Breakdown. Sensors. 17(6). Yu, X., Zou, Y., Jiang, M., Lu, X., Wang, G., 2011. Response of soil constituents to freeze-thaw cycles in wetland soil solution. Soil Biology and Biochemistry. 43(6), 1308-1320.

Zavala, L.M., Granged, A.J.P., J ordán, A., Bárcenas-Moreno, G., 2010. Effect of burning temperature on water repellency and aggregate stability in forest soils under laboratory conditions. Geoderma. 158(3), 366-374.

Zhang, Z., Ma, W., Feng, W., Xiao, D., Hou, X., 2016. Reconstruction of Soil Particle Composition During Freeze-Thaw Cycling: A Review. Pedosphere. 26(2), 167-179.

Zhao, H.Q., Zhao, X.S., Cen, Y., Yang, H., 2017. Research on the Impact of Absorption Feature Extraction on Spectral Difference Between Similar Minerals. Spectroscopy and Spectral Analysis. 37(3), 869-874.

Zhao, T.J., Shi, J.C., Hu, T.X., Zhao, L., Zou, D.F., Wang, T.X., Ji, D.B., Li, R., Wang, P.K. 2017. Estimation of high-resolution near-surface freeze/thaw state by the integration of microwave and thermal infrared remote sensing data on the Tibetan Plateau. Earth and Space Science. 4(8), 472-484. 
Monitoring the effect of freeze-thaw cycles on soil surface mineralogy using proximal spectroscopy data 


\section{Using Color, Texture and Object-Based Image Analysis of Multi-Temporal Camera} Data to Monitor Soil Aggregate Breakdown*

*This chapter is based on: Ymeti, I.; van der Werff, H.; Shrestha, D.P.; Jetten, V.G.; Lievens, C.; van der Meer, F. Using Color, Texture and Object-Based Image Analysis of Multi-Temporal Camera Data to Monitor Soil Aggregate Breakdown. Sensors 2017, 17, 1241 
Using Color, Texture and Object-Based I mage Analysis of Multi-Temporal Camera Data to Monitor Soil Aggregate Breakdown

\section{Abstract}

Remote sensing has shown its potential to assess soil properties and is a fast and non-destructive method for monitoring soil surface changes. In this paper, soil aggregate breakdown under natural conditions was monitored. From November 2014 to February 2015, images and weather data were collected daily from five soils susceptible to detachment (Silty Loam with various organic matter content, Loam and Sandy Loam). Three techniques that vary in image processing complexity and user interaction were tested for the ability of monitoring aggregate breakdown. Considering that the soil surface roughness causes shadow cast, the blue/red band ratio is utilized to observe the soil aggregate changes. Dealing with images with high spatial resolution, image texture entropy, which reflects the process of soil aggregate breakdown, is used. Also, the Huang thresholding technique, which allows estimation of the image area occupied by soil aggregate, is performed. The results show that all three techniques indicate soil aggregate breakdown over time. The shadow ratio shows a gradual change over time, with no details related to weather conditions. Both the entropy and the Huang thresholding technique show variations of soil aggregate breakdown responding to weather conditions. Using data obtained with a regular camera, it is found that freeze-thaw cycles are the cause of soil aggregate breakdown.

\subsection{Introduction}

Soil aggregate breakdown is a function of soil strength and the kinetic energy of the rainfall (Cruse and Larson, 1977; Shainberg et al., 1992). Soil strength depends on soil particle distribution, structure, soil organic carbon, ionic bridging, clay and carbonates. Different land cover or land use, such as forest or agriculture, influences soil structure and organic matter content (Shrestha et al., 2014). Other properties may relate to climate (e.g., high calcium carbonate content in the drier environment) or soil processes (e.g., high iron oxide content in Ultisols or Oxisols). Aggregate stability also decreases when water-dispersible clay content increases with total clay, as reported in (Shrestha et al., 2004). Weather conditions influence soil aggregate, especially when both rainfall and freeze-thaw cycles occur (Mulla et al., 1992). While rainfall induces soil aggregate breakdown, compaction and crusting, freezethaw cycles mainly affect the formation and destruction of soil structure (Bajracharya et al., 1998; Kværnø and Øygarden, 2006). During a rainfall event, soil macro-aggregate $(>250 \mu \mathrm{m})$ breaks down into smaller aggregate (Legout et al., 2005; Plante et al., 2002; Puget et al., 2000).

Rainfall can destroy soil aggregate via two processes: (i) the direct impacts of water drops mechanically disintegrate aggregate into smaller particles leading to surface sealing; and (ii) the small aggregates are submerged rapidly during rainfall, the air is trapped, and aggregates implode (Agassi et al., 1981). While a structural crust is formed when aggregates are reorganized with limited particle displacement, a sedimentary crust results from clay particle displacement (Cerdan et al., 2002). Both mechanisms help to create a thin crust layer with a light colour, high bulk density and low porosity (Ben-Dor et 
al., 2003; de Jong, 1992; Eshel et al., 2004). Soil detachment by raindrops is the start of interrill erosion and surface seal formation. Detecting and monitoring soil aggregate breakdown requires a micro-plot scale having an area of some hundreds of square centimetres. It is already known that groundbased methods are time-consuming and expensive.

Remote Sensing (RS) has shown potential to assess several soil properties such as moisture, organic matter, iron, sand and clay (Ben-Dor et al., 1997; BenDor et al., 2002; Farrand and Harsanyi, 1997; Salisbury and D'Aria, 1992; Stoner and Baumgardner, 1981). Microwave RS has been used to determine soil moisture and soil surface roughness (Collingwood et al., 2014; Kornelsen and Coulibaly, 2013; Seung-Bum et al., 2012). Optical photogrammetry is utilized to represent the soil surface roughness as the standard deviation of elevation data (Gessesse et al., 2010; Ouédraogo et al., 2014; Taconet and Ciarletti, 2007). There are RS studies that have investigated the effect of natural rainfall on surface roughness. Calculating surface roughness indices such as standard deviation of height (vertical component) and autocorrelation length (a horizontal component of roughness spectra) from Digital Surface Models (DSM) obtained from a ploughed and harrowed field, Marzahn et al., (2012) reported a decline in roughness due to rainfall. Recently, the Structure from Motion ( $\mathrm{SfM}$ ) approach is used to calculate the roughness parameters on a $2 \times 3.4 \mathrm{~m}^{2}$ plot over three months based on the Fourier transform of the digital elevation model (DEM). This research concluded that roughness changes, due to weather conditions, happened at a spatial resolution below 50 $\mathrm{cm}$ (Snapir et al., 2014). To quantify changes in soil surface structure associated with the macro-aggregate breakdown, Croft et al., (2009) combined laser scanner and hyperspectral data measured at a variety of viewing and illumination solar angles. They found that, due to crusting, the surface roughness declines, and the effect of shadow-casting by soil aggregate reduces. Also, Moreno et al., (2011) concluded that shadow analysis is a suitable technique to assess the soil surface roughness decline of a sandy clay loam soil after tillage operation.

Using RS approach changes on soil aggregate breakdown occurring over a short time can be detected. Therefore, understanding and monitoring the interaction between the soil surface and the surrounding environment at a high temporal resolution is crucial. Also, data acquisition remains expensive, and image analysis is often complicated and time-consuming. Therefore, this study investigated the possibility to monitor soil aggregate breakdown straightforwardly and cost-effectively. A red, green, blue (RGB) Single-lens reflex (SLR) camera mounted in a fixed setup was used to enable photographing the same location over time acquiring time-series data acquisition. Next, the capability of the RGB SLR camera to monitor soil aggregate breakdown in soils of different texture classes under natural conditions on a micro-plot scale daily was examined. 
Using Color, Texture and Object-Based I mage Analysis of Multi-Temporal Camera Data to Monitor Soil Aggregate Breakdown

\subsection{Materials and methods}

\subsubsection{Experimental setup}

An outdoor experiment consisted of an RGB SLR camera and a weather station both mounted on a tripod was designed to monitor aggregate breakdown under natural conditions. Also, below the tripod, five trays filled with soil were placed. The soil samples were collected at the end of September 2014 in Limburg (Silty Loam with various amount of organic matter content (OM) and Loam) and Deventer (Sandy Loam), both in The Netherlands. Soil aggregate stability was performed on soils according to ISO 10930 (Le Bissonnais, 1996), to provide a realistic analysis of the structural stability of soil aggregates when subjected to the action of weather, cultivation, and to enable the soils to be classified based on the stability of their aggregates. The results obtained showed that the Soil 1 (Silty Loam) was very unstable while the rest of the soils were unstable. In order to see the effect of land use/land cover on soil aggregate stability samples were collected from topsoil $(20 \mathrm{~cm})$ of agricultural fields as well as forest area. The soil particle size determination was carried out on fine earth $(<2 \mathrm{~mm}$ ) according to the ISRIC protocol (van Reeuwijk, 2002). While the $\mathrm{OM}$ was oxidized with $\mathrm{H}_{2} \mathrm{O}_{2}$, the sand was separated from clay and silt with a $50 \mu \mathrm{m}$ sieve. The clay and silt fractions were determined with the pipette method based on sampling a 1-litre suspension with a $20 \mathrm{ml}$ pipette. The obtained clay, silt and sand fraction are calculated on a dry-ash-free basis. The $\mathrm{OM}$ was determined by heating the sample at $600{ }^{\circ} \mathrm{C}$ for more than $12 \mathrm{~h}$ and calculating the weight loss on the dry soil. Table 5-1 summarizes soil characteristics used in this study.

Table 5-1. The soils used in this study. Soils 1-4 (Silty Loam and Loam) were sampled in the Limburg province, the Netherlands, and Soil 5 (Sandy Loam) was sampled in the city of Deventer, the Netherlands. The agricultural crop cultivated on all the fields was maize. However, at the time of soil sampling, this crop was already harvested.

\begin{tabular}{lllllllll}
\hline Soil ID & Location (WGS 84) & \multicolumn{3}{c}{$\begin{array}{c}\text { Soil Particle Size } \\
(\%)\end{array}$} & $\begin{array}{c}\text { Texture } \\
\text { Class }\end{array}$ & $\begin{array}{l}\text { OM } \\
(\%)\end{array}$ & Land Use \\
\cline { 2 - 6 } & Lat & Long & Clay & Silt & Sand & & \\
\hline Soil 1 & $50.7758^{\circ}$ & $5.8824^{\circ}$ & 16 & 71 & 13 & Silty Loam & 4.6 & Agriculture \\
Soil 2 & $50.7687^{\circ}$ & $5.9201^{\circ}$ & 23 & 52 & 25 & Silty Loam & 12.3 & Agriculture \\
Soil 3 & $50.7727^{\circ}$ & $5.9213^{\circ}$ & 22 & 54 & 24 & Silty Loam & 12.5 & Forest \\
Soil 4 & $50.8694^{\circ}$ & $5.7884^{\circ}$ & 17 & 44 & 39 & Loam & 5.6 & Agriculture \\
Soil 5 & $52.2810^{\circ}$ & $6.1813^{\circ}$ & 14 & 11 & 75 & Sandy loam & 5.3 & Agriculture \\
\hline
\end{tabular}

The soil samples were air-dried at room condition for four weeks. Five trays of $60 \times 40 \times 5.5 \mathrm{~cm}^{3}$ were filled manually with soil using a small shovel. Soil aggregates of various sizes were randomly distributed because of this procedure. Moreover, the trays were tilted at an angle of approximately 10 degrees to allow the trays to drain. Drainage was enabled by $5 \mathrm{~mm}$ diameter holes drilled in one side of the tray at the bottom. Likewise, pantyhose filters were used to avoid soil leaking out. Together with the camera, a DAVIS Instruments ISO 9001(DAVIS, 2010) weather station was installed $2 \mathrm{~m}$ above ground to record rainfall and air temperature data at a thirty minutes interval. 
Five trays $\left(60 \times 40 \times 5.5 \mathrm{~cm}^{3}\right)$ filled with the soil of different texture and OM content were photographed each day at 15:00, as shown in Figure 5-1. These bare soils were kept undisturbed for photographing. Images were collected from November 2014 to February 2015.

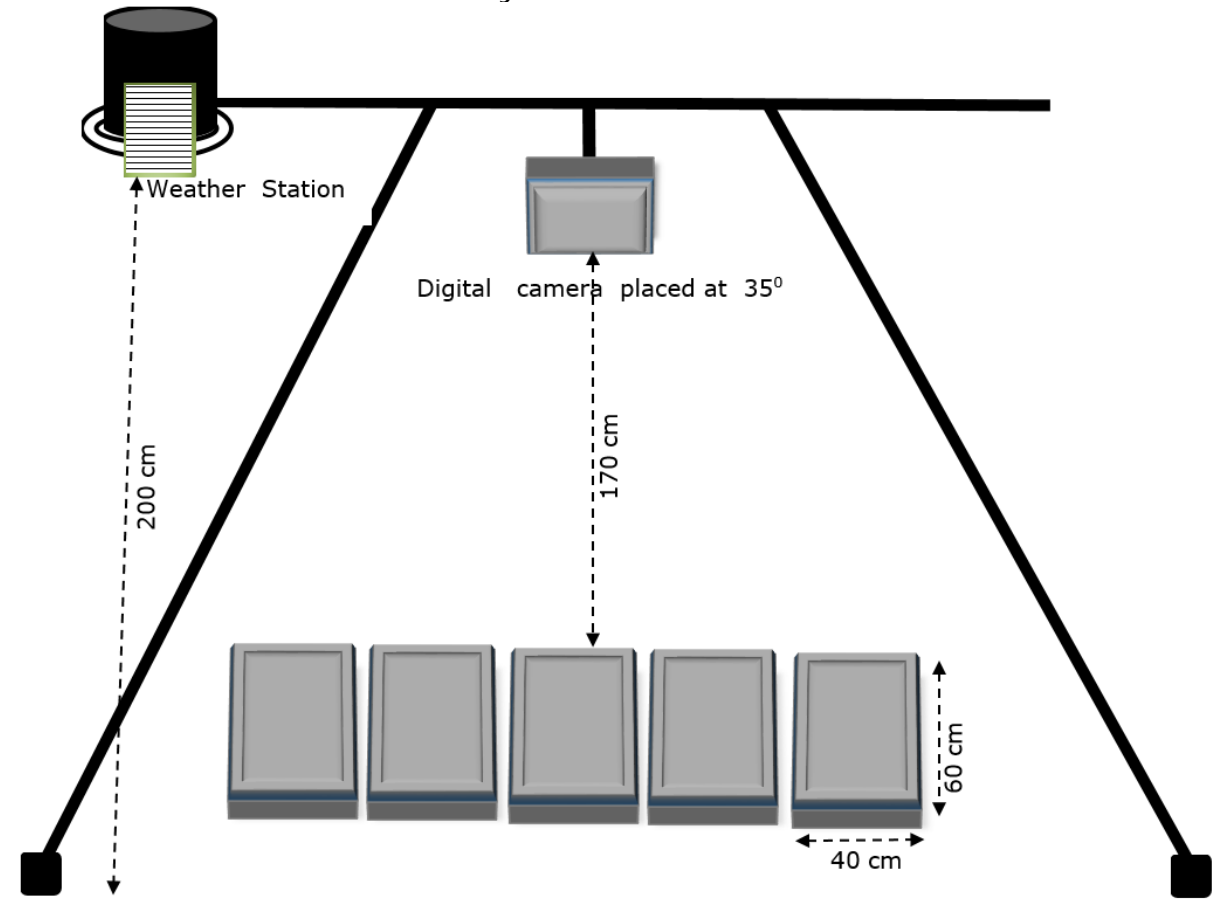

Figure 5-1. Schematic design of the outdoor experimental setup. On the tripod are both the weather station (on the left) and the camera (in the centre) placed at an angle of $35^{\circ}$. Next to the tripod are the undisturbed soil trays photographed each day. From left to right, the Silty Loam with low OM content, Silty Loam with high OM content, Loam and Sandy Loam is placed.

\subsubsection{Image acquisition}

A Canon EOS 600 time-lapse camera housing was mounted on a tripod above the trays, to monitor soil aggregate breakdown. The camera had a $60^{\circ}$ and $43^{\circ}$ horizontal and vertical field of view, respectively. The camera was placed with an angle of approximating $35^{\circ}$, making an oblique capture of the trays to avoid influencing the rain. The camera took photos each day, at 15:00 local time with a solar elevation varied between $13.6^{\circ}$ and $17.5^{\circ}$ (with the lowest solar elevation of $7.5^{\circ}$ on 16 December) while the azimuth changed from $220.6^{\circ}$ to $213.9^{\circ}$ on 4 November 2014 and on 10 February 2015, respectively. Calibration panels were present in the field of view. The panels however often were saturated in the image and also appeared to darken with moist. The camera had a 14-bit A/D converter delivering 8-bit (RGB) data. With this dynamic range, there was not a single set of camera settings that could answer 
Using Color, Texture and Object-Based I mage Analysis of Multi-Temporal Camera Data to Monitor Soil Aggregate Breakdown

to all illumination conditions. A histogram-matching of the data was hence performed when needed in the subsequent time-series analysis (see below in Section 5.2.5). Given the approximated three months duration of the experiment, the solar elevation and azimuth change was $3.9^{\circ}$ and $6.7^{0}$, respectively. A further correction for this change, as well as BRDF differences between the trays, was therefore not implemented. The images were subset to the middle of the tray to avoid seeing the edge, as shown in Figure 5-2. Image software provides a tool which converts an image from pixels to any metric units. Knowing the distance in pixel and the real distance (e.g., in millimetres) of the image, the spatial resolution of this image can be calculated. The images of $512 \times 512$ pixels correspond to a $288 \times 288 \mathrm{~mm}$ area with a spatial resolution of $1.8 \mathrm{~mm} /$ pixels.

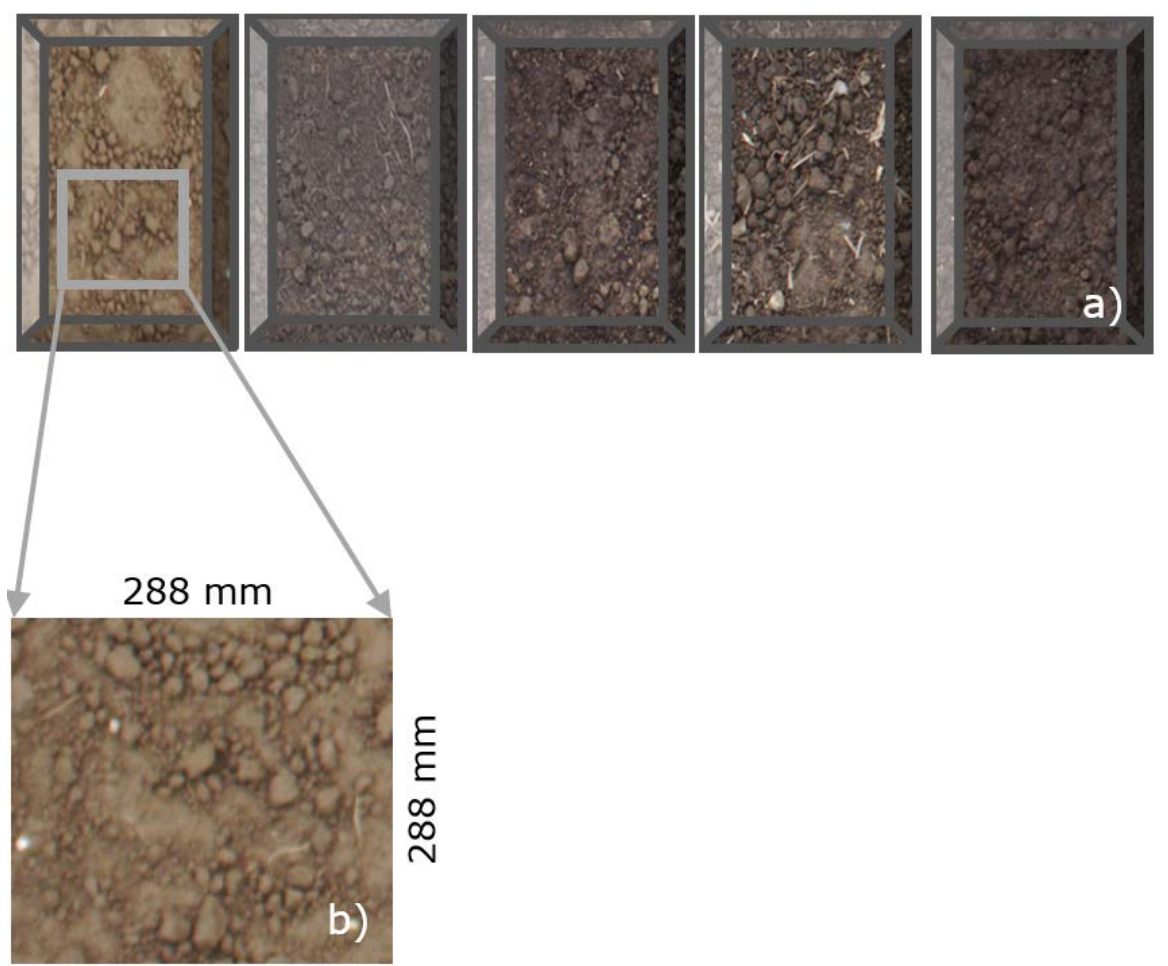

Figure 5-2. Example of an image selected for analysis: the soil trays photographed on 15 November 2014 (a); and one of the five $288 \times 288 \mathrm{~mm}$ image subset with a pixel size $1.8 \mathrm{~mm}$ (b).

Images that could not be used for analysis because of snow cover, fog or standing water, were discarded after visual inspection. Additionally, the basic statistics such as minimum, maximum, mean and standard deviation were calculated for each image. These statistics were performed considering the three bands (red, green and blue). I mages influenced by direct sunlight or a frozen soil surface had a higher standard deviation (digital number) value compared to an accepted image for further analysis (Figure 5-3f). Therefore, 
the images with a standard deviation higher than 15 for Soil 1 and Soil 4, 10 for Soil 2 and Soil 5 and 13 for Soil 3 were discarded (Figure 5-3). These thresholds were derived experimentally.
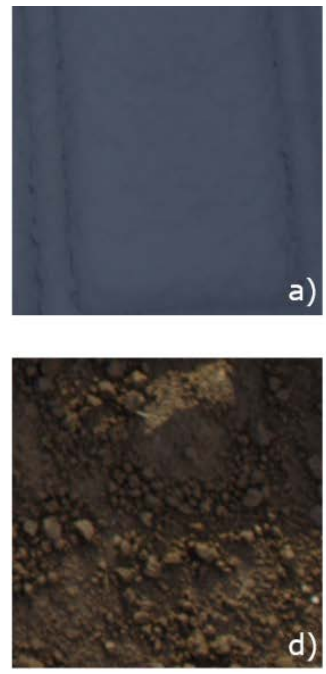
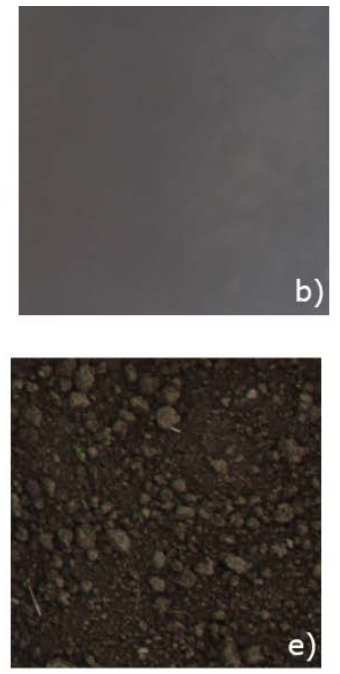
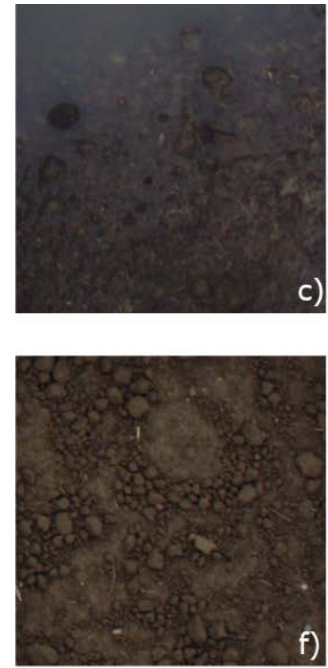

Figure 5-3. Examples of images that are discarded: snow (a); fog (b); standing water $(c)$; sunlight distribution $(d)$; and frozen surface (e). The last image ( $f$ ) is an example of an image accepted for further analysis.

\subsubsection{Shadow ratio}

Various soil properties affect soil's spectral reflectance such as soil particle distribution, organic matter content, soil moisture, iron oxide, soil minerals, presence of salts and soil crusting. The influence of soil structure on soil reflectance has been investigated on sieved soil under controlled laboratory condition. Banninger and Fluhler, (2004) and Wu et al., (2009) have shown that the reflectance decreases with increasing soil particle size or lump size. Soil roughness affects the soil optical properties because more light is kept in the space between the coarse soil aggregates in comparison to finer aggregates or grains. In the field, soil aggregates of various size make the soil surface rough. Soil aggregate leads to self-shadowing of the soil surface resulting in a low reflectance value (Baumgardner et al., 1986). Cierniewski, (1987) found that the shadowing coefficient of the soil surface, which is the proportion of shadowed area per unit area of soil fragments, decreased with a decrease of soil roughness. Also, the reflectance of a rough soil surface diminishes with increasing sun angle (Cierniewski and Verbrugghe, 1997; Matthias et al., 2000). However, if the soil surface is smooth, the reflectance at any sun angle is a function of the colour, soil aggregate and Bidirectional Reflectance Distribution Function (BRDF). Here, no BRDF correction was performed. In the visible spectrum, light scatters more in the blue band compared to green and red bands. Therefore, the blue band has a relatively 
Using Color, Texture and Object-Based I mage Analysis of Multi-Temporal Camera Data to Monitor Soil Aggregate Breakdown

higher intensity value than the red band in shaded areas. Using image band ratio (blue/red), assuming that the pixels in shadowed regions have higher intensity values than those pixels in the non-shadowed region, shadow cast could be detected. Considering that the soil surface roughness causes shadow cast the mean of blue/red band ratio was used to investigate changes of soil aggregate over time. This band ratio (blue/red) was performed using IDL ENVI 5.2 (ENVI, 2015). The shadow ratio was calculated for each pixel in an image with $512 \times 512$ pixels. After the image with shadow value was obtained, the mean and standard deviation of this image is used for further analysis

\subsubsection{Grey Level Co-Occurrence Matrix: Entropy}

Image texture describes spatial variation in an image. The grey level cooccurrence matrix (GLCM) is used here to describe image texture (Haralick et al., 1973). The GLCM implementation in IDL ENVI 5.2 requires selection of a grey level quantization (intensity), an angle to deal with anisotropy and window size. The matrix must contain a grey quantization level in order to obtain a statistically reliable estimate. Although high grey levels provide details, the high grey level quantization increases the computation time. Therefore, a 32 grey level quantization was used in this research. The GLCM in IDL ENVI 5.2 considers multiple orientations $\left(0^{\circ}, 45^{\circ}, 90^{\circ}\right.$, and $\left.135^{\circ}\right)$. However, in our research, the angle of $135^{\circ}$ captures the local variation between neighbouring pixels. The direction of GLCM represents the occurrence of patterns. Reflectance variations causes these patterns due to soil aggregates shadowing at 15:00. Therefore, the sun angle-target-camera position during image acquisition is essential for GLCM. Also, the direction of $135^{\circ}$ of GLCM indicates that the soil aggregates start to break down at the edges. Therefore, the optimal window size is required in dealing with various soil aggregate size. Sometimes, the soil aggregate is more significant than a chosen window size meaning that the GLCM is performed on a homogeneous area. The window size of GLCM was determined when maximal entropy value was reached using the first image of each soil dataset. Due to different soil aggregate size, the window size of GLCM varies depending on the soil dataset used. While the window size of $27 \times 27$ pixels was chosen for Soil 1 , Soil 2 and Soil 3, for Soil 4 and Soil 5 the window $29 \times 29$ pixels and $25 \times 25$ pixels were selected, respectively. The GLCM calculation was performed on the mean of three bands (red, green and blue) using IDL ENVI 5.2. Once the GLCM was calculated, descriptive features such as contrast, dissimilarity, homogeneity, energy, entropy, mean, variance and correlation are derived from this matrix (Anys et al., 1994). To monitor and characterize the disintegration of weak rocks, Rincon et al., (2016) reviewed various image texture features and chose entropy. This research showed that the entropy is an appropriate texture feature for assessing and quantifying the degree of disintegration of the weak rocks. Moreover, this study demonstrated that colour intensities of an image change due to disintegration of weak rocks. Cracks and void space lead to more light absorption and lower entropy value. This intensity change in an image is reflected by entropy. Since the goal of this study is similar to Rincon et al., (2016), the GLCM entropy was selected to investigate soil aggregate breakdown. The entropy is a statistical 
measure that quantifies the amount of uncertainty in an image and is calculated using Equation (5-1)

$$
\text { Entropy }=-\sum_{i=0}^{N_{G-1}} \sum_{j=0}^{N_{G-1}} p(i, j) \log (p(i, j))
$$

where $G$ is grey level, $p$ is the probability of GLCM, $i$ is the intensity in the $X$ direction of GLCM, and $j$ is intensity in the $Y$ direction of GLCM.

The maximal entropy is reached when all probabilities in a matrix are equal. Minimum entropy is achieved when the image is constant meaning all of the pixels have the same grey level. Therefore, the entropy is defined within the limits of $0 \leq$ Entropy $\geq \log _{2} G$. The maximal entropy is not a fixed value because it depends on the G (grey level) used. The entropy is calculated within a window size. Then, its value is assigned to the centre pixel of the window. This procedure is repeated until the pixels in an image have an entropy value. However, the calculation of entropy is not performed at the edges of the image. After the image with entropy values was obtained, the mean and standard deviation of this image was used for further analysis. Soil aggregate breakdown is considered as a random process because it is difficult to identify how it changes under natural conditions. The GLCM entropy might reflect the process of soil aggregate breakdown being a measure of the dispersion of a random variable. While a high entropy value shows the dispersed distribution, a low entropy value indicates a compact distribution of considered phenomenon (soil aggregate breakdown). At the beginning of the experiment, the soil surface was covered with aggregates of various size randomly distributed. As a result, the image is texturally heterogeneous, indicating a high entropy value. Due to weather conditions, the soil aggregate breaks down over time resulting in a smooth soil surface. Thus, the image tends to become constant meaning all the pixels have a similar grey level indicating a low entropy value.

\subsubsection{Object-Based Image Analysis: Huang Thresholding}

When an image has a sufficiently high spatial resolution, pixels are smaller than the object, so the grouping of pixels is possible in order to obtain realworld homogeneous features (Blaschke, 2010). Object-based image analysis (OBIA) approach, which allows estimation of the image area occupied by soil aggregates, was used. OBIA consider not only the spectral reflectance and neighbour relations but also the shape and the size of objects (Addink et al., 2010; van der Werff and van der Meer, 2008). Since the interest is monitoring soil aggregate breakdown, choosing the 1st image of each soil dataset as reference (start of the experiment) is a reasonable choice. Also, images acquired during a day have significant variations caused by illumination differences or changing weather conditions. Therefore, when comparing physical changes in surface properties from different dates, it is necessary to exclude these variations. The exclusion of these variations is achieved by normalizing the images with the reference image. Such normalization was performed using histogram equalization and histogram matching (Lee and Basart, 1999; Ma et al., 2004; Rahman et al., 2015). First, histogram equalization was applied to the reference image. Next, the other images in the 
Using Color, Texture and Object-Based I mage Analysis of Multi-Temporal Camera Data to Monitor Soil Aggregate Breakdown

dataset were imposed on the equalized reference image using histogram matching plugins in I mageJ 1.51c (Rasband, 2016). After images were made comparable to each other, soil aggregates separation from the background was required in order to estimate the area they occupy in an image. This separation was achieved by using a histogram thresholding technique, which classifies the pixels in two classes: object (soil aggregate) and background. When the histogram has no clear separation between object and background, the threshold could be determined using fuzzy theory approach (Tizhoosh, 2005; Wang et al., 2002). The Huang thresholding technique was selected (Huang and Wang, 1995) to identify an appropriate threshold that divides soil aggregate from the background. The Huang thresholding method is based on the fuzzy theory, and membership function $\mu_{A}\left(x_{m n}\right) \in[0,1]$ where $A$ is a fuzzy subset of an image $X(M \times N)$ and $X m n$ is a pixel with a grey level in $X$. The fuzzy subset $A$ is associated with each pixel $X_{m n}$ of the image $X$. The membership function for a pixel with grey level $\left(X_{m n}\right)$ is assigned by:

$\mu_{A}\left(X_{m n}\right)=\frac{1}{1+\left|\left(x_{m n}\right)-\mu_{b}\right| / C}$ if $\left(X_{m n}\right) \leq$ threshold

$\mu_{A}\left(X_{m n}\right)=\frac{1}{1+\left|\left(x_{m n}\right)-\mu_{o}\right| / C}$ if $\left(X_{m n}\right)>$ threshold

where $C$ is a constant value which satisfies $0.5 \leq \mu_{A}\left(X_{m n}\right) \leq 1$ condition, and $\mu_{b}$ and $\mu_{\mathrm{o}}$ are the background and object mean, respectively.

For a given threshold value, the membership of a pixel is assigned to a class (object or background) by the absolute difference between the grey level and the average grey level of its belonging class. If this absolute value is high, then the pixel membership value becomes smaller. The thresholding technique creates a binary image from where the area occupied by soil aggregate can be calculated.

The threshold value of the equalized reference image $(120,107,104,99$ and 108 for Soil 1, Soil 2, Soil 3, Soil 4 and Soil 5, respectively) was used to the other images of the corresponding dataset. Before calculating the aggregate soil area, a calibration procedure that converts an image to metric units was completed. While for Soil 1 and Soil 4, the biggest soil aggregate size was 400 $\mathrm{mm}^{2}$, for the other soils it was $500 \mathrm{~mm}^{2}$. Therefore, soil aggregate sizes ranging from $2 \mathrm{~mm}^{2}$ to $400 \mathrm{~mm}^{2}$ or from $2 \mathrm{~mm}^{2}$ to $500 \mathrm{~mm}^{2}$ depending on the dataset were included in the calculation. These setting were not the same because each dataset had different soil aggregate sizes. The soil aggregates that were touching the image edges were excluded. Figure 5-4 shows an example of the Huang thresholding technique together, with soil aggregates calculated in ImageJ $1.51 \mathrm{c}$. 

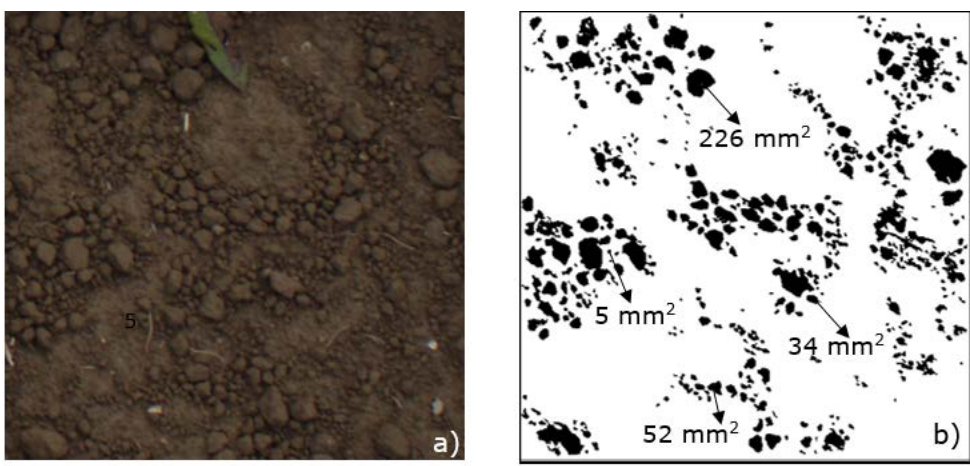

$5^{\text {th }}$ of November 2014
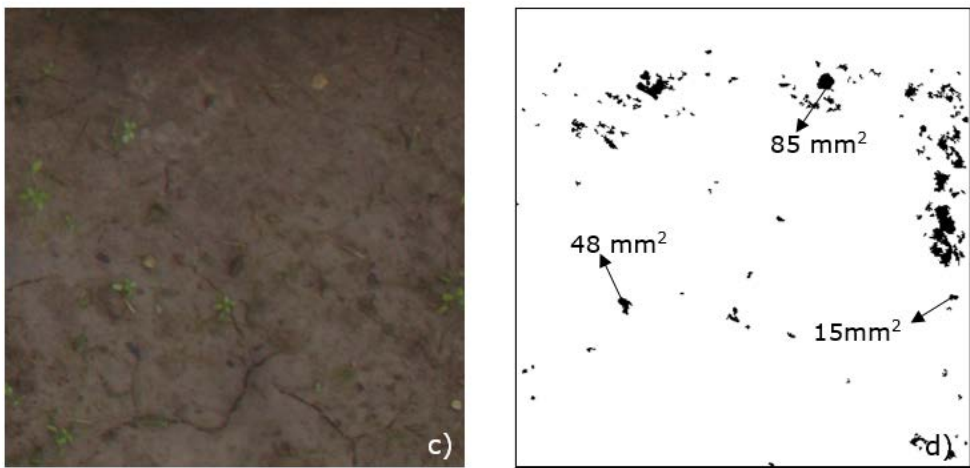

$10^{\text {th }}$ of February 2015

Figure 5-4. On the left side are original images (a, c) of Soil 1. Using the Huang thresholding technique, soil aggregates (black colour) on the right side (b, d) are defined. While images $(a, b)$ show the results at the beginning of the experiment ( 5 November), images ( $c, d$ ) show the results at the end of the experiment (10 February). The area of some aggregates calculated in $\mathrm{mm}^{2}$ is shown as an example.

\subsubsection{Weather Data Collection}

The DAVIS weather station recorded data most of the time, but from 15 to 23 November 2014, missing data occurred. The weather station at Twenthe Airport, located $4 \mathrm{~km}$ away from our experimental site, was used to fill data gaps in the temperature recording. The two stations are mounted at a different height. While DAVIS sensor is installed at $2 \mathrm{~m}$, the sensor at Twenthe airport is at $1.5 \mathrm{~m}$ above ground. Also, the air temperature sensor has a nominal accuracy of $\pm 0.5^{\circ} \mathrm{C}$ and $\pm 0.1{ }^{\circ} \mathrm{C}$ for DAVIS and Twenthe station, respectively. Despite these differences, we found a correlation with a coefficient of determination $\mathrm{R}^{2}=0.96$ for the minimum air temperature between the two stations. For daily rainfall data, the coefficient of determination between the two stations was $\mathrm{R}^{2}=0.31$, meaning that this data could not be used. The 
Using Color, Texture and Object-Based I mage Analysis of Multi-Temporal Camera Data to Monitor Soil Aggregate Breakdown

weather data of Twenthe airport were obtained from the website of the Royal Netherlands Meteorological Institute (KNMI).

\subsection{Results}

Figure $5-5$ shows the original images at three moments in time at the beginning of the experiment (on 6 November 2014), after the first cycle of freeze-thaw followed by most significant rain events (on 15 December 2014), and at the end of the experiment (on 10 February 2015). These observations showed changes at the soil surface over time.

Soil 1
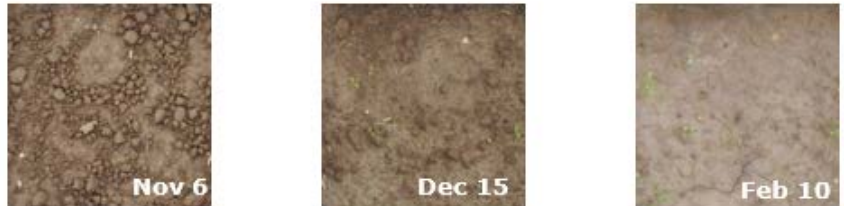

Soil 2
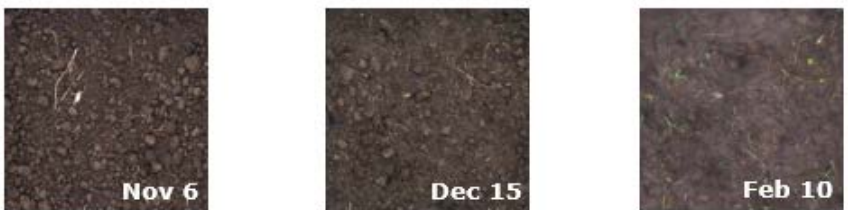

Soil 3
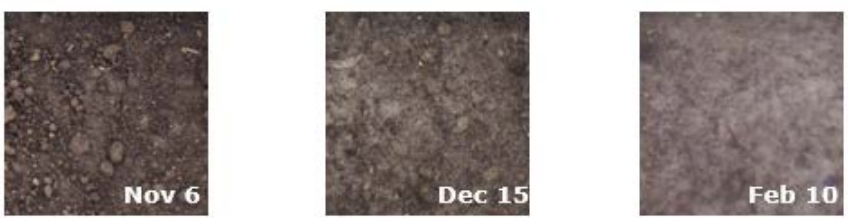

Soil 4
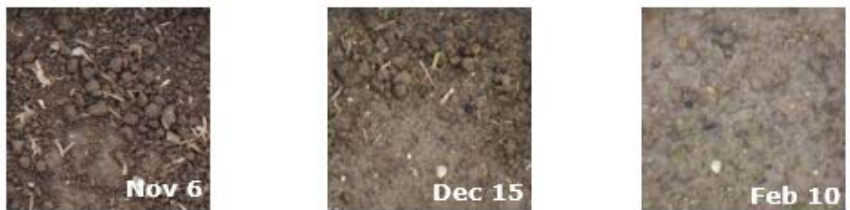

Soil 5
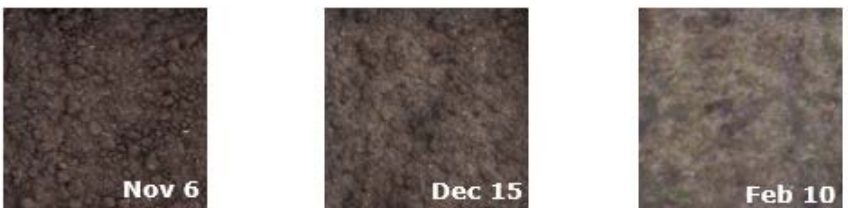
Figure 5-5. Original images for all soils at the beginning of the experiment ( 6 November 2014 images), after the first cycle of freeze-thaw followed by the most significant rain event (15 December 2014 images) and at the end of the experiment (10 February 2015 images). All soils experienced aggregate breakdown over time.

\subsubsection{Weather Data}

For the period that the experiment ran, most of the time rainfall intensity was mostly less than $2.5 \mathrm{~mm} \cdot \mathrm{h}^{-1}$ (light rainfall). However, on 12 and 19 December 2014 and on 2, 8, 10, 13, 15, and 28 January 2015, the rainfall intensity was more than $2.5 \mathrm{~mm} \mathrm{~h}^{-1}$. We considered here daily rainfall data because the images came at the daily base. Since we ran the experiment at wintertime, freezing intervals occurred on 1-4 December 2014, 26-30 December 2014, 20-24 January 2015, and 3-7 February 2015. These four freeze-thaw cycles were followed by rain events on 7-24 December 2014, 2-15 January 2015, 25-31 J anuary 2015 and 9- 10 February 2015, respectively. The minimum air temperature recorded at the Twenthe weather station was used to fill the data gap.

\subsubsection{Shadow Ratio}

The shadow ratio showed a similar trend for all the soil types (Figures 5-6b, 5$7 b, 5-8 b, 5-9 b$ and 5-10b). Weather conditions (freeze-thaw cycles and rain events) seem not to affect the shadow ratio. The most significant rain event $\left(20 \mathrm{~mm} \mathrm{day}^{-1}\right.$ ) on 12 December does not decrease the shadow ratio, although soil splash material was observed at the side of soil trays. In February, the shadow ratio is higher compared to November. Below the results of shadow ratio at the start and the end of the experiment, together with standard deviation were shown. The shadow ratio of Soil 1 varied from $0.62( \pm 0.09)$ to $0.73( \pm 0.06)$. Only in January and afterword, the shadow tended to increase (Figure 5-6b). Soil 1 (Silty Loam with $4.6 \% \mathrm{OM}$ ) is subject to crust development associated with cracks on the soil surface when exposed to various stresses (Figure 5-5). The shadow ratio of Soil 2 varies from 0.76 $( \pm 0.11)$ to $0.85( \pm 0.12)$. Apart from some fluctuations in shadow ratio, Soil 2 shows the same behaviour as Soil 1 (Figure $5-7 b$ ). The shadow ratio of Soil 3 varies from $0.78( \pm 0.11)$ to $0.87( \pm 0.08)$. The shadow ratio stays more or less constant during November and December. An increasing trend is observed in January (Figure $5-8 b$ ). The shadow ratio of Soil 4 (Figure $5-9 b$ ) varies from $0.77( \pm 0.16)$ to $0.80( \pm 0.10)$. This soil has stones on its composition, which are more noticeable at the end of the experiment. The trend of shadow ratio of Soil 4 is similar to Soil 2. Shadow ratio of Soil 5 (Figure 5-10b) varies from $0.79( \pm 0.08)$ to $0.83( \pm 0.10)$, and it has a similar trend with the shadow ratio of Soil 1. The soil surface smooths out over time, causing high soil reflectance value. If a smooth surface had been reached, the value of the shadow ratio would have become constant. When our experiment ended, the process of the aggregate breakdown was still ongoing, and therefore the ratio was still increasing. 
Using Color, Texture and Object-Based I mage Analysis of Multi-Temporal Camera Data to Monitor Soil Aggregate Breakdown
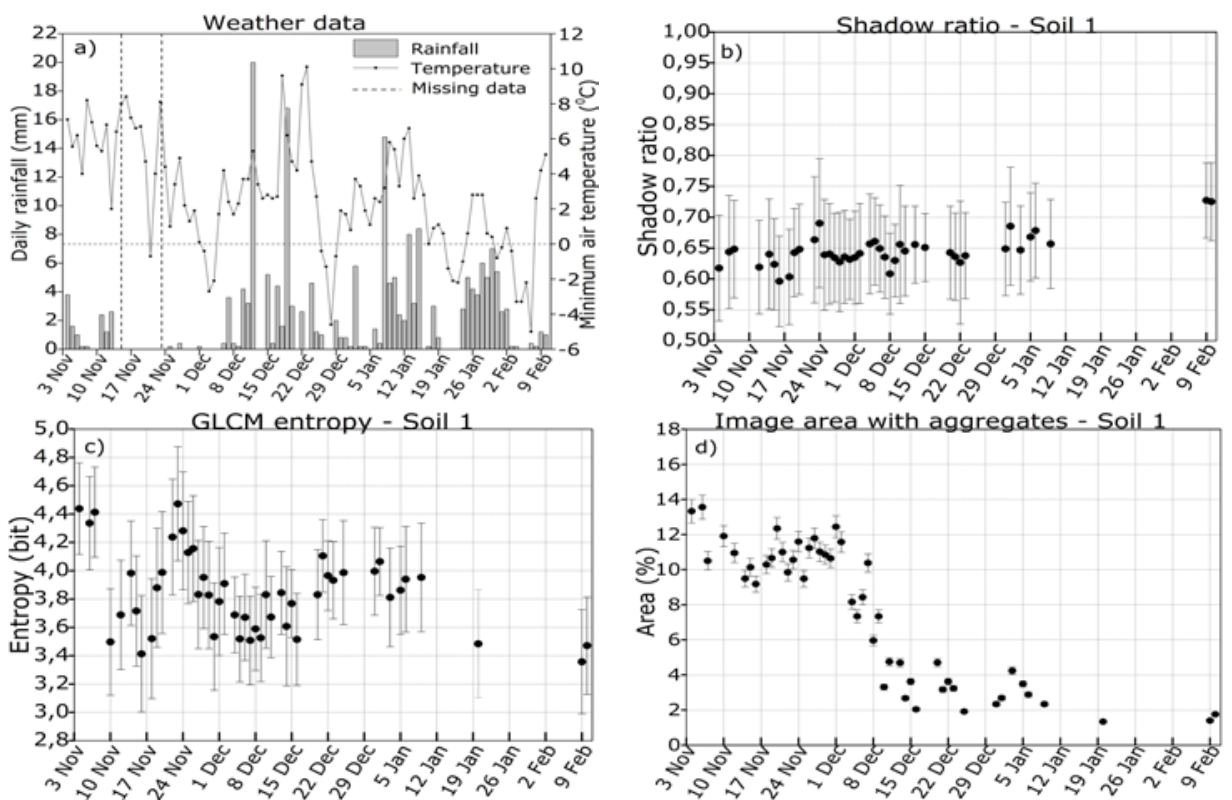

Figure 5-6. Weather data (a) together with shadow ratio (b); entropy (c); and area (d) results of Soil 1 are shown. Grey bars and grey line indicate daily rainfall and minimum air temperature, respectively. The grey dashed horizontal line indicates the temperature in ${ }^{\circ} \mathrm{C}$. The vertical black dashed lines show missing rainfall data interval from 15 to 23 November 2014. The error bars indicate the standard deviation of shadow ratio (b); and entropy (c). The standard error bars of area (d) represent the $95 \%$ confidence interval of the true population mean for the sample size 49 .
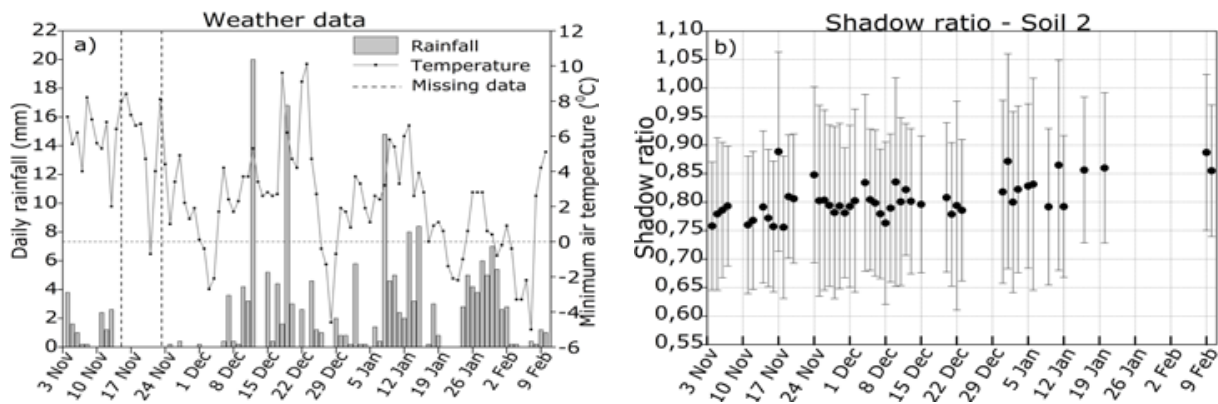

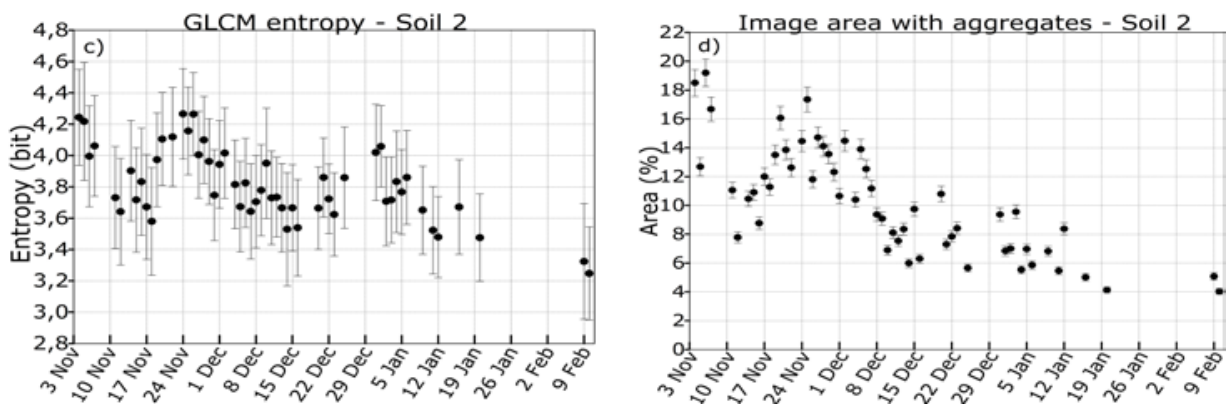

Figure 5-7. Weather data (a) together with shadow ratio (b); entropy (c); and area (d) results of Soil 2 are shown. Grey bars and grey line indicate daily rainfall and minimum air temperature, respectively. The grey dashed horizontal line indicates the temperature in ${ }^{\circ} \mathrm{C}$. The vertical black dashed lines show missing rainfall data interval from 15 to 23 November 2014. The error bars indicate the standard deviation of shadow ratio (b); and entropy (c). The standard error bars of area (d) represent the 95\% confidence interval of the true population mean for the sample size 56 .
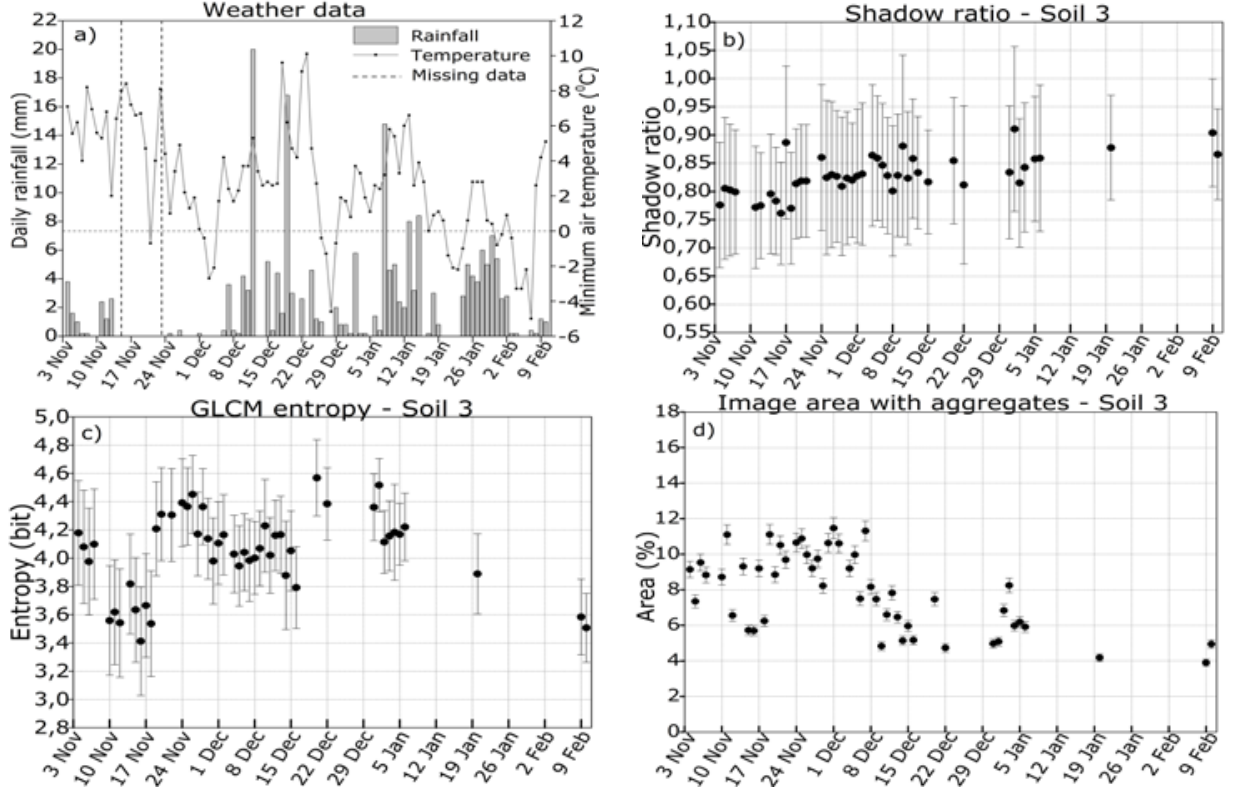

Figure 5-8. Weather data (a) together with shadow ratio (b); entropy (c); and area (d) results of Soil 3 are shown. Grey bars and grey line indicate daily rainfall and minimum air temperature, respectively. The grey dashed horizontal line indicates the temperature in ${ }^{\circ} \mathrm{C}$. The vertical black dashed lines show missing rainfall data interval from 15 to 23 November 2014. The error bars indicate the standard deviation of shadow ratio (b); and entropy (c). The standard error bars of area (d) represent the 95\% confidence interval of the true population mean for the sample size 50 . 
Using Color, Texture and Object-Based Image Analysis of Multi-Temporal Camera Data to Monitor Soil Aggregate Breakdown
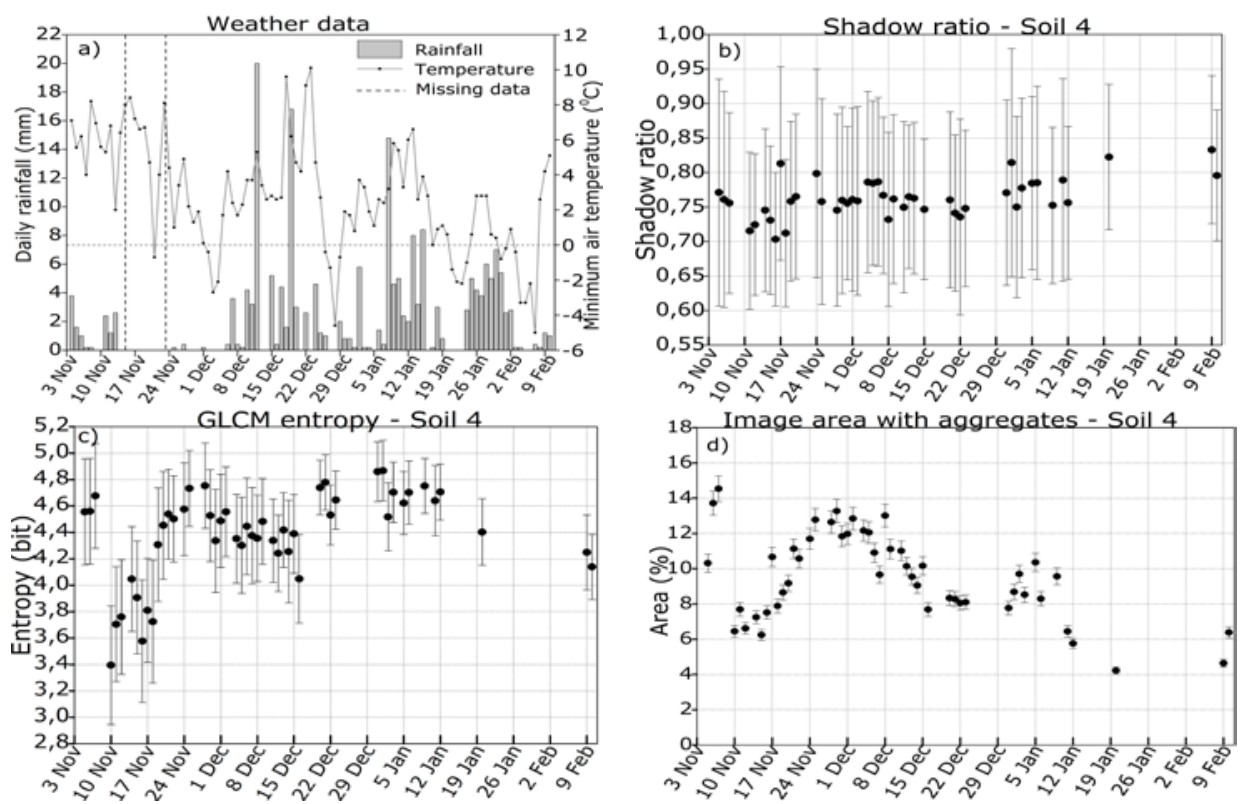

Figure 5-9. Weather data (a) together with shadow ratio (b), entropy (c); and area (d) results of Soil 4 are shown. Grey bars and grey line indicate daily rainfall and minimum air temperature, respectively. The grey dashed horizontal line indicates the temperature in ${ }^{\circ} \mathrm{C}$. The vertical black dashed lines show missing rainfall data interval from 15 to 23 November 2014. The error bars indicate the standard deviation of shadow ratio (b); and entropy (c). The standard error bars of area (d) represent the 95\% confidence interval of the true population mean for the sample size 50 .
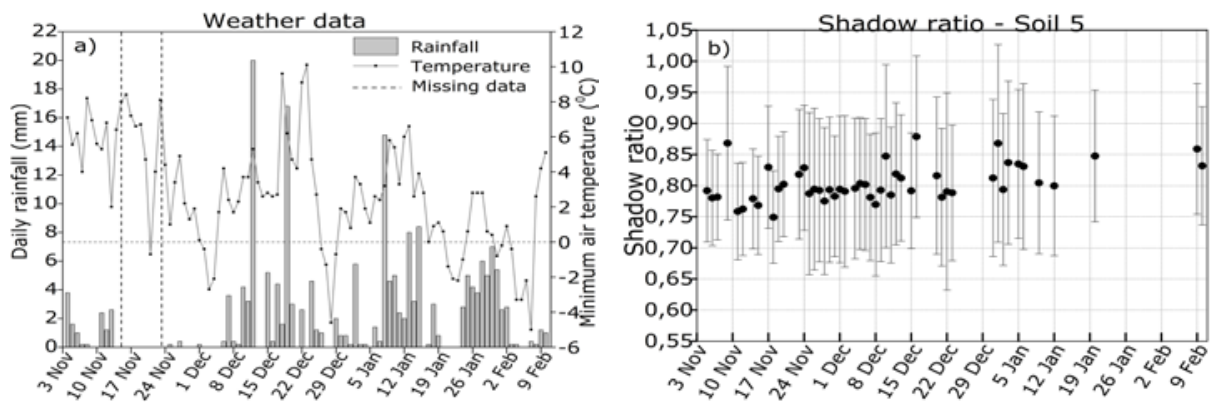

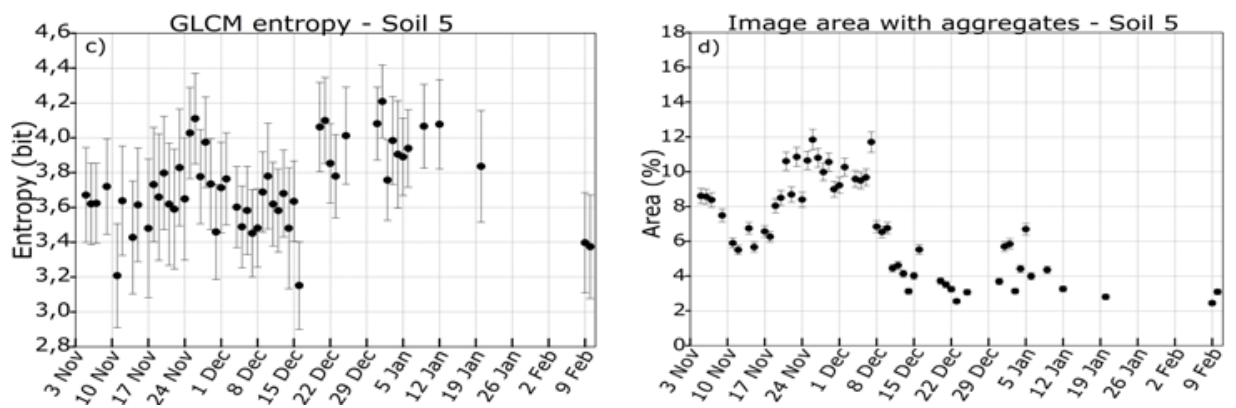

Figure 5-10. Weather data (a) together with shadow ratio (b), entropy (c); and area (d) results of Soil 5 are shown. Grey bars and grey line indicate daily rainfall and minimum air temperature, respectively. The grey dashed horizontal line indicates the temperature in ${ }^{\circ} \mathrm{C}$. The vertical black dashed lines show missing rainfall data interval from 15 to 23 November 2014. The error bars indicate the standard deviation of shadow ratio (b); and entropy (c). The standard error bars of area (d) represent the 95\% confidence interval of the true population mean for the sample size 54 .

\subsubsection{GLCM Entropy}

In Figures 5-6c, 5-7c, 5-8c, 5-9c and 5-10c, it can be seen that the GLCM entropy changes overtime for all the soil types following both freeze-thaw cycles and rain events (Section 5.3.1). Due to light rainfall, the entropy decreases. The entropy decreases further with the rainfall event of 12 December 2014 with a total rainfall of $20 \mathrm{~mm}$ day $^{-1}$. While this behaviour is notable in November and December (Figures 5-6c, 5-7c, 5-8c, 5-9c and 510c), it is less evident in J anuary and February because of missing image data for these months. When there is no rain, or the rainfall amount is $0.2 \mathrm{~mm}$ day $^{-1}$, the entropy increases. During the freezing period ( 1-4 December 2014), an increase in entropy is noticed as soon as the thawing period starts (on 5 December 2014) the entropy decreases. Below the results at the start and the end of the experiment, together with the standard deviation are shown. The entropy of Soil 1 varies from $4.44( \pm 0.32)$ to $3.47( \pm 0.34)$ bits. A decrease of entropy is observed after the biggest rain event $\left(20 \mathrm{~mm} \mathrm{day}^{-1}\right)$ occurred. Moreover, after two cycles of freeze-thaw followed by rain events (beginning and the end of December), the entropy tends to decrease (Figure 5-6c). The entropy of Soil 2 varies from $4.24( \pm 0.31)$ to $3.25( \pm 0.30)$ bits. Here as well the freezing followed by thawing increases and decreases the entropy, respectively. As a result of the big rain event (on 12 December 2014), the entropy decreases. In January, the entropy shows a decreasing trend (Figure $5-7 c)$. The entropy of Soil 3 varies from $4.18( \pm 0.37)$ to $3.51( \pm 0.24)$ bits. Although the entropy decreases when a rain event occurs, and it increases during dry days, the changes are small. The freeze-thaw cycles followed by the rain events (beginning and end of December) do not affect much the entropy. However, after $15 \mathrm{~J}$ anuary 2015, entropy decrease is visible (Figure 5-8c). The entropy of Soil 4 varies from $4.56( \pm 0.40)$ to $4.14( \pm 0.25)$ bits. This soil shows 
Using Color, Texture and Object-Based I mage Analysis of Multi-Temporal Camera Data to Monitor Soil Aggregate Breakdown

first a decrease in entropy. Also, the most significant rain event on 12 December 2014 causes a decrease in entropy. Due to freezing the entropy increases. However, it does not decrease during the thawing period (after 5 December). For the rest of the experiment, the entropy stays high showing a small decreasing trend (Figure 5-9c). The entropy of Soil 5 varies from 3.67 $( \pm 0.27)$ to $3.37( \pm 0.30)$ bits. The entropy follows the freeze-thaw cycles and rain events like the other soils. However, the entropy fluctuations are smaller compared to other soils. From 12 January 2015, the entropy decreases continuously (Figure 5-10c).

\subsubsection{Huang Thresholding Technique}

The image area covered with soil aggregates decreases over time (Figures 5$6 d, 5-7 d, 5-8 d, 5-9 d$ and 5-10d). The percentage of the area does not change much during November. The trigger that initiates the decrease of the area covered with aggregates is freeze-thaw, followed by the rain events in December. The percentage of area covered with soil aggregates reduces significantly after the first freeze-thaw event for all the soils. Below the results at the start and the end of the experiment, together with the standard error (SE) are shown. For Soil 1, the image area covered with soil aggregates decreased from $13.57 \%( \pm 0.66)$ to $1.76 \%( \pm 0.09)$. In November the area covered with soil aggregates remains more or less constant. After the first freezing event (1-4 December 2014) the decrease of the area covered with aggregates is evident (Figure 5-6d). Soil 2 trend is similar to Soil 1 . Image area covered with soil aggregates decreased from $19.2 \%( \pm 0.96)$ to $4.03 \%$ $( \pm 0.20)$. The freezing event (1-4 December 2014) causes a decrease in area percentage. After the most significant rain event $\left(20 \mathrm{~mm}\right.$ day $\left.^{-1}\right)$ on 12 December, the changes are small (Figure 5-7d). The image area of Soil 3 covered with aggregates decreased from $11.47 \%( \pm 0.57)$ to $3.9 \%( \pm 0.20)$. The area decreases because of the first freeze-thaw event (1-4 December 2014). After this moment, the freeze-thaw followed by rain events had little influence on the area (Figure 5-8d). The area covered with soil aggregates of Soil 4 decreased from $14.54 \%( \pm 0.73)$ to $4.23 \%( \pm 0.21)$. This soil shows a different trend compared to previous soils. However, like the other soils, the first freeze-thaw (1-4 December 2014) decreased the area (Figure 5-9d). For Soil 5 , the image area decreased from $11.85 \%( \pm 0.59)$ to $2.45 \%( \pm 0.12)$. Soil 5 has a similar trend with Soil 4 in November. The first freeze-thaw (1-4 December 2014) and the rain events on 12 and 19 December 2014 decreased the area covered with aggregate (Figure 5-10d). After the first freezing event, the SE of all the soils gets smaller, suggesting that the number of soil aggregates decreases due to the freeze-thaw cycle.

Figure 5-11 summarizes the results of shadow ratio, entropy, and image area covered with soil aggregates at the start and the end of the experiment for all the soils. We observe that the shadow ratio is higher at the end of the experiment (Figure 5-11a). Both the GLCM entropy and the image area cover with soil aggregates decrease at the end of the experiment, as observed in Figure 5-11b,c, respectively. 

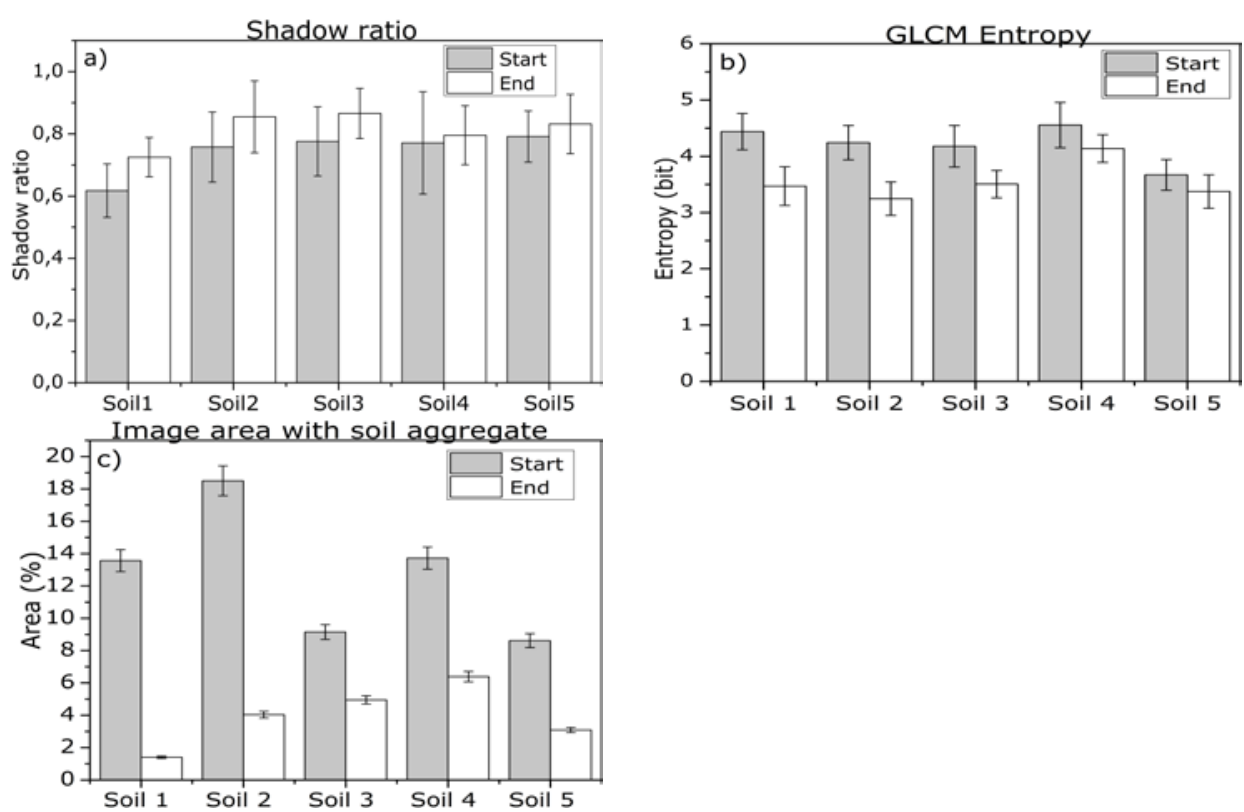

Figure 5-11. Summary results of shadow ratio, entropy and area covered with aggregates obtained for all soils using: band ratio (blue/red) (a); GLCM entropy (b); and Huang thresholding (c) approaches. The grey and white bars indicate the start and the end of the experiment, respectively. Each dataset is relative to each tray and cannot be taken as an absolute value.

\subsection{Discussion}

It is hypothesized that over time soil surface becomes smooth because rainfall or freeze-thaw cycles destroy soil aggregate (Figure 5-5).

\subsubsection{Shadow Ratio}

For all the soil types, the shadow ratio shows a gradual change over time. Although the soil aggregates break down because of freeze-thaw cycles followed by rain events, the shadow ratio does not show details related to weather conditions. In February, the shadow ratio is higher compared to November. These results are related to high reflectance of a smooth soil surface at the end of the experiment. When both bands (blue/red) have the same reflectance value, the shadow ratio becomes constant. The constant shadow ratio indicates that no changes occur at the soil surface. The high shadow ratio at the end of the experiment is more noticeable for Soil 1, Soil 2 and Soil 3 than for Soil 4 and Soil 5 (Figure 5-11a). Due to crust formation at the end of the experiment, the reflectance and consequently, the shadow ratio of Soil 1 is high what it was expected for Soil 1 . Similar to Soil 1 , Soils 2 and 
Using Color, Texture and Object-Based I mage Analysis of Multi-Temporal Camera Data to Monitor Soil Aggregate Breakdown

3 are Silty Loam, but they have high OM content. Soil aggregates are formed by bonding of clay particle, polyvalent minerals ( $\mathrm{Fe}, \mathrm{Al}, \mathrm{Ca}$ ) and organic matter (Emerson, 1967). Therefore, the organic matter is important not only for soil fertility but also for soil structure stability. Although Soil 2 is from agricultural land, and Soil 3 is from a forest area, the shadow ratio of these soils is similar at the end of the experiment. This similarity could be related to a surface crust formation, especially for Soil 3 . These soils are subject to frequent crust development. Therefore, the creation of the white layer could be a result of this process. Moreover, the appearance of wild plants in Soil 2 is noticeable (Figure 5-5). At the end of the experiment, the shadow ratio of Soil 4 (Loam) and Soil 5 (Sandy Loam) increases 0.03 and 0.04 , respectively, when compared to the start of the experiment. The low increase of shadow ratio at the end of the experiment could be related to BRDF, which was not corrected. With a $60^{\circ}$ horizontal field of view, the camera observed more shadow in aggregates viewed towards the sun (Soils 1 and 2) than in aggregates viewed away from the sun (Soils 4 and 5). This implies that interpreted results can be compared between the different trays, but that data values cannot be compared between trays in absolute terms. The difference in solar azimuth overtime is $6.7^{\circ}$, which is negligible for the three measures presented in this study. The difference in solar elevation can, however, lead to a $\sim 50 \%$ difference in shadow length. Different from solar azimuth, it could be expected that changing solar elevation would be visible in the shadow ratio, but the results do not show that at all. A longer time series might have brought this to light. Considering the mean as a signal and the standard deviation as a noise, the Signal-to-Noise ratio (SNR) for each band could be calculated. The high SNR value indicates that the band has more information than noise. For Soil 1 , the SNR of the red band was higher compared to the SNR of the blue band. The opposite was true for other soils. This is the reason why shadow ratio (blue/red) of Soil 1 was lower compared to other soils. Moreover, the standard deviation of shadow ratio is relatively large, because it is related to the number of pixels in the image $(512 \times 512$ pixels $)$.

\subsubsection{GLCM Entropy}

The entropy was able to follow changes on the soil surface for all the soils used in this study. The high and low entropy value indicates that the image is heterogeneous and texturally uniform, respectively. Figure 5-11b shows that the entropy is higher at the beginning of the experiment compared to the end of the experiment. Although rainfall intensity was low $\left(<2.5 \mathrm{~mm} \mathrm{~h}^{-1}\right)$ most of the time that the experiment ran, the soils were at a wet condition. Soil water content at the time of freezing is important because, as the air temperature drops below $0{ }^{\circ} \mathrm{C}$, the soil temperature gets low, causing frozen soil. As a result, the ice crystals expand in pores between the soil particles affecting particle-to-particle bond (Bullock et al., 1988). During freezing days, the entropy was high because the frozen soils had many ways to arrange themselves, revealing a dispersed distribution of the soil aggregates. As soon as the thawing period starts, the soil particles tend to bond again. At this time, the entropy stayed constant or decreased because the soil aggregates had a limited number of ways to bond together, indicating a compact distribution 
with a few grey-level variations. The GLCM entropy showed the same trend for all the soils, except the magnitude, which differed with soil type. This is, of course, related to soil properties affecting the soil aggregate breakdown. Clay is one of the aggregating factors in soil (Denef and Six, 2005; Xu et al., 2015). However, the effect is different depending on its mineralogy. X-ray diffraction of the soil samples indicated that the dominant clay mineral was kaolinite. Also, the organic matter is responsible for the soil structure stability (Abdollahi et al., 2014; Annabi et al., 2011). Both, Soil 1 and Soil 4 have a low OM and a high percentage of silt particles making these soils vulnerable to the freezethaw cycles and the rain events. However, the entropy changes for Soil 4 are smaller compared to Soil 1 overtime. This could be related not only with the stony composition of Soil 4 but also with a lower silt amount (44\%) in Soil 4 compared to Soil $1(71 \%)$. Soil 2 (agricultural land) had a lower entropy value than Soil 3 (forested land) at the end of the experiment. This means that the land use/land cover affects soil resistance to freeze-thaw and rainfall impact. Unlike the shadow ratio, the GLCM entropy was able to distinguish the importance of land use/land cover on soil aggregate breakdown. The entropy of Sandy Loam (Soil 5) was calculated over a more homogeneous image (similar aggregate size) with fewer intensity variations compared to the other soils. This is a reason why Sandy Loam had lower entropy values. This soil type drains and dries out more rapidly than the clayey soils. Therefore, freezing has little effect on dried soil, indicating the importance of the soil water content at the freezing time.

Entropy is not calculated at the edges of an image. Although the image size decreases depending on the window size used, the standard deviation of the entropy is relatively large because it depends on the number of analysis windows.

\subsubsection{The Huang Thresholding Technique}

The results obtained using the Huang thresholding technique were the best (small error bars indicate high precision) compared to both shadow ratio and GLCM entropy (wide error bars indicating a large error). The Huang thresholding method was able to quantify the soil aggregates changes over time. As mentioned in Sections 5.4.1 and 5.4.2 (shadow ratio and GLCM entropy), it is the combination of freeze-thaw cycles followed by rain events that trigger the soil aggregate breakdown.

Soil aggregate stability is its ability to maintain its structural arrangement and void spaces when exposed to various stresses. Freeze-thaw cycles affect soil aggregate stability (Chai et al., 2014; Dagesse, 2013). However, this effect varies with soil texture, OM content, initial aggregate size, soil water content at the time of freezing, freezing temperature, number of freeze-thaw cycles. Likewise, the raindrop impact affects the soil surface in different ways. When the soil is dry, aggregate disruption by splashing is most effective (Furbish et al., 2007; Mouzai and Bouhadef, 2003). The impact of a raindrop on the wet soil plays a role in compaction (Le Bissonnais, 1996). Also, Algayer et al., (2014) showed that the soil aggregate stability varied in a few days, and this was related to the soil water content and rainfall intensity. 
Using Color, Texture and Object-Based I mage Analysis of Multi-Temporal Camera Data to Monitor Soil Aggregate Breakdown

It is interesting to observe that Soil 2 with a high OM content had the highest loss of soil aggregates compared to the other soils as it is shown in Figure 511c. Soil 2 is from agricultural land. The high OM content in Soil 2 is probably coming from sewage sludge manure mixed with plant residues application by the farmer some days before the soil sample was taken. The manure had probably not yet appropriately mixed with the soil matrix since it is not normal to have such a high amount of OM in agricultural fields. Soil 3 with high OM is from the forested area. This soil had the lowest soil aggregates loss compared to other soils. In a study of the accumulated effect of rain on micro-topographic erosion features in various land uses under natural conditions (Kunwar et al., 2003) reported higher erosion hazard in agricultural fields and lower in forest cover indicating the pronounced effect of the land cover on aggregate stability. These results also indicate that forested soils are more resistant to freeze-thaw cycles, followed by rain events than agricultural ones. Although the OM content of Soil 2 and 3 is very similar, they act differently under freezing and thawing. This could be related to the difference in origin in OM. Soil 2 sewage sludge could have higher water retention characteristics than the more apolar OM of forested soils (Soil 3). Therefore, Soil 2 (agricultural soil) expansion during the freezing result in more aggregate breakdown compares to Soil 3 (forested soil). As mentioned in Section 5.4.2 (GLCM entropy), Soil 5 (Sandy Loam) drains fast, and freezing has little influence on it. Soil 1 (Silty Loam) and Soil 4 (Loam) both have low OM, but different amount of silt particles which make them behave differently. Soil 1 at the end of the experiment shows crust formation, which cannot be seen for Soil 4 (Figure 5-5). Besides the soil properties, these results are influenced by soil aggregate size at the beginning of the experiment. In Section 5.2.5, it was specified that the smallest aggregate size is $2 \mathrm{~mm}^{2}$, and the biggest one is $400 \mathrm{~mm}^{2}$ (Soil 1 and Soil 4) and $500 \mathrm{~mm}^{2}$ for the other soils. Within this range $\left(2-400\right.$ or $\left.2-500 \mathrm{~mm}^{2}\right)$, soil aggregate sizes vary significantly. Although we were not able to follow each soil aggregate change over time, at the end of the experiment the average soil aggregate size was $16 \mathrm{~mm}^{2}, 12 \mathrm{~mm}^{2}, 17 \mathrm{~mm}^{2}, 17 \mathrm{~mm}^{2}, 13 \mathrm{~mm}^{2}$ for Soil 1, Soil 2, Soil 3, Soil 4 and Soil 5, respectively.

Moreover, by visual inspection, it is observed that the size of the aggregates of Soil 2 is smaller compared to other soils at the beginning of the experiment (Figure 5-5). These results might indicate that while small aggregates are destroyed, the big ones decrease in size. This is an objective for further work to quantify how much individual soil aggregates change over time.

When looking at relative changes over time, no absolute calibration per se is needed. Both the band ratio and the grey level matrix do not depend on absolute data values, while the Huang technique was performed on data normalized with histogram matching on each of the five image subsets separately. If, for example, vegetation would have started to grow, a histogram matching normalization would likely not suffice. In this experiment, however, there was only bare soil during the experiment. There was no apparent change in surface composition, other than changes in sand and clay fractions.

In soil erosion models, it is well recognized the importance of soil surface conditions and the need to take into account their spatial and temporal heterogeneity. RS can play a significant role in acquiring relevant data for soil erosion models in order to improve their performance.

Besides climate, in agricultural area soil aggregates are affected by cultivation practices. Soil is less exposed to raindrop impact during the cropping season 
due to crop canopy. It is essential to identify periods of low stability when the soil is particularly vulnerable to structural breakdown. Good ground cover is an integral part of the majority of soil conservation programs. At this stage of the research, the potential users can be the scientific community dealing with soil erosion modelling and environmental concern. Further investigation is needed to make these results practical to the decision-makers and farmers.

\subsection{Conclusions}

In this study, band ratio, image texture analysis and object-based image analysis derived from standard photography were used to monitor soil aggregate break down under natural conditions. Five different soils were chosen, varying in texture classes (Silty Loam, Sandy Loam and Loam) and organic matter content (agricultural soil and forest soil). Trays with aggregates were exposed to outside weather circumstances during the winter season, with exposure to rainfall and freeze-thaw cycles. The winter season (October to March) was used as the soils in the Netherlands usually are bare, and aggregate breakdown takes place. Images with fog, inundation, freezing and inhomogeneous lighting were discarded. A weather station adjacent to the plots recorded all meteorological variables.

The assumption is that the aggregates break down under the kinetic energy of rainfall and freeze-thaw cycles, and smooth the surface. A decrease in aggregate size and loss of aggregates should be visible in the image series, and different indices derived from these images might serve as roughness indicators. Of the three image-derived indices, shadow ratio is the worst. The assumption is that large aggregates cast a larger shadow than small aggregates, but in reality, many roughness elements cause shadows, also because the sun during winter is at a low angle $\left(13.6-17.5^{\circ}\right.$ at the experimental site). The effect of aggregate breakdown cannot be well observed, and there is no relation between shadow ratio and rainfall or air temperature. The texture index (GLCM entropy) is moderately successful in the decreasing trend with cumulative rainfall, but the index is complex to compute and has to be optimized for a given situation. Both shadow ratio and GLCM entropy have relatively large standard deviations. The Huang thresholding technique captures the aggregates themselves and successfully shows a decrease in size, with a low standard deviation. Given sufficient resolution of the images, the aggregate breakdown can be followed by this method. The low standard deviation is logical as the number of aggregates is much smaller than the number of pixels (shadow ratio) or the number of analysis windows (GLCM entropy). Therefore, the standard deviation should not be used as a comparative among approaches. 
Using Color, Texture and Object-Based I mage Analysis of Multi-Temporal Camera Data to Monitor Soil Aggregate Breakdown

\subsection{References}

Abdollahi, L., Schjønning, P., Elmholt, S., Munkholm, L. J., 2014. The effects of organic matter application and intensive tillage and traffic on soil structure formation and stability. Soil and Tillage Research. 136(0), 28-37.

Addink, E. A., De Jong, S. M., Davis, S. A., Dubyanskiy, V., Burdelov, L. A., Leirs, H., 2010. The use of high-resolution remote sensing for plague surveillance in Kazakhstan. Remote Sensing of Environment. 114(3), 674-681. Agassi, M., Shainberg, I., Morin, J., 1981. Effect of Electrolyte Concentration and Soil Sodicity on Infiltration Rate and Crust Formation1. Soil Science Society of America Journal. 45(5), 848-851.

Algayer, B., Le Bissonnais, Y., Darboux, F., 2014. Short-Term Dynamics of Soil Aggregate Stability in the Field. Soil Science Society of America J ournal. 78(4), 1168-1176

Annabi, M., Le Bissonnais, Y., Le Villio-Poitrenaud, M., Houot, S., 2011. Improvement of soil aggregate stability by repeated applications of organic amendments to a cultivated silty loam soil. Agriculture Ecosystems \& Environment. 144(1), 382-389.

Anys, H., Bannari, A., He, D. C., Morin, D., Environm Res Inst, M., 1994. Texture analysis for the mapping of urban areas using airborne MEIS-II images. Ann Arbor, Environmental Research Inst Michigan.

Bajracharya, R. M., Lal, R., Hall, G.F., 1998. Temporal variation in properties of an uncropped, ploughed Miamian soil in relation to seasonal erodibility. Hydrological Processes. 12(7), 1021-1030.

Banninger, D., Fluhler, H., 2004. Modeling light scattering at soil surfaces. IEEE Transactions on Geoscience and Remote Sensing. 42(7), 1462-1471.

Baumgardner, M.F., Silva, L.F., Biehl, L.L., Stoner, E.R., 1986. Reflectance Properties of Soils. Advances in Agronomy. NC. Brady, Academic Press. Volume 38, 1-44.

Ben-Dor, E., Goldlshleger, N., Benyamini, Y., Agassi, M., Blumberg, D.G., 2003. The Spectral Reflectance Properties of Soil Structural Crusts in the 1.2to 2.5- $\mu$ m Spectral Region. Soil Sci. Soc. Am. J. 67(1), 289-299.

Ben-Dor, E., Inbar, Y., Chen, Y., 1997. The reflectance spectra of organic matter in the visible near-infrared and short wave infrared region (400-2500 $\mathrm{nm}$ ) during a controlled decomposition process. Remote Sensing of Environment. 61(1), 1-15

Ben-Dor, E., Patkin, K., Banin, A., Karnieli, A., 2002. Mapping of several soil properties using DAIS-7915 hyperspectral scanner data - a case study over clayey soils in Israel. International Journal of Remote Sensing. 23(6), 10431062.

Blaschke, T., 2010. Object based image analysis for remote sensing. ISPRS J ournal of Photogrammetry and Remote Sensing. 65(1), 2-16.

Bullock, M. S., Kemper, W. D., Nelson, S.D., 1988. Soil cohesion as affected by freezing, water-content, time and tillage. Soil Science Society of America J ournal. 52(3), 770-776.

Cerdan, O., Souchère, V., Lecomte, V., Couturier, A., Le Bissonnais, Y., 2002. Incorporating soil surface crusting processes in an expert-based runoff model: Sealing and Transfer by Runoff and Erosion related to Agricultural Management. Catena. 46(2-3), 189-205. 
Chai, Y.J., Zeng, X.B.E.S.Z., Bai, L.Y., Su, S.M., Huang, T., 2014. Effects of freeze-thaw on aggregate stability and the organic carbon and nitrogen enrichment ratios in aggregate fractions. Soil Use and Management. 30(4), 507-516.

Cierniewski, J., 1987. A model for soil surface roughness influence on the spectral response of bare soils in the visible and near-infrared range. Remote Sensing of Environment. 23(1), 97-115.

Cierniewski, J., Verbrugghe, M., 1997. Influence of soil surface roughness on soil bidirectional reflectance. International Journal of Remote Sensing. 18(6), 1277-1288.

Collingwood, A., Treitz, P., Charbonneau, F., 2014. Surface roughness estimation from RADARSAT-2 data in a High Arctic environment. International Journal of Applied Earth Observation and Geoinformation. 27, Part $A(0), 70$ 80.

Croft, H., Anderson, K., Kuhn, N.J ., 2009. Characterizing soil surface roughness using a combined structural and spectral approach. European Journal of Soil Science. 60(3), 431-442.

Cruse, R. M., Larson, W.E., 1977. Effect of Soil Shear Strength on Soil Detachment due to Raindrop Impact. Soil Science Society of America J ournal. 41(4), 777-781.

Dagesse, D.F., 2013. Freezing cycle effects on water stability of soil aggregates. Canadian J ournal of Soil Science. 93(4), 473-483.

DAVIS., 2010. Vantage Pro2 Integrated sensor suite installetion manual. from www.davisnet.com.

de Jong, S. M., 1992. The analysis of spectroscopical data to map soil types and soil crusts of Mediterranean eroded soils. Soil Technology. 5(3), 199-211. Denef, K., Six, J., 2005. Clay mineralogy determines the importance of biological versus abiotic processes for macroaggregate formation and stabilization. European journal of soil science. 56(4), 469-479.

Emerson, W.W., 1967. A classification of soil aggregates based on their coherence in water. Australian J ournal of Soil Research. 5(1), 47-\&.

ENVI., 2015. Exelis Visual Information Solutions. from http://www.harrisgeospatial.com/.

Eshel, G., Levy, G.J., Singer, M.J., 2004. Spectral reflectance properties of crusted soils under solar illumination. Soil Science Society of America Journal 68(6), 1982-1991.

Farrand, W.H., Harsanyi, J.C. 1997. Mapping the distribution of mine tailings in the Coeur d'Alene River Valley, Idaho, through the use of a constrained energy minimization technique. Remote Sensing of Environment. 59(1), 6476.

Furbish, D.J., Hamner, K.K., Schmeeckle, M., Borosund, M.N., Mudd, S.M., 2007. Rain splash of dry sand revealed by high-speed imaging and sticky paper splash targets. J ournal of Geophysical Research-Earth Surface. 112(F1), 19.

Gessesse, G. D., Fuchs, H., Mansberger, R., Klik, A., Rieke-Zapp, D.H., 2010. Assessment of Erosion, Deposition and Rill Development On Irregular Soil Surfaces Using Close Range Digital Photogrammetry. Photogrammetric Record. 25(131), 299-318.

Haralick, R.M., Shanmugam, K., Dinstein, I.H. 1973. Textural Features for Image Classification. Systems, Man and Cybernetics, IEEE Transactions on SMC. 3(6), 610-621. 
Using Color, Texture and Object-Based I mage Analysis of Multi-Temporal Camera Data to Monitor Soil Aggregate Breakdown

Huang, L.K., Wang, M.J.J., 1995. Image thresholding by minimizig the measures of fuzziness. Pattern Recognition. 28(1), 41-51.

KNMI., Downloading weather data from Twenthe station. Retrieved J une, 27, 2016, from https://www.knmi.nl/.

Kornelsen, K.C., Coulibaly, P., 2013. Advances in soil moisture retrieval from synthetic aperture radar and hydrological applications. Journal of Hydrology. 476, 460-489.

Kunwar, L.B., Bergsma, E., Shrestha, D.P., 2003. Rain erosion hazard evaluated from microtopographic erosion features on arable fields and forest: A case study in Nepal. Geografiska Annaler Series a-Physical Geography. 85A(3-4), 313-321.

Kværnø, S. H., Øygarden, L., 2006. The influence of freeze-thaw cycles and soil moisture on aggregate stability of three soils in Norway. Catena. 67(3), 175- 182.

Le Bissonnais, Y., 1996. Aggregate stability and assessment of soil crustability and erodibility: I. Theory and methodology Stabilité structurale et évaluation de la sensibilité des sols à la battance et à l'érosion: I: Théorie et méthologie. European Journal of Soil Science. 47(4), 425-437.

Lee, J., Basart, J.P., 1999. A new algorithm for multi-spectral calibration in remotely sensed color photography. Applications of Digital Image Processing Xxii. A.G. Tescher. Bellingham, Spie-Int Soc Optical Engineering. 3808, 334345.

Legout, C., Leguedois, S., Le Bissonnais, Y., 2005. Aggregate breakdown dynamics under rainfall compared with aggregate stability measurements. European J ournal of Soil Science. 56(2), 225-237.

Ma, J.W., Zhao, Z.M., Song, J.H., Zeng, Q.Y., Tang, P., Phei., 2004. An automatic method of area change detection based on histogram matching and morphological operation in high spatial remote sensed imagery. Beijing, Publishing House Electronics Industry.

Marzahn, P., Rieke-Zapp, D., Ludwig, R., 2012. Assessment of soil surface roughness statistics for microwave remote sensing applications using a simple photogrammetric acquisition system. ISPRS Journal of Photogrammetry and Remote Sensing. 72, 80-89.

Matthias, A.D., Fimbres, A., Sano, E.E., Post, D.F., Accioly, L., 2000. Surface roughness effects on soil albedo. Soil Science Society of America Journal. 64(3), 1035-1041.

Moreno, R.G., Requejo, A.S., Altisent, J.M. D., Álvarez, M.C.D., 2011. Significance of soil erosion on soil surface roughness decay after tillage operations. Soil and Tillage Research. 117, 49-54.

Mouzai, L., Bouhadef, M., 2003. Water drop erosivity: Effects on soil splash. Journal of Hydraulic Research. 41(1), 61-68.

Mulla, D.J., Huyck, L.M., Reganold, J.P., 1992. Temporal variations in aggregate stability on conventional and alternative farms. Soil Science Society of America J ournal. 56(5), 1620-1624.

Ouédraogo, M.M., Degré, A., Debouche, C., Lisein, J., 2014. The evaluation of unmanned aerial system-based photogrammetry and terrestrial laser scanning to generate DEMs of agricultural watersheds. Geomorphology. 214, 339-355.

Plante, A. F., Feng, Y., McGill, W.B., 2002. A modeling approach to quantifying soil macroaggregate dynamics. Canadian J ournal of Soil Science. 82(2), 181190. 
Puget, P., Chenu, C., Balesdent, J., 2000. Dynamics of soil organic matter associated with particle-size fractions of water-stable aggregates. European J ournal of Soil Science. 51(4), 595-605.

Rahman, M.M., Hay, G.J., Couloigner, I., Hemachandran, B., Bailin, J., 2015. A comparison of four relative radiometric normalization (RRN) techniques for mosaicing $\mathrm{H}$-res multi-temporal thermal infrared (TIR) flight-lines of a complex urban scene. ISPRS J ournal of Photogrammetry and Remote Sensing. 106, 8294.

Rasband, W.S., 2016. ImageJ. Bethesda, Maryland, USA, U.S. National Institutes of Health.

Rincon, O., Shakoor, A., Ocampo, M., 2016. Investigating the reliability of H/V spectral ratio and image entropy for quantifying the degree of disintegration of weak rocks. Engineering Geology. 207, 115-128.

Salisbury, J. W., D'Aria, D.M., 1992. Infrared (8-14 $\mu \mathrm{m}$ ) remote sensing of soil particle size. Remote Sensing of Environment. 42(2), 157-165.

Seung-Bum, K., Leung, T., J ohnson, J. T., Shaowu, H., van Zyl, J. J., Njoku, E. G., 2012. Soil Moisture Retrieval Using Time-Series Radar Observations Over Bare Surfaces. Geoscience and Remote Sensing, IEEE Transactions on 50(5), 1853-1863.

Shainberg, I., Levy, G. J., Rengasamy, P., Frenkel, H., 1992. Aggregate stability and seal formation as affected by drops imapct energy and soil amendments. Soil Science. 154(2), 113-119.

Shrestha, D. P., Suriyaprasit, M., Prachansri, S., 2014. Assessing soil erosion in inaccessible mountainous areas in the tropics: The use of land cover and topographic parameters in a case study in Thailand. Catena. 121, 40-52.

Shrestha, D. P., Zinck, J. A., Van Ranst, E., 2004. Modelling land degradation in the Nepalese Himalaya. Catena. 57(2), 135-156.

Snapir, B., Hobbs, S., Waine, T.W., 2014. Roughness measurements over an agricultural soil surface with Structure from Motion. ISPRS Journal of Photogrammetry and Remote Sensing. 96(0), 210-223.

Stoner, E.R., Baumgardner, M.F., 1981. Characteristic variations in reflectance of surface soils. Soil Science Society of America J ournal. 45(6), 1161-1165.

Taconet, O., Ciarletti, V., 2007. Estimating soil roughness indices on a ridgeand-furrow surface using stereo photogrammetry. Soil \& Tillage Research. 93(1), 64-76.

Tizhoosh, H.R., 2005. Image thresholding using type II fuzzy sets. Pattern Recognition. 38(12), 2363-2372.

van der Werff, H.M.A., van der Meer, F.D., 2008. Shape-based classification of spectrally identical objects. ISPRS Journal of Photogrammetry and Remote Sensing. 63(2), 251-258.

van Reeuwijk, L.P., 2002. Procedures for soil analysis. Technical Paper No. 9. t. edition. Droevendaalsesteeg 3, 6708 PB Wageningen, The Netherlands, ISRIC, Wageningen.

Wang, Q., Chi, Z., Zhao, R., 2002. Image Thresholding by Maximizing the Index of Nonfuzziness of the 2-D Grayscale Histogram. Computer Vision and Image Understanding. 85(2), 100-116.

Wu, C.-Y., Jacobson, A.R., Laba, M., Baveye, P.C. 2009. Accounting for surface roughness effects in the near-infrared reflectance sensing of soils. Geoderma. 152(1-2), 171-180. 
Using Color, Texture and Object-Based I mage Analysis of Multi-Temporal Camera Data to Monitor Soil Aggregate Breakdown

Xu, C.-Y., Yu, Z.-H., Li, H., 2015. The coupling effects of electric field and clay mineralogy on clay aggregate stability. J ournal of Soils and Sediments. 15(5), 1159-1168. 


\section{Synthesis}




\subsection{Soil aggregation and soil stability}

Soil is an essential natural resource that supports life on earth. When soil quality is degraded, its production capacity or its role in ecosystem services decreases. Excessive soil erosion may cause problems not only on-site but also off-site due to sedimentation on the river bed, reservoir and causing flooding down the slope. Extreme climate and human interventions further aggravate soil degradation. It is thus necessary to prevent soil degradation in time. Soil erosion by water is primarily related to particle detachment and transport by surface runoff. Erodibility or soil susceptibility to erosion depends on particle distribution and constituents (e.g. organic matter, iron oxide, carbonates) that help soil aggregation. Iron hydroxides can interact with both the clay minerals and organic compounds to form clay-mineral-organic associations, acting as binding and cementing agents in soil aggregation. The clay forms bridges with the polyvalent metal and the organic matter in the soils with a 2:1 layer structure. Therefore, investigating the changes in the clay minerals at various moisture conditions is important. Moreover, it is crucial to examine the behaviour of the organo-clay minerals interactions at the freeze-thaw cycles.

\subsubsection{The influence of clay minerals in soil aggregation}

The interactions of the organo-hydroxide, organo-clay minerals and phyllosilicate-hydroxide minerals occurring in the soil vary with mineral structure, soil solution, ionic strength and $\mathrm{pH}$ (Qafoku, 2015). Any alteration of these organo-mineral interactions due to the moisture variations needs to be identified. In section 3.3, the results showed that the soil surface minerals behaved differently, depending on the soil type (various organic matter content) and soil treatment (drying-field capacity, field capacity and waterlogging-field capacity). While for the soils with organic matter, the mineralogical alterations were evident at field capacity state, as it is shown in section 3.3.2, for the one with no organic matter, these changes were insignificant. Moreover, regardless of the soil type, the minerals were stable at the drying-field capacity and waterlogging-field capacity treatments as presented in sections 3.3.1 and 3.3.3, respectively.

The high clay content increases the soil cohesion and decreases permeability for the dissolved and colloidal compounds making the leaching process less pronounced. Therefore, high clay content has a positive influence on soil stability. In this research, Soil 3 with $23 \%$ kaolinite showed fewer variations at the waterlogging-field capacity treatment than Soil 2 with $16 \%$ kaolinite. Of course, the clay content and the clay mineralogy significantly affect the soil organo-minerals interactions. In the soils dominated by $1: 1$ clay minerals, the aggregation occurs due to the minerals' binding capacity. Moreover, positively charged Fe/Al oxides and negatively charged 1:1 clay minerals form steady aggregates through attractive electrostatic forces.

The clay forms bridges with the polyvalent metal and the organic matter in the soils with a 2:1 layer structure. The 2:1 clay minerals have a high specific surface area and cation exchange capacity. These clay minerals retain the organic matter in their interlayer spaces, forming an organic coating on the clay particles. However, the 2:1 clay minerals are characterized by shrinking 
during drying and swelling during wetting. Therefore, drying-wetting cycles might decrease the bonding between particles affecting the chemical stabilization.

One of the biotic factors influencing soil aggregation is microorganisms. The microorganisms interact with phyllosilicates and metal oxides as a glueing agent forming and stabilizing the micro soil aggregates (Totsche et al., 2018). It is necessary to investigate the clay minerals behaviour at various moisture conditions and different organic matter types.

\subsubsection{The influence of the freeze-thaw process}

Knowledge about minerals' ability to sorb and stabilize the organic matter under the freeze-thaw process is still limited. With ongoing climate change, the freeze-thaw process is expected to increase its frequency and intensity. The freeze-thaw process breaks down the soil aggregates altering the initial soil stability. However, the soil mineralogical behaviour resulting from the freezethaw process at different moisture conditions is not apparent. Therefore, the investigation of the soil surface minerals behaviour under the freeze-thaw process is performed. In section 4.3 , the results showed that the soil minerals behaved differently under freeze-thaw cycles, depending on the soil type (various organic matter content) and soil moisture conditions (field capacity and waterlogging as reported in section 4.3.1 and 4.3.2, respectively). Likewise, the results suggest that the amount and the type of organic matter are vital in soil experiencing freeze-thaw cycles. Freeze-thaw cycles decrease the bonding strength between particles, increase the pore sizes due to the ice formation inside the clay, altering the structure and the properties of the clay. Therefore, clay minerals' behaviour depends on the type and the content of clay minerals (e.g., kaolinite), their degree of saturation, the frequency, and the magnitude of the freeze-thaw process. Since the clay minerals significantly affect the soil organo-mineral interactions, it is crucial to investigate their behaviour at the freeze-thaw cycles. The way that the freeze-thaw cycles affect the soil particle bonding of 1:1 and 2:1 clay minerals needs to be clarified.

Soil is a complex mixture of solids, liquids and gases. Therefore, various chemical reactions occur in the soil, such as the dissolution of metal oxides, reaction between solutes and water, dissolved gases, or reaction between different solutes. These chemical reactions in cold regions differ from those in warm ones because of the accelerated reactions in ice. These ice reactions are related to the freeze concentration effect, which concentrates the solutes and dissolved gases in the water area of ice, intensifying the chemical reactions (Kim et al., 2017). These chemical reactions need attention too.

\subsubsection{The use of object-based image analysis to monitor aggregate breakdown}

In this research, the soil aggregate breakdown under natural conditions was investigated using colour (band ratio), image texture analysis (GLCM) and object-based image analysis (OBIA). Among these three approaches, the OBIA showed the best results (section 5.3.4). Indeed, the OBIA allows quantifying the soil aggregate breakdown over time.

When dealing with very high spatial resolution images, the OBIA is a better alternative than a pixel-based one. While the pixel-based approach is based on 
pixels' spectral properties, the OBIA method considers the spectral, spatial, textural, and shape properties of an object. Each object in the image is formed by a group of spatial and spectral homogeneous pixels. These objects can represent real-world features better than the pixels.

Since the OBIA provides similar objects for analysis, it can reduce the local noise and heterogeneity. Moreover, a field sample is more probable to occur in an object than within a single pixel. Therefore, the positional difference between the image and field sample diminishes. Furthermore, the object-based approach allows for image segmentation at various scales (different level of details). The OBIA is a suitable approach in images with large shadow and spectral similarity.

In object-based image analysis, the determination of segmentation parameters is crucial. Setting these segmentation parameters is difficult because they depend on image resolution and the objects of interest on the ground. Therefore, a trial and error process is usually involved in defining these parameters. Among the parameters, scale plays a crucial role in image segmentation. An inappropriate scale might lead to either under or over image segmentation since a homogeneous object in one scale might be heterogeneous at another scale. Consequently, a hierarchical segmentation scale is used to map the different level of details in the image.

Local Binary Pattern (LBP) is a local texture descriptor. The LBP is constructed by comparing a centre pixel with its eight surrounding neighbours in an image. As a result, a binary number is generated that replaces the value of the centre pixel. This LBP value is stored in the output image with the same width and height as the input image. Then the histogram of the LBP image is calculated, which is used as a texture descriptor. To capture details at varying scales, the original LBP is modified by introducing the number of points in a circularly symmetric neighbourhood (not square window) and the radius of the circle, which allows accounting for different scales. Soil aggregates have different sizes, and their shape approximates with a circle. Therefore, it would be interesting to use the LBP texture segmentation to monitor soil aggregates breakdown.

\subsection{Upscaling the proximal sensing data}

Variations in soil stability at a small scale are controlled by the soil properties such as particle size, organic matter content, cation-exchange capacity and soil moisture contents. The study shows that the influence of temperature variations below zero degree Celsius also plays a role. At the field scale, the aggregates of different sizes are joined and held together by bonding the clay particle, polyvalent metal, and organic matter. Moving to the landscape scale, the topography and geomorphic processes also influence soil stability. Furthermore, the climate, soil type, land use and land management practices affect soil stability at the regional scale. Figure 6-1 summarises the controls of soil stability at a different spatial scale. 


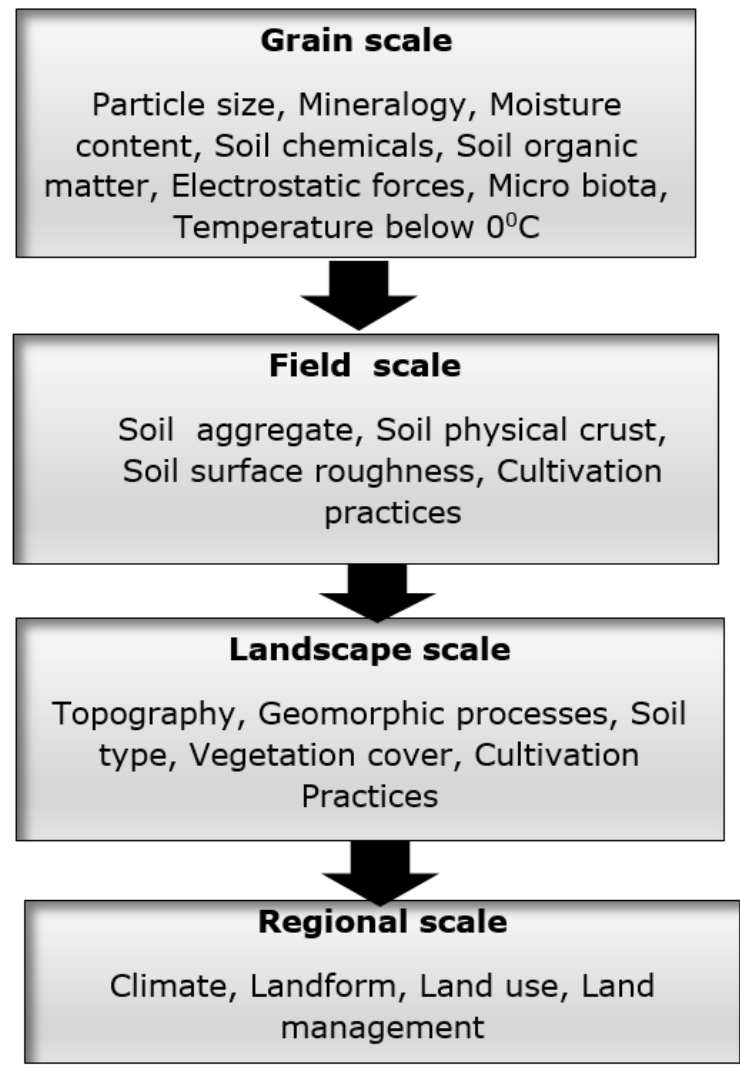

Figure 6-1. Controls of the soil stability at a different spatial scale

Soil stability is a result of complex soil processes and environmental factors. Defining the spatial and temporal scales that represent the soil stability dynamics is difficult. For instance, the small scale variability might be significant in soils. However, the small scale heterogeneity is not well understood because of the effort of data collection. A particular soil process should be analysed at an appropriate spatial and temporal scale. Indeed, it is crucial to know the processes that influence the soil and how they interact at various scales.

The spatial and temporal aspects of the soil processes are closely connected. Since these aspects (spatial and temporal) vary at different scales, they should be considered both at the upscaling approach. In the upscaling approach, the information at one scale might be assumed at another scale. Therefore, the relationships between fine and coarse scales need to be investigated. In the remotely-sensed data, the scale is defined by the image pixel resolution. This image resolution often does not correspond to the scale of the soil processes. Upscaling the high-resolution data to a low resolution leads to the loss of information.

The soil properties' prediction decreases from laboratory to airborne or spaceborne imaging spectroscopy. This decrease in prediction is a result of the 
soil surface characteristics and sensor performance. While the laboratory soil samples are dried and sieved, the natural samples are heterogeneous with variations in the surface temperature, moisture and roughness. Likewise, the sensors are subjected to atmospheric and geometric distortions and lighting conditions. Moreover, they have a low signal to noise ratio, spectral and spatial resolution. The latter might induce pixel mixing problems. The atmospheric correction is crucial in imaging spectroscopy because it affects the spectral signal by increasing the noise. A combination of the empirical and radiative transfer models is used for atmospheric correction. Quantifying the soil properties using image spectroscopy requires the ground truth data for model calibration and validation. Therefore, a correct georeferencing of the image to each soil sample on the ground is needed.

The presence of vegetation cover masks the soil signal. Therefore, image acquisition is performed on bare soil to avoid the loss of the soil signal. Another possibility is to use DEM derivatives, e.g. slope, aspect, wetness index, profile or plan curvatures, to characterise soil.

\subsection{Influence of land cover and climate change}

The interactions of the organo-hydroxide and organo-clay minerals occurring in the soil are the dominant mechanisms for soil stability at the microscale. Depending on the climate conditions, the organic matter interacts with different soil components. In arid and semi-arid areas, the organic matter shows a positive correlation with divalent ions such as calcium and clay minerals. Moreover, organic matter has a strong relationship with Fe and $\mathrm{Al}$ oxyhydroxides in a humid climate. Soil stability is at equilibrium when the soil moisture is at the water holding capacity, and the external factors, climate and land cover changes, are insignificant. However, climate and land cover might have a substantial impact on soil stability.

Due to climate change, prolonged droughts or excessive rain intensity are expected. As a result of heavy and frequent precipitation, the more moisture, the more intense the weathering and leaching processes like the transport of soluble salts, Fe and Al oxides, clay minerals and carbonates. These soil chemical composition changes due to the migration of soil chemical elements negatively affect soil stability. Increasing temperature decreases and increases the soil aggregation in humid and arid environments, respectively. Due to decreasing aggregation, the destabilization of the soil organic matter occurs. Also, high temperatures encourage the mineralization of organic matter. Since soil organic matter is a crucial factor causing cohesion, its decline leads to soil stability weakening. High organic matter occurs in the forest and grassland and less in the agricultural land. As a result, land cover changes will affect soil stability. Deterioration of soil stability directly affects soil degradation processes such as the loss of topsoil due to water or wind, soil fertility depletion due to leaching of nutrients, sealing and crusting due to insufficient protection to the impact of the raindrop.

Agricultural management has changed the soil properties over time. Indeed, the loss of organic matter and minerals alters the natural soil conditions. Therefore, it is crucial to maintain internal soil stability when exposed to external stresses. In soil management, physical stresses are related to tillage 
and compaction. Moreover, the chemical stresses involve fertilizers, which alert the cations and ions composition and chemical bonding.

Unlike conventional agriculture, conservation agriculture follows three principles (i) minimal soil disturbance, (ii) continuous soil cover and (iii) crop rotation (Corsi and Muminjanov, 2019). Conservation agriculture aims to create optimal conditions for crop growth while minimizing environmental degradation. Any natural or human disturbances to the soil top layer lead to changes in soil stability. For example, conventional tillage breaks down the macroaggregates. It enhances the soil organic matter decomposition and decreases microbial activities. In addition, the soil is subject to compaction. Under these conditions, the soil stability will decline to result in soil erosion. Likewise, the drying-wetting, freeze-thaw and biological activities alert the pore size distribution affecting the soil hydraulic properties.

On the contrary, conservation tillage affects soil aggregates and their binding agents positively. Crop residues increase soil organic matter, which leads to soil aggregation. Moreover, the residues protect the soil from raindrop impact, reducing the surface crusting and sealing. Also, the formation of the soil cracks diminishes because the crop residues reduce evaporation. Furthermore, the plant/crop residues decrease the effect of wetting-drying and freeze-thaw on soil aggregate breakdown.

Crop rotations increase organic matter and nitrogen efficiency for plants growth. Likewise, due to crop rotation, the soil microbial activity increases the nutrients available to plants. Moreover, the application of organic manure increases the accumulation and storage of organic carbon in the soil. Also, chemical fertilizers increase the carbon indirectly in the soil through biomass production.

\subsection{Recommendation for further study}

The interactions of the organo-hydroxide, organo-phyllosilicate and phyllosilicate-hydroxide minerals occurring in the soil vary with mineral structure, soil solution, ionic strength and $\mathrm{pH}$. Any alteration of these organomineral interactions due to the moisture variations and freeze-thaw process needs to be identified. Using imaging spectroscopy data on the Silty Loam soil, it is showed that the surface mineralogy changes over time, depending on the soil type, the moisture conditions and freeze-thaw process. Changes in the minerals composition might cause changes in the soil aggregate stability. Therefore, it will be interesting to investigate the effect of these mineralogical changes on soil aggregate stability. Moreover, similar research should be carried on soils in other climatic zones.

\section{The importance of microorganisms on soil aggregation}

Soil aggregation is a result of the physical, chemical and biological processes. While the physical and chemical processes are studied extensively, the biological ones have received less attention. Since these processes might cooccur, it is difficult to determine their contribution to soil aggregation. Soil holds various microbial communities, and the soil microaggregates are considered habitat for microorganisms. The microorganisms bind with mineral 
particles. Also, the microbial remains might act as a glueing agent for microaggregates formation. This description indicates the importance of microorganisms in soil aggregation. However, it needs to be proven. The knowledge of the biological compound binding with different soil minerals is still incomplete. Soil biological activity fluctuates with the seasons. Under extreme temperatures, biological processes slow or stop. Therefore, the temporal dynamics of the biological compounds in soil aggregation remains unknown. Soil biology is difficult to measure due to its diversity. For that reason, finding indirect means for soil biology estimation is an alternative.

\section{Soil porosity influence on soil stability}

Soil porosity controls the storage and movement of water, elements and nutrients in the soil subsurface. Pore size distribution, shape, geometry, and connectivity are essential features to investigate pore space structure changes. Reorganization of soil particles to form aggregates lead to the soil pore space. The soil porosity is affected by the organic matter, Fe and Al oxides and clay present in the soil. Moreover, repeated drying-wetting and freeze-thaw cycles affect the soil pore size distribution. As a result, an increase in the macropores volume leads to organic matter decomposition. These changes will influence soil water retention and hydraulic water conductivity. Therefore, further studies are necessary to investigate pore space's influence on soil stability at various scale from micrometre to centimetre. The hydraulic soil variables need to be measured and modelled to understand the soil water processes at different pore scales. Indeed, with increasing pore scale, the heterogeneity in porous media increases too. Consequently, the behaviour of hydraulic conductivity, water retention and water flow will vary with scale.

\section{The use of multisource remote sensing data for soil surface characterization}

Multisource data should be used to increase the soil classification prediction accuracy and robustness. For example, imaging spectroscopy provides organic and mineral soil spectra data. The X-Ray Fluorescence spectrometry measures the concentration of elements in the soil. Therefore, by combining the data from these sensors, more accurate prediction can be achieved. Soil is a threedimensional matrix. Thus, understanding the soil processes might be improved using the geophysics techniques and the proximal/remote sensing approach. Moreover, proximal sensing and remote sensing should be complementary to each other. In this way, they will provide more useful soil information. Methodologies for upscaling the fine resolution proximal data and downscaling the coarse resolution remote sensing data should be developed. Although imaging spectroscopy is a common approach, still it is a lack of standard protocols for the soil spectra collection.

The Unmanned Aerial Vehicles (UAVs) technology can quantify the soil properties variability at the field scale. Microsensors mounted on the UAVs allowing the acquisition of very high spatial resolution images. Moreover, the same target can be photographed at different altitudes enabling the investigation of the scale issues. Also, due to the flexibility of the flight 
schedule, high temporal resolution data can be obtained. UAVs can carry RGB and hyperspectral cameras. The narrow hyperspectral data will allow us to understand the relations between the soil spectral data and various soil stability processes. Nevertheless, UAVs' use is conditioned by meteorological conditions, the battery life and the maximum payload. Also, some regulations must be followed for the UAV platforms.

\section{Using Mid-infrared for soil properties estimation}

The mid-infrared (MIR) spectroscopy can estimate the physical and chemical soil properties in the laboratory. The fundamental molecular vibrations of the soil components occur in the MIR. Therefore, this portion of the electromagnetic spectrum contains more information on the organic compounds and soil minerals than the NIR and SWIR regions. Moreover, the soil spectra have narrow absorption features defining the soil properties better in the MIR. However, the MIR data analysis might be affected by organic matter, soil moisture, and particle size. These factors can mask the soil absorption features influencing soil spectra behaviour.

\section{The need for soil information}

Previous soil data collection and classification have mainly concentrated on static soil properties. However, the soil is a dynamic system and monitoring its state is crucial. Indeed, soil properties and processes are closely related to soil functioning and ecosystem services. Therefore, our focus should be on better understanding the soil variability to link these variations to land management and environmental, hydrological, agronomic concerns. There is a growing demand for high spatial resolution soil data at the field scale and at the regional, national or continental scale. Likewise, detailed and quantitative soil data should be updated on existing databases. Still, these data are minimal, especially in developing countries. Proximal and remote sensing technology can facilitate the measurements of soil properties in a cost-effective way. Integrating proximal and remote sensing soil data acquired at different spatial scale requires further study to understand better the soil processes. 


\subsection{References}

Corsi, S., Muminjanov, H., 2019. Conservation Agriculture: Training guide for extension agents and farmers in Eastern Europe and Central Asia. Rome,FAO. Kim, K., Chung, H. Y., Ju, J., Kim, J., 2017. Freezing-enhanced reduction of chromate by nitrite. Science of the Total Environment. 590, 107-113.

Qafoku, N.P., 2015. Climate-Change Effects on Soils: Accelerated Weathering, Soil Carbon, and Elemental Cycling. Advances in Agronomy, Vol 131. D. L. Sparks. San Diego, Elsevier Academic Press Inc. 131, 111-172.

Totsche, K.U., Amelung, W., Gerzabek, M.H., Guggenberger, G., Klumpp, E., Knief, C., Lehndorff, E., Mikutta, R., Peth, S., Prechtel, A., Ray, N., KögelKnabner, I., 2018. Microaggregates in soils. Journal of Plant Nutrition and Soil Science. 181(1), 104-13 


\section{Bibliography}

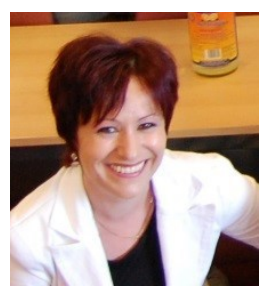

Irena Ymeti was born on 8th October 1979 in Skrapar, Albania. She received the Bachelor degree as a Specialist in Geography, Faculty of History and Philology, University of Tirana, Albania. She completed the Master of Science (MSc) in Water Resources and Environmental Management in 2007 at the Faculty of Geo-Information Science and Earth Observation (ITC), Enschede, The Netherlands. The MSc project that she carried out dealt with rainfall estimation by Remote Sensing for conceptual rainfall-runoff modelling in Ethiopia's Upper Blue Nile basin.

After her MSc graduation, she worked at the national research Institute of Geosciences, Energy, Water and Environment (IGJ EUM) in Tirana, Albania. Her work focused on implementing the Geographic Information Systems and Remote Sensing technology for various applications dealing with natural disasters.

In 2013, she joined the department of Earth Systems Analysis, ITC, the University of Twente, to carry on the PhD research on applied proximal sensing for soil science. She investigated the seasonal effect on the soil surface stability using proximal sensing to better understand the soil aggregation dynamics as a precursor to soil erosion and soil degradation.

During her $\mathrm{PhD}$ research, she attended international conferences to promote her work. She took part in the Wageningen Soil Conference 2015, held $23-27$ August in Wageningen, The Netherlands. She presented a poster entitled "Monitoring soil strength dynamics at plot scale using image texture analysis."

She participated in the SPIE Remote Sensing Symposium, held 26-29 September 2016, in Edinburgh, United Kingdom. She gave an oral presentation entitled "Monitoring soil aggregates dynamics at a plot scale using multitemporal image texture and colour analysis" part of the conference on Earth Resources and Environmental Remote Sensing/GIS Applications.

She was invited as a speaker at the 3rd International Conference and Exhibition on SATELLITE \& SPACE MISSIONS, May 11-13, 2017, Barcelona, Spain. Her oral presentation title was "Using Object-Based I mage Analysis to monitor soil aggregate breakdown under natural conditions".

She was invited as a keynote speaker in the Annual Congress on Soil Sciences, December 04-05, 2017, Madrid, Spain, where she gave the oral presentation "Monitoring the effect of drying-wetting cycles on soil aggregate breakdown using SPECIM hyperspectral camera". She was also an organizing committee member for this conference. 


\section{Author's publications}

Ymeti, I.; Shrestha, D.P.; van der Meer, F. Monitoring Soil Surface Mineralogy at Different Moisture Conditions Using Visible Near-Infrared Spectroscopy Data. Remote Sensing. 2019, 11, 2526

Ymeti, I.; van der Werff, H.; Shrestha, D.P.; Jetten, V.G.; Lievens, C.; van der Meer, F. Using Color, Texture and Object-Based Image Analysis of MultiTemporal Camera Data to Monitor Soil Aggregate Breakdown. Sensors 2017, 17,1241

Ymeti, I.; van der Werff, H.; van der Meer, F; Jetten, V.G. Monitoring soil aggregates dynamics at a plot scale using multi-temporal image texture and colour analysis. SPIE. 2016, 10005-28 
